\title{
Política e identidade cultural na América Latina
}

\author{
José Luís Bendicho Beired \\ Carlos Alberto Sampaio Barbosa \\ (orgs.)
}

BEIRED, JLB., and BARBOSA, CAS., orgs. Política e identidade cultural na América Latina [online]. São Paulo: Editora UNESP; São Paulo: Cultura Acadêmica, 2010. 256 p. ISBN 978-857983-121-8. Available from SciELO Books <http://books.scielo.org>.

\section{(1) (1)(2)}

All the contents of this work, except where otherwise noted, is licensed under a Creative Commons Attribution-Non Commercial-ShareAlike 3.0 Unported.

Todo o conteúdo deste trabalho, exceto quando houver ressalva, é publicado sob a licença Creative Commons Atribuição Uso Não Comercial - Partilha nos Mesmos Termos 3.0 Não adaptada.

Todo el contenido de esta obra, excepto donde se indique lo contrario, está bajo licencia de la licencia Creative Commons Reconocimento-NoComercial-CompartirIgual 3.0 Unported. 


\section{Política \\ E IDENTIDADE CULTURAL NA América Latina}


CONSELHO EDITORIAL ACADÊMICO

Responsável pela publicação desta obra

Áureo Busetto

Carlos Eduardo Jordão Machado

Milton Carlos da Costa

Wilton Carlos Lima da Silva 


\section{JOSÉ LUIS BENDICHO BEIRED CARLOS ALBERTO SAMPAIO BARBOSA \\ (Orgs.)}

\section{Política \\ E IDENTIDADE CULTURAL}

nA América Latina 
(C) 2010 Editora UNESP

\section{Cultura Acadêmica}

Praça da Sé, 108

01001-900 - São Paulo - SP

Tel.: (0xx11) 3242-7171

Fax: (0xx11) 3242-7172

www.editoraunesp.com.br

feu@editora.unesp.br

CIP - Brasil. Catalogação na fonte

Sindicato Nacional dos Editores de Livros, RJ

P829

Política e identidade cultural na América Latina / José Luís Bendicho Beired, Carlos Alberto Sampaio Barbosa (orgs.). - São Paulo : Cultura Acadêmica, 2010.

Inclui bibliografia

ISBN 978-85-7983-121-8

1. Relações culturais. 2. Identidade social - América Latina. 3. Regionalismo - América Latina. 4. Política cultural - América Latina. I. Beired, José Luis Bendicho. II. Barbosa, Carlos Alberto Sampaio.

$11-0145$.

CDD: 306.098

CDU: $316.7(8)$

Este livro é publicado pelo Programa de Publicações Digitais da Pró-Reitoria de Pós-Graduação da Universidade Estadual Paulista "Júlio de Mesquita Filho" (UNESP)

Editora afiliada:

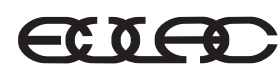

Asociación de Editoriales Universitarias de América Latina y el Caribe

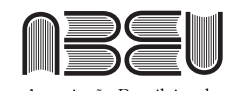

Associação Brasileira de Editoras Universitárias 


\section{SUMÁRIO}

Apresentação 7

Parte I - Intelectuais e identidade cultural 13

1 Iberismo, hispanismo e latino-americanismo no pensamento de Gilberto Freyre: ensaios e impressões de viagens 15 Kátia Gerab Baggio

2 Intelectuais, hispanismo e a reformulação da identidade nacional Argentina 45 José Luis Bendicho Beired

Parte II - Cultura visual e produção de imaginários 67

3 Imaginários políticos no Brasil e no México 69 Carlos Alberto Sampaio Barbosa

4 O Movimento Nacionalista Tacuara e suas ramificações: uma análise de suas representações figurativas 91 Maria Valéria Galván 
5 Imaginários contraculturais na segunda metade do século XX no México: o surgimento do movimento do cinema em Super 8113

Álvaro Vázquez Mantecón

6 Sintonia com o contemporâneo: a TV como objeto e fonte da História 153 Áureo Busetto

Parte III - Processo político e relações internacionais no Cone Sul 177

7 Brasil e Argentina: uma análise comparativa das políticas econômicas no contexto da Grande Depressão dos anos 1930179

Francisco Luiz Corsi

8 A questão do consenso durante a ditadura militar argentina: problemas metodológicos e contextos historiográficos (1976-1983) 201

\section{Daniel Lvovich}

9 A oposição de direita ao populismo no Cone Sul: proposta para uma história latino-americana e comparativa 221

\section{Ernesto Bohoslavsky}

10 Argentina e Brasil em marcha para a integração (1950-1962) 233

$$
\text { luri Cavlak }
$$

Dados dos autores 255 


\section{ApresentaÇÃo}

A formação de redes interuniversitárias tem sido uma meta perseguida tanto pelas instituições de Ensino Superior quanto pelos agentes diretamente envolvidos, isto é, os próprios professores. Nos últimos anos, as experiências com as universidades latino-americanas têm sido especialmente fecundas, estimuladas tanto pela proximidade geográfica quanto pela identificação de problemas e necessidades comuns.

Este livro constitui um dos resultados dessa agenda de interesses comuns, concretizada mediante um programa de cooperação entre a Universidade Estadual Paulista "Júlio de Mesquita Filho" e a Universidade Nacional de General Sarmiento, da Argentina. Gestado a partir de intercâmbios acadêmicos entre historiadores de quatro universidades latino-americanas, a iniciativa tem buscado desenvolver a internacionalização da pós-graduação mediante a promoção de diversas ações, tais como intercâmbio de professores e estudantes, realização de pesquisas, promoção de eventos e edição de publicações científicas. Em termos gerais, a preocupação reside em consolidar uma série de redes já existentes, formadas por historiadores do Brasil da Argentina, do Chile e do México, e que têm em comum a preocupação com problemas políticos e culturais contemporâneos. Busca-se, dessa forma, consolidar redes que se 
convertam em uma plataforma que respalde novos projetos de formação e de investigação de âmbito latino-americano.

No livro reunimos uma seleção dos trabalhos apresentados no primeiro seminário do programa, realizado em 2008. Eles estão centrados em dois grandes eixos temáticos: as identidades culturais e a política latino-americana durante o século XX. A identidade é um conceito que foi objeto de inúmeras reflexões por parte das ciências humanas com o objetivo de definir seu significado e sua funcionalidade, assim como de apontar suas limitações. Do ponto de vista da disciplina histórica, importa assinalar que as identidades não são aqui entendidas como essências ou entidades imutáveis, mas como processos incessantes de construção/reconstrução dos imaginários sociais. Multidimensionais, as identidades coletivas possuem não apenas componentes sociais e culturais, mas também políticos, uma vez que refletem, induzem e justificam as ações humanas sobre as relações de poder.

A identidade constitui uma projeção, quer do sujeito individual em relação ao mundo exterior, quer de um sujeito coletivo em relação a um contexto social mais amplo. Do ponto de vista individual, a identidade é o resultado da articulação entre o sujeito e a estrutura da sociedade mediante um processo em que a projeção do "eu" sobre as identidades coletivas conduz à internalização de valores e comportamentos que se tornam parte da subjetividade de cada um.

Por sua vez, as identidades coletivas também são objeto de construção e reformulação ao longo do tempo. Como demonstrado pelos estudiosos, o nacionalismo foi um importante vetor da construção das identidades coletivas no mundo contemporâneo. Para isso, os governos pressionaram os indivíduos a abandonar as lealdades locais e regionais em favor da lealdade à nação por meio da educação, dos rituais cívicos e da política de massas. Evidentemente, a homogeneização do processo de nacionalização da coletividade não foi total e conviveu com questionamentos até o momento vigentes em diversas partes do mundo, incluindo a América Latina. Além disso, no interior de cada sociedade existe uma sobreposição de identidades, e nesse sentido podemos encontrar diversas identida- 
des políticas, étnicas e culturais convivendo simultaneamente de forma mais ou menos contraditória e, frequentemente, competindo entre si pela conquista da hegemonia.

Como o leitor poderá apreciar, o problema da identidade cultural é abordado por diversos ângulos, notadamente no exame das representações da nação e da América Latina, da produção artística e dos meios de comunicação de massa. Inclusive o espaço internacional mostra-se como um lugar de construção das identidades culturais, uma vez que elas também se forjam em função das relações entre as nações, isto é, no contato com o "outro". É na relação com o outro que são estabelecidas as especificidades políticas e culturais, a diplomacia e, inclusive, os interesses econômicos, em suma, os elementos de diferenciação dos países em relação aos demais atores da vida internacional que permitem construir a representação da identidade coletiva de um país.

No entanto a questão da identidade cultural não se encontra isolada de outros domínios da realidade, ao contrário, está vinculada à vida política. Nos artigos aqui presentes, a política é concebida não apenas em sua dimensão institucional, mas em um sentido amplo, como assinalado por René Rémond, enquanto esfera que se comunica com diversos âmbitos da realidade, da cultura à sociedade, da economia às relações internacionais. Nesse sentido, o tratamento conferido à política nos artigos remete tanto ao processo político quanto às culturas políticas e às identidades culturais. Por exemplo, o nacionalismo, o latino-americanismo e o hispanismo são componentes da identidade cultural que não podem ser compreendidos desligados da vida política. Além disso, a cultura política, entendida como sistema de representações portadoras de normas e valores políticos, encontra-se intimamente interligada a fenômenos tais como o autoritarismo, a democracia, o populismo e, mais uma vez, o nacionalismo.

Os textos deste volume encontram-se organizados em três partes: "Intelectuais e identidade cultural"; "Cultura visual e produção de imaginários"; "Processo político e relações internacionais no Cone Sul”. Na primeira parte, Kátia Baggio e José Luis Bei- 
red debruçam-se sobre como o problema da identidade cultural das nações latino-americanas foi enfrentado por um conjunto de intelectuais. Kátia Baggio analisa como o problema da tradição ibérica desempenha um papel central na obra de Gilberto Freyre e como suas reflexões foram pautadas pelo diálogo com os intelectuais espanhóis. Em contraponto à modernidade ocidental e, em especial, ao padrão cultural da sociedade norte-americana, Freyre defendia uma tese polêmica do ponto de vista brasileiro, qual seja, a existência de uma singular "cultura transnacional pan-hispânica", que incluía tanto o Brasil quanto a Península Ibérica. O problema das raízes ibéricas é retomado no ensaio de José Luis Beired, ao examinar a revalorização da herança espanhola pelos intelectuais argentinos do início do século XX. O autor discute como uma nova atitude política e cultural diante da Espanha repercutiu na reelaboração da identidade nacional argentina e acabou por fortalecer a corrente criollista: do predomínio do anti-hispanismo no século XIX passou-se à exaltação da Espanha, à revisão da memória e à busca da aproximação entre os dois lados do Atlântico.

O bloco "Cultura visual e produção de imaginários" reúne reflexões que possuem como denominador comum a relação entre a cultura visual e a construção de identidades e imaginários sociais e políticos na América Latina do século XX. O trabalho de Carlos Alberto S. Barbosa mapeia a circulação de projetos políticos, estéticos e a constituição de repertórios de imagens de cunho político presentes nas sociedades brasileiras e mexicanas na primeira metade do século XX. Já a pesquisadora argentina Valéria Galván busca averiguar os imaginários sociais e a elaboração de identidades presentes no movimento Tacuara entre os anos 1960 e 1970. Procura interpretar, em especial, as imagens e os símbolos estampados nas diversas publicações desses grupos nacionalistas argentinos. No terceiro texto, o mexicano Álvaro Mantecón reflete sobre a noção de contracultura nas sociedades subalternas e a construção de um novo imaginário presente nas narrativas fílmicas da juventude mexicana após 1968, expressa na produção de filmes em Super 8. Por fim, Áureo Busetto faz uma instigante reflexão sobre os estudos 
históricos relacionados à televisão, em especial a televisão brasileira. Ele realiza um minucioso panorama da historiografia referente às investigações sobre a utilização da televisão como fonte e objeto da História e propõe possibilidades de pesquisas sobre essa mídia, hoje tão onipresente na vida cotidiana e ao mesmo tempo tão carente de estudos sistemáticos.

$\mathrm{Na}$ terceira seção são tratados temas que envolvem o processo político e as relações internacionais no Cone Sul. O historiador Daniel Lvovich pergunta-se sobre os fundamentos do consenso político do regime militar argentino iniciado em 1976. Tomando como referência as discussões da historiografia sobre a construção do consenso nos fascismos europeus e nos regimes militares chileno e uruguaio, procura analisar como as diversas esferas da sociedade argentina reagiram ao chamado Processo de Reorganização Nacional. Além de examinar as reações das grandes organizações, tais como os partidos e os sindicatos, oferece elementos para refletir sobre o grau de cumplicidade e de apoio da parte não organizada da sociedade, isto é, da maior parte da população argentina àquele regime: até que ponto isso não teria ficado encoberto pelos artifícios da memória social?

No capítulo seguinte o problema da oposição aos populismos é discutido por Ernesto Bohoslavsky mediante o estudo comparativo de processos situados em três países: Argentina, Brasil e Chile. O autor considera insuficientes os aportes da historiografia aos movimentos de oposição ao populismo e entende que dois movimentos analíticos devem ser desenvolvidos para o estudo dos partidos antipopulistas em perspectiva latino-americana: a análise de suas representações ideológicas e das relações com as forças armadas.

Os dois próximos artigos debruçam-se sobre duas questões muito atuais: a superação da Crise de 1929 e a integração entre o Brasil e a Argentina. Francisco Corsi compara as diferentes respostas dessas nações à depressão dos anos 1930 por meio de uma minuciosa análise da realidade econômica dos dois países e de sua inserção no sistema econômico internacional. $\mathrm{O}$ autor examina a hipótese de que as diferentes estratégias elaboradas por cada país 
para a superação da crise foram a tal ponto decisivas que acabaram por condicionar o desenvolvimento econômico das décadas seguintes. Até que ponto as diferentes respostas da atual depressão não guardam relação com as experiências anteriores?

A possibilidade de integração dos dois países nos anos 1950 e 1960 é o objeto do artigo de Iuri Cavlak. Por um lado, o autor centra o foco sobre os movimentos de aproximação ensaiados pelos governos de ambos os países, e por outro, apresenta os obstáculos que se interpuseram: a resistência dos Estados Unidos e os próprios problemas políticos internos do Brasil e da Argentina, que acabaram por levar à derrocada dos presidentes empenhados na aproximação, Arturo Frondizi e João Goulart.

Por fim, agradecemos o apoio da pró-reitoria de Pós-Graduação da Unesp, que colaborou com o financiamento do seminário em que os trabalhos deste livro foram apresentados e com a tradução dos textos em espanhol. 
PARTE I

INTELECTUAIS E IDENTIDADE CULTURAL 



\title{
1 \\ IBERISMO, HISPANISMO \\ E LATINO-AMERICANISMO \\ No PENSAMENTO dE GILBERTO FreYRe: ENSAIOS E IMPRESSÕES DE VIAGENS
}

\author{
Kátia Gerab Baggio ${ }^{1}$
}

Ainda que constituam uma parte minoritária da obra do escritor, sociólogo, antropólogo e historiador pernambucano Gilberto Freyre (Recife, 1900-1987), suas reflexões sobre temas como iberismo, hispanismo, latino-americanismo, relações entre as Américas e diversidade cultural do continente estão fortemente relacionadas e imbricadas às suas interpretações sobre a formação social e cultural do Brasil. Além disso, as concepções freyrianas sobre o que ele mesmo denominou, a partir dos anos 1950, como lusotropicologia e hispanotropicologia estão diretamente ligadas às referências ibéricas de seu pensamento. O próprio Freyre designou-se como um intelectual iberista, tanto herdeiro como defensor das tradições

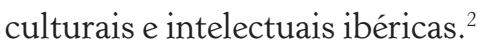

Antes de entrar propriamente nas reflexões freyrianas sobre temas relacionados ao iberismo e ao latino-americanismo, considero importante fazer algumas breves considerações sobre as referências

1 Doutora e docente da UFMG, é autora de A questão nacional em Porto Rico O Partido Nacionalista (1922-1954), São Paulo: Annablume, 1998 e coautora de A rebelião de Tupac Amaru. São Paulo: Brasiliense, 1987.

2 Entre as obras de Gilberto Freyre em que esses temas aparecem de maneira mais explícita, ver Freyre (1975; 1941b). Sobre o iberismo e hispanismo na obra de Freyre, ver Bastos (2003) e Crespo (2003, p.181-204). 
teórico-metodológicas de Freyre e acerca da recepção de sua obra, a fim de situar melhor esses textos em seu conjunto.

Autor de clássicos como Casa-grande E senzala (1933), Sobrados e mucambos (1936), Nordeste (1937), entre outros, Freyre inspirou, desde suas primeiras obras, intensas e agudas polêmicas. Foi duramente criticado pelos mais conservadores, nos anos $1930 \mathrm{e}$ 1940, devido ao protagonismo dos anônimos em sua obra, ao elogio do popular, à celebração da mestiçagem étnica e cultural, à linguagem coloquial e explícita - "chula" e "obscena", para muitos - e à abordagem sobre os hábitos sexuais e a vida íntima no Brasil no período colonial e no século XIX. Ao mesmo tempo, celebrizou-se, em geral, pela mesma razão que levou parte dos críticos a rejeitá-lo: a interpretação da formação sociocultural brasileira fundada nas relações, um tanto ambíguas, entre senhores e escravos, entre brancos, negros, indígenas, mulatos e caboclos, dentro de uma sociedade mestiça de profundos traços patriarcais e autoritários. ${ }^{3}$

A partir dos anos 1950, a recepção à obra de Freyre começou a alterar-se. Nas duas décadas anteriores, como já mencionado, a autor pernambucano foi rejeitado pelos conservadores e valorizado pelos intelectuais críticos das concepções deterministas, racialistas e racistas, herdadas do século XIX. Inclusive, foi louvado por muitos intelectuais de esquerda, como Astrojildo Pereira, Jorge Amado, entre outros. Na década de 1950, entretanto, Freyre começou a receber críticas agudas da intelectualidade de esquerda e centro-esquerda. Suas aproximações, cada vez mais explícitas, das

3 Como se sabe, há uma extensa bibliografia sobre a obra de Gilberto Freyre. Optei por citar aqui apenas os autores que me auxiliaram mais diretamente na feitura deste texto. Além dos trabalhos já referidos na nota anterior, ver Ribeiro (2000, p.11-42) (este texto de Darcy Ribeiro foi publicado como prólogo à edição de Casa-grande E senzala pela Biblioteca Ayacucho, Caracas, Venezuela, 1977; na 1 a edição brasileira do livro, o subtítulo aparece como: "Formação da família brasileira sob o regime de economia patriarcal”), Araújo (2005), os ensaios reunidos em Kosminsky et al. (2003), Pallares-Burke (2005, p.39-41), Nicollazzi (2006, p.240-65) e Mailhe (2008, p.331-55). Entre as obras recentes publicadas sobre Freyre, também merece destaque Larreta \& Giucci (2007). 
concepções políticas de direita, além de formulações discutíveis e problemáticas - como o lusotropicalismo, o hispanotropicalismo e a tropicologia -, explicam, em grande medida, a recusa à obra de Freyre por parte da maioria dos jovens intelectuais que iniciavam suas carreiras e sua produção nos agitados anos 1960.

De agosto de 1951 a fevereiro de 1952, Freyre fez uma longa viagem por Portugal e colônias portuguesas na África e Ásia (Goa). Em sua viagem, o intelectual brasileiro manifestou apoio ao regime ditatorial português, comandado por António de Oliveira Salazar, e à política colonialista portuguesa. ${ }^{4} \mathrm{Na}$ década seguinte, alinhou-se com aqueles que apoiaram a ditadura militar no Brasil. ${ }^{5} \mathrm{O}$ iberismo de Freyre, sua defesa das tradições culturais e intelectuais herdadas de Portugal e Espanha, além de sua inegável nostalgia em relação ao passado patriarcal, o transformaram na imagem mais evidente de intelectual representante dos valores de um Brasil rural, oligárquico e patrimonialista que se queria superar. Ademais, as frequentes manifestações de celebração de si próprio e de sua obra, os autoelogios reiterados, evidências de sua imensa vaidade, reforçaram a crescente rejeição à figura e à obra de Freyre nos anos 1960 e 1970, décadas - a partir do golpe militar de 1964 que derrubou o presidente João Goulart - de governos ditatoriais e repressivos, apoiados por Freyre. ${ }^{6}$

A partir da década de 1980, sob os efeitos do fortalecimento da história cultural e sociocultural e do desgaste das concepções

4 Freyre relatou a viagem em livro cujos título e subtítulo são reveladores: Freyre (2001). Para uma perspectiva crítica sobre a viagem de Freyre e seu livro Aventura e rotina, ver Mailhe (2008; 2006).

5 Gilberto Freyre integrou o Conselho Federal de Cultura, a convite do presidente Emílio Garrastazu Médici e do ministro da Educação Jarbas Passarinho, durante o período mais repressivo do regime militar brasileiro. Além disso, "por decisão do presidente Médici”, foi reconduzido ao Conselho Diretor do Instituto Joaquim Nabuco. Ver "Nota da Editora”. In: FREYRE, G. O brasileiro entre os outros hispanos. Rio de Janeiro: José Olympio; Brasília: INLMEC, 1975, p.17.

6 Ver Costa Lima (2003, p.9-13) e Skidmore (2003, p.41-64). 
marxistas, a obra de Gilberto Freyre começou a ser fortemente revalorizada. Suas análises sobre a diversidade cultural brasileira, a vida cotidiana, a intimidade, os hábitos alimentares, as expressões culturais populares (danças, músicas, festas), além do elogio à miscigenação étnica e cultural, ao viés antropológico e ao uso da história oral, levou a obra de Freyre - principalmente seus livros e textos publicados nos anos 1930 - a uma nova recepção, nas últimas décadas, particularmente pelos pesquisadores vinculados à perspectiva da História Social da Cultura. Del Priore (2002, p.19) assim se refere à obra de Freyre:

A presença de tais temas [a casa, o corpo] na obra freyriana dão a medida de sua incrível atualidade, de sua capacidade de anteciparse ao próprio tempo e avançar novas abordagens e novos objetos.

E mais adiante, no mesmo texto:

Crítico das interpretações rasteiras que identificavam as tensões culturais às "lutas de classes", Freyre é observador arguto dessa que Roger Chartier denominou, bem mais tarde, luta de representações. (idem, p.22)

Ou seja, a recepção da obra de Freyre foi pautada por leituras díspares, mais ou menos marcadas pelas imbricações entre a obra e as concepções e filiações políticas do autor pernambucano. Depois de sofrer forte rejeição, Freyre passou a ser revisitado com frequência. Entre os trabalhos que reavaliaram sua obra, um dos mais significativos é o de Ricardo Benzaquen de Araújo, publicado em 1994. O autor mostra, entre outras questões, que em Casa-grande $\mathcal{E}$ senzala a defesa da ideia da convivência, adaptação e tolerância entre senhores e escravos, própria, segundo Freyre, das formas adquiridas pela colonização portuguesa nos trópicos - que ensejaram algumas das críticas mais agudas à obra freyriana, relacionadas à defesa, por parte do autor pernambucano, de uma suposta "brandura" e "harmonia" nas relações sociais e raciais no Brasil -, 
cede espaço também, no mesmo livro, a numerosas referências à violência que permeava as relações escravistas no país. Ainda que a tese da miscigenação como promotora da "democratização social no Brasil”" seja defendida ao longo da obra, Freyre abre e fecha Casa-grande $\mathcal{E}$ senzala com referências à violência e ao sadismo dos senhores em suas relações com os escravos:

Sem deixarem de ser relações - as dos brancos com as mulheres de cor - de "superiores" com "inferiores" e, no maior número de casos, de senhores desabusados e sádicos com escravas passivas, adoçaram-se, entretanto, com a necessidade experimentada por muitos colonos de constituírem família dentro dessas circunstâncias e sobre essa base. (Freyre, 2000, p.46)

Mais adiante, no mesmo prefácio, Freyre, a partir de documentos relacionados à visitação do Santo Ofício ao Brasil, faz menção a "senhores mandando queimar vivas, em fornalhas de engenho, escravas prenhes, as crianças estourando ao calor das chamas" (idem, p.57).

Além de outras passagens impactantes como a anterior, Freyre termina seu livro, no último parágrafo - depois de dissertar sobre os cânticos e as festas dos negros -, com as seguintes considerações:

Mas não foi toda de alegria a vida dos negros, escravos dos ioiôs e das iaiás brancas. Houve os que se suicidaram comendo terra, enforcando-se, envenenando-se com ervas e potagens dos mandingueiros. O banzo deu cabo de muitos. O banzo - a saudade da África. (idem, p.514)

Ainda assim, apesar de iniciar e encerrar Casa-grande E' senzala mencionando as torturas, a violência e a tristeza dos negros escravizados, prevalece a ideia, na obra, de que as relações raciais no Brasil teriam sido mais brandas do que em outros países, particularmente nos Estados Unidos, em conformidade com a concepção de Freyre sobre os "antagonismos em equilíbrio". A expressão de Freyre diz 
tudo: os antagonismos da sociedade patriarcal e escravista estavam, segundo o autor pernambucano, em equilíbrio. Portanto, não seriam plenamente adequadas as interpretações que priorizassem os conflitos sociais, raciais, culturais, econômicos, políticos etc.

As concepções freyrianas, inclusive a ideia dos "antagonismos em equilíbrio", tiveram inspiração múltipla. Em sua trajetória, Freyre recebeu e incorporou, de maneira seletiva, uma série de referências teórico-metodológicas, diversas e, em muitos casos, conflitantes. $\mathrm{O}$ autor pernambucano apropriou-se, de maneira mais ou menos explícita, de várias dessas referências e reflexões, adequando-as aos seus propósitos interpretativos acerca das "especificidades" da formação sociocultural brasileira.

Ainda muito jovem, com 18 anos incompletos, no início de 1918, partiu para os Estados Unidos e matriculou-se na Baylor University, em Waco, Texas. A guerra na Europa impediu Freyre, nesse momento, de seguir seus estudos em instituições europeias, como pretendia. Nessa época, aprofundou-se em leituras de ensaístas, filósofos, historiadores, cientistas sociais, viajantes, naturalistas, romancistas e poetas norte-americanos, ingleses, franceses, espanhóis, alemães etc., além de ler e reler autores brasileiros. Após concluir o bacharelado em Artes, em Baylor, seguiu para Nova Iorque e ingressou na Columbia University, onde aprofundou sua formação intelectual. Em Columbia, foi aluno de professores que marcariam sua obra, como o antropólogo Franz Boas, sobre o qual declarou, no prefácio à Casa-grande É senzala: "é a figura de mestre de que me ficou até hoje maior impressão”. E, acerca do impacto das ideias de Boas em sua própria obra, confessou:

Foi o estudo de Antropologia sob a orientação do Professor Boas que primeiro me revelou o negro e o mulato no seu justo valor - separados dos traços de raça os efeitos do ambiente ou da experiência cultural. Aprendi a considerar fundamental a diferença entre raça e cultura; a discriminar entre os efeitos de relações puramente genéticas e os de influências sociais, de herança cultural e de meio. (idem, p.45, destaques no original) 
Após concluir os estudos em Nova Iorque, em 1922, seguiu para a Europa, um velho sonho. Visitou a França, a Alemanha, a Bélgica, a Espanha e Portugal. Esteve na Inglaterra, demorando-se em Oxford.

Ao esquadrinhar os referenciais anglo-americanos, particularmente os britânicos, da obra e das ideias de Freyre - a partir de seu período como estudante nos Estados Unidos e na Inglaterra -, Pallares-Burke (2005) enfatiza que, ao lado de autores consagrados em seu tempo, como Herbert Spencer e Franz Boas, Freyre buscou inspiração em autores considerados "menores" e em "obras obscuras", como as dos irmãos Goncourt, franceses, ou os ensaios e narrativas de viagens de Lafcadio Hearn, de ascendência irlandesa e grega. Pallares-Burke (idem, p.12) pretende evidenciar "a importância dos autores britânicos, especialmente do período vitoriano, para o desenvolvimento intelectual de Gilberto Freyre", ainda que admita, também, a grande relevância de autores franceses, alemães, espanhóis, portugueses, norte-americanos e, também, brasileiros.

A concepção freyriana de "equilíbrio de antagonismos", fundamental em sua obra, teria sido inspirada, de acordo com PallaresBurke (idem, p.41), pela leitura de intelectuais britânicos, como o escocês Thomas Carlyle e os ingleses Herbert Spencer e Alfred Zimmern, além do norte-americano Franklin H. Giddings. Além desses autores, a autora menciona, entre as referências importantes para Freyre, G. K. Chesterton, Arnold Bennett, Walter Pater, Gissing, George Moore, Havelock Ellis, entre outros. Chesterton e Hearn rejeitaram a ideia de uma Inglaterra formada por uma "raça pura". Lafcadio Hearn viveu no Japão, nos Estados Unidos radicando-se em New Orleans - e nas Antilhas Francesas, de onde fez elogios intensos à mestiçagem, exaltando a beleza, a força, a alegria, a música, a dança, a linguagem e a culinária de negros e mulatos antilhanos. O impacto da obra de Spencer - autor consagrado em fins do século XIX e no início do século XX - sobre o escritor pernambucano teria sido, segundo a autora, "decisivo". Em Spencer, Freyre admirava sobretudo a moderação e o "equilíbrio intelectual”, avesso a posições extremadas. Segundo Pallares-Burke 
(idem), a expressão "antagonismos em equilíbrio", tão frequente na obra de Freyre, foi por ele encontrada em um texto de Thomas Carlyle e reencontrada em Herbert Spencer. A busca pela harmonização de concepções antagônicas e a ideia da "relatividade de todo conhecimento", presentes em Spencer, teriam inspirado Freyre a ver, no Brasil, a mesma tendência conciliadora que o filósofo inglês enxergava em seu país. Em conferência ministrada em Belo Horizonte, em 1946 - ou seja, logo após o fim do Estado Novo varguista -, Freyre (1965, p.111-2) identificou Minas Gerais como a "nossa Grã-Bretanha" e considerou mineiros e baianos "conciliadores por excelência”, cientes das contradições inerentes à natureza humana. Segundo a perspectiva de Freyre (1989, p.112),

[... nem a monocultura, nem o latifúndio, nem a escravidão, que condicionaram de modo tão decisivo o desenvolvimento social do Brasil [...] merecem condenação formal de quem se aproxime do assunto sob o critério do relativo. E não do absoluto, tão perigoso nas avaliações sociais. Tão perturbador da perspectiva histórica.

Há, nessa passagem, ao celebrar o relativismo, uma evidente despolitização dos problemas socioeconômicos do Brasil, aliada à concepção freyriana de exaltação da conciliação. Algumas interpretações recentes sobre a obra de Freyre, de viés culturalista, se, por um lado, buscam revalorizar suas evidentes contribuições para a história sociocultural do Brasil, por outro, reforçam essa visão despolitizada da vida colonial e imperial brasileira, diluindo os conflitos e disputas - em nome das convergências e "antagonismos em equilíbrio" - e ignorando as críticas anteriormente recebidas por Freyre em razão de sua visão enaltecedora dos trópicos como espaço, por excelência, da conciliação.

Emrelaçãoàs dívidasintelectuais deFreyre paracomo pensamento anglo-saxônico, e britânico em particular, ainda que estas sejam inegáveis - como Pallares-Burke (2005) demonstra com erudição e competência -, não podem minimizar a relevância de outras referências intelectuais presentes na obra do sociólogo pernambucano. 
Bastos (2003) analisou as contribuições de importantes autores espanhóis para a formação intelectual e o pensamento de Freyre. A autora mostrou, com clareza, que muitas das ideias freyrianas sobre a formação social e cultural brasileira tiveram inspiração em fontes espanholas. Durante os anos em que viveu e estudou nos Estados Unidos e na Europa, entre 1918 e 1923, o autor brasileiro teve contato com a obra de importantes intelectuais espanhóis, tanto da chamada geração de 1898 como da posterior, de 1914. As referências espanholas mais constantes de Freyre foram Ángel Ganivet, ${ }^{7}$ Joaquín Costa, Miguel de Unamuno, Pío Baroja, José Ortega y Gasset, Américo Castro e Julián Marías. Vale destacar também que, em Nova Iorque, Freyre manteve frequentes conversas com o espanhol Federico de Onís, professor de literatura espanhola e hispano-americana na Columbia University. ${ }^{8}$

Como assinalou Bastos (idem, p.7-12), Freyre endossou, nesses autores, algumas concepções que permeiam grande parte de sua obra. Entre elas, a defesa do retorno às tradições e a valorização do regional e do popular, além da "afirmação do encontro de elementos orientais e ocidentais" na formação ibérica, e, por extensão, ibero-americana e brasileira.

Referindo-se ao granadino Ángel Ganivet, Freyre (1975, p.168) chegou a afirmar: "ele me ajuda a ver o Brasil como ninguém". Bastos (2003) chama a atenção para o grifo, feito por Freyre, em trecho do prólogo a Idearium español, livro de Ganivet de 1897, assinado pelo escritor Cristóbal de Castro (1987, p.8-9) - andaluz como Ganivet, mas nascido no sul da província de Córdoba:

[Ganivet] não percebe o povo como político, mas como artista. Por exemplo, o sufrágio universal o indigna, como a um duque inglês ou a um bispo espanhol. Em contrapartida, os cantos populares o embriagam, como a um cigano ou a um "flamenco".

7 Ángel Ganivet pode ser considerado um antecessor da geração de 1898, já que se suicidou em novembro desse mesmo ano, aos 33 anos.

8 Livros e textos de vários desses autores podem ser encontrados na biblioteca de Gilberto Freyre. Ver Bastos (2003, p.36). 
E assinalando palavras de Ganivet:

Meu instinto me arrasta ao comum, ou melhor, ao popular, ao que agrada e interessa ao povo [...].(ibidem)

Não há dúvida de que essa percepção do "povo" e do "popular" encontra-se constantemente presente na obra de Freyre, desde suas reflexões iniciais. Em texto de 1923, ao comentar palavras do escritor brasileiro Agripino Grieco, afirmou:

[...] Do ideal de alfabetismo escrevi que o resultado era a mediania de cultura. [...] Da instrução universal resultam as Suíças, as Finlândias e o muito que têm de "bon enfant" os Estados Unidos. Democracias de cidadãos lavados, barbeados e bem penteados, irritantemente parecidos uns aos outros, medianos em tudo. [...] No artigo do Sr. Agripino Grieco [...] vêm ideias parecidas a estas. [...] Muito justo me parece o íntimo parentesco que entre os daninhos ideais de "sufrágio universal" e "instrução universal" estabelece o Sr. Grieco. (Freyre, 1979, p.305-6)

Fica claro nessa passagem que, para Freyre, a escolarização vinculada, no texto, ao ideal de sufrágio universal - levaria a uma vulgarização e homogeneização da cultura popular, eliminando, aos poucos, expressões culturais populares regionais e "autênticas". A modernização viria, inevitavelmente, em contraposição à manutenção das tradições. Nesse sentido, Freyre expressa, como em muitas outras ocasiões, seu antiliberalismo. Para ele, o "atraso" tinha inúmeras vantagens, já que a modernização a tudo uniformizava. Segundo Freyre, o ideário liberal aplicado ao Brasil era "falso", "artificial", desconectado das "autênticas" raízes culturais brasileiras: ibéricas, africanas e ameríndias.

Em Ortega y Gasset aparece, também, desde seu primeiro livro Meditaciones del Quijote (1914) -, a concepção de que, na Espanha, o racionalismo burguês não havia fincado raízes. E as ideias de Freyre, relacionadas à bicontinentalidade do mundo ibérico - ao 
mesmo tempo europeu e africano, europeu e árabe - e a um suposto sensualismo no caráter peninsular, resultado do encontro entre tradições culturais ocidentais e orientais, têm, claramente, inspiração em concepções de Ortega y Gasset. ${ }^{9}$ Para Freyre, a modernização operada a partir do século XIX, no Brasil, teria levado a uma crise dos valores da sociedade patriarcal e de seu significado como mantenedora dos "antagonismos em equilíbrio". Também em Ortega y Gasset aparece a ideia de "tempo tríbio", de forte e constante presença na obra de Gilberto Freyre. ${ }^{10}$ Mas, diversamente de Ortega, Freyre não aceitava a abertura para o processo de modernização, tal qual ele se manifestava no Brasil. Nesse sentido, o sociólogo brasileiro aproximava-se de Unamuno, para quem a Espanha deveria, para superar a crise, alimentar-se da cultura popular e de suas próprias tradições. Assim também pensava Freyre: o Brasil deveria manter as tradições culturais herdadas do período colonial para seguir adiante. Sua perda levaria à decadência, tal qual acontecia na Espanha. ${ }^{11}$ Sobre o iberismo, o hispanismo e o latino-americanismo na obra de Freyre, cabe mencionar os artigos em jornais brasileiros e argentinos publicados pelo sociólogo pernambucano por ocasião de sua viagem aos países platinos, no início dos anos 1940. Suas breves

$9 \mathrm{Na}$ América Latina, o pensamento de José Ortega y Gasset difundiu-se com muita força desde a década de 1920. Ortega y Gasset esteve por três vezes na Argentina, ocasiões em que divulgou suas ideias a partir do país platino: de 1916 a 1917, de 1928 a 1929 e, pela terceira vez, de 1939 a 1942 (coincidindo com o período em que Freyre esteve no país vizinho). Nos anos 1940 e 1950, pensadores espanhóis exilados no México, como José Gaos, além de intelectuais mexicanos, como Samuel Ramos e Leopoldo Zea, entre outros, também contribuíram significativamente para incrementar a disseminação das ideias orteguianas pelo continente.

10 O "tempo tríbio", segundo Freyre, seria uma "singularidade no sentido hispânico de tempo", em que "presente, passado e futuro" seriam "aspectos de uma mesma fluência de vida” e não poderiam ser arbitrariamente separados. Ou seja, não se poderia romper com o passado e com as tradições. Cf. Freyre (1975, p.47).

11 As considerações aqui desenvolvidas sobre as leituras freyrianas dos filósofos e escritores espanhóis são devedoras das análises de Bastos (2003) e Crespo (2003, p.181-204). 
impressões da viagem pelo Uruguai, pela Argentina e pelo Paraguai são textos bem menos conhecidos e visitados de sua vasta obra, mas nem por isso desinteressantes. Esses textos foram escritos em Montevidéu, em Buenos Aires e em Assunção, entre dezembro de 1941 e fevereiro de 1942, em razão da viagem de lua de mel de Gilberto Freyre e de sua esposa, Maria Magdalena, pela região, estada que coincidiu com a publicação de Casa-grande E senzala na Argentina, a primeira edição estrangeira do clássico freyriano. ${ }^{12}$

Os artigos escritos por ocasião da viagem foram publicados nos jornais La Nación, de Buenos Aires; Correio da Manhã, A Manhã e Diário de Notícias, do Rio de Janeiro; Jornal do Commercio e Diário de Pernambuco, do Recife. Alguns textos são posteriores à volta de Freyre ao Brasil. ${ }^{13} \mathrm{E}$ como um dos resultados dessa visita à Argentina, Freyre tornou-se colaborador do La Nación, um dos mais importantes diários de Buenos Aires. ${ }^{14}$ A viagem foi financiada par-

12 Freyre (1942). No ano seguinte, também na Argentina, foi publicado outro clássico do autor: Nordeste: aspectos de la influencia de la caña sobre la vida y el paisaje del nordeste del Brasil. Buenos Aires: Espasa Calpe, 1943, 237p. (tradução de Cayetano Romano), além de uma segunda edição de Casa-Grande y Senzala, publicada em Buenos Aires, por Emecé Editores, na Colección Grandes Ensayistas, dirigida por Eduardo Mallea, em dois volumes.

13 Recentemente, foi publicada uma antologia com textos de Freyre sobre a América Latina, já citada: Freyre (2003c). Nessa obra estão reunidos os textos escritos por Freyre durante a viagem ao Uruguai, à Argentina e ao Paraguai (1941-1942); uma entrevista de Freyre sobre a viagem, concedida ao jornal carioca A Manhã e publicada em 01.03.1942; artigos sobre temas latinoamericanos escritos entre 1942 e 1948, posteriormente à viagem; um breve texto sobre Alfonso Reyes, publicado em 1961 na revista O Cruzeiro; além do ensaio, publicado pela primeira vez em 1963, na revista Diogène, de Paris, que abre e empresta seu título ao livro: "Americanidade e latinidade da América Latina: crescente interpenetração e decrescente segregação".

14 Na coletânea encontra-se, também, um artigo de Freyre em que elogia o trabalho do tradutor de Casa-grande $\mathcal{E}$ senzala para o espanhol, Benjamín de Garay, como promotor da cultura brasileira na Argentina e na América Hispânica, além de uma resenha do livro de Ricardo Sáenz Hayes, El Brasil moderno, publicado em Buenos Aires pelo Instituto Americano de Investigaciones Sociales y Económicas, em 1942. No texto de Freyre sobre o livro de Sáenz Hayes, o autor brasileiro destacou a percepção do argentino de que o Brasil 
cialmente pelo Governo Federal brasileiro, a partir de um pedido de realização de conferências sobre política cultural, encaminhado por Lourival Fontes, então diretor do DIP, o Departamento de Imprensa e Propaganda da ditadura estado-novista de Getúlio Vargas. ${ }^{15}$

Em conferência intitulada "A propósito da política cultural do Brasil na América”, ministrada em Montevidéu, em dezembro de 1941, Freyre proclamou, como era de se esperar, a rejeição à perspectiva que desvalorizava os trópicos e suas populações mestiçadas. E sustentou a ideia de que "dentro dessa comunidade americana há uma Indo-América ainda mais caracteristicamente americana [...] do que as zonas do continente quase exclusivamente europeias ou totalmente africanas na sua composição”. Mas renegou a validade da formação de uma unidade, ou de um bloco, que dissolvesse as particularidades, a diversidade e as expressões culturais locais e regionais. Defendeu a "pluralidade de cultura sobre a base comum, ameríndia e hispânica”. Para Freyre, a América Ibérica - que ele designa no texto como os "povos americanos de formação indo-hispânica" - deveria unir forças para resistir ao avanço do "industrialismo carbonífero e petrolífero, ansioso de mercados passivamente coloniais", que tenderia a uma "rígida uniformidade cultural de continentes inteiros sob o domínio da política ou da economia do povo triunfador". E sustentou: "a essa tendência para a uniformi-

vinha se modernizando, principalmente as suas cidades mais importantes, Rio de Janeiro e São Paulo, mas não deixou de aproveitar a oportunidade para reafirmar suas próprias interpretações sobre a formação sociocultural brasileira. Saliente-se que Ricardo Sáenz Hayes foi o autor do cuidadoso prefácio às duas edições argentinas de Casa-grande $\mathcal{E}$ senzala, já mencionadas. Em seu prefácio, também incluído na coletânea, o intelectual argentino situa Casa-grande $\mathcal{E}$ senzala no pensamento brasileiro, destacando o "alcance sociológico e antropológico" da obra, particularmente no que se refere ao reconhecimento e à valorização da mestiçagem, e percebe que, na interpretação de Freyre, ressalta a "sobrevivência do velho regime no novo, uma notória reminiscência de Tocqueville”. Cf.: Freyre (2003c), p.103-5 (“O velho Garay”); p.107-13 (“Um argentino escreve sobre o Brasil”); p.139-66 ("Gilberto Freyre e a formação social brasileira”, por Ricardo Sáenz Hayes).

15 Cf. Larreta \& Giucci (2003, p.9-10). 
dade cultural, nós, da América indo-hispânica, poderemos opor alguma resistência, unidos e conscientes da necessidade de defender valores comuns", adiantando posições que iriam reaparecer em seus textos posteriores. ${ }^{16}$

No mesmo texto, Freyre sintetizou e enfatizou suas ideias da seguinte maneira:

A contemporização do português com os valores indígenas e com os dos africanos já familiarizados com os trópicos é que tornou possível o fato de levantar-se hoje no Brasil a maior civilização moderna e, socialmente, a mais democrática nos trópicos. Civilização que é um dos exemplos mais fortes que a América pode apresentar de uma cultura em que valores de várias procedências se combinam e se afirmam numa nova expressão caracteristicamente americana e socialmente democrática e num vasto esforço, a princípio empírico, hoje científico, de harmonização do europeu com a natureza tropical e semitropical e com o ameríndio e o africano, e da assimilação, pelo americano do Brasil, mesmo quando puramente nórdica sua procedência, de valores e processos desenvolvidos pelos nativos dos trópicos. (Freyre, 1941a, p.40)

Freyre entende a "democracia" vinculada à convivência "harmônica" dos membros de uma sociedade marcada pela diversidade étnica e cultural, desconsiderando, e mesmo descartando como desimportante, o significado propriamente político da democracia. A democracia liberal, para Freyre, não tinha lugar na América Ibérica e passava por uma fase de crise e descrédito.

Freyre também não deixou de, nessa conferência, pronunciada no Instituto de Cultura Uruguaio-Brasileiro, mencionar o presidente brasileiro:

16 Freyre (2003c, p.35-46) (trechos citados às páginas 41, 42 e 44). Uma versão ampliada dessa conferência foi incorporada, posteriormente, ao livro Problemas brasileiros de antropologia, publicado em 1943. 
O Brasil de hoje - com um presidente, o Sr. Getúlio Vargas, em quem a consciência sociológica dos problemas brasileiros e americanos completa às vezes a política e, principalmente, com uma elite de pensadores e pesquisadores que já venceram, no trato de problemas antropológicos, o complexo de inferioridade do mestiço e do clima tropical - bem pode tornar-se o animador de uma política de cultura interamericana que seja ao mesmo tempo um movimento unionista e pluralista, ecologista e universalista, continentalista e regionalista; uma combinação, em suma, das vantagens da unidade e da integração do homem no meio com as vantagens da diversidade e da variedade. (idem, 1941b, p. 44-5, destaque no original)

Não há dúvidas de que Freyre, em seus textos sobre a Hispano e a Latino-América, mostrou-se sumamente preocupado com a defesa das tradições e expressões populares e regionais. Em mais de um artigo, rejeitou a incorporação avassaladora e sem critérios, pelos latino-americanos, dos valores da "Europa carbonífera e burguesa", da "Europa capitalista sobre a base do liberalismo econômico" ou "do imperialismo dos Estados Unidos". Para Freyre, esse modelo econômico-cultural estaria "em crise; talvez em franca dissolução", e a América tropical seria o lugar onde uma alternativa civilizatória poderia vicejar, com "variações de expressão, criação e tradição regional" (idem, p.45). Evidentemente, não se pode esquecer que esses textos foram escritos em meio à Segunda Guerra Mundial, com tudo o que esse gigantesco conflito significou em termos de "dessacralização" da "civilização europeia".

Freyre, em artigo intitulado Interamericanismo, publicado em La Nación, em fevereiro de 1942, defendeu o que seria, para ele, a combinação de "unidade com variedade, continentalismo com regionalismo, universalismo com localismo, história com geografia”. Considerava o interamericanismo a possibilidade de aliar integração à diversidade cultural, em oposição a uma "Pan-América indistinta, pomposamente maciça”, una. O interamericanismo poderia ser uma combinação de "energias regionais e qualidades provinciais" (idem, p.47-51). 
A defesa do retorno às tradições; a valorização da diversidade e mescla de tradições culturais distintas (ocidentais e orientais); a interpenetração dos métodos da sociologia e da história; a concepção de intra-história (presente em Unamuno), ou seja, "a vida subconsciente do povo", "as correntes profundas de seu ser" - elementos analisados por Elide Rugai Bastos como centrais no pensamento de Freyre e relacionados à recepção e incorporação, em sua obra, de ideias e formulações do pensamento espanhol - estão fortemente presentes nos textos de Freyre sobre a América Latina, escritos entre os anos 1940 e 1970. Freyre manteve, desde os anos $1930-$ década em que publicou seus trabalhos mais relevantes -, esses elementos em suas análises, não tendo havido, em meu entender, alterações substanciais em suas concepções sobre a formação sociocultural do Brasil ou do mundo ibérico, em um sentido mais amplo e genérico.

Os artigos que Freyre escreveu sobre o Paraguai evidenciam as articulações, em seu pensamento entre as concepções inspiradas pelo pensamento espanhol e suas interpretações sobre a América Latina. Ao contrário do que estamos mais acostumados a ler no Brasil - visões extremamente pejorativas em relação ao país hispano-guarani - ${ }^{17}$ os artigos de Freyre sobre o Paraguai são, de maneira muito impressionante, favoráveis. É claro que Freyre, ao longo da viagem, ao tratar de maneira positiva os países visitados, também estava agindo diplomaticamente diante de seus anfitriões. Mas não é só isso. Há uma clara disposição de Freyre em defender, idilicamente, a América Ibérica e mestiça diante de um mundo de intolerância e guerra.

Freyre publicou breves artigos sobre o Paraguai em jornais do Recife e do Rio de Janeiro, em março e abril de 1942. O Paraguai, símbolo dessa América Hispano-Índia, celebrada pelo autor per-

17 Essas visões pejorativas sobre o Paraguai aparecem, entre outros textos, em relatos de viajantes brasileiros que percorreram o país hispano-guarani. Cf.: Amaral (1927). Sobre o livro de Luiz Amaral, ver Baggio (2008, p.425-45). 
nambucano, teria preservado, segundo ele, suas tradições mais profundas, os valores tropicais e a cultura popular. Freyre considerava Assunção uma "cidade aristocrática", como os "burgos sossegados do extremo norte brasileiro, mais presos ao passado e ao sangue luso-ameríndio". E contrapôs a Assunção "aristocrática" a Buenos Aires e a São Paulo, metrópoles progressistas, mas cosmopolitas e descaracterizadas. Além disso, comparou Assunção a Charleston, capital da Carolina do Sul, que, embora "quase estagnada", era, segundo o sociólogo, "a cidade de modos e gostos mais aristocráticos dos Estados Unidos. Cidade animada ainda, hoje, de um desdém soberano pelos yankees que venceram a Guerra Civil e tornaram-se donos das indústrias, do comércio e das companhias de navegação do sul patriarcal" (Freyre, 1942, p.63-5).

É difícil não ver na defesa que Freyre faz de Assunção, de Charleston ou das províncias argentinas - no papel de cidades e regiões mantenedoras da tradição frente ao progresso e ao cosmopolitismo avassalador - uma nostalgia da sociedade patriarcal nordestina. $\mathrm{O}$ elogio ao "aristocratismo essencial" de Assunção e à quase ausência de burgueses - apenas "um ou outro arredondado pela influência excessiva do bife portenho e de ideias liberais europeias e norteamericanas" (idem, p.65) - evidencia, inequivocamente, o lugar de onde fala Gilberto Freyre. Nas leituras freyrianas sobre a América Hispânica, a herança colonial e aristocrática das casas-grandes destaca-se na paisagem.

Em ensaio publicado 21 anos depois, Americanidade e latinidade da América Latina, de 1963, Freyre reafirmou a defesa das tradições, mas também das culturas ameríndias. Ao longo do texto, comparou e estabeleceu paralelismos entre expressões culturais mestiçadas em diferentes países latino-americanos: na literatura, na pintura, na arquitetura, na música, na dança, na culinária etc. A certa altura do ensaio, ao contrapor o "tempo-lazer" dos latinoamericanos ao "tempo-trabalho" dos anglo-saxões, Freyre afirmou que os latino-americanos teriam a ensinar aos americanos do norte as "artes de encher festiva, folclórica e esteticamente o tempo livre”, como um "tempo litúrgico, festivo, lúdico”. E concluiu: 
Estamos, neste particular, diante de um paradoxo que é o da América Latina tornar-se de repente, sob certos aspectos, pósmoderna e a América de língua inglesa, arcaica em suas atitudes e em seus hábitos, criados por três séculos de progresso à base de um sentimento apenas econômico de tempo: o de tempo-dinheiro. (idem, 1963, p.28)

O "pós-modernismo" da América Latina estaria também em sua capacidade de valorizar tradições tanto eruditas como populares e de combiná-las com o moderno, além de sua habilidade para mesclar elementos da arte popular com "arrojos experimentais".

Não é difícil vizualizar, nessas proposições de Freyre, elementos que já estavam em autores do final do século XIX, como o nicaraguense Rubén Darío e o uruguaio José Enrique Rodó, ou posteriores a Freyre, como o norte-americano Richard Morse. Questões antigas, atualizadas. ${ }^{18}$

Em seu livro Como e por que sou e não sou sociólogo, publicado em 1968, Freyre definiu-se como um escritor pertencente à tradição ibérica, mais espanhola do que portuguesa. Nesse texto, escrito na maturidade, Freyre (1968) cita Ganivet e Unamuno, entre tantas outras referências. Apesar das divergências conhecidas entre os intelectuais espanhóis mencionados por Freyre - envolvidos em intensos debates sobre a "regeneração" da Espanha, após as perdas das colônias na primeira metade do século XIX e, principalmente, o impacto da flagrante derrota na Guerra Hispano-Americana de 1898 -, o sociólogo brasileiro buscou em cada um deles ideias e perspectivas que pudessem alimentar sua visão sobre o universo cultural ibérico, ibero-americano e, mais particularmente, brasileiro. ${ }^{19}$

Sete anos depois de publicar Como e por que sou e não sou sociólogo, Freyre lançou o livro intitulado O brasileiro entre os outros hispanos: afinidades, contrastes e possiveis futuros nas suas inter-

18 Ver Dario (1898), Rodó (1991) e Morse (1988).

19 Sobre a "geração de 1898" na Espanha e a virada à direita da maioria dos intelectuais espanhóis identificados com essa geração, ver Capelato (2003, p.35-58). 
relações (1975), no qual reiterou sua filiação iberista. A obra reúne um conjunto de ensaios e conferências sobre hispanismo, iberismo, os trópicos e o "conceito ibérico do tempo". Como o próprio Freyre admitiu no prefácio, há evidentes repetições. Os vários ensaios do livro, reunidos sem um esforço de condensação, apresentam, de um modo geral, ideias repetidas, e, em alguns casos, frases e parágrafos idênticos, de maneira um tanto prolixa.

Nessa obra, Freyre (1975, p.32) defendeu a ideia de que "ser português é ser hispânico, sem ser, é claro, espanhol ou castelhano; e sem que a condição hispânica implique subordinação cultural à condição espanhola ou castelhana”. Como já observou Crespo (2003, p.188), o título é provocador, pois o brasileiro é apresentado como um entre outros hispânicos. Freyre dedicou-se, no livro, a esmiuçar sua defesa das tradições culturais ibéricas. Entre elas, a "noção hispânica de tempo", que dignifica o ócio criativo, o tempo do lazer, das festas, da conversa sem prazo para terminar - temática já explorada pelo autor em textos anteriores, como já salientado. Para o escritor pernambucano, a automação permitiria a liberação do homem para esse novo tempo, o "tempo-lazer", ao invés do "tempodinheiro", abrindo espaço para a superação "do modernismo, do europeísmo, do biologismo, do economismo nas Ciências do Homem e no começo de outra era, pós-moderna, mas ainda por classificar [...]". Segundo Freyre, o Brasil estaria inserido em uma "cultura transnacionalmente pan-hispânica", "herdeira direta tanto de valores espanhóis como de valores portugueses” (Freyre, 1975, p.41-5).

Freyre entendia o "pós-moderno" como superação de uma modernidade que via como esgotada. Sua concepção de "pós-modernidade" é devedora, provavelmente, de uma releitura das ideias do ensaísta ecrítico literário espanhol, radicado nos Estados Unidos, Federico de Onís, que, comojá mencionado, era professor da Columbia University no período em que Freyre estudou nessa universidade..$^{20}$

20 Federico de Onís (Salamanca, 1885 - San Juan de Puerto Rico, 1966) foi um dos principais representantes e difusores do hispanismo nos Estados Unidos, onde viveu de 1916 a 1954, ano em que se trasladou à ilha caribenha de Porto Rico, onde continuou sua carreira acadêmica na Universidad de Puerto Rico. 
Discípulo de Unamuno, Onís concebeu a expressão "pós-modernismo" com um sentido literário para referir-se a uma "reação conservadora", contrária ao experimentalismo do modernismo literário em língua espanhola de fins do século XIX e do início do século XX, no sentido de recuperar elementos negligenciados por esse movimento: lirismo despretencioso, tradição clássica, bucolismo etc. ${ }^{21}$ A ideia da "pós-modernidade" como retorno da tradição está afinada, como já evidenciado, com as concepções freyrianas.

Em $O$ brasileiro entre os outros hispanos, Freyre defendeu, também, um incremento do intercâmbio entre o Brasil e a América Hispânica, "sem sacrifício de sua saudável diversidade", tanto do ponto de vista político e econômico como cultural, intelectual, científico, tecnológico etc., "incluindo o combate à poluição de águas (algumas internacionais), de ares, de solos, defesa de reservas florestais" (idem, p.55-6). Chama a atenção o fato de que, em meados dos anos 1970, quando as preocupações ecológicas não estavam na pauta de debates no Brasil, em plena ditadura desenvolvimentista, Freyre tenha se preocupado com as questões ambientais, assim como com a crítica da modernidade e com o elogio de uma suposta "era pós-moderna".

Freyre supôs, como já mencionado, a existência de uma "cultura transnacionalmente pan-hispânica a que o Brasil pertence”. E contrapôs essa "cultura pan-hispânica" aos europeus do norte, sendo que a primeira seria portadora dos valores mais caros e adequados, segundo ele, para enfrentar os desafios que se apresentavam às sociedades da segunda metade do século XX: a recusa do tempo cronométrico e da noção de time is money; a adoção do tempo "lento, vago, impreciso", de ócio, lazer e criação; a interpenetração de culturas nos contatos de europeus com não europeus; a mestiçagem; a tendência à "conciliação dos contrários"; o "tratamento fraterno" de portugueses e espanhóis em relação a populações não europeias, colonizadas; a transculturação; ${ }^{22}$ a mistura de valores eruditos e

21 Cf. Onís (1934).

22 Apesar de referir-se à transculturação como uma característica positiva das relações culturais na América Latina e em outros territórios ibéricos, Freyre 
populares; a mescla de concepções cristãs, judaicas e islâmicas; a crítica aguda aos valores burgueses e calvinistas; a defesa dos trópicos como espaço da diversidade; a proposta de constituição de uma nova "ciência", a tropicologia, que também aparece, no livro, desdobrada em uma hispanotropicologia e uma lusotropicologia, dedicadas a estudar as sociedades ibéricas e mestiças dos trópicos.

Ao longo do livro, Freyre cita vários intelectuais espanhóis, principalmente os já mencionados, mas, apesar de pregar o incremento do intercâmbio cultural entre o Brasil e a América Hispânica, menciona poucos hispano-americanos - principalmente se comparado à abundância de autores europeus citados e, no caso de hispanos, a frequência com que aparecem referências a Ganivet, Unamuno, Ortega y Gasset e Julián Marías. Entre os hispano-americanos citados em $O$ brasileiro entre os outros hispanos estão o nicaraguense Rubén Darío; os argentinos Jorge Luis Borges e Juan José Sebreli; ${ }^{23}$ os mexicanos Carlos Pereyra, Amado Nervo e Alfonso Reyes; ${ }^{24} \mathrm{o}$ peruano José Carlos Mariátegui, ${ }^{25}$ entre outros. No entanto, con-

não menciona, em O brasileiro entre os outros hispanos, o etnólogo, antropólogo e sociólogo cubano Fernando Ortiz, elaborador do conceito de transculturação e que tantos interesses em comum tinha com Freyre. É fato, entretanto, que Ortiz foi citado em outras obras de Freyre, como Casa-grande E senzala e Como e por que sou e não sou sociólogo, ainda que, no clássico de 1933, em notas de rodapé.

23 Freyre faz uma breve menção ao ensaio Buenos Aires, vida cotidiana y alienación (1964), de Sebreli, a quem chama de "pós-marxista argentino". Cf. Freyre (1975, p.107).

24 Com Alfonso Reyes, Freyre estabeleceu laços de amizade durante os anos em que o intelectual e diplomata mexicano assumiu a embaixada de seu país no Brasil (1930-1936).

25 A rápida menção de Freyre a Mariátegui contém elogios à sua proposição de um projeto socialista adequado à realidade peruana, mas é permeada pelas interpretações freyrianas e, muito provavelmente, por um conhecimento bastante superficial das concepções do socialista peruano. Assim afirma Freyre: “esse senso ecológico ou tropicalmente político, capaz de repelir europeísmos marxistas para procurar desenvolver soluções situacionais de problemas de governo e de organizações socioeconômicas, já madrugara tanto em notável pensador peruano Mariátegui do começo deste século [...]”. Ver Freyre (1975, p.79) (citado conforme a redação original). 
forme observou Crespo (2003, p.193), não há registros de "contatos sistemáticos de Freyre com o universo acadêmico hispano-americano", assim como não se estabeleceram diálogos frequentes com seus intelectuais e não houve a "incorporação, por parte de Freyre, de referências e contribuições especificamente relacionadas a autores hispano-americanos", com a exceção, já conhecida, do conceito de transculturação, do cubano Fernando Ortiz. De fato, apesar de suas concepções iberistas e hispanistas, Freyre não estabeleceu, de um modo geral, intercâmbios frequentes com intelectuais hispanoamericanos e não incorporou às suas reflexões, a despeito de temas e preocupações comuns, de forma consistente e sistemática, contribuições de escritores e pensadores dos países vizinhos, a não ser em casos excepcionais. Entretanto, vale notar que em Freyre, a despeito do reconhecimento de suas dívidas intelectuais com pensadores europeus e norte-americanos, no caso de brasileiros e hispano-americanos esse reconhecimento não esteve, muitas vezes, tão evidenciado. De um modo geral, as referências a autores latino-americanos aparecem, na obra de Freyre, de maneira secundária, em notas de rodapé, como é o caso de Fernando Ortiz. Pode-se supor que Freyre admitisse mais facilmente reconhecer suas dívidas intelectuais com autores dos países centrais, mas que pretendia destacar-se entre os seus pares do Brasil e da América Hispânica como criador de um pensamento próprio e sem "precursores" ou "concorrentes" na América Latina. Sabemos que muitas das concepções de Freyre como, por exemplo, o elogio aos trópicos e à mestiçagem - já haviam sido desenvolvidas de diferentes maneiras por autores brasileiros e hispano-americanos que escreveram e publicaram antes de Freyre, particularmente na década de $1920 .{ }^{26}$

A análise de Maria Lúcia Pallares-Burke, nesse sentido, reforça a perspectiva de que a recepção das ideias sempre ocorre no sentido

26 Entre outras referências, é possível citar o famoso ensaio do mexicano José Vasconcelos, La raza cósmica, publicado originalmente em 1925, que, como se sabe, tece elogios explícitos à mestiçagem étnica e cultural dos trópicos, inspirado, inclusive, no caso brasileiro. Ver Vasconcelos (1948) e Crespo (2003, p.181-204). 
do "centro" rumo à "periferia". Ainda que a recepção, por parte de Freyre, de inúmeras ideias e concepções de pensadores europeus e norte-americanos seja inegável, a análise da autora - ao destacar, de maneira tão flagrante, as referências britânicas na obra de Freyre, a ponto de intitular seu livro Gilberto Freyre: um vitoriano dos trópicos - pode ofuscar, como parece que o próprio Freyre pretendeu fazer, suas dívidas intelectuais com autores brasileiros e hispano-americanos. Freyre, ao longo de sua trajetória, pretendeu realçar a importância e o ineditismo de suas ideias e de sua própria obra não só no Brasil e na América Hispânica como nos grandes centros intelectuais e universitários europeus e norte-americanos, e, para isso, buscou construir uma imagem de sua própria produção intelectual como original e divisora de águas, o que, de fato, em muitos aspectos, foi. Mas, com esse objetivo, reservou a muitos de seus pares brasileiros e hispano-americanos um lugar, de certa forma, secundário em sua obra. ${ }^{27}$ Vale registrar também que, além das referências intelectuais, muitas das ideias freyrianas, como ele próprio admitia, tiveram inspiração em sua experiência pessoal, em suas viagens e em seus trabalhos de campo. ${ }^{28}$

Sobre o iberismo, é possível constatar, também, que Freyre foi alargando determinadas concepções elaboradas em Casa-grande $\mathcal{E}$ senzala para espaços cada vez mais amplos. Certas características por ele atribuídas à colonização portuguesa do Brasil - a adaptabilidade dos portugueses aos trópicos, a "plasticidade" dos colonizadores lusos, a tendência à harmonização das diferenças, o “tratamento fraterno" em relação às populações não europeias etc. foram posteriormente vinculadas a todo o Império Português e, mais tarde, à colonização espanhola na América e na Ásia. As ge-

27 Agradeço a Alejandra Mailhe pela leitura cuidadosa e pelos comentários feitos a este texto, que me auxiliaram a pensar determinados pontos aqui desenvolvidos, particularmente as questões abordadas nos últimos parágrafos.

28 Sobre a importância, em Freyre, para a produção de sua obra, da viagem como experiência, como pesquisa etnográfica, como "reeducação do olhar", além da própria relevância dos relatos de viagem como fontes para o historiador, ver Nicolazzi (2006, p.240-65). 
neralizações e mistificações - já fartamente apontadas por muitos críticos nas análises de Freyre sobre a formação sociocultural da América Portuguesa - foram, em escritos posteriores, ampliadas. Nos livros $O$ mundo que o português criou, Aventura e rotina, Um brasileiro em terras portuguesas e $O$ luso e o trópico, Freyre reiterou ideias elaboradas desde Casa-grande $\mathcal{E}$ senzala sobre a maleabilidade portuguesa e sua tendência à mestiçagem e à transculturação, e ampliou essas concepções para a colonização portuguesa na África e na Ásia. Em uma análise crítica de Aventura e rotina, Mailhe (p.341, tradução nossa) sintetiza:

[... Freyre não abandona a atitude de um turista ávido de exotismos, sobretudo porque percebe do "outro" o que espera encontrar para confirmar a sua tese: as marcas que "provam" a unidade cultural lusotropical por cima de qualquer especificidade e diferença.

A ideia freyriana de um mundo lusotropical favorável à mestiçagem e à "harmonização dos antagonismos" foi ampliada, em $O$ brasileiro entre outros hispanos, para todas as regiões e países que anteriormente compunham os impérios Português e Espanhol na América, na África e na Ásia. Vale mencionar que o livro foi publicado em outubro de 1975, apenas um ano e meio depois do movimento que ficou conhecido como Revolução dos Cravos, que pôs fim ao regime salazarista/marcelista em Portugal e foi fundamental no processo de descolonização da África portuguesa.

Gilberto Freyre foi autor de uma vasta obra, construída, em geral, em torno dos mesmos temas e com as mesmas preocupações e questões centrais. Mas, apesar de reiteradamente insistir nas mesmas ideias, Freyre, como constata Skidmore (2003) - e muitos outros ensaístas e críticos -, fez afirmações discutíveis sem o devido cuidado com a argumentação comprobatória. Segundo Skidmore (idem, p.55-7):

Ao ignorar as regras do debate acadêmico normal, ele permitiu-se escolher entre argumentos sem precisar defender suas esco- 
lhas. [...] Além de seu uso inconsequente de evidências científicas, Freyre tem o hábito de afirmar como dados argumentos para os quais as provas citadas são fracas ou inexistentes. [...] Casa-grande foi escrito - e recebido - mais como manifesto do que como um trabalho acadêmico bem argumentado. [...] Freyre projetou uma exuberância e um otimismo que cativavam o leitor. Ele também era capaz de desafiar o leitor com generalizações chocantes [...]. Não obstante a prodigiosa pesquisa feita para a obra, Casa-grande parecia um livro de recortes, não um livro culto. A recusa de Freyre em seguir o formato acadêmico normal, na realidade, aumentou a sua acessibilidade ao leitor. Este resultado não foi por acidente. Foi o resultado direto da determinação ferrenha de Freyre de ser (e ser tratado como) um escritor, não um catedrático.

A afirmação de Skidmore de que "Casa-grande foi escrito mais como manifesto do que como um trabalho acadêmico bem argumentado" pode ser aplicada a muitos textos posteriores de Freyre, sendo que, em grande parte dos casos, ainda com mais propriedade. Sua obra está permeada por generalizações, essencialismos, culturalismos, impressionismos etc., ou seja, por afirmações, considerações e análises construídas quase que tão somente por "intuição" do autor, algo que Freyre não escondia, pelo contrário, valorizava em sua própria obra. Souza (2003, p.67), por sua vez, ao tratar da obra de Freyre, afirma que a "polissemia serve pouco à ciência e muito à ideologia".

Freyre construiu sua obra a partir de referências múltiplas, eruditas e diversificadas, como já salientado. Para ele, as ideias estavam nos autores para serem apropriadas, modificadas ou ignoradas, de acordo com as conveniências e interesses de sua própria análise. Freyre não estava preocupado com o fato de utilizar ideias originadas da leitura de autores de filiações teóricas e metodológicas as mais díspares. O que interessava a ele era se essas ideias poderiam auxiliá-lo na narrativa, na exposição e na argumentação de seu próprio pensamento. Usou e abusou das leituras que fez. Como ele mesmo afirmou, em sua obra "entrara 'leite de muitas vacas'; mas [...] o queijo era de seu fabrico: criação sua” (Freyre, 2005, p.39). 
A preocupação freyriana em relação às "ideias fora do lugar" estava relacionada à sua recusa das concepções liberais, democrático-liberais e marxistas. ${ }^{29} \mathrm{Seu}$ anti-individualismo, sua rejeição à conveniência da adoção de concepções liberais ou marxistas no Brasil - assim como na América Ibérica -, sua negação dos princípios da democracia política - soberania popular, sufrágio universal, cidadania -, fizeram com que sua obra e sua trajetória se encaminhassem decididamente para o conservadorismo e para concepções políticas de direita. Ele próprio reconhecia ser um "conservador", embora não admitisse ser chamado de "reacionário". ${ }^{30}$

Para Freyre, estavam "no lugar”, na América Latina, concepções como: tropicalismo; iberismo; hispanismo; lusotropicalismo; hispanotropicalismo; transculturação; raízes culturais, mescladas, ibéricas, africanas, islâmicas e indoamericanas; tradições; mestiçagem etc. E "fora do lugar": liberalismo; individualismo; puritanismo; calvinismo; capitalismo acelerado; modernidade industrial; marxismo, entre outras.

Souza (2003), em texto já citado, chama a atenção para uma questão fundamental no pensamento de Freyre: a percepção de que aquele Brasil de Casa-grande E senzala tinha sido "ferido de morte" com a modernização que teve início no século XIX, vinculada à implementação do Estado racional e do mercado capitalista. Esse processo de modernização tinha abalado radical e paulatinamente as estruturas e relações sociais tradicionais, tão estimadas por Freyre. E o ensaísta pernambucano percebeu claramente essas mudanças na sociedade brasileira e dedicou-se a tentar barrar ou, ao menos, retardar o processo de modernização. Como afirma Souza (idem), a implantação do Estado racional e do mercado capitalista não era artificial, para inglês ver, não estava "fora do lugar", era algo concreto. Esse processo não implicava, entretanto, apenas transformações nas esferas política e econômica, mas alterações nas percepções e valores culturais. Segundo Souza (idem, p.75):

29 Sobre o debate acerca das "ideias fora do lugar" e "ideias no lugar", ver Schwarz (2000, p.9-31) e Franco (1976, p.59-64).

30 Ver Bastos (2003, p.52). 
Aqui não se trata da inautenticidade da nossa modernidade lembrada por vários críticos, mas precisamente o fenômeno contrário. [...] A ansiedade de ser moderno, a grande vontade galvanizadora nacional desde o começo da reeuropeização até hoje, nos impede que sejamos modernos ao nosso modo e até, no limite, que nos reconheçamos enquanto tais.

Esse processo de modernização possibilitou, também, a ascensão de grupos intermediários, estimulados por perspectivas individualistas e valorativas do trabalho e do engenho pessoal. Ou seja, Freyre percebeu as mudanças fundamentais que alteravam, aos poucos, os valores dominantes na sociedade brasileira e que significavam, a médio e longo prazo, o desprestígio das oligarquias latifundistas, que passavam a ser consideradas como "classes ociosas" e usurpadoras da riqueza nacional. Sendo assim, Freyre assumiu a difícil tarefa de preservar as tradições e valores dessa sociedade patriarcal em crise.

Vale registrar, finalmente, que as referências britânicas de Freyre estavam, igualmente, eivadas pela tradição, que ele tanto cultivou em sua experiência em Oxford. Registre-se que, em 1971, a Rainha Elizabeth II conferiu a Gilberto Freyre o título de Sir, "Cavaleiro Comandante do Império Britânico". ${ }^{31}$

\section{Referências bibliográficas}

AMARAL, L. A mais linda viagem: um "raid" de vinte mil quilômetros pelo interior brasileiro. São Paulo: Melhoramentos, 1927, 113p.

ARAÚJO, R. B. de. Guerra e paz: Casa-grande E senzala e a obra de Gilberto Freyre nos anos 30. 2.ed., São Paulo: Editora 34, 2005. (1 ${ }^{\text {a }}$ edição de 1994)

31 Cf. N. da E. Dados biobibliográficos do autor. In: Freire (1975, p.17) e A vida: cronologia. In: Biblioteca Virtual Gilberto Freyre. Fundação Gilberto Freyre. Recife, PE. Disponível em: <http://prossiga.bvgf.fgf.org.br/portugues/ vida/cronologia.html>. Acesso em: jun. 2009. 
BAGGIO, K. G. Dos trópicos ao Prata: viajantes brasileiros pela Argentina nas primeiras décadas do século XX. História Revista, Goiânia, UFG, v.13, n.2, jul./dez. 2008, p.425-45.

BASTOS, E. R. Gilberto Freyre e o pensamento hispânico: entre Dom Quixote e Alonso El Bueno. Bauru: Edusc, 2003.

CAPELATO, M. H. R. A data símbolo de 1898: o impacto da independência de Cuba na Espanha e Hispanoamérica. História, São Paulo: Editora Unesp, v.22, n.2, 2003, p.35-58.

CASTRO, C. Prólogo. In: GANIVET, Á. Idearium español. Madrid: Biblioteca Nueva, 1897, p.8-9.

COSTA LIMA, L. Apresentação. In: ARAÚJO, R. B de. Guerra e paz: Casa-grande $\mathcal{E}$ senzala e a obra de Gilberto Freyre nos anos 30. In: KOSMINSKY, E; LÉPINE, C. \& PEIXOTO, F. A. (Orgs.). Gilberto Freyre em quatro tempos. Bauru: Edusc; São Paulo: Editora Unesp, 2003, p.41-64.

CRESPO, R. Gilberto Freyre e suas relações com o universo cultural hispânico. In: KOSMINSKY, E. V.; LÉPINE, C.; PEIXOTO, F. A. (Orgs.). Gilberto Freyre em quatro tempos. Bauru: Edusc; São Paulo: Editora Unesp, 2003.

DARÍO, R. El triunfo de Calibán. Buenos Aires: El Tiempo, 20 maio 1898. Disponível em: <http://www.ensayistas.org/antologia/XIXA/dario>. Acesso em: jun. 2009.

DEL PRIORE, M. Um diário, a carne e a pedra em Gilberto Freyre. In: PAIVA, E. F.; ANASTASIA, C. M. J. (Orgs.). O trabalho mestiço: maneiras de pensar e formas de viver - séculos XVI a XIX. São Paulo: Annablume: PPGH/UFMG, 2002, p.19.

FRANCO, M. S. de C. As ideias estão no lugar. In: Cadernos de Debate. n.1. São Paulo: Brasiliense, 1976, p.59-64.

FREYRE, G. O mundo que o português criou: aspectos das relações sociais e de cultura do Brasil com Portugal e as colônias portuguesas. 2.ed. Rio de Janeiro: José Olympio, 1940.

A propósito da política cultural do Brasil na América. In: Americanidade e latinidade da América Latina e outros textos afins. s. 1., s. n., 1941a. Americanidade e latinidade da América Latina: crescente interpenetração e decrescente segregação. In: Americanidade e latinidade da América Latina e outros textos afins. s. 1., s. n., 1941b, p.28 (texto publicado originalmente em Paris, na revista Diogène, em 1963).

Casa-Grande y Senzala: formación de la familia brasileña bajo el régimen de la economía patriarcal. Tradução de Benjamín de Garay e 
prefácio de Ricardo Sáens Hayes) Buenos Aires: Biblioteca de Autores Brasileños, 1942, 2 tomos.

Um brasileiro em terras portuguesas: introdução a uma possível lusotropicologia acompanhada de conferências e discursos proferidos em Portugal e em terras lusitanas e ex-lusitanas da Ásia, da África e do Atlântico. Rio de Janeiro: José Olympio, 1953.

O luso e o trópico: sugestões em torno dos métodos portugueses de integração de povos autóctones e de culturas diferentes da europeia num complexo novo de civilização, o lusotropical. Lisboa: Comissão Executiva das Comemorações do V Centenário da Morte do Infante D. Henrique, 1961.

. Como e por que sou e não sou sociólogo. Brasília: Editora UnB, 1968.

O brasileiro entre os outros hispanos: afinidades, contrastes e possíveis futuros nas suas inter-relações. Rio de Janeiro: José Olympio; Brasília: Instituto Nacional do Livro/MEC, 1975, p.32.

Tempo de aprendiz. São Paulo: Ibrasa/INL-MEC, 1979, p.305-6, apud BASTOS, Elide Rugai. Gilberto Freyre e o pensamento hispânico. s. 1., s. n., s. d., p.51.

Aventura e rotina: sugestões de uma viagem à procura das constantes portuguesas de caráter e ação. 3.ed. revista. Rio de Janeiro: Topbooks, 2001.

Casa-grande $\mathcal{E}$ senzala. 41.ed. Rio de Janeiro: Record, 2000.

Ordem, liberdade, mineiridade. In: 6 conferências em busca de um leitor. Rio de Janeiro: José Olympio, 1965, apud PALLARES-BURKE, M. L. G. Gilberto Freyre: um nordestino vitoriano. Bauru: Edusc, 2003a, p.111-2.

Nordeste. Rio de Janeiro: Record, 1989, p.166 (1ª edição de 1937), apud PALLARES-BURKE, M. L. G. Gilberto Freyre: um nordestino vitoriano. Bauru: Edusc, 2003b, p.112.

Americanidade e latinidade da América Latina e outros textos afins. Prefácio de Enrique Rodrigues Larreta \& Guillermo Giucci. In: FONSECA, E. N. (Org.). s. 1.: s. n. 2003c.

KOSMINSKY, E.; LÉPINE, C.; PEIXOTO, F. A. (Orgs.). Gilberto Freyre em quatro tempos. Bauru: Edusc; São Paulo: Editora Unesp, 2003.

LARRETA, E. R.; GIUCCI, G.. Prefácio. In: FREYRE, G. Americanidade e latinidade da América Latina e outros textos afins. s. 1.: s. n., 2003 p.9-10.

LARRETA, E. R.; GIUCCI, G. Gilberto Freyre: uma biografia cultural. Rio de Janeiro: Civilização Brasileira, 2007. 
MAILHE, A.. Ulises en el trópico. Reflexiones sobre el viaje de Gilberto Freyre por Asia y Africa, a partir de algunas tesis recientes. Katatay. Revista Crítica de Literatura Latinoamericana. La Plata, Argentina: Aurelio, Año II, n.3/4, mayo 2006, p.161-6.

Una celebración de los orígenes espurios. Mestizaje y cultura portuguesa en el luso-tropicalismo de Gilberto Freyre. In: MAILHE, A.; REITANO, E. (Comps.). Pensar Portugal: reflexiones sobre el legado histórico y cultural del mundo luso en Sudamérica. La Plata: Facultad de Humanidades y Ciencias de la Educación (FaHCE), Universidad Nacional de La Plata (UNLP), 2008, p.331-55.

MORSE, R.. O espelho de Próspero. São Paulo: Companhia das Letras, 1988. NICOLAZZI, F. Gilberto Freyre viajante: olhos seus, olhares alheios. In: GUIMARÃES, M. L. S. (Org.). Estudos sobre a escrita da história. Rio de Janeiro: 7Letras, 2006, p.240-65.

ONÍS, F. de(Ed.). Antología de la poesía española e hispanoamericana (18821932). Madrid: Centro de Estudios Históricos, 1934.

PALLARES-BURKE, M. L. G. Gilberto Freyre: um vitoriano dos trópicos. São Paulo: Editora Unesp, 2005, p.39-41.

. Gilberto Freyre: um nordestino vitoriano. In: KOSMINSKY, E. V.; LÉPINE, C.; PEIXOTO, F. A. (Orgs.). Gilberto Freyre em quatro tempos. Bauru: Edusc, 2003, p.83-114.

RIBEIRO, D. Gilberto Freyre: uma introdução a Casa-grande $\mathcal{E}$ senzala. In: FREYRE, G. Casa-grande E senzala: introdução à história da sociedade patriarcal no Brasil. 41.ed. Rio de Janeiro: Record, 2000, p.11-42 RODÓ, J. E. Ariel. Campinas: Editora da Unicamp, 1991.

SCHWARZ, R. As ideias fora do lugar. In: Ao vencedor, as batatas: forma literária e processo social nos inícios do romance brasileiro. São Paulo: Duas Cidades; Ed. 34, 2000, p.9-31. (texto originalmente publicado em 1973)

SKIDMORE, T. E. Raízes de Gilberto Freyre. In: KOSMINSKY, E.; LÉPINE, C.; PEIXOTO, F. A. (Orgs.). Gilberto Freyre em quatro tempos. São Paulo: Edusc, 2003, p.41-64..

SOUZA, J. A atualidade de Gilberto Freyre. In: KOSMINSKY, E.; LÉPINE, C.; PEIXOTO, F. A. (Orgs.). Gilberto Freyre em quatro tempos. São Paulo: Edusc, 2003.

VASCONCELOS, J. La raza cósmica. México: Espasa-Calpe, 1948. 


\section{2 \\ INTELECTUAIS, HISPANISMO E A REFORMULAÇÃO DA IDENTIDADE NACIONAL ARgENTINA}

José Luis Bendicho Beired ${ }^{1}$

O problema da identidade nacional constituiu um tópico central do debate intelectual argentino entre fins do século XIX e as primeiras décadas do novo século. Embora a federalização da cidade de Buenos Aires, em 1880, tenha significado o marco definitivo da consolidação política do Estado Nacional, o mesmo não podia ser afirmado em relação à construção da nacionalidade, entendida aqui como singularidade cultural do povo argentino. Naquele ano haviam ingressado no país em torno de cinquenta mil imigrantes, cifra que rapidamente cresceu nos anos seguintes, tornando a Argentina o país de maior proporção no mundo de população estrangeira em relação aos habitantes nacionais.

Os perigos da imigração em massa foram exaustivamente discutidos na imprensa e no mundo político, com ampla participação de intelectuais, dando origem a um elenco de respostas que se traduziram em iniciativas estatais e da sociedade civil com vistas a

1 Doutor em História e professor da UNESP - Assis, é autor de Sob o signo da nova ordem. Intelectuais autoritários no Brasil e na Argentina (1914-1945). São Paulo: Loyola, 1999, Breve história da Argentina. São Paulo: Ática, 1996; e Movimento operário argentino. Das origens ao peronismo (1890-1946). São Paulo: Brasiliense, 1984. 
afirmar não só o conceito de identidade argentina, mas também a promover a nacionalização dos novos contingentes imigratórios. Naquele ambiente de debate sobre nacionalidade, produziu-se uma surpreendente mudança de posição em relação à herança espanhola na Argentina e sobre as relações que deveriam ser estabelecidas entre ambas as nações. Parte de um processo de circulação de ideias que conectou os dois lados do Atlântico, essa redefinição repercutiu sobre as representações das identidades nacionais, mobilizando defensores e críticos da tradição hispânica. Se o anti-hispanismo havia sido hegemônico entre as elites políticas e intelectuais liberais vitoriosas contra os caudilhos federalistas, em direção ao final do século XIX delineou-se uma forte corrente de opinião pautada por uma visão positiva do legado espanhol, a qual repercutiu nas posições do Estado e da sociedade argentina. Como procuraremos discutir a seguir, essa guinada implicou na vinculação da nacionalidade argentina à civilização hispânica. Nas páginas seguintes, examinaremos primeiramente os elementos que explicam o surgimento da tendência de revalorização da herança espanhola, para em seguida examinar o papel desempenhado por certos intelectuais na defesa da Espanha e na reformulação da identidade nacional. Embora muitos personagens tenham participado desse processo, concentraremos a atenção sobre quatro dos mais relevantes: Joaquin V. González, Estanislao Zeballos, Manuel Gálvez e Ricardo Rojas.

\section{Do repúdio à confraternização com a "mãe Espanha"}

O repúdio à herança espanhola foi uma consequência lógica das tensões políticas geradas pelo movimento de independência, que tornaram o anti-hispanismo dominante na região do Rio da Prata durante a maior parte do século XIX. O anti-hispanismo foi sustentado principalmente pelos personagens vinculados ao campo ideológico liberal, os quais associavam a Espanha ao absolutismo monárquico, à falta de liberdade, à intolerância da Inquisição e ao 
parasitismo econômico. Domingo Faustino Sarmiento, Juan Bautista Alberdi e Juan Maria Gutierrez foram, entre outros, expoentes da crítica à Espanha. Em sua viagem à Espanha, em 1849, Sarmiento extraiu as piores impressões possíveis sobre a decadência e o atraso em relação ao restante da Europa. Antes, no Facundo, já formulara a proposta de substituir a imigração espanhola por outras até que Buenos Aires ficasse totalmente desespanholizada. Na mesma linha, Alberdi negava toda possibilidade de progresso aos povos americanos que não substituíssem sua população por imigrantes da Europa Centro-Ocidental, de modo que os saxões substituíssem os “espanhóis debilitados pela servidão colonial”. No âmbito cultural, o repúdio à Espanha levou o escritor Juan Maria Gutierrez a recusar a indicação como membro correspondente da Real Academia de la Lengua, afirmando ser "perigoso para um sul-americano" a aceitação do título, pois implicava a submissão de um homem livre à sua autoridade, além de considerar a Espanha de então carente de inteligência e progresso. O presidente Bartolomé Mitre foi outro que também refletiu sobre a Espanha, embora de forma ambivalente, pois, se por um lado admitia a herança cultural deixada durante o período colonial, criticava diversos aspectos da colonização espanhola, por ele considerada inferior à inglesa na América do Norte, além de condenar o absolutismo e a falta de liberdade econômica: "La madre patria no era ni podia ser para los americanos ni uma pátria ni uma madre: era una madrastra" (Mitre, 1994, p.69). Como contrapartida a essa visão negativa, o futuro da Argentina passava pelo repúdio e o abandono de tudo que fosse espanhol, ao lado da preferência pelo modelo político norte-americano, pela cultura francesa e pelas relações econômicas com a Inglaterra.

Em contraste com a corrente anti-hispanista, certos intelectuais passaram a considerar a herança espanhola como parte integrante da nacionalidade. Segundo Nicolas Shumway (1992, p.310), em contraponto à corrente anterior, formou-se outra, defensora das mesclas culturais e orgulhosa da tradição hispânica. Enumera como seus expoentes as figuras de José Hernandez, autor do famoso Martin Fierro, Olegario Andrade e Carlos Guido y Spano. Essa 
nova forma de encarar os vínculos entre a identidade argentina e a herança colonial teve como resultado, entre outros, a formação da corrente criollista, a qual teve enorme sucesso de público ao valorizar as mesclas culturais do passado rio-platense por meio de obras literárias, teatrais, musicais e pela pintura.

O desenvolvimento dessas perspectivas polêmicas fazia parte da história das relações culturais e políticas entre a Espanha e a América Latina, isto é, inscrevia-se em um âmbito mais amplo, sem o qual é impossível compreender não apenas as polêmicas em questão, mas também seus desdobramentos. Desde a década de 1830, há evidências dos esforços empreendidos por intelectuais dos dois lados do Atlântico no sentido de estreitar as relações entre as jovens nações e a antiga metrópole. Tais ações materializaram-se na formação do pan-hispanismo, movimento votado à criação de uma comunidade internacional de países hispânicos. A partir de meados do século XIX diversas publicações empenharam-se nesse sentido, a exemplo da Revista Española de Ambos Mundos (1853-1855), a revista La América, Crónica Hispano-Americana (1857-1886) e La Ilustración Española y Americana (1869-1921). A emergência do conceito de "raça espanhola" na década de 1840, portanto anteriormente ao aparecimento das ideias racistas do Conde Joseph Arthur Gobineau, ocorreu pela mão de políticos, escritores e jornalistas empenhados na reconciliação entre a Espanha e suas ex-colônias.

Os conflitos dos Estados Unidos com o México e a política do Destino Manifesto vieram reforçar a tese da particularidade das raças, como exemplificam os artigos do dominicano Francisco Muñoz del Monte, nos quais sustentava que dois grandes grupos rivalizavam entre si no continente americano: a raça latina e as raças anglo-germânicas. Por sua vez, o colombiano José María Samper, contrário à tese das raças, argumentava que o verdadeiro conflito era entre civilizações, antecipando, dessa forma, os argumentos do Ariel de Rodó: de um lado encontrava-se a hispano-americana, representando a justiça e a moralidade, e de outro, os Estados Unidos, encarnando a força bruta e a barbárie. Formou-se, pois, um ambiente que estimulou o desenvolvimento de projetos de con- 
federação política e de aliança militar entre a Espanha e os países latino-americanos entre os anos de 1850 e 1860. Concebidos por jornalistas, escritores e diplomatas da Espanha e da América, tais projetos, no entanto, foram vetados pelos governos espanhóis e não chegaram a empolgar seus congêneres americanos, de tal modo que o único campo livre para tais experimentos foi o das relações culturais e intelectuais.

No caso da Argentina, uma conjunção de fatores concorreu para a reaproximação com a Espanha. Um papel relevante foi desempenhado por espanhóis que, perseguidos na península após a queda da efêmera Primeira República (1873-1874), buscaram exílio na Argentina. Tal corrente imigratória, integrada por profissionais, jornalistas, escritores e artistas, impulsionou uma série de atividades artísticas e editoriais que ampliaram o prestígio da cultura e da coletividade espanhola na sociedade argentina. Um papel importante também coube à presença do maior contingente imigratório espanhol das Américas e à influência dessa coletividade exercida por meio de suas numerosas associações, de uma imprensa com dezenas de jornais e inclusive por meio de uma burguesia detentora de importantes empresas. Por fim, o empenho da coletividade espanhola no estreitamento de relações entre o seu país de origem e a Argentina conjugou-se a toda uma operação desenvolvida a partir da Espanha para a reaproximação com a América Latina. Uma dessas iniciativas foi a criação da Unión Ibero-Americana, no ano de 1885, por um grupo de intelectuais, políticos e empresários espanhóis. Declarada de utilidade pública pelo Estado espanhol, constituiu nos cinquenta anos seguintes um dos mais importantes instrumentos para a conquista daquele objetivo.

Em 1892, as comemorações do IV Centenário do descobrimento da América, realizadas na Espanha sob o patrocínio governamental, destacou-se como outro empreendimento do final de século concebido na mesma direção, ao qual acudiram representantes de todos os países latino-americanos. Uma das mais importantes partes da programação foi a realização de congressos que versaram sobre os temas mais variados do campo das Ciências, das Artes e da Lite- 
ratura em relação aos problemas jurídicos e militares. Buscava-se, dessa forma, impulsionar a aproximação tanto por meio do debate de temas científicos e culturais quanto mediante medidas práticas.

Entretanto, a defesa do estreitamento de laços entre a América e a Espanha não encontrou suficiente repercussão na Argentina e no restante da América Latina até que um fato político criasse as condições para tanto. $\mathrm{O}$ ano de 1898 foi decisivo. $\mathrm{O}$ ingresso dos Estados Unidos na Guerra de Independência de Cuba teve uma peculiar leitura no ambiente latino-americano, segundo a qual a Espanha, de agressora, passou ao papel de vítima e acabou por galvanizar a simpatia dos governos e da opinião pública latino-americana.

Como assinala o historiador Antonio Niño (1987, p.203), embora 1898 tenha sido um desastre traumatizante para a Espanha, acabou por render frutos ao permitir a eliminação do principal obstáculo que se antepunha à reconciliação com as antigas colônias. Os adversários de ontem tornaram-se os novos aliados e ganhou corpo a divisa do "patriotismo de raça" sustentada pelos pan-hispanistas. Em seguida à intervenção norte-americana na guerra, a coletividade espanhola de Buenos Aires promoveu uma manifestação no teatro Vitória em apoio à Espanha e contra os Estados Unidos que contou com a participação de inúmeras autoridades e personalidades argentinas. Na ocasião, Roque Saénz Peña (206, p.111-22), então ministro de Relações Exteriores, proferiu um discurso intitulado "Por España", no qual repudiava a ação norte-americana, vendo-a como um perigo para os países latino-americanos ao mesmo tempo em que solidarizava-se com a Espanha e declarava sua esperança na vitória desse país. A manifestação de Saénz Peña não era fortuita. Como membro da delegação argentina na Conferência de Washington de 1889, fez veementes críticas ao expansionismo dos Estados Unidos e defendeu a autonomia dos países hispanoamericanos em nome de uma identidade comum derivada da filiação à "mãe Espanha".

Depois da derrota em Cuba, uma série de iniciativas contribuiu para aproximar a Argentina e a Espanha, tanto no âmbito cultural quanto diplomático. Em 1900, o governo argentino ordenou que 
apenas uma parte do Hino Nacional fosse cantada nas escolas e nos atos oficiais, com vistas a suprimir uma estrofe considerada ofensiva à Espanha. ${ }^{2}$ Em 1909, a passagem do historiador espanhol Rafael Altamira pela Universidade de La Plata abriu um novo ciclo para as relações científicas e culturais entre os dois países, ensejando a criação de cátedras e o intercâmbio de professores. Por sua vez, as comemorações do Centenário da Independência, em 1910, foram as maiores do início do século e contaram com grandes preparativos que incluíram a visita da infanta Isabel em representação do rei da Espanha, Alfonso XIII. A celebração foi apresentada pelas autoridades e amplamente divulgada pela imprensa como a consagração de uma irmandade que enterrava antipatias e desentendimentos passados. Em seguida, em 1914, foi criada uma entidade que desempenhou inúmeras atividades nas décadas posteriores, a Instituição Cultural Espanhola de Buenos Aires, por iniciativa da coletividade de imigrantes, e que, entre outras iniciativas, destacou-se por manter uma cátedra de professores universitários espanhóis que possibilitou a estadia na Argentina de alguns dos mais renomados nomes do mundo científico e cultural da época. Finalmente, em 1917 o presidente Hipólito Yrigoyen decretava a criação do Dia da Raça, transformando o 12 de outubro em feriado para a comemoração do descobrimento da América e da fraternidade hispano-argentina.

A inflexão da imagem da Espanha na Argentina não teria sido possível sem o concurso de seus homens de letras, em vista de sua influência nos diversos âmbitos culturais, políticos e diplomáticos. Algumas das figuras representativas da retomada da imagem da Espanha na Argentina foram: Joaquin V. González, Estanislao Zeballos, Manuel Gálvez, Ricardo Rojas, Enrique Larreta, Arturo Capdevilla, Ricardo Levene, Ernesto Quesada, Francisco V. Silva, José León Suárez, Calixto Oyuela, além de uma série de figuras que

2 A estrofe era "a sus plantas rendido um león", sendo que tais patas eram as da Argentina e o leão representava a Espanha. 
a partir do final da década de 1920 integraram a direita nacionalista argentina, sobre as quais não vamos nos debruçar nesta relfexão.

\section{O hispanismo de quatro personagens}

Joaquin V. González foi uma figura que transitou em diversos âmbitos do Estado, da universidade e do jornalismo. Iniciando a carreira política como deputado federal, desempenhou várias funções no campo educacional e ministerial. Integrou o grupo que instalou a Faculdade de Filosofia e Letras da Universidade de Buenos Aires e fundou a Universidade de La Plata, em 1905, a qual viria a ser o principal laboratório das inovações no campo universitário. Entre outros ministérios, foi titular da pasta do Interior e foi designado membro do tribunal de Haya. Em suma, foi uma figura que sustentou posições hispanistas no âmbito da alta política argentina.

Em vista de suas fortes relações com a comunidade espanhola de Buenos Aires e de suas atividades em prol da aproximação entre a Espanha e a Argentina, González recebeu o título de presidente honorário da Associação Patriótica Espanhola em Buenos Aires. Entidade fundada em 1896, para apoiar a Espanha durante a Guerra com Cuba, tornou-se a principal agrupação da comunidade espanhola argentina, ao lado do Clube Espanhol de Buenos Aires.

As posições hispanistas de Joaquin V. González (1934) encontram-se sintetizadas no discurso que proferiu na inauguração da nova sede da associação, em 1916, quando declarou "possuir sangue espanhol e sentir como espanhol". Sob o título de "La España nueva", o discurso exaltava as origens heroicas da fundação de Buenos Aires, o sacrifício investido na colonização e o orgulho das nações americanas em relação à herança dos ancestrais espanhóis. A nova Espanha era aquela que os americanos viam ressurgir das cinzas de 1898 graças aos homens de espírito superior que conduziam a regeneração do país nos vários campos da atividade humana. Por meio de um recurso metafórico utilizado à exaustão por toda a literatura hispano-americanista, os americanos são colocados como 
os filhos que sofrem com as desventuras da mãe diante das adversidades: "Los americanos la observamos atentos y conmovidos en su afanosa labor, como si de nuestra común salud se tratase: celosos de nuestro abolengo cien veces nobiliário, esperamos ansiosos el dia de la definitiva rehabilitación de la madre veneranda" (idem, p.166). Essa atitude solidária era o resultado de uma reconciliação cuja representação carecia ser inventada e disseminada junto à sociedade por meio da metáfora do filho que ao crescer necessita questionar a autoridade dos progenitores para reconciliar-se na fase madura: "Afirmadas las nacionalidades surgidas de su seno inagotable, el amor comienza a sustituir a los antiguos resabios guerreros" (idem, p.169).

Defensor do pan-hispanismo enquanto movimento que visava conservar e fortalecer os elementos que formavam o espírito comum da raça hispânica, González considerava fundamental o papel da imigração espanhola, pois seu predomínio sobre os sangues exóticos contribuiria para a preservação da essência primitiva da raça entre os argentinos. A participação no tronco civilizatório hispânico conferia ademais um lugar de proeminência à Argentina no contexto internacional, vinculando-a às grandes civilizações do passado europeu. Assim, considerava que a ascendência racial dos argentinos constituía um tesouro segundo o qual eles não podiam ser considerados recém-chegados ao cenário da civilização e da história, uma vez que ostentavam uma linhagem genealógica iberocelta-latino-helênica. A partir de tais argumentos, é possível compreender por que no discurso realizado ante a Associação Patriótica Espanhola González sustentava a superioridade da coletividade espanhola em relação às demais residentes na Argentina e a preferência que a Espanha deveria ocupar em relação a outras nações. Não menos significativo era como suas posições reforçaram o mito da Argentina branca e europeia. Embora reconhecesse a presença do negro e do índio na formação da nação argentina, considerava que o sangue branco tinha se sobreposto a ambos os grupos, permitindo definir a Argentina como nação biologicamente branca e culturalmente europeia. Esses caracteres biológicos e culturais apenas podiam oferecer os melhores presságios sobre o futuro da Argentina. 
Estanislao Zeballos (1854-1923) foi uma influente figura, cuja trajetória contribuiu para a promoção do hispano-americanismo tanto no campo político quanto intelectual. Importante estanciero que chegou a presidente da Sociedade Rural Argentina, Zeballos conseguiu como poucos aliar uma febril atividade política ao trabalho intelectual. Deputado nacional na década de 1870, dirigiu o Ministério de Relações Exteriores por três vezes e representou a Argentina nos Estados Unidos como embaixador, além de participar das conferências pan-americanas. Ao lado disso, atuou como jornalista, fundando e dirigindo a Revista de Derecho, Historia y Letras, que em seus 76 volumes publicados entre 1898 e 1923, sintetizou os debates da alta cultura argentina. Comungava o entusiasmo de outros intelectuais e homens públicos em relação à aproximação da Espanha com a Argentina, embora com um viés mais pragmático e material.

Em um artigo a propósito das comemorações do Centenário da Independência, assinalava que a "lei do coração" permitira o encontro do Gorro Frigio com a Real Coroa, mas considerava necessário deixar de lado o antiquado reino dos afetos para dirigir-se à realidade da vida, à matéria vil, disfarçada de política, que inspira as potências, move seus regimentos, dirige seus navios e acende seus canhões. Exortava o abandono dos floreios retóricos isolados dos fatos concretos, assim como os debates estéreis sobre as raças, para afirmar que o problema central do hispano-americanismo era econômico. O seu programa, convergente com as propostas da burguesia espanhola e dos liberais hispano-americanistas, apontava para a construção de um mercado internacional no qual a Espanha desempenharia o papel de polo dinâmico como produtor de manufaturas e serviços financeiros a serem consumidos pelos países da América espanhola e portuguesa. O crescimento do mercado hispano-americano contribuiria para que a economia espanhola rivalizasse com a de outros países industriais e para o ressurgimento da Espanha como potência militar. Conclamava por fim que as câmaras de comércio espanholas se pusessem a estudar os mercados americanos, que medidas fossem tomadas para a maior difusão do 
livro espanhol e que a imigração espanhola fosse estimulada para vincular mais estreitamente Espanha e Argentina.

A questão da imigração tinha um lugar central nas preocupações de Zeballos, que muitos anos antes já havia apontado seus problemas e a necessidade de neutralizá-los. Na condição de deputado, debateu a imigração em 1887, afirmando que era uma das questões mais graves da república argentina. Ao mesmo tempo em que reconhecia sua necessidade, apontava para os riscos que os estrangeiros representavam, pois estavam levando à perda do sentimento de nacionalidade. Cobrava do Congresso medidas para sua assimilação dos imigrantes à nação mediante a neutralização de práticas que os mantinham vinculados aos seus países de origem, a exemplo dos jornais, das escolas com ensino em língua estrangeira, das festividades, dos símbolos e do registro civil dos recém-nascidos nos consulados estrangeiros (Bertoni, 2001, p.38-39). Sua posição no Congresso ajuda, portanto, a explicar a preferência pela imigração espanhola, pois dessa forma, não só o idioma praticado na Argentina seria preservado automaticamente, mas principalmente representava-se um retorno às origens ao fortalecer a linhagem hispânica da sociedade argentina quando as tradições nacionais encontravam-se ameaçadas pelo que então se nomeava como o "aluvião imigratório".

A imigração constituiu uma das questões que mobilizou outros intelectuais argentinos em direção à aproximação com a Espanha. Como é notório em Joaquin V. González, outras figuras da época, tais como os escritores Manuel Gálvez e Ricardo Rojas, também se mostraram inquietos frente à cosmopolitização da Argentina e a consequente perda das raízes hispânicas da identidade nacional. Após viajarem pela Espanha, ambos desenvolveram um conjunto de ideias expressas em livros e artigos e propostas de ação para a restauração da identidade nacional.

Em suas viagens à Espanha, realizadas em 1906 e 1910, Gálvez colheu elementos de inspiração para a redação de El solar de la raza (1913), El diário de Gabriel Quiroga (1910) e Hombres de España. Por meio de El solar de la raza, Gálvez pretendia revelar aos argentinos a alma espanhola para que eles, conscientes de suas origens, 
pudessem refletir sobre seu futuro, sobretudo em função do quadro sombrio estabelecido pelo autor sobre o presente. Para ele, a Argentina havia se transformado em uma sociedade marcada pelo materialismo em razão do afluxo de imigrantes, os quais, ignorantes dos ideais patrióticos nacionais, estariam apenas preocupados com a busca de riquezas. Tomando como exemplo a missão empreendida pelos intelectuais espanhóis regeneracionistas - Angel Ganivet, Macías Picavea, Joaquin Costa, Miguel de Unamuno, entre outros -, apresentava um programa de regeneração para a Argentina centrado no estímulo do amor à pátria. Tratava-se de uma obra de evangelização a ser realizada pelos escritores, e especialmente pelos jovens, por meio dos livros, dos diários, das cátedras, entre outros instrumentos que podiam culminar até na realização de uma guerra com o Brasil para a promoção do nacionalismo:

Tenemos que predicar maniáticamente el amor a la pátria, a nuestros paisajes, a nuestros escritores, a nuestros grandes hombres; desentrañar el espiritualismo y la originalidad de nuestro pasado, y enseñar como estas cualidades de la patria vieja y pobre pude salvar, sin menoscabarla en su grandeza material, a la actual pátria viviente. (Gálvez, 1943, p.15)

Gálvez possuía uma visão nacionalista que incluía firmemente a tradição espanhola, pois considerava-a central na definição do ser argentino.

$Y$ es que nosotros, a pesar de las aparencias, somos en el fondo españoles. Constituímos una forma especial de españoles, como ellos constituyen todavia, no obstante haber desaparecido el Império Romano, uma forma especial de latinos. Dentro de la vasta alma española, cabe el alma argentina com tanta razón como el alma castellana o el alma andaluza. Somos españoles porque hablamos el idioma español, como los españoles eran latinos por que hablaban el latin. (idem, p.17)

Sua fé na "admirável raça latina” e, em especial, na "estirpe espanhola" dos argentinos fazia-o acreditar que da geografia moral 
da Espanha deveriam ser tomados os ensinamentos e as imagens espiritualistas a serem transmitidas ao povo para afirmar o caráter americano e argentino. Menos que um ponto de chegada, essa infusão de elementos da tradição hispânica constituiria um ponto de partida que, como uma semente, germinaria e se desenvolveria de maneira original dentro das condições argentinas (idem, p.18). Como herdeira da tradição latina, a Argentina deveria agradecer à decadência da Espanha, da França e da Itália por legarem as virtudes da raça latina por intermédio de seus imigrantes, mas cabia-lhe preparar-se para o desafio de criar um belo e harmonioso tipo de civilização que não fosse puramente material. Destinada a ser mais do que o celeiro do mundo, a Argentina deveria desenvolver-se mediante o impulso de uma energia secreta que, diferentemente daquela bárbara e automática, que fervia sem cessar nos Estados Unidos, constituiria uma energia harmoniosa, elegante e inteligente a serviço de um ideal (idem, p.27).

Por sua vez, Ricardo Rojas (1882-1957) destaca-se pela forma como articulou o problema da retomada da tradição espanhola ao desenvolvimento de um programa educativo cuja função central seria dotar os estudantes argentinos de espírito nacional. Além disso, ocupou importantes postos na universidade, como professor da cátedra de História da Literatura Argentina na Universidade de Buenos Aires (1913), tornando-se a principal referência acadêmica nessa área quando venceu o concurso nacional de literatura com seu livro História de la Literatura Argentina. Em 1908 viajou à Europa a mando do governo argentino para estudar o sistema de ensino de História nas escolas do continente, e como resultado apresentou um relatório publicado sob a forma de livro, em 1909, com o título de Restauración nacionalista. Em que pese a falta de interesse do governo da época, o livro foi saudado por renomados espanhóis, tais como Miguel de Unamuno e Ramiro de Maeztu, cujos artigos na imprensa portenha contribuíram para despertar o público para sua relevância, e acabou consagrado como um referência da política educacional das décadas seguintes. 
O diagnóstico de Rojas convergia com o de outras figuras da época quanto aos efeitos negativos da imigração para a manutenção da identidade nacional:

Para cohesionarnos de nuevo, para conservar el fuerte espíriu nativo que nos condujo a la independência, no nos queda outro camino que el de la educación. Las humanidades modernas que enseñan la tierra, el dioma, la tradición y la conduta del hombre dentro de la nación, ofrecen instrumentos de esa reforma. (Rojas, 1971, p.89)

E uma frase tomada de Conflitos y armonías de las razas, de Sarmiento, sintetizava suas preocupações: "Argentinos? Hasta dónde y desde cuándo; bueno es darse cuenta de ello". As multidões de trabalhadores estrangeiros, embora laboriosas, sem possuírem uma ligação afetiva com a Argentina e nem ao menos entre si, formavam uma comunidade sem consciência do território, dos ideais de solidariedade histórica, de devoção pelos interesses coletivos e pela obra dos escritores. Sob a clara inspiração de Ernest Renan, não formavam uma coletividade que, amparada por uma memória do passado, fosse capaz de estabelecer seu futuro como nação, pois esta se fundava "en la comunidad de tradición, lengua y destino sobre um território comum” (idem, p.236). Embora a pesquisa de Rojas fosse sobre o ensino de História, o resultado de suas reflexões foi muito mais amplo, pois essa disciplina possuía uma dimensão cívica a partir da qual as outras disciplinas de humanidades seriam organizadas com o fim de promover a "formação de uma consciência argentina mais homogênea” (idem, p.145).

A revalorização da tradição espanhola subjacente ao programa desse livro recebeu maior tratamento em outras obras: Blasón de plata (1910), Eurindia (1924) e Retablo español (1938). Blasón de plata foi publicado em partes no diário La Nación como oferenda à pátria para as comemorações do Centenário da Independência. Narra em tom de epopeia a trajetória da história argentina até o século XIX, quando os argentinos, ao tomarem consciência de si mesmos, passaram a padecer de um duplo erro sobre suas origens: 
pelo que tinham de americanos, acreditaram ser necessário o antihispanismo, e pelo que tinham de espanhol, abraçaram o anti-indigenismo. Em sua opinião, tais equívocos eram o resultado de uma deformação do passado gerada pelas paixões políticas, que mostravam a falta de maturidade da consciência nacional. Como resposta, Rojas propunha a busca do equilíbio de todas as forças geradoras do passado colonial, sintetizadas na miscigenação cultural entre índios e espanhóis. Essa fusão deveria constituir o referente para que dali em diante os imigrantes, e sobretudo seus descendentes, fossem nacionalizados culturalmente por meio da escola de acordo com a tradição argentina (idem, 1986, p.103-5).

Em Retablo español, Rojas apresenta o relato das impressões de sua estadia na Espanha, em 1908. A publicação dos materiais apenas em 1938, em meio à Guerra Civil Espanhola, expressava sua angústia com os destinos de um país pelo qual nutria um profundo afeto e que considerava necessário compreender: "Estas páginas mias nacen de um viejo amor, hoy dolorido. (...) No es fácil entender a España. No la entendio Napoleón, y pagó caro su extravío. Los americanos necesitamos entenderla, porque su historia es parte de la nuestra" (idem, 1938, p.9). No livro, comenta seus encontros com expoentes da cultura espanhola e reflete sobre as cidades, os festejos, os tipos populares, a literatura, o teatro, a língua, o regionalismo, a arquitetura, buscando relações que permitissem compreender a Argentina. Em quase todas as crônicas que compõem o livro o tom é de espanto e admiração com as realizações da Espanha, assim como de profunda empatia para com as personalidades e os homens do povo que ali conhecera. Sua preocupação era tanto conhecer a Espanha profunda na qual deitava parte das raízes argentinas quanto a Espanha moderna que, ao buscar superar seus impasses, destacava-se nos vários domínios da cultura e da ciência (idem, p.355). Ao compará-la com a Inglaterra, a França e a Itália, países em que estivera antes de ingressar na Espanha, afirmava que era nesta em que de fato se sentia entre irmãos. $\mathrm{O}$ mesmo valia para Portugal, onde o espanto com a familiaridade do país levou-o a forjar o conceito de "Pani- 
béria Atlântica" para definir o espaço que delimitava Espanha, Portugal, Brasil e América espanhola. ${ }^{3}$ Apesar da profusão de elogios, alertava que a necessidade de conhecer a Espanha autêntica não era para propô-la como modelo para a América, o que seria contrário à sua tese das nações como genuínos personagens históricos.

\section{Considerações finais}

As ideias dos intelectuais mencionados nem sempre coincidiam. Gálvez, que era profundo admirador do direitista francês Maurice Barrès, possuía uma visão católico-conservadora que foi evoluindo em direção à extrema-direita nos anos seguintes. Filho de uma família tradicional da província de Santa Fé, era o mais nostálgico de uma Espanha rural que ele projetava como modelo ideal de sociedade. Estanislao Zeballos apresentava a visão de um homem que lidava com a diplomacia e que buscava encarar as relações hispanoargentinas em termos comerciais e geopolíticos. Julio V. Gonzalez e Ricardo Rojas, por sua vez, eram homens vinculados à universidade que admiravam a renovação intelectual espanhola e que com ela estabeleceram contatos acadêmicos e científicos que pudessem modernizar a educação argentina.

Em contrapartida, as posições dos quatro autores evidenciam a convergência em torno de algumas constantes. Todos pertenciam ao "patriciado criollo". Eram provenientes do interior do país, descendentes de famílias tradicionais de ascendência espanhola estabelecidas na região havia décadas ou séculos, e nesse sentido a visão idealizada da vida rural e do passado pode ser interpretada como uma reação defensiva diante da nova configuração social, urbana

3 Declara haver-se deparado com um bairro de mesmo nome da capital argentina. Ao vincular este fato à nacionalidade portuguesa do piloto do navio de Don Pedro de Mendoza, fundador de Buenos Aires, propôs a tese, bastante plausível, de que o português tivesse sugerido o nome de batismo. 
e econômica do país. Em todos encontramos a valorização dos povos latinos e, sobretudo, hispânicos, invertendo a visão difundida no final do século XIX, nos Estados Unidos e na Europa, sobre a inferioridade e decadência dos povos latinos em relação aos anglo-saxões. Eram evidentes as imagens arielistas, que de resto já circulavam nos ambientes cultos antes mesmo da publicação do livro de José Enrique Rodó: o espírito bárbaro e primitivo passou a ser identificado com os Estados Unidos, e a civilização, o progresso, com a Hispano-América. Em outros termos, contrariando o prognóstico de Sarmiento e Alberdi, os hispano-americanos podiam alcançar o futuro sendo fiéis às suas raízes e a uma essência depositada no passado (Quijada, 1997, p.603).

A projeção de uma identidade em um certo ponto da história mediante a recuperação da tradição hispânica baseava-se em uma concepção cultural de nação que, longe de expressar uma peculiaridade argentina, representava uma tendência geral nos países ocidentais. No contexto dos conflitos imperialistas e da emergência da sociedade de massas, o problema da construção da nacionalidade tornou-se um assunto candente para a afirmação dos Estados na ordem internacional e para a manutenção da ordem interna. Nacionalizar equivalia a homogeneizar os diversos caracteres linguísticos e culturais das populações situadas dentro dos limites territoriais do Estado, e justamente por isso foi tão importante o concurso dos intelectuais, na medida em que eles dominavam como ninguém os símbolos a serem veiculados pela educação e pela cultura. No que concerne à Argentina, foram inventados mitos de origem que pouca ou nenhuma relevância conferiam ao legado indígena, mas que depositaram na Espanha os principais méritos pelas glórias do passado colonial. Invariavelmente a Espanha era exaltada por ter trazido a civilização europeia à América e o episódio do descobrimento era descrito como o mais extraordinário evento histórico já sucedido, graças à determinação de Colombo, ao gênio político dos reis espanhóis e à missão salvadora da religião católica. Graças à colonização espanhola, a Argentina era uma nação cujas tradições podiam orgulhosamente ser estendidas até a época grega e romana. 
Somente Rojas se distinguia por sua preocupação em propor uma identidade mestiça em que a figura do indígena possuía um lugar digno junto ao espanhol. Essa identidade foi consagrada no livro Euríndia, nome de um mito criado pela Europa e pelas Índias, mas que já não pertencia nem a uma nem a outra, pois era o produto de ambas as civilizações.

A busca da integração social das massas estrangeiras, vistas como subversivas e hostis à nacionalização, constitui um dos fatores que explicam a preocupação com a reformulação da identidade nacional, segundo parâmetros que visavam fortalecer o sentido de ordem pública. Ao lado disso, a ênfase na herança hispânica assegurava a manutenção da posição dos setores dirigentes identificados com a tradição das famílias de linhagem mais antiga. Dessa forma, enquanto a defesa da identidade hispânica facilitou a integração dos imigrantes espanhóis à sociedade argentina, cabia aos demais imigrantes adaptar-se ao novo padrão emergente de status social que conferia maior valor à comunidade espanhola. No entanto, a valorização da tradição hispânica e a aproximação com a Espanha integravam um processo complexo que envolvia diversas dimensões. O posicionamento internacional da Argentina - bem como dos demais países hispano-americanos - em relação aos Estados Unidos teve um relevante papel no sentido de produzir uma reação política e cultural que se materializou na aproximação com a Espanha e na valorização das raízes hispânicas e latinas. Nesse sentido, contemporâneos como Ernesto Quesada vislumbraram a possibilidade de a Argentina angariar o reconhecimento dos países hispano-americanos como liderança nos embates contra os Estados Unidos (Terán, 2000, p.257). Mas, apesar disso, nem tudo o que era espanhol era bem-vindo na Argentina e nem todos os espanhóis rendiam culto às imagens idealizadas da Espanha. Por exemplo, os movimentos de trabalhadores socialistas e anarquistas, cujas fileiras contavam com uma enorme massa de espanhóis, tanto repudiavam tais idealizações como eram sistematicamente reprimidos pelas autoridades, chegando a ser expulsos do país. Ou seja, a defe- 
sa da fraternidade hispânica pelos intelectuais argentinos implicava um conceito bastante conservador da ordem social.

Em termos da identidade nacional, entendemos que a defesa da herança hispânica fortaleceu o criollismo, movimento cultural que se iniciara anteriormente e que se desenvolveu nas primeiras décadas do século XX. ${ }^{4} \mathrm{O}$ termo criollo encerrava múltiplos sentidos. Com um sentido positivo, designava as formas tradicionais da vida argentina vinculada à cultura rural dos pampas e aos seus habitantes, os gaúchos. Essa era a fórmula sintetizada no poema Martin Fierro, de José Hernandez, segundo a qual os criollos eram os descendentes de espanhóis e índios, em oposição à imigração recente. Outra acepção mais restrita de criollo fazia referência aos setores dirigentes de origem colonial e ascendência espanhola. Ainda que nem todas as famílias tradicionais fossem de linhagem puramente espanhola, o importante é que o termo remetia àquelas de elevada posição social. Nesse sentido, as posições hispanizantes aqui examinadas, longe de contraditarem o criollismo, contribuíram para seu revigoramento. A defesa do legado hispânico permitia retomar positivamente a tradição colonial vilipendiada pelos liberais, ao passo que a presença do imigrante espanhol na população servia para preservar a personalidade ibérica da nacionalidade diante do aluvião imigratório não hispânico.

Nem a visão da Espanha nem a identidade hispanizante proposta pelos autores aqui analisados foram unânimes, tendo encontrado diversos opositores na Argentina. Apesar disso, suas representações ganharam um notável terreno, pautando diversos âmbitos da vida política e cultural do país, mesmo à custa da exclusão de diversos segmentos sociais, dos recém-chegados até seus antigos habitantes. ${ }^{5}$

4 Nos amparamos na análise do criollismo desenvolvida por Arnd Shneider em Inmigrantes europeus y de otros origenes. In QUIJADA, M. et al. Homogeneidad y nación con un estudio de caso: Argentina, siglos XIX y XX. Madrid: CSIC, 2000, p.141-78.

5 A exemplo de Gálvez, os integrantes da direita nacionalista argentina possuíam uma concepção hispanista que excluía os indígenas da concepção de nação. 


\section{Referências bibliográficas}

BERNABEU ALBERT, S. 1892: el IV Centenário del descubrimeinto de América. Madrid: CSIC, 1987.

BERTONI, L. A. Patriotas, cosmopolitas y nacionalistas. La construcción de la nacionalidad argentina a fines Del siglo XIX. Buenos Aires: F.C.E., 2001, p.38-9.

BIAGINI, H. Intelectuales y políticos españoles a comienzos de la inmigración masiva. Buenos Aires: Centro Editor de América Latina, 1995.

GÁLVEZ, M. El solar de la raza. 7.ed. Buenos Aires: Poblet, 1943.

GONZÁLEZ, J. V. España y la Republica Argentina. In: Politica Internacional. Buenos Aires: L.J. Rosso, 1934, p.157-9.

GONZÁLEZ, J. V. La España nueva. In: Politica Internacional. Buenos Aires: L.J. Rosso, 1934.

MITRE, B. História de San Martin. Buenos Aires: Jackson, 1941, p.54-6. Apud MACARRO, J. M. La imagen de España en la Argentina. In: SÁNCHEZ MANTERO, R. et al. La imagen de España en América (1898-1931). Sevilla: C.S.I.C., 1994, p.69.

NIÑO, A. L'Expansion culturelle espagnole em Amerique Hispanique (1898-1936). Relations Internationales. Paris, C.N.R.S., n.50, 1987, p.203.

QUIJADA, M. Latinos y anglosajones. El 98 em el fin de siglo sudamericano. Hispania. Madrid: CSIC, LVII/2, n.196, 1997, p.603.

QUIJADA, M. et al. Homogeneidad y nación con un estudio de caso: Argentina, siglos XIX y XX. Madrid: CSIC, 2000.

QUIJADA, M. Latinos y anglosajones. El $98 \mathrm{em}$ el fin de siglo sudamericano. Hispania. Madrid: CSIC, LVII/2, n.196, 1997.

RAMA, C. Historia de las relaciones culturales entre España y la América Latina. México: F.C.E., 1982.

ROJAS, R. La restauración nacionalista. 3.ed. Buenos Aires: Peña Lillo, 1971, p.89.

ROJAS, R. Blasón de plata. Buenos Aires: Hyspamérica, 1986, p.103-5.

SÁENZ PEÑA, R. Por España. In: Americanismo y democracia. Buenos Aires: Grupo Editor Universitário, 2006.

SAMPER, J. M, América y España. La America-II, 1858, apud VAN AKEN, M. op. cit., p.77.

SÁNCHEZ MANTERO, R. et al. La imagen de España en América (18981931). Sevilla: C.S.I.C., 1994.

SHUMWAY, N. La invención de la Argentina. Buenos Aires: Emecé, 1992. 
TERÁN, O. Vida intelectual en el Buenos Aires fin-de-siglo (1880-1910). Derivas de la "cultura cientifica". Buenos Aires: F.C.E., 2000, p. 257. VAN AKEN, M. Pan-hispanism. Its origin and development to 1866. Berkeley: University of California Press, 1959.

ZEBALlOS, E.. Hispania. Revista de Derecho, Historia y Letras. Año II, Tomo VI, 1900. 

PARTe II

\section{CULTURA VISUAL E PRODUÇÃO DE IMAGINÁRIOS}





\section{3 \\ IMAGINÁRIOS POLÍTICOS \\ NO BRASIL E NO MÉxICO}

Carlos Alberto Sampaio Barbosa ${ }^{1}$

O objetivo deste texto é refletir com relação à circulação de ideias culturais e políticas entre o México e o Brasil na primeira metade do século XX. Busco examinar, em especial, como se constituíram repertórios visuais comuns entre os dois países, tanto na produção de imagens carregadas com uma retórica do engajamento político como de algumas imagens que, em um primeiro olhar, poderiam passar por descompromissadas, mas que contribuíram para a construção do imaginário político latino-americano. Embora minha intenção não seja a de uma análise exaustiva, procuro averiguar diferentes suportes imagéticos, como as fotografias estampadas na imprensa diária, assim como nas revistas ilustradas, em cartazes, em gravuras e demais expressões artísticas que subsidiaram essa circulação de ideias estéticas e políticas entre ambos os países. Parto da hipótese de que, embora as dificuldades de contatos existentes, tais como a língua, a distância e a falta de maiores trocas entre seus intelectuais, ocorreram intercâmbios de propostas políticas e culturais principalmente entre redes de sociabilidade intelectuais marcadamente no âmbito da esquerda entre esses dois países.

1 Doutor em História e professor da Unesp - Assis é autor de A fotografia a serviço de Clio. Uma interpretação da história visual da Revolução Mexicana (1900-1940). São Paulo: Editora Unesp, 2006. 
Em primeiro lugar cabe uma rápida discussão sobre as balizas temporais. A pesquisa detém-se de maneira flexível no período entreguerras (1914-1945). Esse momento foi marcado por importantes acontecimentos tanto na esfera política como na cultural. No âmbito mundial, essa fase é delimitada pela Primeira Grande Guerra, conflito que mostrou os limites do projeto moderno da razão positiva e os sonhos de um progresso indefinido das sociedades ocidentais. Antes do final da guerra, e como um de seus desdobramentos, ocorreu a Revolução Russa de outubro de 1917. No espaço das Américas assistimos à eclosão da primeira revolução de cunho social do século, a Revolução Mexicana, entre 1910 e 1920, que representou um marco para todo o continente, gerando um intenso debate nos meios políticos latino-americanos. Não podemos esquecer-nos da rebelião dos estudantes a partir de Córdoba, na Argentina, em 1918, que se espalhou por todo o continente subsequentemente. Vimos também o surgimento dos partidos comunistas em vários países latino-americanos, além de um avanço geral das organizações dos trabalhadores, seguidas por uma onda de repressão.

No âmbito cultural, esse período também foi marcado pelas vanguardas artísticas. Embora seja difícil estabelecer marcos precisos de seu início, já em 1914 surge o primeiro manifesto modernista, Non Servian, de Vicente Huidobro. Entretanto, será na década de 1920, com a Semana de Arte Moderna de São Paulo, no Brasil, o início do trabalho dos muralistas no México e a publicação de Trilce, de César Vallejo, no Peru, que pode ser estabelecida como o grande momento de eclosão das vanguardas. Ademais, temos a fundação de diversas revistas culturais, tais como Amauta, no Peru, e Avance, em Cuba. Na Argentina, além da Martin Fierro tivemos o periódico de esquerda Nueva Revista, que contou com a participação de escritores e artistas em seu corpo de colaboradores e reproduziu imagens de David Alfaro Siqueiros, G. Grosz e Pablo Picasso, só para citar alguns. ${ }^{2}$

2 Além dos citados acima, poderíamos lembrar de uma vasta gama de escritores e artistas que publicaram nesse periódico, tais como: A. Ponce, C. Córdova, Iturburu, Á. Yunque, M. Gorki, John dos Passos, L. Aragon, A. Malraux, 
As revistas culturais, a propósito, foram os grandes veículos das vanguardas e ocuparam um espaço importante na difusão de repertórios visuais. Elas foram o suporte de novas experiências imagéticas, sempre com forte conteúdo político, e tiveram um papel decisivo para a fotografia e as imagens de uma forma geral. No caso da fotografia, cabe lembrar que é nesse período que surge o fotojornalismo moderno com o advento das grandes revistas ilustradas, como a $V u$ francesa e a Life norte-americana. Veremos também o surgimento de revistas populares e engajadas politicamente, tais como a Arbeiter Illustrierte Zeitung - AIZ, na Alemanha, em 1921. Esse magazine de sensibilidade comunista estampava em suas páginas fotomontagens antifascistas, como, por exemplo, os trabalhos do alemão John Heartfield, enquanto que na França teremos o surgimento da revista Regards, em 1932 (Heartfield, 1976).

Como marcos finais dessa fase podemos citar a eclosão da Guerra Civil Espanhola, que foi o campo de provas da Segunda Guerra Mundial. Esses dois acontecimentos marcaram a vida política e cultural não só mundial como latino-americana. Nos anos 1930, com o conflito espanhol como pano de fundo, veremos o surgimento da Associação de Escritores e Artistas Revolucionários, a qual, além de contar com a presença de vários escritores, teve a participação decisiva de fotógrafos como Robert Capa e Gerda Taro, que propunham uma visão militante consubstanciada na necessidade de transmitir a emoção por meio da proximidade do testemunho fotográfico.

Mas a fotografia não estava desvinculada do mundo cultural mais amplo. Muito pelo contrário. Durante o período entreguerras a imagem fotográfica tornou-se um meio privilegiado de expressão artística. Tanto que os movimentos de vanguarda, como o futurismo, o dadaísmo, o construtivismo e o surrealismo utilizaram-na como meio de expressão para romper com a representação pictórica

I. Ehrenbourg, R. Alberti, M. T. León, Antonio Machado, R. González Tuñon, H. Barbusse. A revista notabilizou-se pela impressão de imagens de M. Carmen, J. C. Castagnino e L. E. Spilimbergo. Devo essa informação ao texto de Wechsler (2006). 
do "antigo regime". Para esses artistas a fotografia era vista como uma linguagem nova, rápida, precisa, mecânica e reprodutível, em sintonia com seus objetivos. Eliminava-se assim a distância que existia entre fotografia e arte.

Durante o período entreguerras, não só a fotografia estava presente no cerne dos variados movimentos de vanguardas. Nesse sentido não podemos esquecer-nos do cinema. O cinema, assim como a fotografia são dois representantes da reprodução mecânica ou da "reprodutibilidade técnica da obra de arte", como afirmou Walter Benjamin em texto que começou a escrever em 1936 e só foi publicado pela primeira vez em 1955 (Benjamin, 1985, p.16596). As duas linguagens serão amplamente utilizadas pelos artistas interessados em uma nova sensibilidade, e nessa época surgiu o movimento conhecido como Nova Objetividade. ${ }^{3}$ Alguns casos dignos de nota são as experiências na União Soviética em torno da revista Lef (1923-1925) e depois com a Noviy Lef (1927-1929), em que participaram Rodchenko, El Lissitzky, Dziga Vertov e Maiakovsky. Estes buscavam uma nova visão coletiva ao serviço de um ideal revolucionário.

Do outro lado do Atlântico está toda uma geração de norteamericanos, que participam do projeto da Farm Security Administration (FSA) desde 1935 e posteriormente, com a criação da New York Photo League, buscam uma nova expressão fotográfica como documento social e que possibilite uma atuação social e política por meio de sua expressão artística.

O esgotamento das vanguardas deu-se ao longo da década de 1930 com o fechamento da maioria das revistas e prolongou-se durante os anos 1940 com o advento da Segunda Guerra Mundial. No tocante à situação política e social, tivemos a surgimento do fascismo e do nazismo na Europa, e na América Latina houve os

3 Talvez o principal exemplo de artista e evento que podem ser citados é a exposição Film und Foto - Fifo, em Stuttgart, em 1929, organizada por Lászlo Moholy-Nagy. Este havia escrito Malerei, Fotografie, Film em 1925. Veja mais informações em Bajac (2005, p.67). 
vários golpes militares, como no Brasil, na Argentina e no Peru, subsequentemente com a ascensão de movimentos autoritários. É o período do surgimento de uma política de massas, e podemos dizer que os artistas dentro do espírito dessa época também se radicalizaram em termos políticos entre direita (fascismo, que se apropriou do futurismo) e esquerda (comunismo, socialismo, anarquismo). No âmbito da União Soviética e dos artistas ligados aos partidos comunistas vai predominar o realismo socialista, além do que outros vão assumir tendências nacionalistas. José Carlos Mariátegui, um dos principais intelectuais latino-americanos do século XX, ao falar do esgotamento das vanguardas, diz: "os termos que falam do novo envelheceram" (Schwartz, 1995).

\section{Cultura visual na América Latina: Brasil e México em perspectiva comparada}

Não cabe aqui, nem é meu intento, realizar um panorama desse período. A proposta desta pesquisa é tratar de uma história política das imagens, ou melhor, uma história política apoiada nas imagens. A intenção é dar uma contribuição à história social e política recorrendo a uma história cultural ou a uma história visual. Outra intenção é investigar como um regime de visualidade se estabelece nas sociedades latino-americanas no período entreguerras partindo da dimensão visual como um vetor ou uma plataforma para se compreender os processos históricos de Brasil e México nesse período.

A fotografia e as imagens, assim como o rádio, a eletricidade e o cinema, estavam inseridos na transformação do espaço urbano e na transformação de uma sensibilidade visual da sociedade ocidental. Foram nas décadas de 1920 e 1930 - o período entreguerras - os anos do nascimento e desenvolvimento de uma cultura visual que vai predominar ao longo do século XX. Consubstanciada por meio das imagens fotográficas, dos anúncios publicitários, de livros, de cartazes, do cinema e das revistas culturais é que se estabeleceu uma nova cultura visual gestora de um novo imaginário político. 
Cabe aqui falar, mesmo que brevemente, do conceito de "cultura visual". Nicholas Mirzoeff, um dos principais estudiosos do tema, destaca a distância entre a riqueza visual da sociedade moderna em contraste com a pouca capacidade e/ou habilidade para analisar essa visualidade. Ele defende a necessidade de desenvolver-se um campo de estudos em que se investiguem os diferentes meios visuais e de comunicação não de forma independente, mas de forma integrada. Embora não partilhe completamente de suas propostas, a ideia de uma necessidade de estudar-se a cultura visual de forma mais integrada e ampla, independente dos seus suportes, parece-me extremamente instigante. ${ }^{4}$

Se quisermos perscrutar os intercâmbios culturais e políticos entre México e Brasil nesse período, o ponto inicial deve ser a participação mexicana na Exposição Internacional do Centenário da Independência, realizada na cidade do Rio de Janeiro em 1922. Independentemente da crise em torno da eleição presidencial e o levante militar em plena capital federal, Artur Bernardes tomou posse em novembro daquele ano, em substituição de Epitácio Pessoa. Esse foi o ano da Semana de Arte Moderna, em São Paulo, um marco na vida cultural brasileira, enquanto que no México o grupo dos estridentisdas e, em seguida, dos contemporâneos também se lançavam em uma discussão sobre como definir a cultura e a literatura nacional.

As exposições internacionais são, por excelência, polos de elementos visuais. Para essa exposição, o presidente Álvaro Obregón enviou uma delegação especial comandada pelo secretário da Educação José Vasconcelos e pelo general Manuel Pérez Treviño. A delegação, além de diplomatas de carreira, contava com pintores, poetas e escritores como Carlos Pellicer, Julio Torri e Pedro Henríquez Ureña. Foi construído um pavilhão em estilo colonial barroco desenhado pelos jovens arquitetos Carlos Obregón Santacilia e Carlos Tarditti (Anda Alanis, 2008). Os pintores, como Roberto Montenegro e Gabriel Fernández Ledesma, desenharam pinturas

4 Mirzoeff(2003, p.19). Nesse sentido, identifico-me muito mais com a proposta de uma história visual, do professor Meneses (2003, p.11-36) . 
murais para decorar as paredes interiores do edifício. $O$ pavilhão mexicano contava ainda com uma replica reduzida de Teotihuacán, móveis e um livro com inúmeras imagens, entre elas pinturas de Velasco e fotografias, realizadas pelo famoso fotógrafo Guillermo Kahlo, ${ }^{5}$ das estradas de ferro e de obras arquitetônicas. Outro elemento visual foi a exibição de uma película realizada durante a estada de Vasconcelos no Brasil e uma exposição de arte popular. Foi ademais inaugurada na confluência da Avenida Beira Mar com Oswaldo Cruz e Rui Barbosa uma escultura de Cuauhtémoc, o herói da resistência indígena asteca. Cabe mencionar que Vasconcelos viajou pelo país e realizou diversas conferências. Dessa sua estada em terras brasileiras resultou posteriormente seu livro Lar raza cósmica. No fundo, o livro são as memórias de suas viagens pelo Brasil, pela Argentina, pelo Uruguai e pelo Chile (Tenório Trillo, 1995, p.1-32).

Como já afirmei antes, as revistas e periódicos em geral são o lócus principal para a divulgação da dimensão visual. No caso mexicano, é digno de nota o jornal El Machete, do Partido Comunista Mexicano dos anos 1920, em que teremos a publicação de fotografias de Tina Modotti e gravuras de David Alfaro Siqueiros, além de Luis Arenal. Este último foi, por muitos anos, diretor do periódico.

Chama a atenção a experiência alternativa da revista Frente a Frente (1934-1938), publicada pela Liga de Artistas y Escritores Revolucionários, que teve em sua direção novamente Alfaro Siqueiros e na qual Dolores Álvarez Bravo conseguiu publicar uma fotomontagem na capa. Em um número posterior dessa revista foram publicadas fotomontagens de John Heartfield.

Por seu turno, no Brasil surge, em 1933, o jornal O Homem Livre, tendo a participação de Oswald de Andrade, Mário Pedrosa, Geraldo Ferraz e Patrícia Galvão, a Pagu. Era um semanário de política e cultura vinculado à Frente antifascista, reunindo várias correntes, principalmente trostskistas, anarquistas e socialistas. Livio

5 Guillermo Kahlo, de origem alemã e pai de Frida Kahlo, fixou-se no México e rapidamente tornou-se fotógrafo oficial das obras arquitetônicas do porfiriato. 
Abramo publicará várias de suas gravuras nesse periódico, em que retratou o cotidiano do operariado paulista e de crítica à Guerra Civil Espanhola, sempre em uma linha expressionista. Livio Abramo foi um dos mais marcantes artistas engajados do período. Militante comunista e ilustrador do jornal do PCB, foi expulso ao se recusar a fazer uma caricatura de Trotsky. Trabalhou no jornal Luta de Classes, da oposição de esquerda, no Petracchone, também socialista, e posteriormente no jornal $O$ Homem Livre.
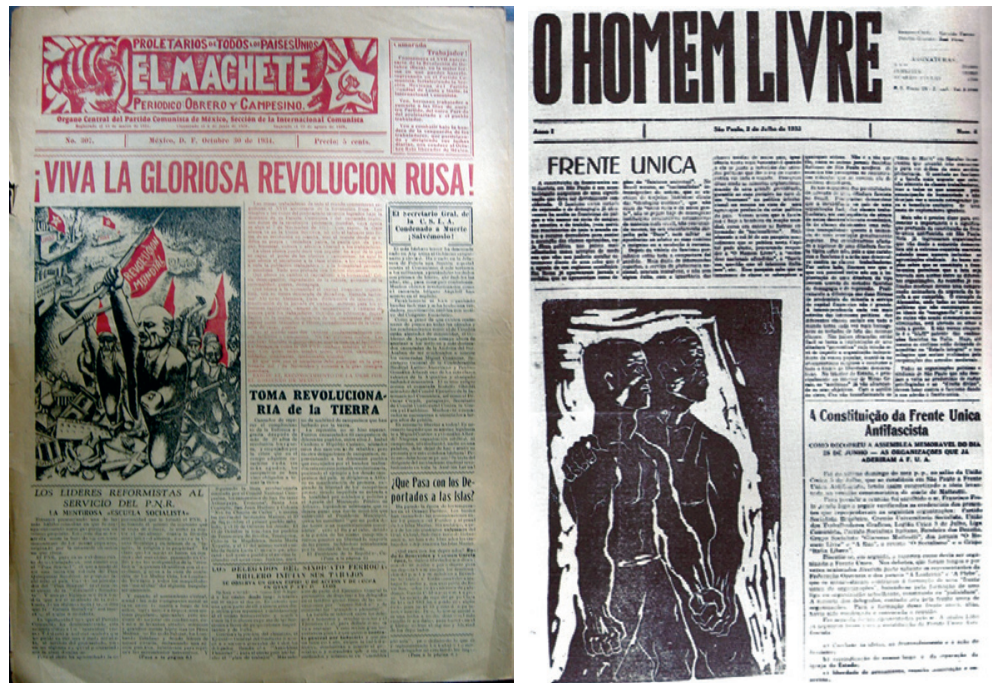

Capas dos jornais El Machete (México) e O Homem Livre (Brasil).

Algumas outras experiências merecem ser destacadas, como a revista Rotofoto, dirigida por José Pagés Llergo e Regino Hernández Llergo ${ }^{6}$, que utilizaram a fotografia como elemento principal em seu projeto gráfico. Essa revista contou em seus quadros com

6 Ambos foram editores da revista Hoy, criada em 1937, inspirada na revista norte-americana Life, em que prevaleciam os elementos visuais em seu projeto gráfico. Podemos afirmar que essa revista é similar às nossas Cruzeiro e Manchete. Para o caso mexicano, ver Monroy Nasr (2004, p.182). 
fotógrafos como Antonio Carrilo Jr., Ismael Casasola, Agustín Casasola, Enrique Díaz e outros, que publicaram imagens com enorme sentido de ironia, grandes doses de humor e sacarmos que atingiam principalmente os políticos. As fotografias com grande carga estética chegavam aos limites da ridicularização dos personagens retratados. Acusados de ataques a personalidades políticas da época, os diretores foram perseguidos e forçados a não mais publicar a revista. Embora não possamos afirmar que sejam engajadas, estamparam em suas imagens cenas de forte conteúdo político e ajudaram a construir uma cultura visual política. ${ }^{7}$

Cabe destacar a chegada ao México, no final da década de 1930, de cinco fotógrafos espanhóis conhecidos por Hermanos Mayo, nome em alusão ao Primeiro de Maio e à sua atuação política engajada, que buscavam exílio após a derrota da República na Guerra Civil Espanhola (Monroy Nasr, p.183-4).Nesse mesmo período surge o periódico El Combate, que também publica fotografias e gravuras com forte teor político.

Em terras brasileiras podemos citar como termo comparativo a revista S. Paulo, que, publicada durante o ano de 1936, alcançou apenas dez números e era comandada por Cassiano Ricardo, Menotti Del Picchia e Leven Vampré. As fotografias ficaram a cargo de Theodor Preising e Benedito Junqueira Duarte. Com um projeto gráfico ousado, em que a imagem ocupava um lugar privilegiado, expressava uma propaganda político ideológica de valorização do "espírito bandeirante" e exaltava o desenvolvimento da cidade de São Paulo. O magazine estava vinculado ao grupo político do governador Armando de Salles Oliveira, que pretendia lançar-se candidato à presidência da República, e apesar de seu projeto gráfico moderno, sua mensagem deve ser interpretada com cuidado. A publicação, assim como sua congênere mexicana Rotofoto, investiu fortemente nos recursos visuais e na fotografia. Sua programação visual moderna era marcada pela construção arrojada de suas páginas e pelo projeto gráfico vanguardista na utilização de fotomontagens.

7 Em relação à revista Rotofoto, veja texto de Barbosa Sánchez (2007, p.177-98). 

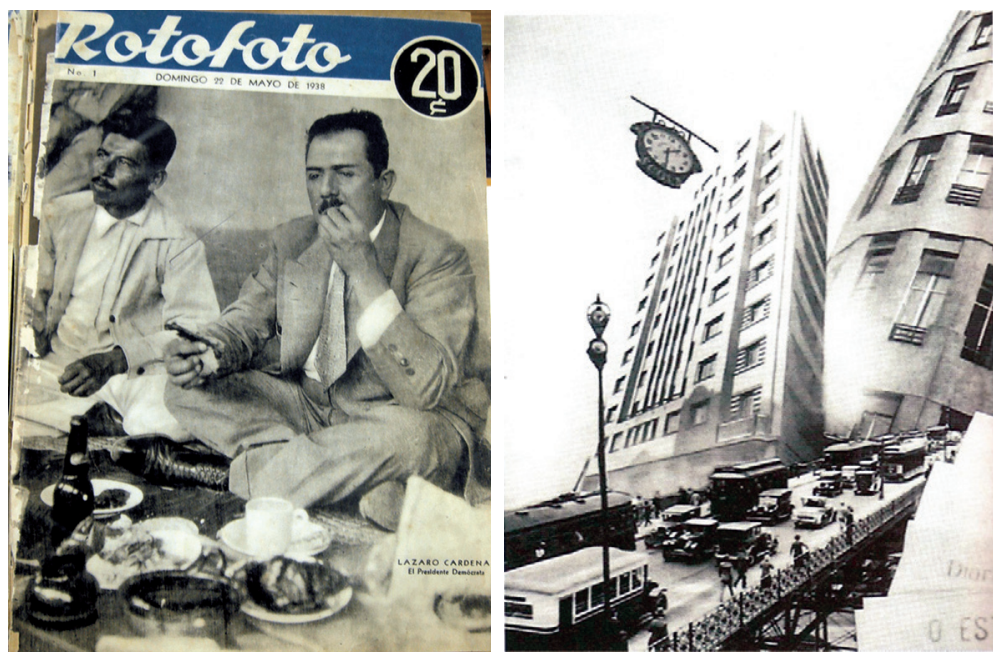

Capa da revista Rotofoto (México), 1938, e fotomontagem de Priesing e Vamp na revista S. Paulo (Brasil), 1936.

No México merece destaque a pintura mural. Já existe uma ampla bibliografia sobre o tema. Vou aqui me deter mais a trabalhos mais recentes que vêm procurando estabelecer um novo diálogo com essa produção.

A pintura mural possui uma história oficial que foi denominada como "história do bronze". Segundo Gonzalez Mello (2004, p.276), a pintura mural da Revolução foi um dos intentos mais acabados, por elaborar uma história visual sem dissidência, sem correntes e contracorrentes. Procurou construir uma só história do México pós-revolucionário, harmoniosa e em que as contradições foram omitidas. Esse mesmo autor afirma também que ao longo do século XX a construção da legitimidade se deu como uma disputa ideológica contra o catolicismo e que, nesse sentido, os murais patrocinados pelo Estado não foram por acaso pintados em igrejas, capelas e conventos expropriados pelo governo. Ocuparam esses espaços no intento de neutralizar sua força simbólica. Era uma forma de o Estado cooptar uma ala mais radical de esquerda de artistas e intelectuais e neutralizar seu discurso. O muralismo estabeleceu, 
assim, uma retórica visual buscando convencer a sociedade mexicana da legitimidade das classes sociais vencedoras do processo revolucionário.

Segundo o autor, serão temas constantes no muralismo imagens como as do presbítero e a mesa (símbolo da autoridade), a pátria e a professora e, é claro, o índio. Este último foi um dos principais atores simbólicos da revolução segundo a ótica dos muralistas. Ele foi representado como explorado e reivindicador, foi também o herói anônimo e triunfador. Representou a luta dos pobres contra os ricos, dos despossuídos contra os possuidores e de vítimas contra os verdugos. Mas os indígenas foram construídos sobre um imaginário livre de contradições no qual se elaborou o México moderno mestiço, índio e camponês. Nada mais fantasioso, tendo em vista o México pós-revolucionário e suas elites que não eram nem um pouco indigenistas, muito pelo contrário, eram racistas (idem, 2004, p.285).

Os murais também foram individualistas na representação da história mexicana na medida em que foram eleitas esfinges convencionais dos heróis históricos que lutaram pela independência, contra os conservadores e a Igreja. Foram eleitas figuras emblemáticas, tais como Miguel Hidalgo, José Maria Morelos, Benito Juarez, Francisco "Pancho" Villa e Emiliano Zapata. A grande quantidade de personagens levou, em muitos casos, à construção de galerias abarrotadas de heróis. Cabe lembrar que as imagens fotográficas produzidas e publicadas pela família Casasola ao longo desse período estabeleceram o mesmo dispositivo ao elaborar figuras emblemáticas da fundação do México Moderno (Barbosa, 2006).

Para nossa hipótese de intercâmbios dos imaginários culturais por meio das múltiplas redes dos movimentos modernos e do intenso processo de internacionalização do movimento antifascista, convém nos determos um pouco mais na figura de David Alfaro Siqueiros, um dos mais conhecidos artistas do muralismo. Em seu caso, acredito, temos dois momentos de contato mais intenso. Um primeiro que denomino Fase das Palestras, durante a década de 1930, e uma segunda fase, a das Bienais, entre 1950 e 1960. 
Talvez um dos primeiros contatos de Siqueiros com o Brasil e os brasileiros tenha sido durante sua estada na Europa (França, Itália e Espanha), mais precisamente em Paris, como adido militar e bolsista do governo mexicano entre 1919 e 1921. Foi por meio de um brasileiro, provavelmente Correia de Araújo, pintor carioca, que Siqueiros foi apresentado à Picasso.

Desde esse momento Siqueiros entendia que arte e política caminhavam juntas. Essa vinculação ficou explicitada desde cedo pelo manifesto redigido por Siqueiros "Tres llamamientos de orientación actual a los pintores y escultores de la nueva generación de América", datado de 1921 e publicado em Barcelona. Dois anos depois, ele ingressava no Partido Comunista mexicano, tornando-se rapidamente uma de suas principais lideranças. Em 1929, por conta dessa vinculação, participou como secretário geral da Confederación Sindical Unitaria do Congresso Sindical Latinoamericano, realizado em Montevidéu. Na sua volta ao México, ficou preso na cidade de Taxco. Voltou à América do Sul passando por Buenos Aires e Montevidéu em 1933. Nesse mesmo ano, proferiu algumas conferências em Buenos Aires a convite de Victoria Ocampo e, a seguir, passou rapidamente pelo Brasil. Visitou São Paulo, onde proferiu uma conferência no Clube de Arte Moderna (CAM) e onde estabeleceu contato com vários intelectuais brasileiros, entre os quais Oswald de Andrade.

Reproduzo aqui as recordações de Flávio de Carvalho (1939), um personagem dos mais atuantes no meio cultural paulista daquele momento, sobre a palestra de Siqueiros no CAM. Embora um pouco longa, é muito loquaz e uma excelente descrição do impacto das ideias do pintor mexicano em terras paulistas.

Entre os acontecimentos mais interessantes do Clube se destaca a palestra do pintor mexicano David Alfaro Siqueiros. Siqueiros fez parte do grupo de renovação mexicana, o grupo de Rivera (antes de brigar com Rivera)... aquele grupo que pintava afrescos nas paredes externas da cidade do México.

Tipicamente artista, alto, mestiço, cabeleira negra, era - coisa pouco comum entre os artistas - grande orador, falava horas intei- 
ras com um improviso vigoroso e imaginativo e sem cansar o público... Siqueiros empolgava a assistência, formava um verdadeiro campo magnético no auditório e conservava esse campo magnético com o mesmo potencial durante as horas que duravam as suas orações, nunca em nenhum momento esmorecia, como costuma acontecer com os altos e baixos do orador normal.

Ele era mais exuberante como orador que como pintor, tinha-se a impressão que a sua oratória emanava da sua pintura, era uma consequência e uma continuação da pintura, vinha como o sublime acabamento da pintura. Ele não falava para explicar mas sim para acabar uma coisa que ele havia começado plasticamente. A oratória era em Siqueiros o fim de uma luta, o último ato de um espetáculo, mas evidentemente uma "finale" que não podia ser expressa plasticamente, que só era visível em palavras.

Siqueiros era político e o seu vigor em oratória provinha das suas condições políticas; o ambiente irreverente, irresponsável e livre do Clube o inspirava. Ele sentia-se bem entre nós.

As suas ideias políticas só uma ou outra vez afetaram a cor e a forma dos seus argumentos - coisa rara entre elementos radicais.

A forma da sua oratória se parecia com a forma da sua pintura: grande imaginação, grande exuberância, dantesca em tonalidade, forte e definida em emoção.

A assistência imóvel hipnotizada, sem o menor sinal de cansaço, escutou Siqueiros durante quatro horas.

Depois de São Paulo, Siqueiros seguiu para o Rio de Janeiro, onde passou rapidamente para proferir outra conferência. Teve a oportunidade de passear pela cidade: caminhou pela Avenida Copacabana, foi ao bairro do Mangue, comprou um exemplar de Cacau, de Jorge Amado, e bebeu em um botequim.

$\mathrm{Na}$ conferência foi apresentado por Di Cavalcanti e falou por duas horas. Segundo o editor da revista Rumo, "Começou a falar e virou mil [...] No fim as ideias dele estavam rodando dentro da cabeça de cada um, feito transfusão de sangue".

A revista publica neste mesmo número um artigo síntese de sua conferência denominada "Revolução Técnica da Pintura". Curioso 
que entre os redatores dessa revista temos Carlos Lacerda - então comunista - em conjunto com Evandro Lins e Silva e Moacyr Werneck de Castro. Como mais um exemplo da circulação de artistas e ideias políticas nesse período, no ano seguinte a Nueva Revista (já referida), em Buenos Aires, publica um artigo de Antonio Berri denominado "Siqueiros y el arte de masas" (Berri, 2006, p.25), que discute a relação Arte e Política presente em especial nos trabalhos de Siqueiros.

Talvez uma das marcas mais indeléveis da passagem de Siqueiros em terras brasileiras tenha sido deixada em Oswald de Andrade. $\mathrm{Na}$ década de 1930 temos um engajamento político de Oswald. Essa postura militante vai se refletir em sua proposta de uma "prosa de tese", consubstanciada em seu romance experimental Marco zero. Obra de caráter monumental realizada na forma de colagem ou de montagem cubo-futurista, foi produzida entre 1933 e 1945 e permaneceu inconclusa. Entre os volumes projetados estavam Revolução melancólica e Chão. A proposta dessa experiência era denominada de "romance mural" e nela já podemos vislumbrar as influências de Siqueiros e Diego Rivera. Essa obra seria uma crítica à burguesia paulista, a essa aristocracia em decadência devido à especulação financeira pós-crack da Bolsa de Nova Iorque e Revolução Constitucionalista.

O que mais nos chama a atenção no romance é o debate sobre a teoria da arte, quando procura estabelecer uma discussão teórica e estética entre dois personagens que seriam Jack de São Cristovão, um arquiteto (muito provavelmente Flávio de Carvalho) e Carlos de Jaert, um pintor (possivelmente Lasar Segal) a propósito de uma conferência proferida no CAM.

Em outro trecho do romance mural Chão, Oswald reconhece: "Hoje, dez anos depois dessa cena ficcional que expressava o que sucedia aqui em São Paulo em 1934, as sugestões de David Alfaro Siqueiros tomam corpo". Diz que "o mestre mexicano acaba de criar um movimento contrário ao modernismo estético e polêmico, indicando a necessidade cada vez maior de dar-lhe um sentido social e político à arte contemporânea". Para Oswald, a solução técnica dos murais resolve o dilema de encontrar uma representação artística coletiva e socializante, tanto plástica como escrita, sem a qual não teria criado o romance mural. 
Essas teorias já haviam sido colocadas em prática por Siqueiros nos trabalhos realizados em Buenos Aires, de onde acabava de vir. Lá, procurou pela primeira vez aliar pintura e arquitetura no que ficou conhecido como Ejercicio plástico organizado por ele e uma equipe que incluía o argentino Antonio Berni. Ambos vão trabalhar na abóboda de um café na periferia de Buenos Aires. Tal "ejercicio" estava presente também no romance experimental de Oswald, em que aparecia tanto a retórica social, e diríamos socialista, como certo teor futurista, devido a suas técnicas de expressão, como a "descontinuidade cênica”, ou sua prosa cinematográfica com tons da pintura, do cinema e das discussões da época, como bem assinalou Antônio Cândido (1945). Sem dúvidas que nesse tom futurista de "arte ação" Siqueiros também compartia do uso de planos fílmicos e da fotografia.

Com toda certeza as propostas estéticas e políticas de Siqueiros calaram fundo no modernista. No Brasil, quem vai seguir esse caminho da chamada segunda dentição da antropofagia serão Tarsila do Amaral, com seus quadros A negra e Abaporú, e, depois, a pintura de Candido Portinari, de Di Cavalcanti e, é claro, de Lasar Segal.

Enquanto isso, Siqueiros, nos anos finais da década de 1930, participa da Guerra Civil Espanhola e, em seu retorno ao México, continua com seus experimentos plásticos. Preso novamente, exila-se no Chile, com a ajuda de Pablo Neruda, onde permaneceu até 1943. Durante esse período, viajou para o Peru, o Equador, a Colômbia, o Panamá e Cuba. Posteriormente retornou ao seu país, onde executou importantes murais.

$\mathrm{Na}$ fase seguinte, a partir do final da década de 1940 e início da de 1950, continua com seus experimentos e inicia seu mural mais conhecido, denominado Do porfirismo à Revolução, no Castillo de Chapultepec, transformado posteriormente em Museu Nacional de História. Essa obra foi interrompida por diversas vezes, inclusive por suas prisões. ${ }^{8}$ Desse período localizei uma série de correspondências recebidas e enviadas por Siqueiros para várias persona-

8 Para mais informações, veja o trabalho de Vasconcellos (2007). 
lidades do meio cultural e político brasileiro e para instituições de nosso país ao longo dessa década e da seguinte, quando participa com grande sucesso na III Bienal de São Paulo, em 1955, comprovando a manutenção de uma rede intelectual entre Brasil e México (Barbosa, 2008).

No Brasil, talvez as primeiras manifestações da emergência de uma consciência política na cultura visual tenham sido as pinturas Operários e segunda classe, de Tarsila do Amaral, expostas no Palace Hotel do Rio de Janeiro em 1933. Di Cavalcanti escreve, no jornal Diário Carioca, uma crítica elogiosa dessas obras de Tarsila e publica o álbum A realidade brasileira, em 1930, em que por meio de 12 desenhos faz uma crítica à situação política do país. Vemos nesses desenhos ecos de George Grosz e que também podemos encontrar em Diego Rivera.
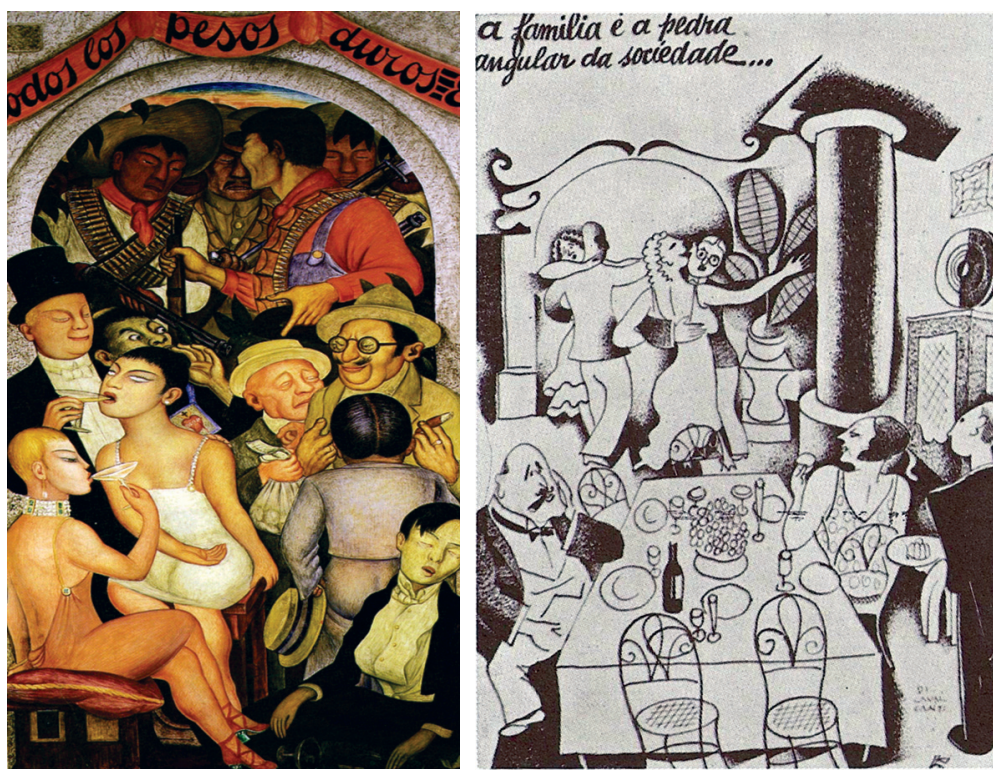

Detalhe do mural Visão política do povo mexicano, de Diego Rivera, na Secretaria de Educação Pública (México), 1923-1928. Página do álbum A realidade brasileira, de Emilio Di Cavalcanti (Brasil), 1930. 
Para citar mais alguns artistas brasileiros, vale lembrar de Quirino Camporiorito com seu retrato Operário (coleção Museu Nacional de Belas Artes, RJ) e sua natureza morta intitulada Vinte anos de início da Primeira Guerra Mundial, obra de cunho eminentemente pacifista. Posteriormente realizará obras como Hora do almoço e Aquecendo a comida aos camaradas, esta última de 1939. Não podemos esquecer também a atuação de outro artista importante: Eugênio Sigaud.

Outro movimento importante foi a fundação da revista Claridade, no Rio de Janeiro, e a criação do Grupo Zumbi, em São Paulo, ambos inspirados no grupo e revista francês Clarté, de Henri Barbusse, que terá uma congênere na Argentina, Claridad. Ainda em São Paulo, após a Semana de Arte Moderna, eminentemente de elite, surge o Grupo Santa Helena, formado por operários, ex-jogadores de futebol, pintores de parede e desempregados e que contava entre seus membros com Alfredo Volpi e Francisco Rebolo. Reuniam-se no edifício Santa Helena e discutiam, além de arte, sobre a situação política, o socialismo, o fascismo e o comunismo. Também frequentavam o grupo artistas como Manuel Martins, Clóvis Graciano, Mario Zanini, Humberto Rosa, Figuera, Penacchi e o escritor Roque De Chiaro.

Cabe um destaque à capital paulista como um centro de resistência ao integralismo, que tinha, também na cidade, seu líder Plínio Salgado. São Paulo era só agitação e ponto nevrálgico dos acontecimentos políticos. A cidade era dividida entre a elitista Higienópolis e os proletários do Brás e do Cambuci, sofreu uma intervenção com o governo de Getúlio Vargas e foi palco da Revolução Constitucionalista, em 1932. É na capital paulista que teremos um dos centros dos embates políticos e culturais do país. Foi palco dos choques entre comunistas e socialistas na Praça da Sé, assim como a Cidade do México foi cenário de conflitos semelhantes registrados em fotografias, como os ocorridos em 1935 entre os Camisas Douradas, grupo fascista mexicano, e militantes comunistas vinculados ao Sindicato dos Taxistas comandados por David Alfaro Siqueiros. A pauliceia, assim como a grande Tenochititlán, por serem grandes 
centros industriais e do operariado, foram lócus privilegiados da iconografia política da época.

No plano cultural, o Clube de artistas modernos, já citado anteriormente e tendo à frente Flávio de Carvalho e seu Teatro experiência, foi o núcleo mais atuante, com exposições da obra de Kaethe Kollwitz (que tanto marcou essa geração), de Tarsila do Amaral e outras, além das diversas conferências: Tarsila falando sobre Arte Proletária na União Soviética; Mário Pedrosa, sobre Kollwitz; a conferência de Caio Prado Jr. sobre a União Soviética, na qual, tamanho era o público, que ficou gente de fora até a distância de 150 metros; de Jorge Amado; além da já citada conferência de Siqueiros.

No Rio de Janeiro surge outra revista, Movimento - Revista do Club de Cultura Moderna, contando entre seus membros com Jorge Amado, Santa Rosa e outros. A propósito, outra figura de suma importância era Mário Pedrosa. Militante político extremamente atuante, foi crítico de arte e organizador de exposições, um verdadeiro mediador cultural. Escreveu, ainda na década de 1930, artigos sobre a arte latino-americana e os muralistas. Posteriormente foi um dos idealizadores do Museu da Solidariedade.

Não podemos esquecer a contribuição de Lasar Segal (18911956), principalmente de suas gravuras, como a série sobre as prostitutas do bairro do Mangue, no Rio de Janeiro. Na segunda metade dos anos 1930 desponta a produção de Candido Portinari. Após uma primeira fase, o artista de Brodósqui passa a utilizar a pintura mural. Se em um primeiro momento ele não tinha conhecimento da experiência mexicana, logo em seguida interessa-se muito pelos muralistas, assim como Di Cavalcanti.

\section{Considerações finais}

Em que pese as dificuldades de comunicação, ocorreu uma circulação de projetos e ideias políticas e culturais entre Brasil e México por meio de redes de sociabilidade estabelecidas entre ar- 
tistas e intelectuais. Tanto a crítica à burguesia e à igreja - e aos seus símbolos - quanto a utilização dos operários e dos símbolos de seus respectivos movimentos políticos, no Brasil e no México, foram recorrentes. No país asteca destacam-se as figuras do índio, do mestiço e do camponês, todos muito mais presentes que no Brasil. A crítica ao fascismo e ao nazismo também era muito forte em ambos os países, assim como a abordagem do tema da Guerra Civil Espanhola.

Exposições individuais ou coletivas de artistas mexicanos, brasileiros, latino-americanos e europeus participaram de um processo de circulação e internacionalização da cultura moderna que se intensificou nas décadas de 1920 e 1930. Viagens e exílios desejados ou forçosos constituíram um espaço de intercâmbios, contaminações, apropriações e conexões e ajudaram a elaborar a cultura visual da época. Como afirmou Diana Wechler (p.29), "pôr em evidência o alto grau de circulação da informação sobre este e outros processos da arte moderna em diferentes latitudes" refuta, em parte, as afirmações clássicas não só da historiografia artística como da histórica e coloca em suspensão as afirmações de desinformação e isolamento em que viviam os artistas e intelectuais latino-americanos.

A intensidade desses intercâmbios de ideias políticas e estéticas entre um espaço e outro que esboçamos acima não confirma essas afirmações. Nesse sentido, as revistas culturais, com seus avanços técnicos e de reprodução visual, foram elementos de aproximação e de construção dos imaginários políticos. Nos anos 1920 e 1930 existia uma forte consciência internacional tanto dos movimentos artísticos modernos como dos processos políticos. Nesses anos o debate sobre a relação entre arte e política e a autonomia artística colocava a cultura visual em um terreno de disputa e de embates políticos.

Pretendemos continuar investigando esses repertórios visuais para perceber como ocorreram recepções, apropriações e ressignificações levadas a cabo por um grupo de artistas que possibilitou a construção de uma cultura visual e de um imaginário político na América Latina, em especial no Brasil e no México. 


\section{Referências bibliográficas}

AMARAL, A. Arte para quê? A preocupação social na arte brasileira 19301970. São Paulo: Studio Nobel, 2003.

ANDA ALANÍS, E. X. de. La arquitectura de la Revolución Mexicana: corrientes y estilos em la década de los veinte. México: UNAM/Instituto de Investigaciones Estéticas, 2008.

BAJAC, Q.. La photographie: l'époque moderne 1880-1960. Paris: Galimard, 2005.

BARBOSA SÁNCHEZ, A. Rotofoto, humor e ironía periodística. In: ELIZALDE, L. (Coord.). Revistas culturales latinoamericanas 19201960. México: Conaculta/Universidad Iberoamericana/Universidad Autónoma del Estado de Morelos, 2007, p.177-98.

BARBOSA, C. A. S. A fotografia a serviço de Clio: uma interpretação da história visual da Revolução Mexicana (1900-1940). São Paulo: Editora Unesp, 2006.

Um olhar circular: diálogos americanos de David Alfaro Siqueiros. In: Anais eletrônicos do VIII Encontro Internacional da Anphlac, Vitória: Anphlac, 2008.

BENJAMIN, W. A obra de arte na era de sua reprodutibilidade técnica. In: Obras escolhidas: magia e técnica, arte e política. São Paulo: Brasiliense, 1985, p.165-96.

BERRI, A. Siqueiros y el arte de masas. In: Nueva Revista, ano1, n. 3, enero de 1935. Apud DIANA B. W. Melancolía, presagio y perplejidad los años 30 entre los realismo y lo surreal. In: Catalogo teritorios de dialogo 1930-1945. México: Patronato Del Museu Nacional de Arte/INBA, 2006, p.25.

CÂNDIDO, A. Brigada ligeira. São Paulo: Livraria Martins Editora, 1945. CARVALHO, F. de. Recordações do Clube dos Artistas Modernos. In: RASM - Revista Anual do Salão de Maio, São Paulo, 1939.

GONZALEZ MELLO, R. Diego Rivera entre la transparência y El secreto. In: ACEVEDO, E. (Coord.). Hacia otra historia del arte en México. México: Consejo Nacional para la Cultura y las Artes, 2004.

HEARTFIELD, J. Guerra en la paz. Fotomontajes sobre El período 1930 1938. Barcelona: Gustavo Gili, 1976.

MENESES, U. T. B. de. Fontes visuais, cultura visual, História Visual. Balanço provisório, propostas cautelares. In: Revista Brasileira de História, São Paulo, v.23, n.45, p.11-36, 2003.

MIRZOEFF, N. Una introducción a la cultura visual. Barcelona: Paidós, 2003. 
MONROY NASR, R. Del olor a pólvora a la luz del rascacielos: tres décadas de fotoperiodismo mexicano. In: ACEVEDO, E. (Coord.). Hacia otra historia del arte en México. México: Consejo Nacional para la Cultura y las Artes, 2004, p.170-89.

REVISTA RUMO. David Alfaro Siqueiros: Pintor revolucionário. In: Rumo, Rio de Janeiro, ano 2, n.2, jun. 1934.

SCHWARTZ, J. Vanguardas latino-americanas: polêmicas, manifestos e textos críticos. São Paulo: Iluminuras/Edusp, 1995.

SIQUEIROS, D. A. Revolução técnica da pintura. In: Rumo, Rio de Janeiro, ano 2, n.2, jun. 1934.

TENORIO TRILLO, M. O tropical Cuauhtemoc: a celebração da raça cósmica na Baia da Guanabara. In: Estudos históricos, Rio de Janeiro, FGV, 1995, p.1-32.

Artilugio de la nación moderna: México en las exposiciones universales, 1880-1930. México: FCE, 1998.

VASCONCELLOS, C. M. Imagens da Revolução Mexicana: o Museu Nacional de História do México 1940-1982. São Paulo: Humanitas/ Alameda, 2007.

WECHSLER, D. B. Melancolía, presagio y perplejidad los años 30 entre los realismo y lo surreal. In: Catalogo teritorios de dialogo 1930-1945. México: Patronato Del Museu Nacional de Arte/INBA, 2006. 



\section{4 \\ O Movimento Nacionalista \\ TACUARA E SUAS RAMIFICAÇÕES: \\ UMA ANÁLISE DE SUAS REPRESENTAÇÕES FIGURATIVAS}

María Valéria Galván ${ }^{1}$

O presente trabalho é uma breve análise do imaginário social do Movimiento Nacionalista Tacuara (MNT) e das agrupações que dele se originaram na década de 1960. Tais grupos surgiram durante o processo de instabilidade política que começou na Argentina com a queda do presidente Juan Domingo Perón após o golpe de 1955, e desapareceram com o início do terrorismo estatal, em 1976. O nome genérico Tacuara refere-se a um conjunto de agrupamentos formados por jovens católicos e nacionalistas de direita. Esse grupo surgiu das reuniões de vários ex-militantes da Unión Nacionalista de Estudiantes Secundarios (Unes) e da Alianza Libertadora Nacionalista (ALN), que decidiram formar um agrupamento político adotando o nome que havia pertencido a uma publicação da antiga Unes, pois era o que melhor representava suas influências revisionistas. ${ }^{2}$ Desse modo, o MNT iniciaria sua militância defendendo as posições do ensino católico durante os conflitos gerados

1 Mestre em Sociologia da Cultura e em História pela Universidade Nacional de La Plata.

2 O revisionismo constituiu uma corrente política e historiográfica nacionalista que inverteu a clássica interpretação liberal do passado argentino e dessa forma revalorizou personagens tais como os caudilhos federalistas do século XIX. 
por uma lei do presidente Arturo Frondizi, a qual concedia o status de universidade a instituições privadas.

Mais tarde, com o ingresso de militantes simpatizantes peronistas no MNT e com a declarada intenção da direção do movimento de aproximar-se do peronismo para cooptar as bases sociais deste, a frágil trama ideológica de características direitistas, antissemitas e nacionalistas que sustentava suas práticas iria se dissolvendo ao ritmo dos acontecimentos políticos da tumultuada década de 1970 . Assim, surgem, em 1960, a Guardia Restauradora Nacionalista, em 1961, o Movimiento Nueva Argentina, e, em 1963, o Movimiento Nacionalista Revolucionário Tacuara (MNTR).

A primeira dessas cisões deveu-se a uma radicalização das tendências direitistas e antissemitas de um setor seguidor do primeiro mentor do MNT, o sacerdote integrista Julio Meinvielle. O segundo grupo foi assimilado pelo sindicalismo peronista, depois das tentativas fracassadas do MNT de nele se infiltrar. Por fim, o MNRT separou-se do MNT devido a conflitos de poder no interior do grupo original e a dissidências ideológicas originadas pelas influências do peronismo de esquerda e da Revolução Cubana. Apesar das diferenças entre os grupos, a opinião pública da época assimilava todos sob um nome que os englobava: Tacuara.

De qualquer maneira, as diferenças entre o MNT, a GRN e o MNRT não chegaram a obscurecer os muitos pontos de contato entre eles. É principalmente por meio de suas próprias produções discursivas que se podem rastrear traços em comum entre os agrupamentos, tanto nos aspectos ideológicos e pragmáticos como nos identitários. Nesse sentido, este trabalho vale-se do conceito de discursos sociais ou configurações espaço-temporais de sentido (Verón, 1996) para analisar, com o auxílio do método iconológico de Warburg e Panofsky, ${ }^{3}$ as representações figurativas dos agru-

3 Esse método consiste em estabelecer parentescos e filiações entre elementos de fenômenos figurativos diversos e distantes, sob o pressuposto de que existe uma única trama secular da civilização ocidental. Nesse sentido, a sobrevivência (Nachleben) das denominadas Pathosformeln ou constantes iconográficas 
pamentos Tacuara presentes em suas revistas, Ofensiva do MNT (1962), Tacuara. Vocero de la revolución nacionalista (1964) e Barricada (1963), do MNRT, e Mazorca4 (1966, 1968 e 1969), da GRN. Comparativamente, também é analisado um jornal da Unes: Tacuara. Vocero oficial de la UNES (1945 e 1946).

\section{Principais diferenças e semelhanças entre as publicações}

A distância temporal entre as publicações e suas diversas origens explica, em geral, algumas diferenças de estilo e de temáticas e a variedade dos motivos iconográficos utilizados, particularmente nas folhas de rosto. As figuras de águias ou condores das capas da Ofensiva, assim como os motivos da cruz-de-malta, a espada e a ausência de perspectiva, remetem às influências da heráldica, dos fascismos europeus e do catolicismo. Apesar de nos primeiros anos a bagagem ideológica dos jovens membros do MNT não ter sido homogênea, houve casos de verdadeiros fanáticos do nazismo alemão e do fascismo italiano. A capa de Barricada, publicação do MNRT' sugere o caráter crítico e revolucionário desse agrupamento, tanto no estilo do desenho, que teria sido copiado do artista plástico argentino Ricardo Carpani, como no motivo do

(que poderiam ser traduzidas como fórmulas, vetores ou elos de emotividade que possibilitam a conivência de diferentes níveis de racionalidade) esclareceria, em última instância, as experiências básicas da vida social na cultura ocidental. Esse método, instrumentalizado por Erwin Panofsky, consiste em três níveis de análise dos fenômenos figurativos: o nível pré-iconográfico ou meramente descritivo, o nível iconográfico ou dos significados convencionais, e o nível iconológico propriamente dito ou dos princípios culturais "subjacentes”. Sobre este tema, ver Ginzburg (1989; 2003); Francastel (1970); Gombrich (1983; 1997); Burucúa (2002; 2006); Burke (2005); Saxl (1989) e Warburg (2005).

4 O termo Mazorca designava as forças parapoliciais que reprimiam os opositores ao governo do caudilho Juan Manuel de Rosas na Província de Buenos Aires, entre 1829 e 1852. 
punho fechado. Também se percebe nessa figura um marcante contraste entre o projeto bem austero e moderno da parte do texto e a expressividade da imagem do logotipo. Desde sua separação do MNT original, em 1963, essa organização já havia deixado de lado as palavras de ordem e os motivos antissemitas, anticomunistas e fascistas, nostálgicos da velha ordem. Por outro lado, Mazorca, órgão de difusão da Guarda Restauradora Nacionalista, separada precocemente do MNT (1960), explicitou seu caráter ultraconservador e revisionista por meio da marcante recorrência de motivos e lemas criollistas, revisionistas, fascistas, anticomunistas e antissemitas não observados em outras publicações do MNT ou do MNRT. O contraponto desses parâmetros, por sua vez, esclarece as diferenças programáticas, ideológicas e identitárias de cada um desses grupos.

Nesse sentido, apesar de a imagem ser, em geral, relegada aos logotipos das folhas de rosto, nelas se condensavam elementos identitários e ideológicos muito recorrentes. Essas influências remetiam, em muitos desses casos, ao falangismo espanhol e ao nazismo. Entretanto, em relação a esses movimentos, o uso da imagem para o Tacuara caracterizou-se por ser menos sofisticado, mais intuitivo e com pouco rigor artístico. Tais atitudes mostram que, apesar de um destacado amadorismo no manejo das imagens, havia uma preocupação geral em aproveitar sua imediatez e capacidade de comunicação.

Por outro lado, as ilustrações desses órgãos de difusão reconhecem filiações diretas com o estilo da historieta e da ilustração das décadas de 1950 e 1970 na Argentina. A chamativa recorrência do estilo da historieta na iconografia justifica a homogeneidade e juventude dos membros dos agrupamentos, influenciados pelo comic, a literatura de aventuras, e uma particular admiração pelas figuras heroicas. Isto é particularmente notório em Mazorca e Tacuara, da Unes, nas quais os traços e o uso das sombras e das linhas guardam certa semelhança com os desenhos do comic argentino de 1950 a 1960. A opção por esse estilo e por esse tipo de suporte genérico nas publicações do Tacuara poderia ser explicada pela juventude de 
seus membros, por sua escassa disponibilidade de recursos técnicos ou por sua admiração quase infantil pelas "figuras heroicas".

Os militantes do MNT eram formados por valores que os predispunham a ser protagonistas e condutores de um processo revolucionário. Essa formação era inculcada basicamente por meio de exemplos heroicos junto a um profundo misticismo católico que preparava os "futuros heróis" para dar a vida por uma causa superior (Orlandini, 2008, p.195-6). A heroicidade é o elemento central das histórias em quadrinhos. $\mathrm{Na}$ verdade, como recorda Roberto Bardini (2002) (ex-militante tacuarista) em seu livro, a infância e a adolescência precoce de muitos deles foram marcadas tanto pela leitura das histórias de aventura relatadas por Joseph Conrad, Emilio Salgari e Jack London como pelas revistas que marcaram o auge da criatividade e da difusão das revistas em quadrinhos argentinas: Misterix, Hora Cero e Frontera. ${ }^{5}$

Por outro lado, os textos que acompanham essas ilustrações apresentam, em geral, um enunciador objetivo e pedagógico, cuja distância em relação ao leitor estreita-se diante dos apelos a uma "sensibilidade nacionalista" comum. Além disso, as diferenças entre as publicações dificilmente são rastreadas no plano da enunciação, tanto dos títulos como dos corpos de texto.

5 "Misterix" aparece pela primeira vez na revista Salgari, na década de 1940. Posteriormente, teria sua própria publicação, na qual Héctor Germán Oesterheld apresentaria, junto com Hugo Pratt, "El sargento Kirk”. A historieta tratava de um sargento do oeste longínquo que desertava depois de presenciar um massacre de índios e tornava-se um acérrimo defensor da causa indígena. Hora Cero, cuja principal historieta era "Ernie Pike", tinha como tema a Segunda Guerra Mundial por meio das crônicas imparciais de um correspondente de guerra. Por sua vez, a principal história de Frontera seria "Ticonderoga", que desenvolvia os acontecimentos da batalha de Ticonderoga durante a Guerra de Independência dos Estados Unidos. Estas duas últimas foram as primeiras publicações de Oesterheld com sua editora Frontera, e ali iriam participar os ilustradores de maior prestígio da época: Solano López, Carlos Roume, Alberto Breccia, Ivo Pavone, Hugo Pratt, Daniel Haupt, Jorge Moliterni e Arturo del Castillo, entre outros. O estilo dessas historietas de aventura não pode negar as influências das obras literárias de Conrad, Melville e Stevenson (Perez Edía, 2003). 


\section{Capas}

Ofensiva, Tacuara (Unes), Tacuara (MNT), Barricada e Mazorca apresentam a águia, o condor, a cruz, a espada, a cruz-de-malta e a lança feita de bambu - material também conhecido como taquara ${ }^{6}-$ em suas capas e contracapas. As capas de Ofensiva (Figuras 1 e 2) apresentam quatro desses elementos. Em uma delas, uma águia bicolor, com três cruzes-de-malta no peito, encontra-se de frente e com as asas abertas, segurando uma corrente entre suas patas. A seu lado podem-se observar as letras do movimento, "MNT", atravessadas por uma cruz e uma espada, e, por cima da composição, o nome da publicação em letras góticas. Outra capa apresenta uma águia (ou condor) que sobrevoa um globo terrestre, em cujo horizonte levanta-se a cruz-de-malta no lugar do sol nascente. Aqui as letras do MNT encontram-se do mesmo lado, mas a espada e a cruz já não as atravessam e são colocadas no lado oposto. Do mesmo modo, podem-se ver os logotipos das publicações Tacuara, voz oficial da Unes (Figura 3), Tacuara, voz da Revolução Nacionalista (Figuras 4 e 5) e Barricada (Figura 6), cujas letras são formadas por lanças feitas de bambu. Em uma delas, as lanças encontram-se coroadas por um livro e, sobre ele, uma tocha, enquanto na seguinte, a lança é segurada por um rude punho fechado. Por fim, as folhas de rosto e as contracapas de Mazorca recuperam, mais tardiamente, a importância da cruz-de-malta e do condor, que já substitui com total conviç̧ão a figura da águia (Figuras 7,8 e 9).

Considerando o nível iconográfico da análise dessas figuras, é possível afirmar que existe uma relação entre a águia e o emblema do antigo Sacro Império Romano-Germânico (tão explorados pela propaganda nazista) com o escudo franquista. A ave foi substituída depois pela figura de outra, o condor, que sintetiza o caráter local com as qualidades da águia. Por outro lado, o estilo gótico das letras "MNT", no qual está escrito o nome da revista Ofensiva nas pri-

6 Termo tupi, sinônimo de bambu, que busca afirmar o sentido nacionalista do movimento. 
meiras figuras, remete o espectador (assim como a ausência de perspectiva da águia na Figura 1) ao mundo medieval - e com isso ao predomínio do cristianismo, da sociedade hierárquica, dos valores guerreiros -, mas também à tipografia gótica usada pelo nazismo.

Do mesmo modo, a espada e a cruz remetem ao mundo medieval hispânico - que sugere as ideias de ordem e harmonia social -, embora também representem o espírito dos nacionalistas argentinos de 1930 que esses grupos pretendiam continuar. A cruz-demalta é uma referência explícita à ordem dos cavaleiros cruzados de Malta, e as lanças que formavam a palavra "Tacuara" remetem às lanças utilizadas pelos exércitos federalistas, conhecidos como "montoneras", do século XIX.

Enquanto o livro e o punho são dois objetos figurativos que indicam outro dos componentes identitários dos grupos Unes e MNT (estudantes e lutadores, respectivamente), os raios que a chama lança sobre o livro (Figura 3) encontram-se dispostos de tal modo que se assemelham às cinco flechas unidas pela lança no emblema da Falange espanhola (Figura 10). Além disso, em Estudio y Lucha, outra publicação da Unes, o logotipo situado na parte superior da capa apresenta uma composição com três lanças tacuara dispostas da mesma forma (Figura 11). Reminiscências desse logotipo também podem ser identificadas em edições tardias de Mazorca e Barricada (Figuras 12 e 13).

É de interesse para esta análise o fato de que todas essas composições, ao se encontrarem sistematicamente na capa dos números de Ofensiva, Tacuara (MNRT), Mazorca e Barricada, eram uma espécie de "carta de apresentação" do grupo. Desse modo, por meio do uso dessas imagens, buscava-se sintetizar a identidade do grupo e o caráter da publicação. Assim eram reconhecidas explicitamente filiações e simpatias que muitas vezes não eram percebidas com tanta clareza na análise de seus textos: falangismo, nazismo, nacionalismo, catolicismo militante e revisionismo.

Por outro lado, a recorrência de alguns temas, motivos e constantes iconográficas nessas publicações permitem observar a predominância comum da temática criollista. 


\section{Predominância do criollismo}

Segundo afirma Juan Esteban Orlandini (2008) em seu livro Tacuara, a lança que em geral acompanhava a figura do gaúcho foi utilizada pela primeira vez como motivo principal na Tacuara da Unes (Figura 3) na década de 1940. Presente na capa anteriormente analisada, teria representado a rebeldia e a luta do povo oprimido. Como afirma esse autor, o MNT teria ecoado essa tradição, adotando o símbolo da taquara para representar seu ideal do "povo armado na luta por sua liberdade”. Entretanto, a adoção do imaginário gauchesco em geral e da figura do gaúcho em si - que, a propósito, foram os elementos em comum mais recorrentes nas publicações dos diversos agrupamentos derivados da velha Unes teve também outras implicações.

A influência do revisionismo histórico nas publicações analisadas é notória. Essa corrente, que - como afirma Halperin Donghisurgiu no início do século XX como um projeto ao mesmo tempo historiográfico e político, inspirou-se principalmente na crítica à democratização política e ao modo de inserção do país no mundo, para o qual buscou o apoio da história. A corrente revisionista argentina pode se dividir em várias fases, mas um elemento nelas recorrente é a nostalgia da época de Rosas, vista como o "paraíso perdido". 7

7 Seguindo a classificação realizada por Alejandro Cattaruzza em seu trabalho "El revisionismo: itinerario de cuatro décadas" (2003a), podem-se distinguir quatro etapas no revisionismo histórico argentino, segundo as diferenças nas práticas e estratégias dos intelectuais revisionistas em relação ao campo político e historiográfico argentinos no transcurso do seu desenvolvimento. Em primeiro lugar, Cattaruzza caracteriza aquela que percorre os anos entre o Centenário e 1929, à qual seguem os períodos de 1930-1945 e 1945-1955, e finalmente aquela entre 1955 e 1973. Durante as primeiras décadas do século XX, o revisionismo argentino caracterizou-se, principalmente, por levar adiante uma propaganda de "revisão" da história oficial, sob o prisma dos esquemas de interpretação maurrasianos do passado. A segunda etapa do revisionismo teve início com a idealização por parte da nova geração de intelectuais revisionistas de um período do passado argentino em particular: o governo de Rosas. Em um primeiro momento, identificou-se o governador de Buenos Aires com o demagogo aniquilado, Yrigoyen, quadro no qual Uriburu 
Nesse sentido, os integrantes do Tacuara identificavam-se com os discursos e ideais desse revisionismo e aderiam, particularmente, à identificação entre Rosas e Perón. Assim, suas práticas e discursos empenhavam-se em destacar sua oposição à fé sarmientiana ${ }^{8}$ na civilização e no liberalismo da história oficial argentina.

O imaginário revisionista adotado por esses agrupamentos caracterizou-se pela centralidade da figura de um gaúcho heroico que, representando o povo armado, se opunha radicalmente ao gaúcho despojado de qualquer atributo épico descrito por Sarmiento. Do mesmo modo, é recuperado e recebe um novo significado o conceito de "barbárie" (Marty, 1996), que Tacuara reivindicava em oposição ao de "civilização", que teria um caráter europeizante. Com isso, por sua vez, o agrupamento dava um novo significado à data de 11 de setembro - aniversário da morte de Domingo Faustino Sarmiento -, agora por eles denominada como Dia da Barbárie em homenagem ao caudilho riojano Facundo Quiroga. ${ }^{9}$ Nesse sentido,

(figura política que representava os interesses do grupo de revisionistas) estaria representado pela figura de Lavalle, inimigo de Rosas. Entretanto, o fracasso de Lavalle (confundido com o do próprio Uriburu), atribuído ao seu grupo mais próximo, suporia a demonização dos unitários. A partir daí, o crescimento das simpatias por Rosas seria inevitável (Halperin Donghi, 2005). A terceira etapa começa com a chegada do peronismo ao poder. Nesse período, os revisionistas acreditaram ver realizado seu projeto político; entretanto, como recorda Halperin Dongui (idem, p.30), "o novo regime político não ia receber com efusão o aporte revisionista: se o seu triunfo debilitou o influxo daquela que os revisionistas chamavam de história oficial nos centros oficiais de estudos históricos, não se traduziu na integração da visão revisada do passado argentino que da Argentina propunha o novo oficialismo...". Nesse período, os ares revisionistas estavam também excluídos do imaginário peronista, ou seja, da propaganda estatal e dos manuais e programas escolares, entre outros (Cattaruzza, 2003a). Por causa disso, os revisionistas viram-se reduzidos ao seu papel de historiadores e seu próprio projeto político teve de ser congelado. Por fim, a partir da derrocada do governo peronista, os opositores do peronismo começaram a promover uma suposta equivalência entre os dois líderes. Alguns anos depois, o revisionismo seria finalmente adotado pelo peronismo (tanto de direita como de esquerda), assumindo definitivamente um novo significado.

8 Em referência a Domingo Faustino Sarmiento.

9 Ver Mundo Israelita, 15 de setembro de 1962; Marty (1997); Gutman (2003). 
eram usuais os agravos a bustos de Sarmiento, a quem viam como o pai dos ideais liberais de progresso e civilização, ${ }^{10}$ assim como também os agravos contra outros símbolos liberais, como, por exemplo, representações diplomáticas do Reino Unido. ${ }^{11}$ Outras datas importantes para o agrupamento foram o dia 20 de novembro, Dia da Soberania Nacional, ${ }^{12}$ e o dia 20 de junho, Dia da Bandeira, quando se realizavam atos comemorativos e desfiles nos quais não faltavam a exibição de cruzes, aclamações, uniformes, a distribuição de panfletos e a saudação romana. ${ }^{13}$

Entretanto, a assimilação do imaginário criollista da figura do gaúcho apresentada pelo MNT, pela GRN e pelo MNRT e sua referência ao popular é anterior às correntes revisionistas. Em 1870, diante da preocupação pela "presença estrangeira" no país, tentou-se, a partir do poder político, recorrer a festas e monumentos pátrios para obrigar o nascimento de um culto à pátria então considerado insuficiente (Cattaruzza, 2003b). Posteriormente, teve grande sucesso a publicação do poema El gaucho Martin Fierro. Em 1880 foi publicado Juan Moreira, a história de um gaúcho levado ao crime pelas circunstâncias de sua situação. Aos olhos do povo, Juan Moreira converteu-se em um herói rebelde que luta contra as injustiças e os excessos do poder político (ibidem). Nesse período, "na produção dos grupos ilustrados [...] os elementos criollistas se encontravam expurgados ou eram convertidos em motivo de escárnio" (idem, p.227). Não obstante, a relação com a figura controvertida foi mudando de rumo no correr do tempo. Assim, no início do séc. XX,

10 Ver Comisión Provincial por la Memoria (ex-archivo DIPBA), Legajo 15456, Mesa Referencia; Fondo CEN, Caja 1424; La Razón, 20 de fevereiro de 1963; La Prensa, 2 de abril de 1964.

11 Comisión Provincial por la Memoria (ex-archivo DIPBA), Legajo 1352, carpeta Daños, Mesa "DS".

12 No dia 20 de novembro de 1964, um grupo de afiliados ao MNT - sob a liderança de Juan Mario Collins - pendurou três bandeiras no Cabildo, com o objetivo de comemorar o Dia da Soberania Nacional, enquanto seus companheiros aclamavam fora "San Martin-Rosas-Perón” (Gutman, 2003).

13 Ver La Luz, 5 de julho de 1963. 
no clima do Centenário, foram alguns homens de letras que resgataram Martin Fierro como poema nacional, com argumentos [...] que deslocavam o foco de atenção de uma questão de conteúdo - a rebeldia frente às injustiças - para uma vinculada à forma - a originalidade de um idioma e de um gênero nativo. Paulatinamente, foram caindo no esquecimento alguns dos aspectos do poema que, na sua época, haviam sido considerados os mais perigosos para a ordem social. Estas transformações foram uma das condições de possibilidade para que, no final dos anos trinta, o Estado reconhecesse tardiamente aquela inclinação popular para o criollismo. (idem, p.260)

A direita - política e cultural - da década de 1940 também retomou a figura com novo significado do gaúcho e, para servir ao seu projeto ideológico, caracterizou-a como vítima da usura judia, do imperialismo inglês e do catolicismo (idem). Dessa maneira, tanto a partir desses setores como do Estado recuperou-se uma imagem do gaúcho completamente alheia ao criollismo.

Segundo a análise de Gené (2005), durante os anos do primeiro peronismo as iconografias do gaúcho identificaram-se com a figura do "peão rural". As representações figurativas do gaúcho nesse período não diferem muito daquelas do período anterior. Por meio de imagens gráficas superpostas com as silhuetas de conquistadores espanhóis, de aborígenes ou da rainha Católica, procurava-se apresentá-lo como símbolo da tradição católico-hispânica e do "autóctone" nacional (idem). Entretanto, "o uso da figura do gaúcho não se limitou apenas àquelas ocasiões em que se devia expressar o vernáculo, a evocação das tradições autóctones, as raízes comuns. Os propagandistas do peronismo exploraram a fundo as possibilidades oferecidas pelo "símbolo da argentinidade"” (idem, p.114). Assim, por exemplo, nas imagens fílmicas e fotográficas foi apresentado um gaúcho mais associado à figura de Perón como líder. ${ }^{14}$

14 Gené cita os exemplos do filme de ficção La payada del tiempo nuevo, dirigido por Ralph Pappier em 1950, e da fotografia do boxeador César Brion, vestido de gaúcho sobre um fundo com imagens de Eva e Juan Perón, durante sua excursão pelos Estados Unidos (Gené, 2005, p.114-6). 
No Tacuara do MNT, em que se retoma a cana na folha de rosto, o gaúcho a cavalo volta a aparecer representando o povo guiado pela Pátria. Ele veste um traje de guerreiro antigo e traz o estandarte da organização (Figura 14). As características da imagem da Pátria no Tacuara remetem aqui à Pathosformel da ninfa, segundo os estudos iconográficos de Aby Warburg.

As Pathosformeln são definidas por José Emilio Burucúa (2006, p.12) como

um conglomerado de formas representativas e significantes, historicamente determinado no momento da sua primeira síntese, que reforça a compreensão do sentido do que está representado mediante a indução de um campo afetivo em que se desenvolvem as emoções precisas e bipolares que uma cultura destaca como experiência básica da vida social.

Não são outra coisa senão fórmulas recorrentes nas manifestações culturais do Ocidente ao longo da história, capazes - graças à sua condição de "vetores de emoções" - de dar conta da trama secular da cultura ocidental. Por esse motivo, sua análise exige relacionar fenômenos figurativos distantes no tempo que representem uma continuidade significativa. ${ }^{15}$ Assim, a busca exaustiva da ninfa realizada por Warburg (2005) tem suas origens na Antiguidade. O reaparecimento da Pathosformel da ninfa, com seus movimentos

15 As Pathosformeln estão sempre presentes nas manifestações culturais, apesar dos vaivens do Denkraum ou "espaço para o pensamento" (determinado por três umbrais: a magia, a religião e a ciência). Nas palavras de Burucúa (2006, p.179-80), “....as transformações do papel das artes com respeito ao Denkraum implicariam uma supremacia da dimensão transitiva das imagens e uma escassez da sua potência reflexiva, enquanto um retrocesso no sentido da magia, isto é, da diminuição do Denkraum, conduziria, talvez, a uma debilitação das determinações transitivas e a uma intensificação da imagem per se. Mas, nesses vaivens seculares, as Pathosformeln estariam sempre disponíveis e o maior ou menor peso de cada extremo da simbiose - o pathos ou a forma clara e definida - não questionaria a integridade das Pathosformeln características do que chamamos de uma tradição civilizatória". 
graciosos e joviais e suas roupas e cabelos ondulantes, no Renascimento europeu, segundo analisa Warburg, representava a emergência de um novo sujeito histórico, o burguês, jovem e dinâmico, encarregado do comércio, responsável pelo florescimento das cidades e antecessor do esplendor da política, da ciência e das viagens transatlânticas. Ou seja, a ninfa representava o dinamismo próprio da ampliação das fronteiras físicas e mentais, que havia sido em grande parte recuperado dos antigos (Burucúa, 2002). ${ }^{16}$

A ninfa continuou, assim, seu caminho, e foi também protagonista da Revolução Francesa. Como relata Peter Burke (2005), com a Revolução Francesa foram realizadas muitas tentativas de traduzir para a linguagem visual os ideais de liberdade, igualdade e fraternidade. Nesse contexto, a ninfa reencarnou na figura de Marianne, símbolo da República Francesa, cuja cabeça de série é a mulher de A Liberdade guiando o povo, de Eugène Delacroix (Figura 15).

A tradição liberal predominante na Argentina no final do século XIX continuou essa série de personificações, encomendadas a essa Pathosformel com o Corpo de Marianne. A produção figurativa liberal na Argentina é vasta e nela se destaca a figura da República Argentina, construída a partir de elementos tomados da personificação da Liberdade (por exemplo, o gorro frígio ${ }^{17}$ ). Entretanto, no caso do Tacuara, a figura da República como mulher jovem e dinâmica recebe um novo significado: ela é construída a partir de elementos que se opõem claramente à tradição liberal. Assim, deixa-se de lado a figura central da "República" e esta é substituída pela da "Pátria", que é representada por uma mulher vestida com

16 Como descreve Burucúa (2002, p.16), "em um lado e outro dos Alpes, então, esses homini novi ressuscitavam as experiências do intelecto e das experiências do intelecto e da emocionalidade de outros homens em um pretérito remoto, muito anteriores a qualquer antepassado cristão daqueles que tiveram uma memória direta mais ou menos imediata".

17 O gorro vermelho da figura francesa da Liberdade é uma versão modernizada do gorro frígio associado na época clássica com a libertação dos escravos (Burke, 2005). 
um traje de guerreiro antigo e com uma atitude desafiadora, própria do início de uma batalha. Levando em uma das mãos a espada de combate e, na outra, o estandarte do Tacuara, inicia a luta e auxilia, como um espectro protetor, um gaúcho guerrilheiro. Além disso, o texto que acompanha essa imagem poderosa afirma que

a velha do gorro frígio, filha da revolução francesa e senhora do país desde Caseros, está nas últimas: caduca, e nossa pobre Pátria, nascida para grandes destinos em constante frustração, corcoveia para tirar de cima de si esta gorda caduca, que com as rédeas na mão está fazendo com que ela faça loucas piruetas. Porque isto que estamos presenciando, que são os estertores de um regime decadente, a democracia liberal, de instituições, homens, parlamentos e partidos de um regime de sobreviventes, tem todas as características de um circo e de um sainete. ${ }^{18}$

Aqui, a imagem e as afirmações revisionistas de texto coincidem e complementam-se, sem que uma seja descrição da outra e viceversa: a figura da Pátria é representada por meio de uma mulher jovem, esbelta, forte e galharda (a ninfa), em contraposição aos elementos com os quais o texto caricaturiza a figura da República Argentina.

Esse paralelo entre as duas figuras femininas aparece também em Barricada, só que ali a figura da ninfa não está representada iconograficamente, mas o que está representado é "apresentado" de maneira explícita e, mais uma vez, acompanhado do seu oposto: "nossa juventude avança sobre as ruínas do regime caduco para plasmar a arquitetura revolucionária de uma nova Argentina, poderosa, imperial e comunitária" (Barricada, n.9, p.1). Neste exemplo, o que está condensado pela ninfa na figura anterior está dissolvido na ideia de uma juventude revolucionária, por um lado, e de uma Argentina utópica, a própria motivação da luta. Fica assim explicitada a dimensão transitiva da ninfa, enquanto sua dimensão

18 Tacuara, vocero de la Revolución Nacionalista, n.8, ano 1962 (?). 
reflexiva permanece. ${ }^{19} \mathrm{Ou}$ seja, a ninfa que desliza nas representações desses agrupamentos revela um movimento ágil, dinâmico e revolucionário que, com sua ação, procura apresentar uma imagem de Pátria, com a qual identifica-se e com a qual acredita compartilhar os mesmos atributos. Estes se opõem, por sua vez, a uma mulher envelhecida que, para eles, já perdeu sua jovialidade e seu dinamismo: a República liberal.

O atraente é que, apesar disso, a tradição liberal tão enfadonha e antagonizada por esses grupos está de alguma maneira presente (aparentemente de maneira imperceptível para o olho do Tacuara) na figura da Pátria, que assume uma forma humana e feminina graças ao auxílio da Pathosformel da ninfa. Seu contraste com a obra de Delacroix (Figura 15) - imagem não só paradigmática da Revolução Francesa e do valor da liberdade, mas também a principal das personificações dos valores liberais - contribui para a observação do parentesco. A pose é muito similar, e as duas mulheres seguram em uma das mãos a bandeira pela qual lutam e, na outra, uma arma, o que convida o observador a associar as duas imagens. ${ }^{20}$ Além disso, elas se encontram nas duas representações guiando, de um lugar elevado e por trás (quase como um espírito que luta com o povo), o elemento popular da composição: em um caso, o gaúcho guerrilheiro a cavalo; ${ }^{21}$ no outro, o rapaz. A identidade do menino de Delacroix com o povo não é uma novidade. A respeito, é necessário lembrar que, como afirma Michel De Certeau (1999_, a associação

19 A dimensão transitiva ou da representação na imagem referiria-se ao conteúdo cultural da Pathosformel em relação ao seu contexto histórico, pois a dimensão reflexiva estaria mais vinculada à emoção disparada pela própria Pathosformel (Burucúa, 2006).

20 Apesar de Marianne encontrar-se nua e a Pátria de Tacuara estar pesadamente vestida com um uniforme militar antigo, imitando a deusa Ateneia. Este, na verdade, talvez seja o único elemento figurativo que destaque a diferença entre as duas mulheres e que recorde que, enquanto uma delas remete à tradição liberal incipiente, a outra remete a um conservadorismo militar e nostálgico.

21 A presença do cavalo acompanhando o gaúcho é outra diferença importante entre as duas composições. O cavalo remete à tradição americanista dos heróis a cavalo atravessando a vastidão do continente. 
entre os dois conceitos é um lugar-comum na tradição ocidental. Entretanto, talvez seja mais interessante para esta análise o fato de que, na composição quase especular da Pátria, o lugar do menino é substituído pela figura do gaúcho.

Finalmente, na Mazorca da GRN, a figura do gaúcho entra de novo em cena pelas mãos de dois Pathosformeln. Nas Figuras 16, 17 e 18 pode-se ver gaúcho forte, heroico, valente e em pé de guerra (o gaúcho da Figura 16 é um mazorquero), tendo sempre na mão a lança feita de bambu. Trata-se da Pathosformel do herói em combate. ${ }^{22}$ Não obstante, nas Figuras 19 e 20 vê-se um gaúcho desarmado, pobre, cabisbaixo e vencido: o gaúcho que encarna a Pathosformel do sofredor. ${ }^{23}$

Essas diferenças tão radicais nos modos de representar o gaúcho da publicação e o recurso a diferentes, e inclusive opostas, Pathosformeln, em um lapso de tempo muito curto, devem-se em parte ao uso que é outorgado a essa imagem em cada composição. Nessas figuras, o gaúcho encontra-se na capa ou na contracapa da publicação, razão pela qual se pode interpretar que com a imagem procurase "representar" o caráter da publicação e a identidade do agrupa-

22 Segundo Saxl (1989), a Pathosformel do homem lutador, o homem que luta com a besta, em suas diversas versões com armas primitivas (brandindo uma maça ou um pau) ou apresentando uma disposição do corpo que o coloca em situação de caça ou de luta contra forças não humanas, nasceu na arte da Mesopotâmia com a figura de Mitras e teria alcançado sua expressão máxima nas representações gregas de Hércules. Burucúa (2006, p.188) continua a série e mostra o ressurgimento desta na arte da Shoa, encarnando neste caso os verdugos.

23 “Também a reelaboração icônica do cristianismo afetou a outra Pathosformel que encontramos na arte antiga, a do escravo, a do vencido, a do homem extenuado pelo trabalho, a servidão e a derrota, uma figura com a cabeça baixa, encurvada, que pode transmitir uma sensação de esforço, mas sempre à beira do esgotamento. Assim a vemos nos relevos históricos das colunas de Trajano e de Marco Aurélio, nos relevos da época antonina incorporados ao arco de Constantino. Os artistas cristãos da Baixa Idade Média e do Renascimento recuperaram essa Pathosformel, mas lhe outorgaram a dignidade do sofredor, da vítima que padece as injustiças do mundo e fizeram dele uma fórmula mais que apta a representar os mártires e até mesmo o próprio Jesus nas diversas instâncias de sua Paixão" (idem, p.189). 
mento responsável. Além disso, o texto que acompanha as Figuras 17 e 18 é um chamado à luta. Nesse contexto, a imagem descreve o horizonte que se busca alcançar a partir da interpelação: o herói pátrio ativo e em luta. Por outro lado, as Figuras 19 e 20 apresentam, por meio da imagem do gaúcho, um estado de crise social (da qual o gaúcho é vítima) que deveria servir como motivação para a luta, ou seja, a situação que se busca transformar.

Portanto, o uso da imagem do gaúcho busca não somente representar o povo - ao qual se deve proteger e defender -, mas também estabelecer uma continuidade entre sua luta e heroísmo pátrios e a luta do nacionalismo do século XX (Marty, 1996). Nesse sentido, em todas as publicações aqui mencionadas são dedicadas notas mais ou menos extensas aos paralelismos entre a história do século XIX e a atualidade política. Por exemplo, no artigo intitulado "Más de un siglo", publicado no número 14 de Mazorca, enfatiza-se a continuidade de um mesmo modelo político de dominação:

Mais de um século de sacrifício do povo criollo em benefício das oligarquias e dos senhores internacionais. Primeiro foi Caseros, onde perdemos a Pátria Grande e Soberana do General Don Juan Manuel de Rosas. Depois, em 1955, um povo cheio de esperanças é massacrado pelo único delito de trabalhar por uma Argentina Justa, Livre e Soberana. [...] da podridão sempre surgem vermes e aqui se destruiu a bicheira. Foram os Sarmientos, Mitres ... Sim, porque eles eram os vermes [...] Já não se chamam unitários; agora são "gorilas". Já não são apenas oligarquias portenhas; transformaramse em todas as latitudes do nosso campo convertidos em fazendeiros defensores do latifúndio. Já não são os imperialismos da "velha Europa"; estes foram superados pelo imperialismo ianque-judeu. (Mazorca, n.14, p.5)

Nesse encontro constrói-se uma relação metafórica entre os períodos mencionados, as figuras antagônicas (Sarmiento, Mitre, os antiperonistas da "Revolución Libertadora") e as figuras heroicas de Rosas e Perón. 
Como afirma Marty (1996), para o grupo Tacuara o uso do imaginário das lutas do século XIX e, principalmente, o da Argentina de Rosas, tem o objetivo de estabelecer uma linha de continuidade entre a luta contra o inimigo estrangeiro-invasor do séculos XIX e XX. O modelo de Rosas é, desse modo, retomado por Tacuara como opção política. A esse respeito, Glück (2000) afirma que

a percepção que os membros do Tacuara tinham de si mesmos era a de um grupo que estava realizando uma missão histórica, de restauração de uma ordem perdida, vinculada ao catolicismo e ao hispanismo, à qual vinculam em parte ao passado recente peronista. Justificam sua rebelião em função destas reivindicações, paradoxalmente vinculadas à ordem, que, no caso de serem cumpridas, voltaria a converter estes jovens em "modelos de obediência e acatamento aos mais velhos". Pareciam acreditar que sua vitória era irreversível.

O posicionamento central de Tacuara na cena tão cuidadosamente construída com o auxílio da mensagem revisionista contribui para se entender a razão de o grupo - como recorda Marty - não se interessar pelas particularidades históricas da vida do gaúcho, carência de interesse que, como se poderia acrescentar, compartilhavam os "criollistas" das primeiras décadas do século XX. O gaúcho simplesmente transformou-se em um ícone de redenção para o nacionalismo, enquanto sua imagem havia sido ressuscitada da desonra da narrativa sarmientina e resignificada como a morte trágica do orgulho nacional. Este último se vê reforçado pela presença da Pathosformel do lutador, neste caso com o objetivo de engrossar o panteão dos heróis trágicos de Tacuara que lutaram até a morte por sua causa. Nesse sentido, a relação do MNT, do MNRT, da GRN e da Unes com o popular, segundo mostra sua iconografia, é do tipo folclorista. Segundo a descrição de Néstor García Canclini (1988), o folclorismo define-se por apresentar os elementos folclóricos descontextualizados, despojados das referências semânticas e pragmáticas que poderiam torná-los inteligíveis. Ou seja, o folclorismo do Tacuara, manifestado nos temas e nos motivos das imagens, consiste em um uso 
meramente pictórico e conservador de elementos que representam as tradições do povo, com o objetivo de promover um projeto político nostálgico e alheio aos setores populares, baseado na reinstauração de uma ordem perdida. Nesta, o gaúcho, metáfora do povo (como se vê claramente na Figura 5), não ocupa o lugar do dirigente, daquele que conduz a batalha, como faz o militante nacionalista, o tacuara. Isso pode ser observado também nas Figuras 19 e 20, onde a Pathosformel do sofredor - que tradicionalmente tem simbolizado a vítima, aquele que sofre impotente as injustiças - representa esse gaúcho desvalido, que parece esperar a ajuda do militante nacionalista.

\section{Considerações finais}

Este trabalho teve como eixo o estudo dos discursos sociais que circularam no interior da corrente Tacuara, buscando compreender a visão que os integrantes desses agrupamentos tinham sobre o mundo e sobre si mesmos. Para isso, foram consideradas as publicações periódicas do MNT, da GRN, do MNRT e da Unes.

Como um dos traços mais significativos pôde-se observar que, entre muitas semelhanças discursivas e estilísticas presentes nas publicações editadas pelas diferentes facções do Tacuara - que remontavam inclusive ao agrupamento antecessor Unes - destacava-se uma constante principalmente temática que obscurecia suas diferenças ideológicas e identitárias. Essa constante encontra-se sintetizada pela incorporação, de teor folclorista, da figura mítica do gaúcho ao seu imaginário, e pela assimilação metafórica entre as lutas do século XIX e os objetivos do movimento nacionalista que acreditavam representar. Dessa maneira, os agrupamentos Tacuara coincidiram na tentativa de legitimar seu papel de "restauradores" de uma ordem perdida, atribuindo-se o papel de vanguarda política na condução do povo. Nesse sentido, a importância comum do folclorismo e do antiliberalismo do MNT, da GRN e do MNRT deixou em segundo plano as rupturas ideológicas e políticas que suscitaram as divisões do MNT original. 


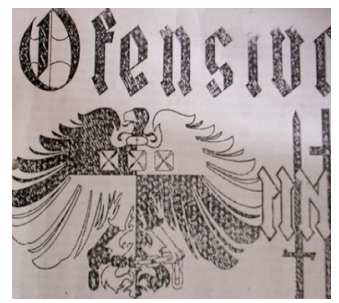

Figura 1 - Ofensiva MNT, 1962, capa (Arquivo Cedinci)

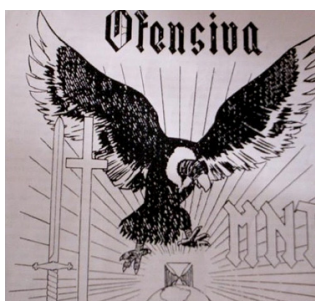

Figura 2 - Ofensiva MNT, 1962, capa (Arquivo Cedinci)

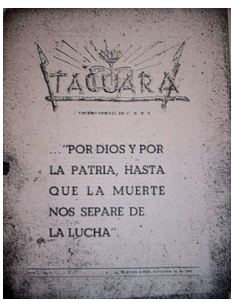

Figura 3 - Tacuara UNES, 1945, сара (Arquivo Cedinci)

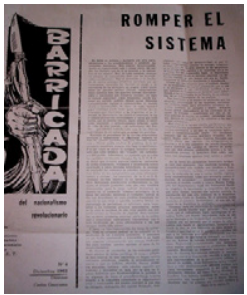

Figura 6 - Barricada MNRT, 1963, n. 4, capa (Arquivo Cedinci)

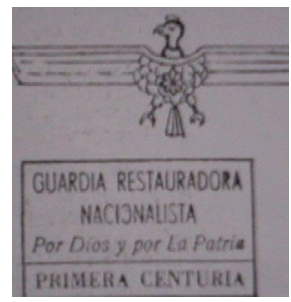

Figura 7-Mazorca, 1966, n.2, contracapa (doação)

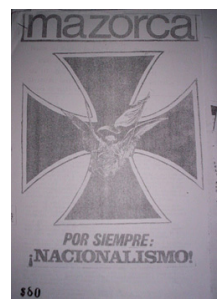

Figura 8 - Mazorca, 1969, n.12, capa (doação)

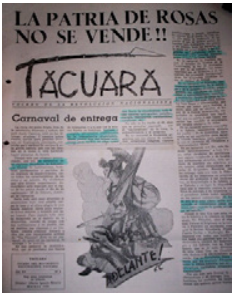

Figura 5 - Tacua ra MNT, 1962(?), n. 8 , capa (Arquivo Cedinci)

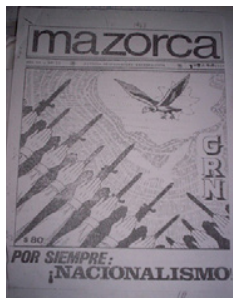

Figura 9 - Mazorca, 1968, n.13, capa (doação)

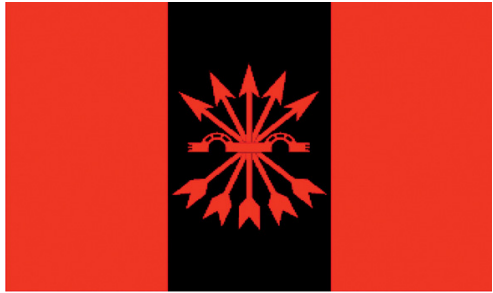

Figura 10 - Emblema da Falange espanhola

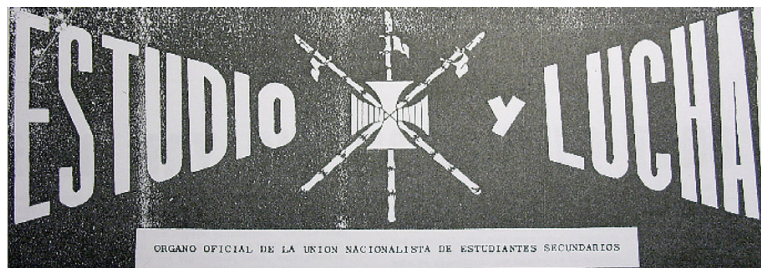

Figura 11 - Logotipo de Estudio y Lucha 


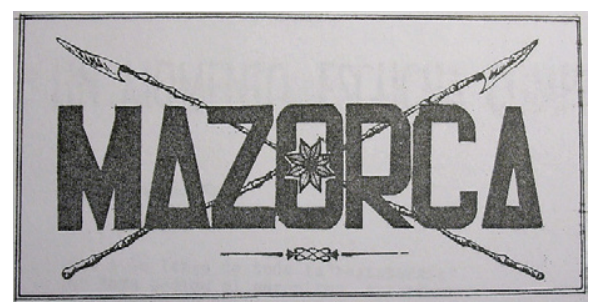

Figura 12 - Mazorca, 1966, capa (doação)

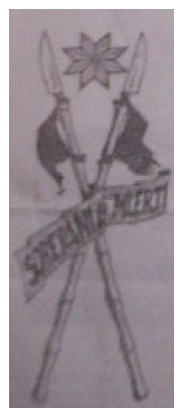

Figura 13 - Barricada, 1964, n.7, capa (Arquivo Cedinci)

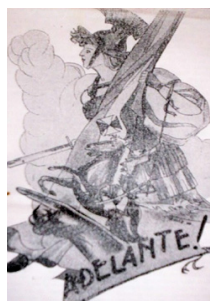

Figura 14 - Detalhe de Tacuara MNT

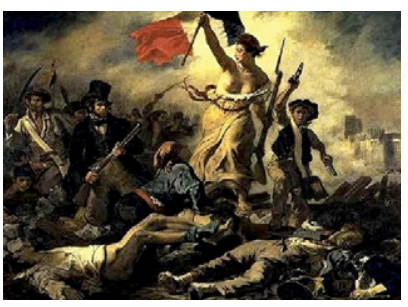

Figura 15 - La Liberté guidant le Peuple, de Eugène Delacroix, 1830

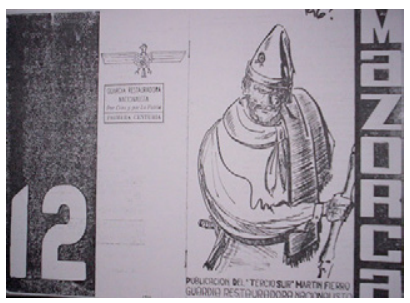

Figura 16 - Mazorca GRN, 1966 , n.12, capa (doação)

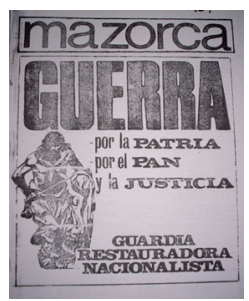

Figura 17 - Mazorca GRN, 1969 (?), n.16, capa (doação)

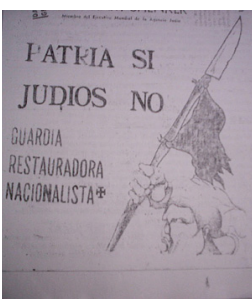

Figura 18-
Mazorca
GRN,
1969 (?),
n.16,
contracapa
(doação)

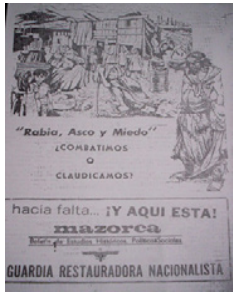

Figura 19 -

Mazorca

GRN, 1969,

n.12,

contracapa

(doação)

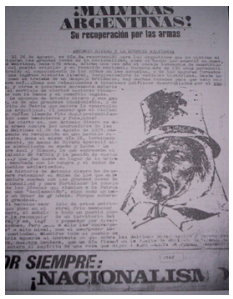

Figura 20 Mazorca GRN, 1968, n.14, contracapa (doação)

\section{Referências bibliográficas}

BARDINI, R. Tacuara: La pólvora y la sangre. México: Editorial Oceano, 2002.

BURKE, P. Visto y no visto: el uso de la imagen como documento histórico. Barcelona: Crítica, 2005.

BURUCÚA, J. E. Historia, arte, cultura: de Aby Warburg a Carlo Ginzburg. Buenos Aires: FCE, 2002.

. Historia y ambivalência: ensayos sobre arte. Buenos Aires: Biblos, 2006. 
CATTARUZA, A.; EUJANIAN, A. El revisionismo: itinerarios de cuatro décadas. In: Políticas de la historia: Argentina 1860-1960. Buenos Aires: Alianza, 2003a.

Héroes patricios y gauchos rebeldes. Tradiciones en pugna. In: Políticas de la historia: Argentina 1860-1960. Buenos Aires: Alianza, 2003b.

DE CERTEAU, M. La belleza de lo muerto: Nisard. In: La cultura en plural. Buenos Aires: Nueva Visión, 1999.

FRANCASTEL, P. La realidad figurativa: elementos estructurales de sociología del arte. Buenos Aires: Emecé Editores, 1970.

GARCÍA CANCLINI, N. ¿Reconstruir lo popular? Exposição feita no Seminario Cultura Popular: un balance interdisciplinario, organizado por el Instituto Nacional de Antropología, Buenos Aires, 1988.

GENÉ, M. M. Un mundo feliz: imágenes de los trabajadores en el primer peronismo 1946-1955. Buenos Aires: FCE-Universidad San Andrés, 2005.

GINZBURG, C. Mitos, emblemas, indicios. Barcelona: Gedisa, 1989.

. Tu País te necesita: un estudio de caso sobre iconografía política. In: Prohistoria, año 7, n. 7, p.11-36, 2003.

GLÜCK, M. Tradición xenófoba y violencia política: Tacuara en Santa Fe a principios de la década del 60. In: Jornadas Historia, etnicidad y literatura latinoamericana: la experiencia del judaísmo contemporáneo. Mendoza: Fundación Auge; Universidad Hebrea de Jerusalén, 2000.

GOMBRICH, E. H. Imágenes simbólicas. Madrid: Alianza, 1983.

La imagen visual: su lugar en la comunicación. In: Gombrich Esencial. Madrid: Debate, 1997.

GUTMAN, D. Tacuara: historia de la primera guerrilla urbana argentina. Buenos Aires: Ediciones B, 2003.

HALPERIN DONGHI. El revisionismo histórico argentino como visión decadentista de la historia nacional. Avellaneda, Siglo 21, 2005.

MARTY, K. L. Neo-fascist irrationality or fantastic history? Tacuara, the Andinia Plan and Adolf Eichmann in Argentina. Michigan: UMI, 1996.

ORLANDINI, J. E. Tacuara... hasta que la muerte nos separe de la lucha: historia del Movimiento Nacionalista Tacuara 1957-1972. Buenos Aires: Centro Editor Argentino, 2008.

PEREZ EDÍA, V, (2003) Hora Cero (las revistas de Oesterheld). Disponível em: <http://www.tebeosfera.com/1/Obra/Tebeo/Frontera/ HoraCero.htm>.

SAXL, F. La vida de las imágenes. Madrid: Alianza, 1989.

VERÓN, E. La semiosis social: fragmentos de una teoría de la discursividad. Barcelona: Gedisa, 1996.

WARBURG, A. El renacimiento del paganismo: aportaciones a la historia cultural del Renacimiento europeo. Madrid: Alianza, 2005. 


\section{5 \\ IMAGINÁRIOS CONTRACULTURAIS \\ NA SEGUNDA METADE \\ DO SÉCULO XX NO MÉXICO: \\ O SURGIMENTO DO MOVIMENTO \\ DO CINEMA EM SUPER 8}

Álvaro Vázquez Mantecón ${ }^{1}$

O propósito deste texto é expor as circunstâncias em que surgiu o movimento do cinema em Super 8 no México no ano de 1970. Nessa época, o país vivia uma explosão de atividades culturais que enfrentavam uma longa tradição de mecenato governamental. Tratava-se em grande parte do impacto e das consequências da crise derivada da repressão ao movimento estudantil de 1968. Nesse sentido, entender o movimento "superochero" permite atender à conformação de uma noção de contracultura, com suas peculiaridades latino-americanas e muito concretamente mexicanas. ${ }^{2}$

Naqueles anos, o conceito de contracultura foi intensamente debatido. Em um artigo editorial que celebrava o número seiscentos do suplemento La cultura en México da revista Siempre!, Carlos Monsiváis fez um balanço da problemática e das perspectivas do

1 Doutor em História da Arte e professor da Universidade Autônoma Metropolitana em Azcapotzalco (México). É curador do Memorial de 1968, situado no Centro Cultural Tlatelolco da Unam. É autor de Emilio "Índio" Fernandez: mexicano mítico. México: Clío, 2000 e Dolores Del Rio. Princesa de México. México: Clío, 1999.

2 Acompanho Marwik (1998, p.11) e entendo a contracultura como um conjunto de atitudes e formas de expressão elaboradas na marginalidade de uma cultura dominante e não como um conjunto coerente e sistemático de ideias. 
panorama cultural mexicano em torno de 1973. Partia do pressuposto de que 1968 havia destruído o conceito de cultura oficial, "concebida - segundo Monsiváis (1973) - como um elemento decorativo ou festivo da classe no poder, carne de efemérides, dedicada a recriar sequências supremas da Humanidade, autofestejante, solene e antissexual". Na opinião do escritor, depois dessa derrubada deveria surgir uma contracultura que interpelaria a cultura dominante. ${ }^{3}$ Naquela época, muitos estavam convencidos de que o Super 8 cumpria satisfatoriamente essa função renovadora.

No início da década de 1970, o Centro de Arte Las Musas publicou em um edital a convocatória para o Primeiro Concurso Nacional de Cinema Independente em $8 \mathrm{~mm}$. Las Musas era uma organização formada por um grupo de artistas e promotores culturais. Dentre eles destacava-se Víctor Fosado, que na época se dedicava ativamente à música, à ourivesaria e à representação (nesse mesmo ano, chegou a interpretar um papel em El topo, filme de Alejandro Jodorowsky); os cineastas Óscar Menéndez e Rubén Gámez; o músico e produtor de rádio Armando Zayas; o escritor Juan de la Cabada e o poeta Leopoldo Ayala. Tratava-se de um grupo diversificado que em boa medida refletia a intensidade criativa que o ambiente cultural mexicano havia experimentado ao longo dos anos 1970. Extraíram seu nome do café em que se encontravam no centro da Cidade do México, que reunia todas as características dos cafés existencialistas contra os quais o governo do Distrito Federal na-

3 Embora Monsiváis (1973) advertisse, em uma crítica clara à Onda, que "uma contracultura no México não pode assumir formas idênticas àquelas utilizadas nos Estados Unidos e na Inglaterra nem deve se dar o luxo do irracionalismo, do exotismo ou da 'expansão da consciência' nos fins de semana”. Para ele, as tarefas da contracultura seriam múltiplas: “...encontrar e estabelecer a tradição radical que lhe interessa (onde figurem - digamos assim - o mesmo Ignacio Ramírez e William Burroughs, Ricardo Flores Magón e Marcel Duchamp); examinar os pressupostos da moral sexual vigente e do sexismo dominante; situar e combater os efeitos e os alcances da penetração imperialista; internacionalizar os feitos e as conquistas da cultura nacional; definir e ganhar o espaço crítico em que poderá se desenvolver; democratizar de modo rigoroso o sentido de sua atividade crítica". 
quela época havia empreendido uma guerra de morte. ${ }^{4}$ Ayala Blanco (1986, p.347) o definia como "um café mortiço e decorado em estilo camp sinistro, com um ambiente de música 'neuroatonal' [referindo-se aos concertos de música contemporânea que ali realizava Juan José Gurrola] [...] lamentando espiritualmente não ter sido edificado sob a ponte de San Francisco". Uma crônica de María del Carmen Martínez (1999, p.12) descrevia o local da seguinte maneira:

Uma luz tênue, avermelhada e amarelada irradiada por umas luminárias estilo Art Noveau de 1900 inunda o ambiente, que em contraste com o negro e os cremes de suas paredes, dá um toque de maior fantasia ao recinto, que é complementado por móveis e decoração do mesmo estilo e da mesma época. De um canto a figurinha de um dragão observa perscrutadoramente os movimentos dos assistentes. Um aparelho telefônico de 1910 parece guardar egoisticamente as conversas mantidas nessa época; tudo isto, acrescentado da presença das nove musas pintadas em telas por grandes nomes da pintura, entre os quais Luisa Durón, Nieto, García Ponce, Góngora, Salvador Elizondo, Pilar Pellicer, Nacho López, Corzas, Víctor Fosado, Isaac e outras grandes personalidades.

Os integrantes de Las Musas haviam se destacado como criadores independentes e resistiam a colocar suas obras no marco de uma cultura estatal que na época parecia ser onipresente, de maneira que não era estranho que lançassem um edital para um concurso de cinema que buscasse promover filmes que saíssem dos circuitos convencionais. Nessa época, a palavra "independente" aplicada à criação artística tinha um valor importante. Em 1968 havia surgido o Salón Independiente, como resultado da resistência de um grupo de artistas plásticos contra o mecenato e a condução da criação cultural por parte do Estado. ${ }^{5}$

4 Sobre os cafés existencialistas, ver Agustín (1996, p.40) e Zolov (2002, p12126).

5 Ver Germenos (2007, p.40-7). 
Algo semelhante ocorria no âmbito cinematográfico. Em 1969 havia se constituído o grupo Cine Independiente de México, formado por Arturo Ripstein, Felipe Cazals, Pedro E. Miret, Rafael Castanedo e Tomás Pérez Turrent, que procurava romper com as condições habitualmente impostas pelos produtores aos roteiristas e diretores, e poder assim consolidar um cinema de autor. ${ }^{6}$ Mas não se tratava apenas de uma busca de independência no interesse da pureza da arte. Também era verdade que o movimento estudantil de 1968 havia causado um profundo impacto na relação entre os artistas e o governo. Cada vez mais frequentemente apareciam grupos como o Las Musas, que decidiam repercutir na criação artística a partir de uma posição marginal.

Diferentemente de outros países, onde havia existido uma tradição importante de cinema amador, ${ }^{7}$ o México havia tido poucos concursos de cinema não profissional. Um deles foi organizado nos anos 1970 pela Pecime, mas teve pouco impacto, ${ }^{8}$ apesar de ter distinguido alguns realizadores de cinema amador do interior do país, como Sergio Tinoco Solar, ${ }^{9}$ ou algum documentário de antropólogos metidos a cineastas, como foi o caso de Arturo Warman e Guillermo Bonfil Batalla, ${ }^{10}$ de maneira que o edital de Las Musas pretendia preencher um vazio no meio cultural do momento.

O centro de arte independente "LAS MUSAS", que há tempos desenvolve uma série de atividades do mais alto nível artístico,

6 Sobre o cinema independente, ver Rieira (1998, p.256-8).

7 Ver: Torella (1965).

8 Blanco (1986, p.346) se referia às distinções do Pecime ao cinema amador como "merecidos prêmios ao esforço, à ociosidade e à falta de autocrítica".

9 Ver Lerner (2003, p.203-7). Tinoco Solar recebeu o prêmio do Pecime em 1967 por seu filme Que Dios los perdone. Disponível em: <http://www.todossomosorizaba.com.mx/sitio2008/archivomunicipal/sitio/0000009b6f0e315 02/0000009b6f0ecfa0b/index.html>. Acesso em: $31 \mathrm{dez} .2008$.

10 Warman e Bonfil haviam ganho un concurso organizado pelo Pecime com um documentário intitulado Él es Dios. Ver Cárdena (s. d.) ¿Underground habemus?, parte da coluna Miscelánea Cultural. Recorte hemerográfico no arquivo de Sergio García. 
como exposições de artes visuais, recitais de poesia, conferências de literatura, assim como concertos de música clássica e moderna, plenamente consciente da grande importância do cinema como arte e linguagem de comunicação, se propõe por meio deste edital convidar todos aqueles que desejem se expressar através da linguagem do cinema para o I CONCURSO NACIONAL DE CINE INDEPENDIENTE. Com os trabalhos dos participantes se pretende fazer uma confrontação real dos cineastas que até este momento não tiveram a oportunidade de apresentá-los para que o público possa valorizar seu esforço, e temos a certeza absoluta de que neste concurso poderá ser valorizada a grande capacidade criativa e técnica de realizadores, fotógrafos, roteiristas, atores, músicos etc. Sem dúvida alguma, neste concurso vislumbraremos o novo panoroma que seguramente algum dia porá um ponto final ao cinema mexicano de má qualidade a que estamos expostos. ${ }^{11}$

Os organizadores pretendiam convocar os cineastas amadores do momento, ao contrário dos Concursos de Cinema Experimental de 1965 e 1967, que pretendiam romper com a obstinação do meio cinematográfico profissional que, com medidas de controle sindical, impediam a entrada de novos diretores e técnicos na indústria. Apostavam claramente em cineastas que não tinham experiência prévia, e por isso especificavam que as fitas deviam durar de dez a 15 minutos e ser filmadas em $8 \mathrm{~mm}$ ou Super $8 \mathrm{~mm}$, ou seja, em formato caseiro. Uma aposta curiosa, visto que no país não existia no momento uma tradição significativa de amadorismo cinematográfico. Além disso, o edital especificava um tema central a ser tratado:

O tema do concurso é "Nosso País". Considerando que este tema engloba todas as possibilidades para construir uma história que possa ser traduzida para a linguagem do cinema, e que pode ser enfocada como um documentário ou uma ficção, não acreditamos ser necessário citar as diversas possibilidades, pois basta perceber o

11 Edital de convocação para o I Concurso Nacional de Cine Independiente (8 $\mathrm{mm}$ ). Arquivo de Sergio García. 
que acontece no país para que cada participante aborde o tema do ponto de vista em que melhor possa desenvolvê-lo. ${ }^{12}$

Neste ponto do edital percebia-se a influência de Rubén Gámez e Óscar Menéndez. Gámez havia sido, em 1965, o vencedor do Primeiro Concurso de Cinema Experimental, com La fórmula secreta (1964), mantinha até esse momento uma carreira cinematográfica à margem da indústria e realizou em seu filme uma exposição eloquente e simbólica - certamente o único filme formalmente experimental apresentado naquela ocasião - contra a colonização cultural que as empresas transnacionais realizavam no México. Por sua vez, Óscar Menéndez, coordenador do concurso, havia realizado vários trabalhos totalmente independentes voltados para a política. Esse foi o caso de filmes como Todos somos hermanos (1965), que tratava da repressão aos movimentos dos professores e dos ferroviários no final da década de 1950 e início de 1960, assim como do assassinato de Rubén Jaramillo.

Durante o movimento estudantil de 1968, Menéndez havia feito dois filmes, Únete pueblo (1968) e Dos de octubre, aquí México (1970), que, junto com os Comunicados del C.N.H. (1968) (realizados sem assinatura por Paul Leduc e Rafael Castanedo), foram os primeiros materiais filmados de difusão do ponto de vista estudantil diante da repressão. Além do trabalho anterior no cinema político, Menéndez conhecia bem as possibilidades do pequeno formato para filmar cenas subversivas: naquela época, havia introduzido uma câmera Super 8 na penitenciária de Lecumberri para que os presos políticos fizessem tomadas das condições em que se encontravam presos. ${ }^{13}$

12 Idem.

13 Menéndez conta que durante os cursos de capacitação para filmar as tomadas necessárias com os estudantes presos teve várias discussões com José Revueltas, que insistia em que a filmagem teria de ser feita com uma câmera de 35 mm, refletores "e todo o aparato cinematográfico". "Não, Pepe, não podemos fazer isso" - contestou Menéndez. Porque ele estava acostumado com o cinema sério. "Vamos colocar uma pequena câmera aí e ver o que podemos fazer." Entrevista com Óscar Menéndez realizada por Álvaro Vázquez Mantecón para o Memorial del 68, Centro Cultural Universitario Tlatelolco, Unam, $1^{\circ}$ de agosto de 2006. 
Apesar de no edital de Las Musas haver um convite velado para se tratar de temas que tivessem a ver com a atualidade nacional, abrigava-se de algum problema possível ao esclarecer que "Os realizadores (diretores) serão os únicos responsáveis pelos temas tratados em seus filmes, ficando os organizadores do concurso eximidos de toda e qualquer responsabilidade" ${ }^{14}$

Por último, o cartaz-edital estabelecia que seriam outorgados como prêmios cinco diplomas "Luis Buñuel", assinados pelo cineasta espanhol, de primeiro lugar aos cinco melhores filmes. E seriam outorgadas menções honrosas para melhor direção, fotografia, edição, roteiro, ator, atriz e música. ${ }^{15} \mathrm{Na}$ decisão de se premiar os cinco melhores filmes com o primeiro lugar observava-se uma resistência, que o Salão Independente havia explicitado naqueles anos, de repudiar o estabelecimento de prêmios hierárquicos em matéria artística. ${ }^{16} \mathrm{O}$ júri seria integrado por Víctor Fosado, o escritor Juan de la Cabada, os cineastas Sérgio Véjar, Óscar Menéndez e Rubén Gámez, o diretor de teatro Jorge Godoy, o músico Armando Zayas e o poeta Leopoldo Ayala. ${ }^{17}$ Mais tarde seria também integrado o prolífico Juan José Gurrola, diretor de cinema e teatro, além de assíduo concertista de música neuroatonal em Las Musas. ${ }^{18}$

O edital de Las Musas teve uma boa divulgação. Foram inscritos um total de vinte filmes, um número importante, considerando-se a escassa tradição de cinema amador no momento. Nenhum dos participantes do Concurso tinha experiência cinematográfica profissional. Talvez o mais próximo disso tenha sido Gabriel Retes, que provinha de uma família de teatro e havia participado como ator em alguns filmes de cinema industrial (Alfaro, 1999, p.21-2). Entretanto, sua filmagem para o concurso foi realizada de maneira praticamente improvisada.

14 Edital para o I Concurso Nacional de Cine Independiente, Op.Cit.

15 Idem.

16 Ver Germenos (2007).

17 Cartaz do edital para o I Concurso Nacional de Cine Independiente. Op.Cit.

18 "Fala Juan José Gurrola. Películas de 8 milímetros para cineastas inquietos", por Socorro Díaz, El Día, 29 de maio de 1970. 
Numa certa quinta-feira, minha irmã chegou com uma pequena câmera de Super 8, dizendo, "está sendo anunciado um concurso de cinema Luis Buñuel". "Que boa notícia! Por que não fazemos um filminho no fim de semana? Vamos até Ajusco." "Mas como vamos fazer um filme? O que vamos fazer?" Eu gosto muito dos westerns. "Bem, lá há cavalos". Mas não tínhamos dinheiro nem para os cavalos. "Quem sabe conseguimos uns paus de vassoura, bla, bla, bla..." Na sexta-feira surgiu esta ideia. No sábado e no domingo filmamos. Eu tinha um visorzinho, uma moviolinha, e do meu jeito montei e editei o filme na segunda e na terça, e na quartafeira o entregamos para o concurso. ${ }^{19}$

Alguns concorrentes, como Sergio García, tinham alguma experiência anterior com o formato Super 8, embora não tenham realizado formalmente um filme. Assim como outros participantes, García fez para o concurso seu primeiro filme (El fin), ajudado por amigos com os quais havia formado um grupo cultural a que haviam dado o nome de "Liberación" e que refletia em boa medida a inquietação da classe média da capital no fim dos anos 1970:

Realmente comecei em 70, com El fin, porque foi realizado um concurso de cinema independente. Eu tinha minha camerazinha e tínhamos um grupo cultural. 1968 havia acabado de terminar, e formamos um grupo que pretendia transformar o mundo. Nós nos reuníamos todos os domingos para falar de religião, de política, de filosofia, de pintura ... Convidávamos José Agustín, Parménides García Saldaña, Margarita Bauche. E inclusive o guru da Grande Fraternidade Universal, que se chamava Estrada - o guru Estrada. Portanto, os personagens mais diversificados. ${ }^{20}$

19 Entrevista com Gabriel Retes por Álvaro Vázquez Mantecón, 8 de setembro de 2005.

20 Entrevista com Sergio García por Álvaro Vázquez Mantecón, 19 de abril de 2005. 
Naquela época, Sergio García trabalhava em uma agência de publicidade (andava de terno e gravata). Alfredo Gurrola, irmão de Juan José e participante de destaque do concurso, decidiu participar com um grupo de companheiros de trabalho (do grupo de aluguel de automóveis da Volkswagen). O pai de um deles havia lhes emprestado uma câmera e realizaram a edição com uma lupa, porque não tinham visor nem moviola. ${ }^{21}$ Pelo menos dois dos concorrentes (Sergio García e David Celestinos) haviam se inscrito no Centro Universitario de Estudios Cinematográficos (Cuec) da Unam, a única escola de cinema que existia naquela época. Entretanto, sua passagem pela escola foi efêmera e não haviam chegado a realizar exercícios de filmagem em formato profissional. ${ }^{22}$ Os organizadores do concurso haviam conseguido despertar a inquietação de um setor amador da sociedade mexicana.

A imprensa da Cidade do México acompanhou com interesse o concurso, que se realizou durante o mês de maio de 1970. Vários jornais lhe dedicaram notas que se estendiam desde a curiosidade e a imprecisão até a resenha pontual. Uma nota de El Heraldo afirmava que o tema central era

"Nossa Pátria", e que "embora não fosse ser concedido nenhum prêmio em dinheiro, os cinco finalistas teriam a oportunidade de enviar seus filmes para concursos internacionais de cinema novo, como os de Roma e Paris, onde recentemente ocorreram este tipo de eventos". (Serrano, 1973, p.25)

Mas alguns jornalistas, como Emilio Arízaga, de El Día, Arturo Garmendia, de Esto, e o crítico Jorge Ayala Blanco, de Excélsior, acompanharam com muita atenção o concurso e escreveram rese-

21 Entrevista com Alfredo Gurrola por Álvaro Vázquez Mantecón, 5 de abril de 2005.

22 Entrevista com David Celestinos por Álvaro Vázquez Mantecón, 29 de janeiro de 2005 . 
nhas dos filmes que foram premiados pelo júri. Os procedimentos do concurso foram realizados no Club de Periodistas, na rua Filomeno Mata do centro da Cidade do México, no final de maio de 1970. As manchetes da imprensa anunciavam com certa surpresa os filmes projetados: "Continua a Boa Qualidade dos Filmes do Concurso de Cinema Independente" ou "São Cada Vez Melhores os Filmes do Concurso de Cinema de $8 \mathrm{~mm}$ " (El Día), "Concurso Nacional de Cinema! Cinema Underground de $8 \mathrm{~mm}$ e à Mexicana" (Excélsior). ${ }^{23}$

Alguns filmes que participaram do concurso tinham um caráter de documentário convencional de viagem e não foram resenhados positivamente pela imprensa nem selecionados pelo júri. Foi o caso de Baja California Sur, paraíso perdido, de Romeo Hernández, ou de Estampas de México, de Luis Vicens (sobre o qual um crítico escreveu na imprensa que, apesar de ter "uma excelente fotografia", tratava-se de "um bom trabalho, mas nada além disso") (Arízaga, 1970), e de dois filmes de José Arias: El Mercado de la Merced e Quién mató a Cristo 70? (este último sobre a representação da Paixão na Semana Santa em Iztapalapa) (ibidem). Mas na maioria dos trabalhos se percebia inquietação e uma posição crítica que em grande parte era resultado do movimento estudantil de 1968 e de uma estética contracultural que fazia oposição aos valores de um mundo adulto de uma posição declaradamente juvenil. Tanto os críticos como os juízes destacaram filmes que manifestavam uma posição crítica por parte de seus realizadores. A premiação teve lugar na Galería Edvard Munch, de Leopoldo Ayala, onde se fez uma exposição com fotogramas dos filmes premiados. ${ }^{24} \mathrm{O}$ júri outorgou cinco diplomas de primeiro lugar, assinados por Luis Buñuel, aos seguintes filmes:

- El padre ou Why?, de Enrique Escalona e Galo Carretero;

- La grieta, de Luis Cisneros e César Rattoni;

23 Citadas por Sergio García, Op.Cit., p.27-8.

24 "Concurso Nacional de Cine", Excélsior, sexta-feira, 29 de maio de 1970. 
- El fin, de Sergio García;

- Mi casa de altos techos, de David Celestinos;

- El tercer suspiro, de Afredo Gurrola.

Também foram concedidas sete menções honrosas a El último día del señor Cámara, Así es esto de los coches europeos, La lucha, I hate your generation, Amanecer, Jícama e Sur. Carlos Héctor e Karen Roel foram premiados por sua atuação, César Rattoni pela fotografia, Enrique Escalona pela edição, Eduardo e Karen Roel pela música, e David Celestinos obteve um prêmio por roteiro e outro por direção. ${ }^{25}$

$\mathrm{O}$ curioso era a semelhança entre os filmes. Talvez isso tivesse a ver com a direção imposta pelo interesse dos juízes, mas a verdade é que muitos filmes compartilharam os temas tratados, os pontos de vista e as formas de tratamento. Faziam uma crítica aos poderes estabelecidos (Igreja, políticos, Exército, família), denunciavam a indiferença social com relação à miséria, aludiam ao que acontecia no cenário (como o movimento estudantil de maio na França ou a guerra do Vietnã), ou se perguntavam sobre o rumo que a arte devia seguir nesse momento. Ayala Blanco (p.353) destacou as características em comum que, do seu ponto de vista, boa parte dos filmes compartilhavam.

Esta sequela de barbudos românticos, repressões de rua, agressões aos símbolos do poder e solidariedade reverente com o folclore da rebeldia juvenil norte-americana; esta busca insistente de aproveitar a liberdade temática do concurso para dar forma a uma visão impugnadora da realidade social mexicana em um contexto amplo; estas informações estritamente pessoais que desembocam no desafogo autobiográfico; esta repetição de referências e símbolos externos, chegam a mesclar na memória numerosas cenas dos filmes. É como se todos os jovens participantes tivessem querido 
fazer o mesmo filme. Como se a ninguém importasse a produção "poética" ou "novelesca", e só fosse admissível pulverizar o espaço fílmico para dar lugar a um espírito combativo, nascido há menos de dois anos.

Os filmes do concurso manifestavam uma rebeldia herdeira de 1968. Em muitos deles estava representada a Unidad Habitacional de Tlatelolco (que no momento havia perdido seu caráter emblemático da modernidade mexicana para se converter em um símbolo da repressão), ou então eram feitas alusões diretas ao massacre. Esse era o caso de Jícama, de Salvador Díaz Zubieta, de El fin, de Sergio García, e de La grieta, de Luis Cisneros e César Rattoni. Em Mi casa de altos techos, de David Celestinos, havia uma menção a 1968 como ponto de partida de uma alternativa artística. Ou em El tercer suspiro, de Alfredo Gurrola, em que 1968 marcava um contexto que dava sentido à história.

Não haviam se passado nem dois anos desde 68 [...] E todos de alguma forma tínhamos uma posição diante disso. E quando nos foi dada a camerazinha, a possibilidade não só de fazer o filme, mas de que ele tivesse uma exibição posterior, foi o que mais nos motivou. Porque não duvido de que se não tivesse havido esse concurso, talvez alguém tivesse feito filmes contestatórios, ou em resposta ao que ocorria, mas isso não teria tido repercussão. $\mathrm{O}$ fato de se promover um concurso cujo tema era "Nosso México" (sic) fez com que todos, ou cerca de 85 ou 90 por cento dos filmes, de alguma forma tangencial ou direta tocassem esse ponto. Houve outros que eram uma paisagem de um burrinho caminhando diante dos vulcões e... sabe como é, não? Mas a maioria tinha um toque de expressão contida. ${ }^{26}$

Alfredo Gurrola havia realizado seu filme sem uma formação prévia, com um equipamento emprestado de $8 \mathrm{~mm}$ e a colaboração

26 Entrevista com Alfredo Gurrola, Op.Cit. 
de um grupo de companheiros de trabalho. Todos tinham aproximadamente vinte anos. A ideia central do filme havia surgido do fato de um deles ter sonhado que tinha balas no cabelo. Daí o grupo teceu a história de um jovem que caminha pela Alameda e é obrigado a subir em um automóvel onde estão um político, um militar e um capitalista ("as forças vivas", recorda Gurrola) que disparavam contra ele. "Mas cada vez que disparavam, ele tinha uma espécie de sensação de fuga, de fugir do automóvel. Só que sempre, por alguma razão, ele fugia, fugia, fugia e voltava a cair no mesmo automóvel. Não conseguia escapar". ${ }^{27}$ Uma crítica de Arturo Garmendia em Esto fazia uma síntese do filme:

EL TERCER SUSPIRO. Separa-se de um grupo de transeuntes na Alameda um jovem que, ao aceitar o convite que três desconhecidos (identificados com o movimento revolucionário de 1910 mediante uma montagem de fotografias da época) para entrar em um automóvel, durante o passeio pela periferia se vê assaltado por uma série de evocações imaginárias. Primeiro, se vê fugindo do automóvel saltando para uma passagem de pedestres, e ser perseguido através de casas destruídas. Ao regressar ao tempo presente, um dos homens coloca um revólver em sua mão. Depois se vê em um lugar deserto, penosamente mantido de pé por um aparelho ortopédico, enquanto uma maré crescente começa a cobri-lo. Nesse ponto, desce do automóvel em movimento e se coloca no centro da estrada, ameaçando com a arma algo que se aproxima; mas antes que ocorra o disparo evoca um encontro amoroso. Esta ação se repete várias vezes antes de se dissolver nas imagens de um lago que agora o cobriu inteiramente.

A dosificação adequada dos efeitos - câmera lenta na fuga, diversidade de planos e ângulos para demonstrar a inundação proposta, reiteração de movimentos na montagem final de violência e erotismo - mais a correta definição de cada um dos tempos que 
compõem esta metáfora, lhe proporcionam a angústia que descreve uma qualidade poética. ${ }^{28}$

Em um artigo jornalístico em que se fazia um inventário do melhor do cinema mexicano da década de 1970, Garmendia voltou a ocupar-se do filme. Destacava no cinema industrial Los nuestros, de Hermosillo, Los adelantados e Q.R.R., de Alatriste, e inclusive o Tunco Maclovio, de Mariscal - mas coloquei El tercer suspiro em um lugar privilegiado, considerando-o "o melhor dos curtas-metragens em $8 \mathrm{~mm}$, uma discreta experiência em poesia fílmica e talvez o início de uma carreira, em um concurso que talvez seja o início de uma série" (Garmendia, 1970). Por sua vez, Jorge Ayala Blanco (1986, p.351) escreveu uma crítica positiva, na qual destacava que "Gurrola havia captado a coerência de um estado de ânimo dentro das dimensões de uma zona intermediária entre o sonho e a realidade; uma espécie de presente integral, desordenado e impuro".

A sensação persecutória também estava presente em outros filmes, como El fin, de Sergio García. Com seu grupo de amigos, todos eles membros de famílias da classe média conservadora do bairro de Tlalpan, ao sul da Cidade do México, ${ }^{29}$ ele havia filmado uma história sobre a perseguição sofrida pela juventude por parte do mundo dos adultos. A posição alternativa do grupo era explicitada desde as primeiras tomadas, onde os créditos apareciam escritos nas paredes de uma casa em ruínas, omitindo os sobrenomes e apresentando apenas os nomes de batismo daqueles que participaram: "El fin/Por ordem de aparecimento/Octavio, Lisy, Ricardo/Marilú, Jorge, Felipe, Rafa, Lalo/Assistente de direção, Ricardo/Roteiro, fotografía, edição, adaptação musical, Sergio/Produção, Grupo Liberación/ Direção, Sergio". No fundo, soava a canção "The end”, do grupo The Doors. Em seguida aparecia um homem jovem, de terno e bigodinho, aflito atrás de umas grades que formam o mapa do México.

28 Citado por Sergio García, em Hacia un $4^{\circ}$. cine, p.32.

29 Entrevista com Felipe Tirado por Álvaro Vázquez Mantecón, 14 de outubro de 2008 . 


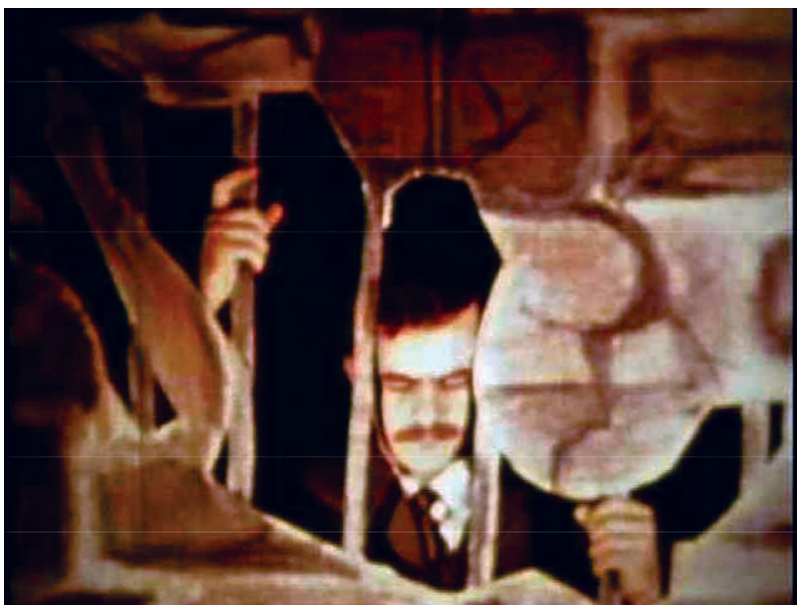

El fin (1970), de Sergio García.

O que acontece é que... veja, é difícil de entender agora, mas realmente até 68 a sociedade mexicana era opressiva, muito opressiva sobre os jovens. E muito repressiva também. Opressiva e repressiva. Éramos presos de... de que seria? Presos de expressão; os jovens não podiam se expressar, não podiam usar cabelo comprido nem nada... Eu pertencia a uma juventude totalmente reprimida. Não apenas na escola, mas na minha casa e na sociedade... era obrigado a ir à missa todos os domingos, a respeitar o pai; "não coloque os cotovelos na mesa", "mastigue com a boca fechada", "diga com licença e por favor...". E, naturalmente, sexo, não, não, não! O sexo era proibidíssimo, não era? - A prisão era a sociedade ou a nação? Ambas: a sociedade da nação e a nação enquanto sociedade. ${ }^{30}$

Naquela época, carregada de um nacionalismo oficial e praticamente obrigatório, a imagem e o conceito tinham uma forte carga subversiva. Nesse sentido, Sergio García encontrava-se muito próximo da posição desenvolvida naqueles mesmos anos pelos escritores da Onda, como Parménides García Saldaña e José Agustín, que

30 Entrevista com Sergio García por Álvaro Vázquez Mantecón. 
costumavam zombar do nacionalismo e exploravam de maneira crítica uma cultura associada ao rock que fazia dos jovens mexicanos uma juventude, pela primeira vez na história do país, globalizada. ${ }^{31}$ A esse respeito, Carlos Monsiváis (1977, p.225-262) escreveu que

a Onda é uma utopia "desnacionalizada": o México é o buraco moralista de onde é preciso sair; o México é a contingência (aqui nos atingiu, este é o nosso idioma, nossos pais praticam estes costumes) e a fatalidade (moral, tradições, cultura do alcoolismo, vida que eliminou qualquer percepção insólita).

Em seguida aparece um casal de jovens alternativos. Ele usa barba, veste um colete sem camisa; ela se veste de branco, com um chapeuzinho, e pinta um quadro no cavalete. Estão colocados em um cenário idílico, uma espécie de bosque ou jardim muito denso. Enquanto isso, escuta-se a canção "You can't always get what you want”, dos Rolling Stones. Estão felizes: observam o jorro de uma fonte, internam-se no bosque. Uma série de planos abertos realça seu idílio jipiteca. ${ }^{32}$ Ele toca violão, e ela, flauta. Correm e a câmera os tira de foco até que penetram no bosque. Dissolvência e tilt up em direção à copa das árvores. Fazem uma fogueira e começam a ser perseguidos por um aldeão montado a cavalo (neste momento escuta-se na trilha sonora a música do filme El bueno, el malo y el $f e o$ ), ao qual se unem uma mulher de roupão (uma mãe), um soldado, um cura e um homem de terno, que perseguem o casal. Escutase de novo "The end". Capturam o jovem e o obrigam a tomar uma mamadeira. O sacerdote caminha arrogante e venda os olhos do jovem que toca harmônica na praça da igreja de Chimalistac. $\mathrm{O}$ soldado tira-lhe a harmônica e coloca-lhe um fuzil entre as mãos; o aldeão o enfia em uma adega. O homem de terno o leva até uma loja ("Los 70`s"). O barbudo fuma maconha, mas o homem de terno tira-lhe o cigarro e obriga-o a tomar uma Coca-Cola.

31 Evidentemente, não foi por acaso que Parménides García Saldaña assistiu algumas vezes às reuniões do Grupo Liberación, nem que José Agustín e Sergio García chegaram a colaborar estreitamente em projetos de Super 8.

32 Jipiteca: nome dado ao movimento hippie no México após 1968. (N. da T.) 

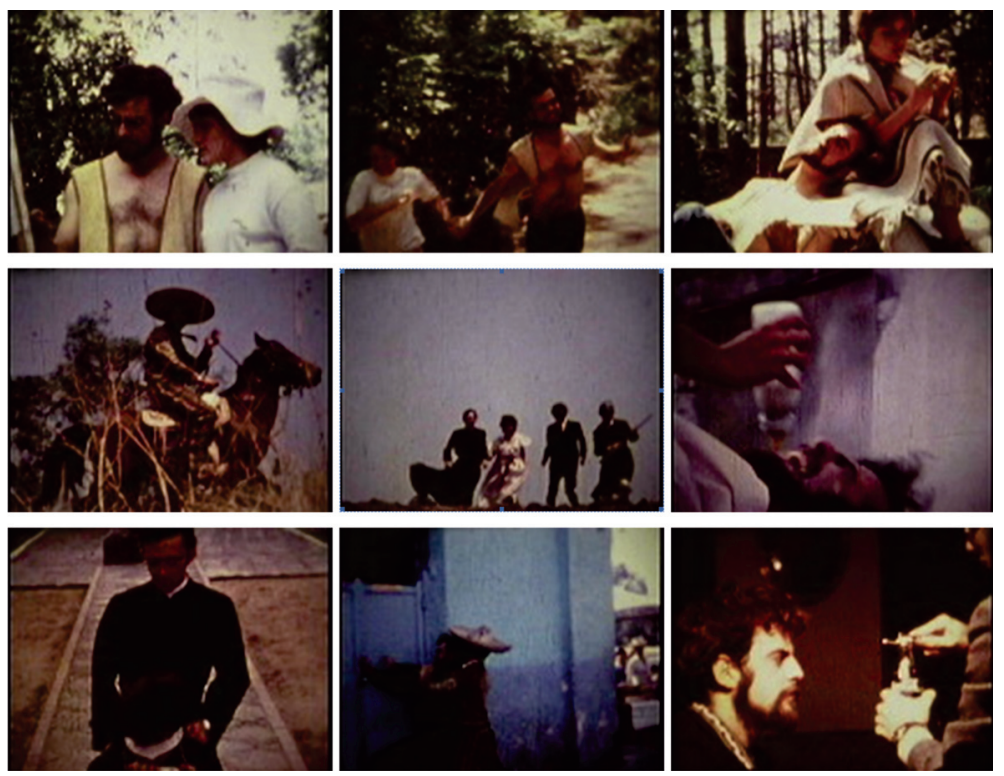

El fin (1970), de Sergio García.

O soldado corre por um corredor de pedra e dá uma coronhada em um jovem (outro distinto daquele perseguido pelo aldeão, a mãe, o cura e o homem de terno), que fica estendido com um jorro de sangue na cabeça. Funde-se com a praça das três culturas de Tlatelolco, mas vista como que através de um magiscópio de Feliciano Béjar. ${ }^{33}$ Mesclam-se imagens variadas sobre uma parte acelerada da música do The Doors, para dar uma sensação de vertigem: um anúncio de Coca-Cola no mundial, o Monumento a la Raza, diversas cenas da cidade, propaganda política de Luis Eche-

33 Durante os anos 1970, o artista Feliciano Béjar fazia magiscópios, peças em que se combinava a ourivesaria com a arte óptica. Eram uma espécie de pé de abajur que sustentava um cristal que produzia uma difração da visão. O efeito já havia sido experimentado no cinema por Gelsen Gas em Anticlímax (1969), em uma sequência filmada na casa de Béjar em Altavista, onde eram mostradas imagens modificadas pelo magiscópio. Sobre os magiscópios e a obra de Béjar, ver Foley (1992). 
verría (então candidato à presidência da República), um anúncio de cerveja, outro de automóveis, o Monumento à Revolução, com uns meninos da rua de baixo, um cartaz que proíbe a volta da esquerda, a bandeira de listras e estrelas da embaixada norte-americana, o Monumento à Independência, o anúncio de Bancomer. Finalmente, termina a vertigem da montagem e o jovem, agora de terno e bigode (reconhecemos o personagem inicial na prisão com forma de mapa) conduz seu automóvel, escuta uma canção de Armando Manzanero ("Adoro") e percorre a cidade, passando pela praça do Metrô Insurgentes.
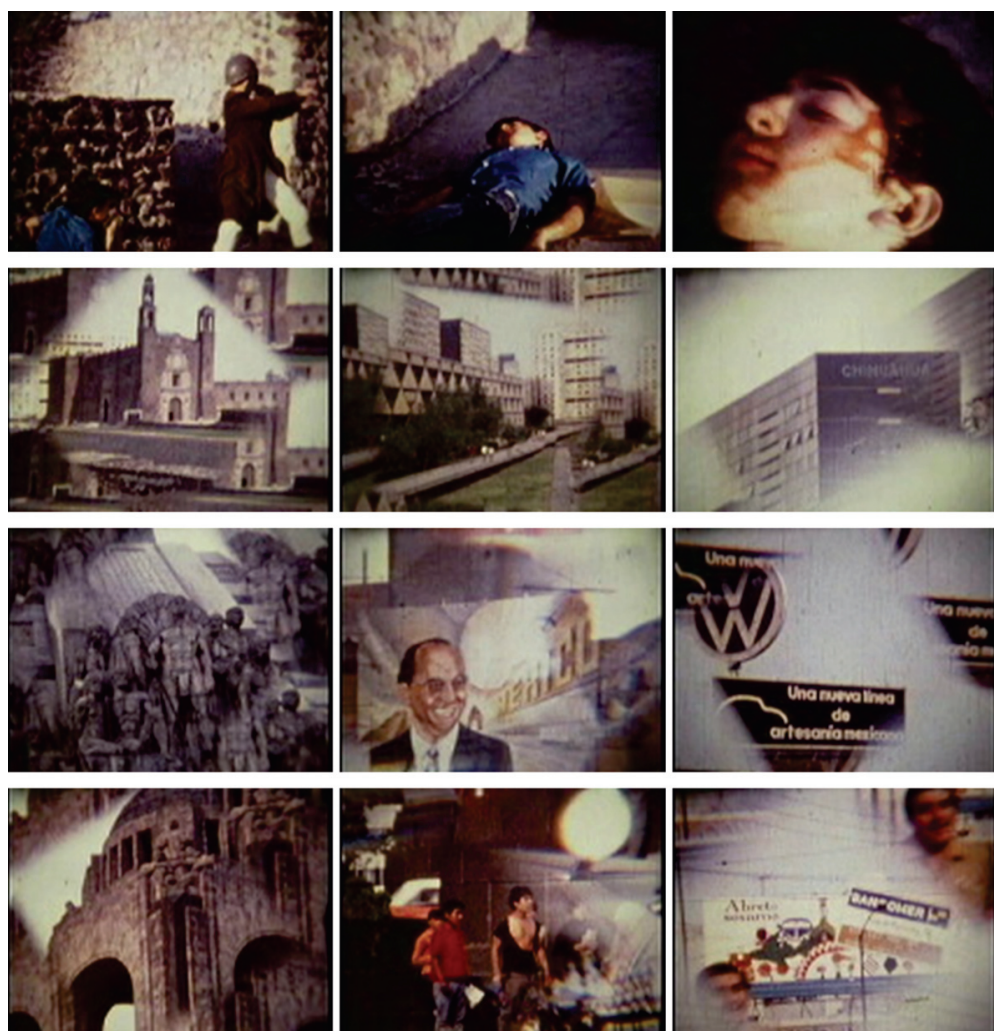

El fin (1970), de Sergio García. 
O filme de Sergio García apresentava uma visão nítida do que os jovens próximos da contracultura pensavam no momento. A trilha sonora - é preciso lembrar que na época era muito difícil colocar diálogos em um filme Super 8, e por isso o papel da trilha sonora é importante, pois constitui um elemento de articulação fundamental nas sequências - baseia-se em canções de rock (The Doors, The Rolling Stones), e a única peça mexicana ("Adoro", de Manzanero) é ironicamente apresentada como símbolo da alienação do personagem.

Apesar de se tratar do primeiro trabalho formal realizado por García, percebia-se nele uma série de referências a uma cultura cinematográfica atualizada que ia desde a nova onda francesa (Acossado, de Jean-Luc Godard) até o western spaguetti (a música de Três homens em conflito, de Sergio Leone, ou a referência a Era uma vez no oeste, na harmônica que o jovem toca enquanto o sacerdote venda-lhe os olhos). ${ }^{34}$ Suas sequências representavam - talvez de maneira ingênua - as ideias fundamentais da contracultura juvenil: a associação do casal juvenil com a natureza e a arte como únicas possibilidades para a expansão do espírito, a luta dos poderes fácticos (a família, o Exército, a religião e o capitalismo), a resistência aos símbolos do Estado, como os monumentos oficiais, ou a progaganda eleitoral. É uma mostra também de como a contracultura mexicana do momento havia assimilado como um agravo próprio à repressão do movimento estudantil de 1968, apesar das constantes críticas que na época os jovens militantes de esquerda faziam à despolitização contracultural.

El fin chamou a atenção daqueles que o viram no concurso. Sobretudo, foram feitos comentários sobre o uso da música no curtametragem. Emilio Arízaga (El Día) escreveu que ele tinha "uma linguagem ágil, brilhante (salvo uma primeira parte demasiado

34 No filme Era uma vez no oeste (1968), de Sergio Leone, o personagem interpretado por Charles Bronson recorda que quando criança foi obrigado por um pistoleiro a tocar harmônica enguanto carregava seu irmão nos ombros. Se ele se mexesse, o irmão morreria enforcado. 
idílica e estereotipada). Seu diretor, sem dúvida, tem recursos, e as partes fársicas do filme são deliciosas, com um excelente apoio na música". ${ }^{35}$ Ayala Blanco (1986, p.350) destacou que o filme "sincroniza imagens muito estudadas, irônicas ou psicodélicas, com a música folclórica norte-americana. Os episódios se justapõem com agilidade, ajudados pelos comentários musicais". Menos complacente foi a resenha de Arturo Garmendia, de Esto, a quem pareceu que "o traçado radical da situação e o emprego irônico da música não encontram apoio em uma realização convincente: giros aloucados, enquadramentos defeituosos, insertos insignificantes, conformam seu holocausto de bolso e sua zombaria atabalhoada dos sobreviventes mediatizados". ${ }^{36}$ Contudo, García seguiria o modelo de montagem em contraste com a música em muitos de seus trabalhos seguintes. Outra linha de trabalho que Sergio García preservaria era a crítica ao discurso dos meios de comunicação de massa, expressado por meio do bombardeio visual da propaganda comercial ou política.

Em um sentido muito próximo encontrava-se Jícama, outro filme que participou do concurso. Este curta-metragem, realizado por Sergio Díaz Zubieta e O. Santos, não ficou entre os cinco primeiros lugares, mas obteve uma menção honrosa. O filme realizava uma montagem lúdica ao justapor as mensagens políticas oficiais escritas nos muros da cidade com imagens ou textos que as ironizavam ou alteravam seu sentido. O título origina-se de um jogo de palavras com o fraseado das sílabas "me-xi-co/jí-ca-ma", que costumava ser usado pejorativamente na época nas partidas de futebol da seleção nacional. De maneira parecida com El fin, o filme foi editado ao ritmo de uma canção de rock , "I need a man to love", de Janis Joplin, o que lhe dava um tom claramente contracultural, ao mesmo tempo que estabelecia uma brincadeira com a imagem do candidato presidencial como um possível galã. A aposta de Díaz Zubieta e

35 Emilio Arízaga, "Continua a boa qualidade dos filmes no concurso de cinema independente", Op.Cit.

36 Citado por Sergio García, Hacia un $4^{\circ}$. cine..., p.33. 
Santos era expor o absurdo da retórica oficial do regime, presente em cabeçalhos do jornal que naquela época apresentavam nos títulos frases extraídas dos discursos do presidente da república ou de algum outro político de destaque, e confundiam doentiamente uma notícia com a retórica.
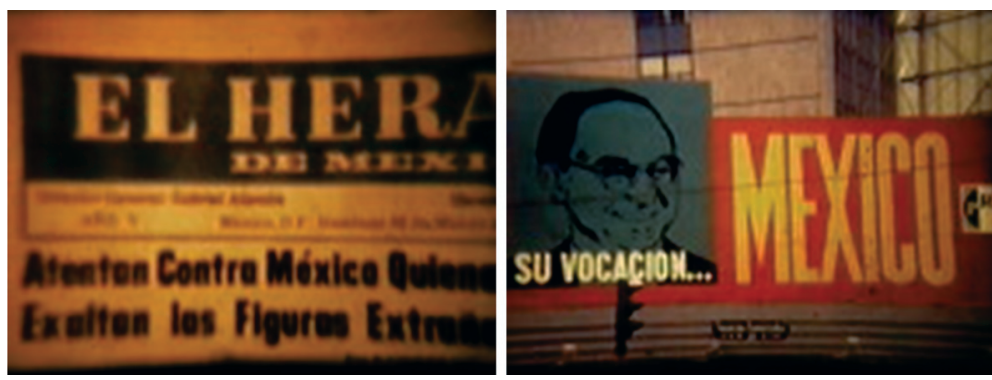

Jícama (1970), de Sergio Díaz Zubieta e O. Santos.

Em algumas ocasiões, a simples palavra de ordem de alguns letreiros não requeria montagem para mostrar o absurdo em que o discurso oficial costumava cair: "Nosso verdadeiro patrimônio é o mexicano" ou "Nós patriotas votamos assim", por exemplo. Mas, na maioria dos casos, a força da mensagem encontrava-se na justaposição de imagens. Muitas vezes, a mesma composição do quadro já implica uma oposição consciente dos sentidos que não necessita da montagem, como se pode ver na composição conjunta de um símbolo do Partido Popular Socialista e de um anúncio de roupa, ou no quadro em que se mostra um lema oficial pintado em um muro e se observa uma casa miserável na parte superior. Ou na maneira em que os realizadores consignaram muros utilizados como progaganda política que foram adulteradas pelos opositores, como no caso do logotipo do Partido Popular Socialista, considerado na época como um "satélite" do partido oficial, ao qual se sobrepõe a legenda "ladrões, vendidos", ou o do PRI sobre o qual alguém pintou uma suástica. 

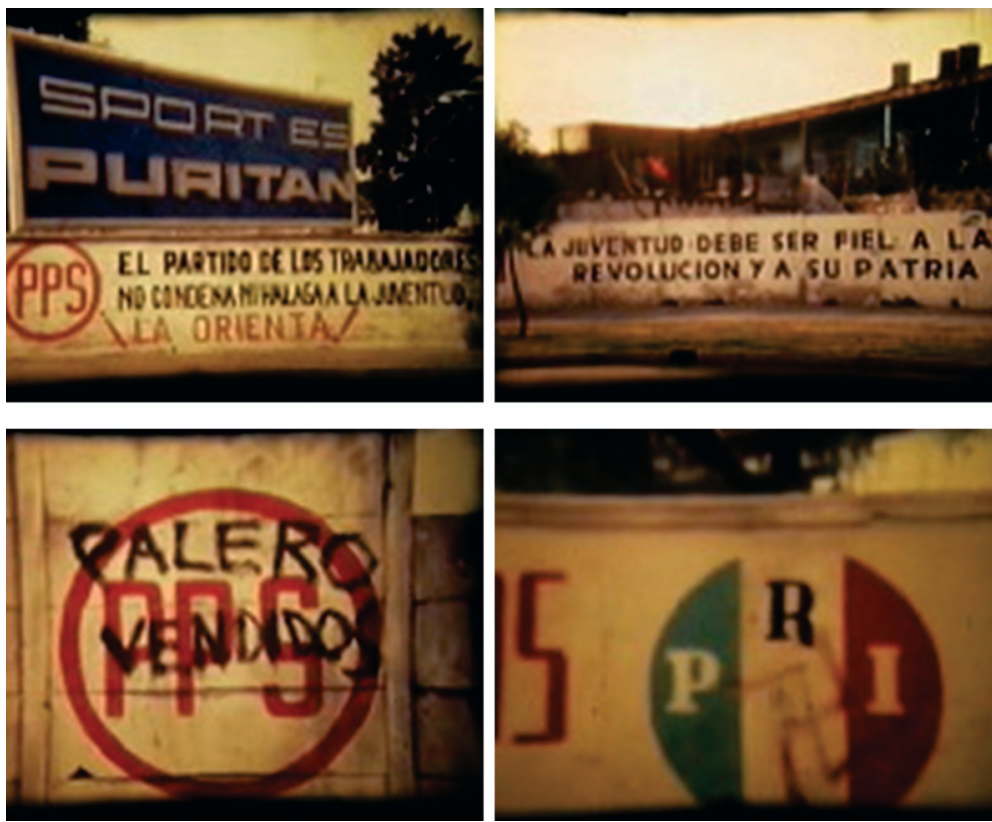

Jícama (1970), de Sergio Díaz Zubieta e O. Santos.

Entretanto, a força do filme encontrava-se na edição. A fita inicia-se com uma tomada do Monumento a la Revolución, indicando ao espectador que ele vai presenciar uma crítica ao regime. Imediatamente depois apresenta-se um plano rápido sobre uma propaganda da campanha de Luis Echeverría, que anuncia: "A falsidade é própria da ditadura”. A câmera concentra-se no logotipo do PRI e faz um corte na palavra "ditadura" que combina de maneira alternada com uns postes de eletricidade para finalizar em uma imagem do Mickey Mouse colocando o dedo na frente da palavra "ideia", associando o PRI com a ditadura, como pode ser observado no seguinte fotograma que indica o corte de uma imagem com a seguinte: 


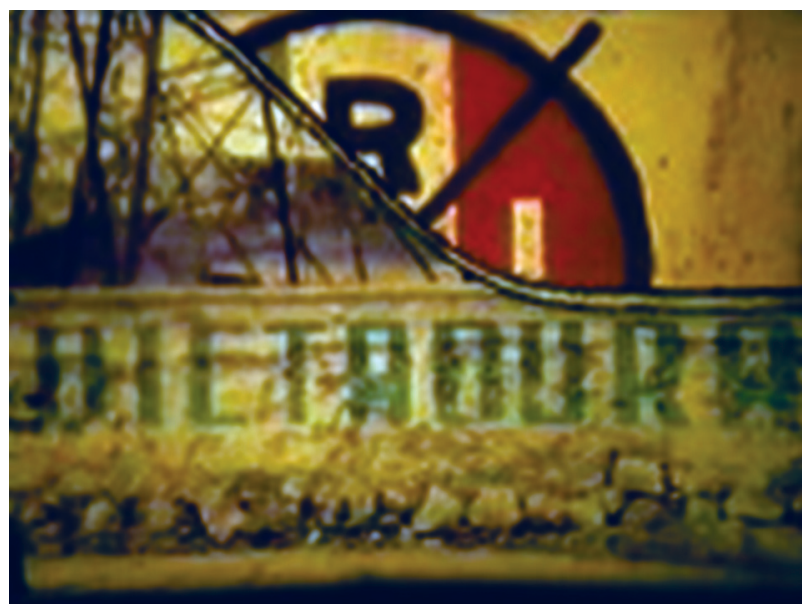

Jícama (1970), de Sergio Díaz Zubieta e O. Santos.

A montagem mostrava uma grande agilidade. À guisa de exemplo, descrevo a seguir uma das sequências. Aparece um cartaz estilo pop de Luis Echeverría que diz: "México: sua vocação". Plano rápido nas letras, provavelmente extraídas de um comercial publicitário: "tem ânsia de poder ou de serviço". "Você já o conhece. Vote no PRI." Foto de lontras nadando. Montagem entre o nome "Luis Echeverría" e marquesina (toldo) com o título "Quando você precisar de mim". Foto de uma mulher seminua. "Abre-te sésamo", em um cartaz publicitário. "A grande mudança." Caricatura em que aparece um grupo de pessoas assustadas. "Vamos para uma nova etapa da história." "A dignidade, a independência, a justiça, a paz." Foto de uma negra obesa rindo. "Liberdade para os presos políticos" (esta é uma das poucas mensagens políticas não oficiais). "Juventude: seja inflexivelmente revolucionária." Ou, em outras ocasiões, a edição para uma paródia entre a escolha de partidos políticos ou da marca de um refresco, precedida da frase "Por uma democracia econômica" (sic). 

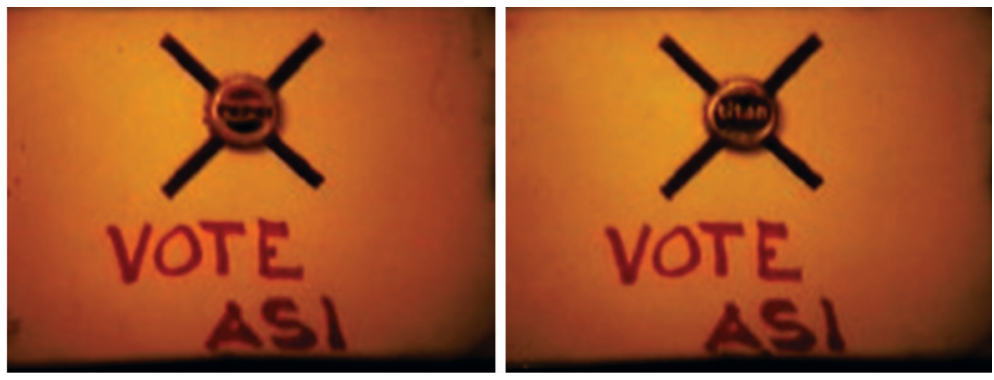

Jícama (1970), de Sergio Díaz Zubieta e O. Santos.

É interessante que várias vezes os autores inserem imagens eróticas como uma maneira de ridicularizar o discurso político. Em uma parte do filme há uma tomada que mostra a união de dois letreiros na mesma imagem: "Recebem-se pensões" e o lema presidencial da campanha de Luis Echeverría, "Para cima e para frente", ao que segue uma imagem em close up de um par de seios, tirada de uma revista pornô. Hoje em dia é menos frequente que se faça oposição ao discurso político hegemônico com piadas sexuais, mas nesse momento o filme estabelece uma rebeldia diante de dois tipos de opressão: uma política e outra erótica. Nesse sentido, há em Jícama um uso contracultural da pornografía, algo que não era insólito na época: naqueles dias, a revista Caballero, dirigida pelo jornalista James Fortson e que havia se estruturado como uma versão mexicana da Playboy, havia sido um emblema de independência e uma rajada de ar fresco para o mundo das publicações jornalísticas da época. ${ }^{37} \mathrm{Na}$ rebeldia juvenil daqueles anos, a oposição ao discurso político e aos valores da moral sexual convencional podiam andar de mãos dadas.

O filme termina com uma montagem em que se perdia o tom irônico-humorístico que havia predominado no trabalho. Mostrava uma caricatura de Hitler e passava para uma frase que dizia, "Missão cumprida: Gustavo Díaza Ordaz”, em seguida para uma edição

37 Sobre o controle da imprensa durante o sexênio de Gustavo Díaz Ordaz, ver Krauze (1997, p.306-7). Sobre Caballero, ver Agustín (1990, p.214). 
combinada entre o logotipo da Unidad Habitacional Tlatelolco e as fotos de jovens mortos em 2 de outubro que haviam sido publicadas na revista Por qué?, e dando lugar a mais duas frases de propaganda: "Não ocultar a verdade" e "Direito é liberdade". Finalmente, a conclusão, agora em tom sério. Termina a música de Janis Joplin e começa um rufar de tambor que impõe um tom sério e militar. "Eu voto assim" e um corte para a última frase: "O povo no poder". E então a câmera faz um zoom no pôster clássico de Che Guevara baseado na fotografia de Korda em alto contraste.

O exercício que Jícama fazia para zombar da retórica oficial era muito semelhante ao que naqueles anos Carlos Monsiváis fazia nas páginas do suplemento Hoy en la Cultura da revista Siempre!, que terminariam por perfilar o estilo que se desenvolveu na coluna "Por mi madre, bohemios". Em um momento em que o poder governamental parecia onipresente nos meios de comunicação de massa, a ironia era o único recurso possível para indicar as contradições e os excessos retóricos do regime. Além disso, resultava em uma trincheira ideal: é difícil acusar de subversão quem se dedica a recopilar fragmentos do discurso oficial. O Estado não pode censurar seus próprios conteúdos. ${ }^{38}$ No entanto, é curioso que os membros do júri não tenham colocado a fita entre os cinco prêmios principais, uma vez que se adaptava muito às suas expectativas. Tratava-se do filme mais diretamente político do concurso, e é provável que tenham temido que isso tivesse consequências. O sentido iconoclasta de Jícama era similar à representação de I hate your generation, primeira obra de Ulises Carrión, artista que poucos anos depois teria uma importante carreira com o conceptualismo europeu dos anos 1970. Nela, um grupo de jovens dedicava-se a destruir jornais e todo tipo de mensagens, entre as quais se encontrava o edital para o próprio concurso. ${ }^{39}$

38 É um exercício semelhante ao que realizou recentemente a artista cubana Ana Brugera, ao criar um jornal no qual em vez de notícias há apenas frases revolucionárias. Ao mesmo tempo em que destacava o deslocamento da informação pelas ordens, colocava o governo cubano na situação difícil de como censurar seu próprio discurso.

39 Sobre a obra posterior de Ulises Carrión, ver Carrión (2007, p.174). 
No fundo, o que os filmes do concurso estavam debatendo era uma nova relação entre a Arte e a Política. Em 1970, a experiência de 1968 havia aberto uma discussão sobre o papel dos artistas em um movimento de caráter político e social muito diferente da que havia existido antes no país durante o século XX. Longe da posição didática e vertical do muralismo, em que a arte conformava-se como uma via para ajudar o forjamento do "homem novo" que deveria surgir da revolução mexicana, o que o movimento estudantil havia sugerido para os pintores e cineastas próximos era uma alternativa acerca das práticas artísticas e da natureza da arte que deveria ser produzida a partir de então. A colaboração dos membros do Salón Independiente e de outros pintores na pintura do "Mural efémero" na explanada da Cidade Universitária, a organização dos estudantes de La Esmeralda e San Carlos para a produção de panfletos e propaganda gráfica, ou a elaboração de documentos para a difusão das posições do movimento, haviam impactado profundamente o meio artístico. ${ }^{40}$

Um dos cinco filmes vencedores, Mi casa de altos techos, de David Celestinos, entrava em cheio no debate dessa alternativa. Celestinos, que na época tinha 27 anos, o que o situava como um dos participantes mais velhos do concurso, era pintor e havia sido estudante da Academia de San Carlos nos anos 1970. Embora, por recomendação de José Rovirosa, tenha frequentado o Cuec durante alguns meses, sempre considerou-se um cineasta autodidata. Na verdade, costumava utilizar sua câmera Yashika de Super 8 para filmar casamentos e batizados. Para Mi casa de altos techos, seu primeiro filme formal, só usou atores improvisados, amigos seus de San Carlos, e sua elaboração demorou cerca de dois meses. $\mathrm{O}$ título fazia referência ao prédio da Academia no centro da cidade. Superava os 15 minutos que os organizadores haviam estabelecido como tempo máximo (durava pouco mais de 23 minutos) e abordava a história de dois estudantes de artes plásticas com diversas preocupações e formas de entender a arte.

Eu queria deixar um testemunho de como nos havia impactado na Escola de Artes Plásticas o movimento de 68. Nós basicamente

40 Ver Mantecón (2007a; 2007b). 
nos expressamos com imagens, e certamente sempre em todos os movimentos políticos, estudantis e demais, a Escola de Artes Plásticas foi muito combativa, mas através de cartazes, desenhos, pinturas etc. E em 68 também participamos. E foi muito lamentável o golpe que nos deram, porque nós pintores sempre fomos combativos, mas nunca havíamos visto essa barbárie. E eu creio que ninguém, na verdade, no México, havia visto essa barbárie. [...] Eu queria deixar um testemunho através do cinema, porque digo: o que podemos fazer? Não podemos nos expressar, os jornais não nos publicam, havia um estado de estupidez terrível. [...] Então, fiz meu tema sobre dois estudantes, como cada um o visualiza de uma maneira. ${ }^{41}$
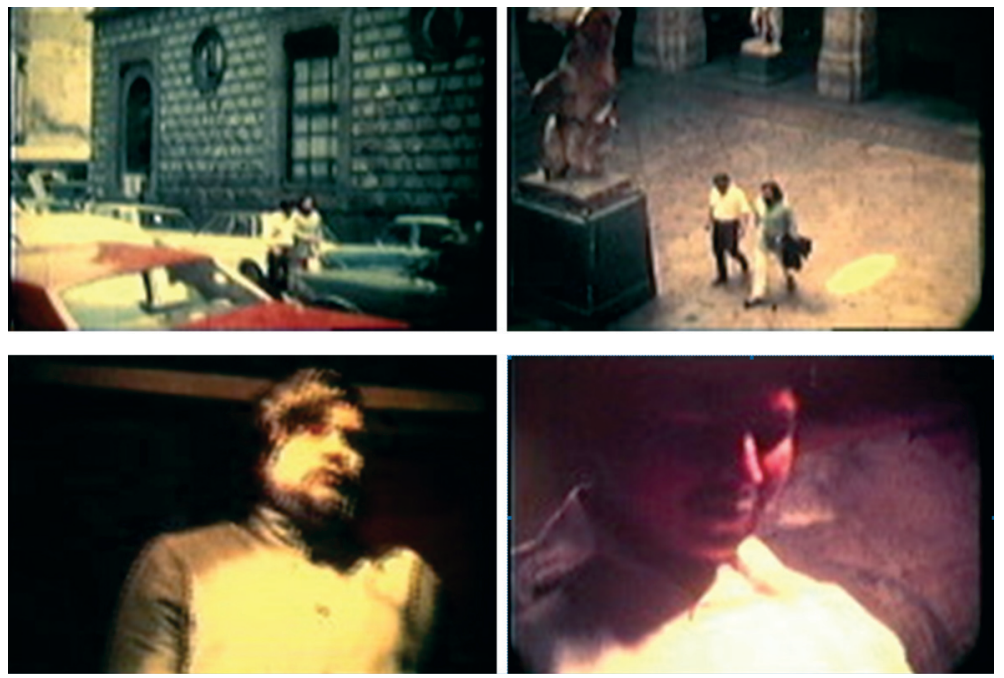

Mi casa de altos techos (1970), de David Celestinos.

Embora amigos, os dois artistas são diferentes. Um deles, com o qual o diretor mais se identificava, usa barba, cabelo comprido e está mais próximo da contracultura. O outro é de origem popular, está mais preocupado com a consciência e os temas sociais. O filme

41 Entrevista com David Celestinos por Álvaro Vázquez Mantecón, 29 de janeiro de 2005 . 
inicia-se com o encontro dos amigos na Academia. Juntos percorrem o interior e mostram um ao outro seu trabalho em uma das salas. Dali se separam. O segundo caminha pelo centro da Cidade do México, sob um fundo musical dos Beatles ("Get back"). Procura algo. Sua caminhada o conduz às cercanias da cidade, onde corre desabaladamente, como se fugisse de algo. Enquanto agora soa uma canção lenta e melancólica ("Remember love", interpretada por Yoko Ono), a voz em off diz:

Corro. Estou correndo. Por que minha angústia, meu desespero, e esse cão famélico que me olha? Já sei. As moscas. O sol quente e os despojos. Varais da minha alma infantil. Corda mole endurecida. Hei de atar e desatar. Hei de atar meu presente ao meu futuro. Minha determinação com o desejo. A força da minha vontade com a esperança. Desatar o que unido estava esquecido. Perdido. Impedindo-me a tranquila visão do horizonte. Minha pegada infantil. $\mathrm{O}$ voo dos pássaros. O aroma das flores.

O personagem chega a uma zona marginal. Em um depósito de lixo, ao lado de um cão morto, pega uma ratoeira, que examina minuciosamente. Em seguida aparece uma imagem simbólica: um menino, situado à contraluz com uma auréola que dá à composição um tom de sacralidade, amarra uma corda grossa.
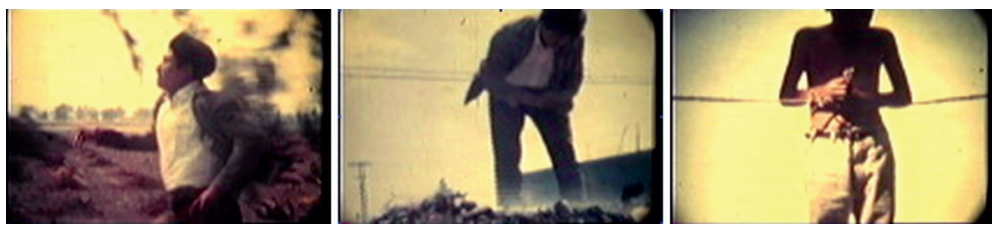

Mi casa de altos techos (1970), de David Celestinos.

Seu companheiro, o contracultural, também pondera. Mas, mais que a miséria, atormentam-no outras coisas, como sua própria existência, a repressão política, o amor. Aparece em uma sequência recostado, o início de uma sequência sobre o fio de seus pensa- 
mentos. Sobre o fundo musical do Réquiem de Mozart, a câmera mostra o interior de seu estúdio, com pinturas matéricas e de estilo expressionista abstrato, com um pôster do Che Guevara, e onde uma parede mostra, entre jorros de tinta, a legenda " 2 de outubro". $\mathrm{O}$ artista está angustiado por dúvidas existenciais, que se escutam em off junto ao seu lamento sobre a repressão de 68: "O desejo ou a esperança. Minha angústia. $\mathrm{O}$ sofrimento ou o protesto. $\mathrm{O}$ mundo que me cerca e me aniquila. Minha legítima aspiração truncada pelos grilhões. Não sei. Não sei. Sei?”. Seu pensamento leva-o a uma festa desvairada, marcada pelo som de tambores, onde os assistentes dançam em êxtase. Mas isso tampouco o satisfaz e suas dúvidas continuam: "É a luz que me cega nova chama? Será a certeza secreta de outra aurora, a coroação da minha força, o poder do povo e a oferenda ao céu? Não sei. Sei? Não sei”.

Termina sentado, catatônico, em postura de meditação. Uma mulher aproxima-se e coloca as duas mãos sobre a cabeça dele. Isso dá lugar a uma nova dissertação sobre o amor acompanhada de imagens em que ele caminha com sua companheira pelo campo. Em off, Yoko Ono regressa com a canção "Remember love".
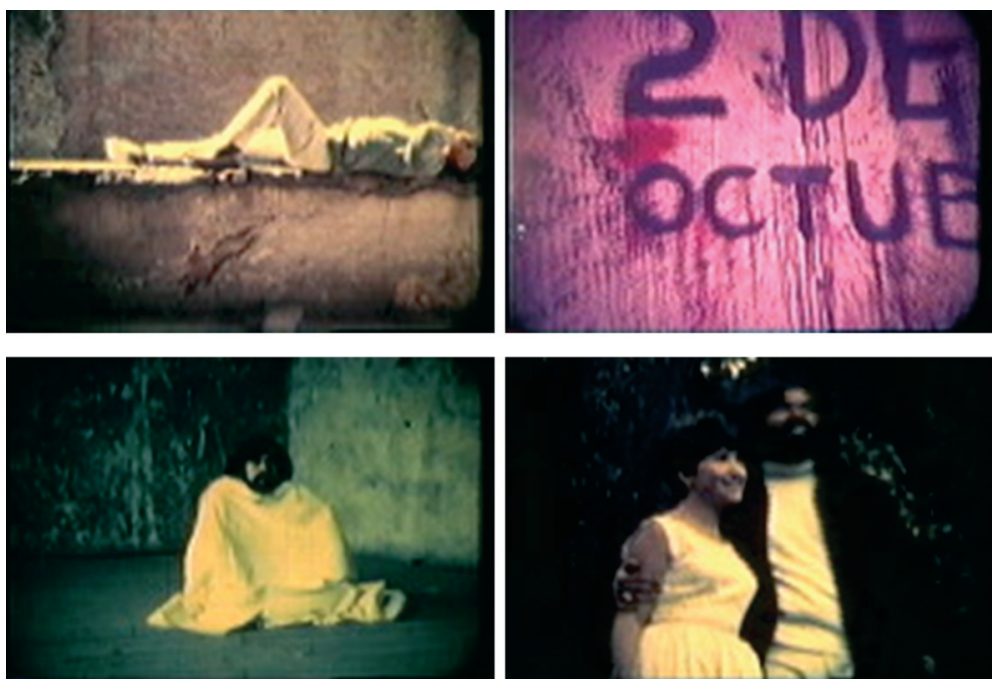

Mi casa de altos techos (1970), de David Celestinos. 
O corte é abrupto. Reaparece o pintor social, refletindo sobre a luta. Agora, na metáfora a corda se desata, dando ensejo a uma série de imagens vertiginosas, nas quais aparece um estúdio onde se misturam a arte e as palavras de ordem. Em uma parede, a palavra "Destruição", enquanto o artista agita com força um lenço branco e escuta-se uma voz em off sobre um fundo musical de John Lennon ("Give peace a chance"), fazendo um discurso sobre a luta, a solidariedade e a vitória:

Venceremos. Vencerei. Venceremos. Vencerei. Venceremos aqueles que nos proibiram os caminhos. Aqueles que põem preço ao bem-estar do homem, o encarceram e o humilham, e corrompem o amor mais puro. Agora caminharemos juntos. Um ao lado do outro, solidários. Estreitaremos as mãos para sempre. Derrotaremos a canalha que cega as fontes, mutila o talo jovem e envenena o ar. $\mathrm{O}$ sangue derramado cem vezes frutifica na voz. Na imagem, no riso, nas ondas sonoras. Subiremos a encosta onde cante a vida. Onde o campo reverdeça e as pombas libertadas levantem voo.

No fim do filme, uma vez mostradas suas inquietações e aspirações, os dois amigos reencontram-se e caminham mais uma vez para o interior da Academia, como uma metáfora à volta à origem da história.

Os críticos destacaram-na do conjunto. Jorge Ayala Blanco reconhecia em sua crítica que era a fita "mais grave e reflexiva do concurso", e que contava com "um esmerado trabalho de representação" (1986, p.350). Sua maneira de expor um tema central para o debate do momento foi bem recebida pela crítica. A Emilio Arízaga, a fita pareceu "enfada um pouco, talvez, mas o desafio a que o diretor se impôs era muito grande (...). A impressão que dá é a de alguém que segue com um passo firme e sereno, alheio a improvisações ou transbordamentos". ${ }^{42}$

42 Emilio Arízaga, "Continua a boa qualidade dos filmes do Concurso de Cinema Independente”, Op.Cit. 
Em grande parte, Mi casa de altos techos destacou-se por sua capacidade de pôr no centro da discussão o debate sobre o impacto de 1968 na arte, o que foi fundamental na apreciação que teve no momento. O que se punha em relevo era o tema da consciência. Outro filme que obteve menção honrosa no Concurso, El padre ou Why?, de Enrique Escalona e Galo Carretero, fazia uma exposição sobre o que acontece do outro lado da tranquilidade da vida burguesa. Alternavam-se imagens de placidez doméstica da classe média com cenas da guerra do Vietnã e das rebeliões estudantis da época. No final do filme, sobre a fotografia de um comício em Tlatelolco, uma pergunta: "saber, dar-se cuenta, quando?" (idem, p.349).

Entretanto, nem todas as fitas que foram destacadas pelo júri do concurso eram motivadas pelo tema da política. Esse foi o caso de Sur, dirigido por Gabriel Retes e que obteve uma menção honrosa, que narrava uma história do Oeste, embora com um tratamento livre e contracultural.

Retes contou a história da filmagem da seguinte maneira a Eduardo de la Vega (1999, p.25-8):

Soube do edital e tomei a decisão, muito apressada porque o tempo já era curto, de fazer um filme para o concurso. E acho que neste caso influiu, para o bem ou para o mal, minha formação precária, porque eu não sabia [como] os roteiros eram escritos; embora eu tenha visto o roteiro de Cristo 70, não tinha ideia de que fossem necessários. Então me ocorreu uma ideia de filmá-lo nos Dínamos de Contreras ou perto do monte Ajusca. Minha ideia era fazer um western, eu adorava os westerns, na verdade continuo gostando muito deles, e foi então que fiz Sur; eu o filmei sem roteiro e de forma improvisada. Fizemos tudo em 3 ou 4 dias; como não tínhamos dinheiro para alugar cavalos, consegui alguns paus e uns balanços. Então filmei com telefoto e no filme, de repente, veem-se uns tipos que surgem debaixo de uma lombada, que vêm cavalgando e conforme se aproximam se vê que na verdade vêm trotando sem cavalos. Depois, as cenas de violência, as mortes típicas do western, 
nós as filmamos com pistolas de água nas quais colocamos anilina vermelha para sugerir sangue etc.

O título vinha do jogo de palavras "West/Oeste", que dá origem a "western". Alegava a posição sulista do México em relação ao velho oeste norte-americano, e por isso se chamava Sur. No início do filme, sobre o título, uma voz em off o explicava: "Sur: um western aqui deste lado". Retes poderia tê-lo chamado de "Norte", e teria sido mais correto com o ponto de vista que a geografia do país implica com respeito aos Estados Unidos. Talvez sua decisão indique uma perspectiva inconscientemente colonizada. Entretanto, realizar um filme sobre o Oeste não era estranho. $O$ gênero havia tido certo enraizamento no país desde os anos 1950, quase sempre adaptando as histórias do Oeste ao norte mexicano, como fizera de maneira emblemática Los hermanos del Hierro (1961), de Ismael Rodríguez. ${ }^{43}$ Mas em Retes percebia-se uma certa influência dos filmes de Sergio Leone que haviam dado forma ao spaguetti western e haviam causado um profundo impacto em muitos jovens dos anos 1970, como já vimos no caso de El fin, de Sergio García. ${ }^{44}$

O xerife do filme era interpretado por Fernando Balzaretti, primo de Retes e que iniciava sua carreira como ator. Acendia de forma pomposa um cigarro que nunca saía de sua boca, em uma clara paródia do personagem de Clint Eastwood nos filmes de Leone (Por um punhado de dólares, 1964, e Três homens em conflito, 1966). Retes também acompanhava com atenção o diretor italiano no tratamento visual. Fazia um uso mais que generoso dos close ups de e planos contínuos em que o rosto irrompia na paisagem ou vice-versa.

Diferentemente dos outros participantes do concurso, Retes contava com uma boa câmera que lhe permitia realizar aproxima-

43 Durante os anos 1950, destacaram-se os filmes dirigidos por Rafael Baledón, como La flecha envenenada (1957), El pantano de la muerte (1957) ou El potro salvaje (1958).

44 Há também no cinema industrial mexicano daqueles anos uma clara influência dos filmes de Leone. Ver os filmes dirigidos por Alberto Mariscal, como El silencioso (1967), El Tunco Maclovio (1970) ou El sabor de la venganza (1971). 
ções e estabelecer uma relação de profundidade de campo entre personagens e paisagem. Neste, que era seu primeiro filme, percebia-se uma preocupação com a perfeição e uma aspiração ao grande cinema. Por exemplo, na busca da boa qualidade de imagem, Retes costumava filmar 24 quadros por segundo, em vez de 18, velocidade comum usada pelos usuários do Super 8 que queriam economizar material. ${ }^{45}$
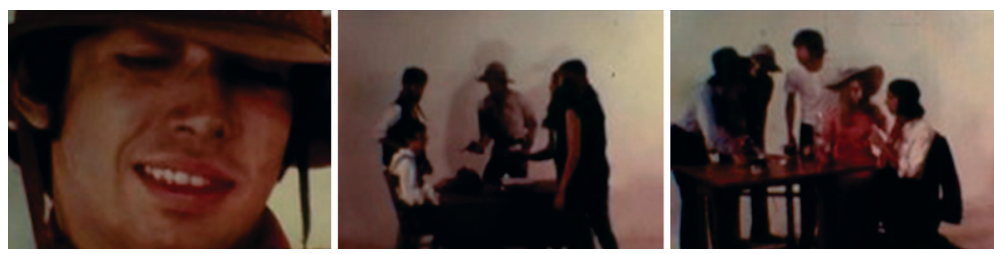

Sur (1970), de Gabriel Retes. Close up nos créditos iniciais. Diorama para cena de assalto ao banco e à taverna.

Em Retes percebia-se uma grande imaginação cinematográfica. Mais que vaqueiros, os personagens parecem hippies da época: usam cabelo comprido, faixas no cabelo, as mulheres usam calças compridas etc. Não há nenhuma intenção por parte do diretor de ser historicamente fiel ao Oeste do século XIX. A música, embora precária (um violão acústico e uma harmônica), é demasiado próxima do rock. Ele usa um diorama em fundo branco para representar dois lugares distintos (um banco e uma taverna). Em uma sequência muito criativa, para solucionar a ausência de cavalos devido ao baixo orçamento, apresenta os ginetes no bosque usando a profundidade de campo da câmera. Enquanto no primeiro plano se vê um montículo com folhagem, ao longe percebem-se os personagens trotando. Mas quando passam diante da câmera, um plano nos faz ver que não têm cavalos, mas simulam o galope.

45 Entrevista com Gabriel Retes por Álvaro Vázquez Mantecón, Op.Cit. 

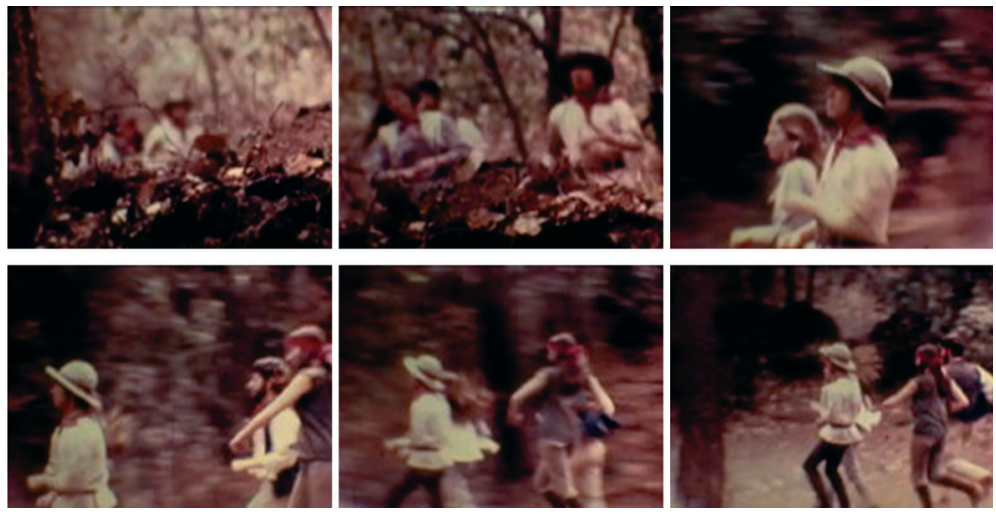

Sur (1970), de Gabriel Retes. Sequência dos ginetes.

Mas, fossem os filmes políticos ou não, o concurso foi como uma fotografia das preocupações e formas de expressão da juventude da classe média mexicana nos anos posteriores a 1968. Como vimos anteriormente, os jornalistas que seguiram as projeções foram os primeiros a surpreenderem-se com a boa qualidade das fitas. Mas houve quem tivesse a sensação de estar enfrentando algo completamente novo. Em sua coluna jornalística "Miscelânea cultural (ou quase)", Nancy Cárdenas mostrou seu entusiasmo pelos resultados do concurso, embora também assinalasse que eram "praticamente nulos no terreno estético", e chegou a se perguntar abertamente se havia aparecido um novo cinema underground no país. ${ }^{46}$

Tendo em vista a agitação originada pelo concurso, uma jornalista foi entrevistar Juan José Gurrola, que enfatizou as possibilidades desse tipo de filme, que evita as complicações do cinema industrial ("um processo lento, tortuoso e ditirâmbico de produtores, técnicos, sindicatos, maquiadores, script-girls e iluminadores”) para se concentrar na expressão de ideias para criar expressões sutis e ao mesmo tempo sinceras:

46 Nancy Cárdenas, "Underground habemus?" na coluna "Miscelânea cultural (ou quase)”. Recorte hemerográfico no arquivo de Sergio García. 
O importante é que a qualquer realizador jovem não importa investir uma pequena soma de dinheiro em dizer o que quer, enquanto os produtores gastam milhões para tentar expressar o que nem sequer sabem. Pessoalmente, advirto que a indústria cinematográfica não nos interessa: para terminar logo, ficam perdidos no espaço. Nós temos tentado conservar uma linha definida; o contrário conduz ao vazio. ${ }^{47}$

Havia a sensação compartilhada de haver encontrado uma alternativa para superar uma crise do cinema mexicano que na época já parecia ser endêmica. Os organizadores declararam que realizariam mais concursos no futuro, e que provavelmente os ampliariam para $16 \mathrm{~mm}$. Inclusive chegaram a pensar em dar-lhe uma projeção para a América Latina. ${ }^{48}$ Arturo Garmendia (1970), que havia feito a resenha do certame no jornal Esto, aventurava-se a dizer que o Concurso "talvez fosse o início de uma corrente". E em grande parte foi.

Os filmes exibidos começaram a circular em cineclubes da Cidade do México e de algumas cidades da província. As pessoas não cabiam na galeria Munch de Lepoldo Ayala, onde foram inicialmente projetados, e conseguiu-se permissão para exibi-los no Teatro Reforma (García, 1973, p.35). David Celestinos e Alfredo Gurrola decidiram enviar seus filmes para festivais internacionais. Mi casa de altos techos e El tercer suspiro participaram do concurso de cinema de 8 mm em Tóquio, no Japão, onde receberam menção especial. Gurrola também enviou seu filme para o $31^{\circ}$ Concurso de Cinema Amador de Sidney, na Austrália. É preciso dizer que no futuro não seriam muitos os filmes mexicanos em Super 8 que iriam para o estrangeiro.

Mas o certo é que se percebia certa euforia participativa. E não era para menos. Havia-se encontrado uma nova maneira de fazer cinema, havia-se consolidado um novo circuito de exibição, e os fil-

47 Socorro Díaz, Op.Cit.

48 "Foram entregues os prêmios do primeiro concurso de cinema em 8 milímetros. Luis Buñuel assinou os diplomas e aceitou que se instituísse um prêmio com seu Nome para o próximo evento.” El Día, 26 de maio de 1970. 
mes pareciam ser cortados com um mesmo padrão, que vaticinava a conformação de um modelo para o debate e a discussão de temas que, como a política, não puderam ser tratados diretamente pelo cinema. Em Excelsior, Ayala Blanco (1986, p.353) comentou que no concurso percebia-se um

clima de "estilo geracional" que tenta relações acusadas entre radicalismo ideológico (pré-revolucionário) e o cinema. [...] É a aportação impaciente deste inaugural cinema underground de $8 \mathrm{~mm}$ e à mexicana, valioso testemunho de um relevo geracional que pretende dar espessura e profundidades intensas à confusão de suas certezas, e talvez dar corpo a uma tomada de posição. ${ }^{49}$

Certamente, o concurso havia estabelecido uma linha de discussão, a da complexa relação entre a Arte e a Política, que seria o eixo discursivo de um movimento cinematográfico em seus primórdios.

\section{Considerações finais}

Seguimos nestas páginas a história da origem do movimento do cinema Super 8 no México no ano de 1970. Os filmes inscritos no Primeiro Concurso Luis Buñuel foram obras de arte elaboradas na marginalidade da cultura, algo que as dotava de uma liberdade sem precedentes e como produtos claramente contraculturais. Apesar da juventude de seus criadores, eram fitas que representam com clareza os interesses de uma geração profundamente agravada pela repressão política e que havia encontrado em 1968 um emblema.

É precisamente por sua marginalidade que se revestem de uma importância fundamental para os historiadores de hoje: constituem um testemunho da maneira de entender o mundo de uma geração de jovens latino-americanos que romperam com o mundo herdado de seus pais. A nova narrativa do imaginário dessa geração conduz

49 Jorge Ayala Blanco, Op.Cit., p. 353. 
necessariamente à discussão sobre a noção de contracultura nas sociedades subalternas. A partir da análise dos filmes em Super 8, fica claro que não é a mesma coisa escutar os Beatles em Liverpool em 1967 ou Bob Dylan em Nova Iorque em 1965 e ouvir esses mesmos artistas na Cidade do México em 1970. A música será a mesma, mas o fenômeno de repetição que ela implica é radicalmente diferente. Nesse sentido, a valorização da contracultura latino-americana em geral e mexicana em particular requer a análise detalhada das condições de formação de estratégias de identidade no capitalismo tardio. A revisão desses filmes conduz, por outro lado, ao entendimento da mudança da agenda e dos temas de discussão na cultura mexicana do final dos anos 1960 e princípio dos anos 1970. Percebe-se, nesse caso, a inclusão da política na arte de um ponto de vista amplo e o deslocamento de uma prática artístico-burguesa convencional e da experimentação em novos suportes e novas formas de produção.

\section{Referências bibliográficas}

ALFARO, E. De la V. Le scommesse di Retes. Venecia: Edizioni APLCAI, 1999, p.21-2.

AGUSTÍN, J. La tragicomedia mexicana 1. La vida en México de 1940 a 1970. México: Planeta, 1990, p.214.

La contracultura en México: México: Grijalbo, 1996.

AYALA BLANCO, J. La búsqueda del cine mexicano. México: Editorial Posada, 1986.

CARRIÓN, U. El nuevo arte de hacer libros. In: DEBROISE, O. (Ed.).

La era de la discrepancia: arte y cultura visual en México, 1968-1997. México: Unam-Turner, 2007, p.174.

DEBROISE, O. (Ed.). La era de la discrepância: arte y cultura visual en México, 1968-1997. México: Unam-Turner, 2007.

FOLEY, M. El recogedor de soles: la vida y la obra de Feliciano Béjar. México: Centro Cultural San Ángel, 1992.

GARCIA RIERA, E. Breve historia del cine mexicano: primer siglo, 1897 1997. México: Imcine, 1998.

GARCÍA, S. Hacia el $4^{\circ}$. cine. Zacatecas: Editorial Universitaria, 1973. GARMENDIA, A. O melhor: o cinema marginal. Esto, 26 dez. 1970. 
GERMENOS, P. G. Salón Independiente: una relectura. In: DEBROISE, O. (Ed.). La era de la discrepancia. Arte y cultura visual en México, 1968-1997. México: Unam-Turner, 2007, p.40-7.

KRAUZE, E. La presidencia imperial: ascenso y caída del sistema político mexicano (1940-1996). México: Tusquets, 1997.

LERNER, J. Consumed by a fever: the small-gauge cinema of Orizaba's Sergio Tinoco Solar. In: Film History: An International Journal, v.15, n.2, 2003, p203-7.

Superocheros. In: Wide Angle, Ohio University School of Film, v.21, n.3, jun. 1999.

MANTECÓN, Á. V. La visualidad del 68. In: DEBROISE, O. (Ed.). La era de la discrepancia. Arte y cultura visual en México, 1968-1997. México: Unam-Turner, 2007a.

MANTECÓN, Á. V. (Comp.). Memorial del 68. México: Unam-Turner, 2007b.

MARTÍNEZ, M. del C. El café donde moran las musas. In: Wide Angle, Ohio University School of Film, v.21, n.3, p.12, jun. 1999.

MARWIK, A. The sities: cultural revolution in Britain, France, Italy, and United States. c.1958-c.1974. Oxford-New York: Oxford University Press, 1998, p.11.

MONSIVÁIS, C. Amor perdido. México: Era-SEP, Lecturas Mexicanas 44, 1986. (primera edición de 1977)

. La naturaleza de la onda. In: Amor perdido. México: EraSEP, Lecturas Mexicanas 44, 1986, p.225-62.

Número 600, cultura, incultura y contracultura. In: La cultura en México, suplemento de Siempre!, México, 8 ago.1973.

RIERA, E. G. Breve historia del cine mexicano. Primer siglo, 1897-1997. México: Imcine, 1998, p.256-8.

SERRANO, A. Está sendo organizado un concurso de cinema experimental cujo prêmio é participar de certames internacionais. In: El Heraldo. Zacatecas: Editorial Universitaria, 1973, p.25.

TORRELLA, J. Crónica y análisis del cine amateur español. Madrid: Rialp, 1965.

ZOLOV, E. Rebeldes con causa: la contracultura mexicana y la crisis del Estado patriarcal. México: Norma, 2002.

\section{Hemerografia}

"Concurso Nacional de Cine". Excélsior, sexta-feira, 29 de maio de 1970. 
"Foram entregues os prêmios do primeiro concurso de cinema em 8 milímetros. Luis Buñuel assinou os diplomas e aceitou que fosse instituído um prêmio com seu nome para o próximo evento”. El Día, 26 de maio de 1970. ARÍZAGA, E. "Continua a boa qualidade dos filmes do Concurso de Cinema Independente". El Día, 27 de maio de 1970.

"Terminou a exibição privada dos filmes do Concurso em 8 milímetros". El Día, 30 de maio de1970.

DÍAZ, S. "Fala Juan José Gurrola. Filmes de 8 milímetros para cineastas inquietos". El Día, 29 maio de 1970.

GARMENDIA, A. "O melhor: o cinema marginal". Esto, 26 de dezembro de 1970.

MONSIVÁIS, C. "Número 600, cultura, incultura e contracultura". In: La cultura en México, suplemento de Siempre!, México, 8 de agosto de 1973.

\section{Entrevistas}

Entrevista com Alfredo Gurrola por Álvaro Vázquez Mantecón, 5 de abril de 2005.

Entrevista com David Celestinos por Álvaro Vázquez Mantecón, 29 de janeiro de 2005.

Entrevista com David Celestinos por Álvaro Vázquez Mantecón, 29 de janeiro de 2005.

Entrevista com Gabriel Retes por Álvaro Vázquez Mantecón, 8 de setembro de 2005.

Entrevista com Óscar Menéndez por Álvaro Vázquez Mantecón para o Memorial del 68, Centro Cultural Universitario Tlatelolco, UNAM, 1 de agosto de 2006.

Entrevista com Sergio García por Álvaro Vázquez Mantecón, 19 de abril de 2005.

Entrevista com Felipe Tirado por Álvaro Vázquez Mantecón, 14 de outubro de 2008. 



\section{6 \\ SINTONIA COM O CONTEMPORÂNEO: \\ A TV COMO OBJETO E FONTE DA HISTÓRIA}

Áureo Busetto ${ }^{1}$

\section{História desligada da TV}

A televisão atualmente apresenta avanços significativos no uso da tecnologia digital, a qual permite ao meio operar imagens em alta definição, disponibilizar transmissão interativa, além de viabilizar a transmissão móvel. Essa nova configuração da TV abre toda uma sorte de antevisões sobre o desenrolar da produção televisiva e de sua recepção no futuro próximo. Ensaios acadêmicos, sobretudo da Sociologia da Comunicação, e o discurso de parte dos agentes integrados ao mundo midiático enunciam e anunciam, como elementos do passado, os programas televisivos fechados e prontos e a preponderância da audiência no recesso doméstico.

No âmbito teórico, a classificação de Umberto Eco (1986) sobre a trajetória da TV - a qual está centrada na distinção entre "paleotelevisão" e "neotelevisão" - é desdobrada, ou, por vezes, dada como suplantada. Para muitos teóricos, os principais elementos e dinâmicas do futuro da TV já estão dados. Assim, o mundo caminha, a passos largos, para a era da pós-televisão, como prenunciado por

1 Doutor em História e professor da Unesp - Assis, é autor de A democracia cristã no Brasil: princípios e práticas. São Paulo: Editora Unesp, 2002. 
George Gilder (1996) desde os anos 1980, ou vivencia o fim da televisão, segundo perspectiva de Jean-Louis Missika (2006). Trata-se, entretanto, do fim da TV que conhecemos, ou pensamos conhecer.

O debate teórico tem englobado questões sobre as possibilidades que se abrem à democratização da comunicação eletrônica, em geral, e da televisão, em particular. Contudo, as discussões continuam a desenrolar-se aferradas à dicotomia entre "apocalípticos" e "integrados", posicionamentos com relação à mídia que foram tão bem definidos por Umberto Eco (1986). Os primeiros nada concedendo de positivo à televisão, os segundos aderindo, quase totalmente, ao meio, quando não de maneira alumbrada.

$\mathrm{Na}$ temporalidade histórica, a televisão já conta com quase oitenta anos como tecnologia. Está perto de completar seis décadas como um fenômeno industrial, social e estético. Conta com dois decênios de constantes e aceleradas alterações em suas esferas de produção, divulgação e recepção, posto que a primeira geração formada e tocada pela televisão constituiu-se nos anos 1980, fenômeno que gerou possibilidades para maior experimentação e emprego de novas linguagens próprias do meio.

Entretanto, o recorrente debate teórico sobre a TV, a trajetória histórica do meio - que há muito desfruta de certa soberania no universo da comunicação social - e a participação da televisão nas alterações da vida social e cultural contemporânea parecem não constituir-se ainda em elementos suficientes para que historiadores integrem a produção televisiva ao rol de suas fontes de pesquisa ou passem a tomar o meio como objeto de seus estudos. Tal situação revela o desligamento da História com a TV e, por extensão, uma História sem sintonia com questões ligadas a um conjunto de amplas e constantes relações sociais, culturais e políticas que a televisão tem integrado na contemporaneidade.

Em relação à televisão, a historiografia do contemporâneo apenas faz constar menções ou citações bastante pontuais e restritas sobre a existência do meio, ou acerca de alguns aspectos gerais do impacto ocasionado pela TV na vida social contemporânea. Menções ou citações coladas a teorias e análises sobre o meio e seu funcionamento 
que são elaboradas, sobremaneira, por estudos sociológicos ou da área de Comunicação. Teorias ou análises que, em regra, tendem à perspectiva ahistórica ou trans-histórica. Direção teórica que, podemos dizer, acaba por tratar a televisão com base em um pensamento essencialista (com essência e substância em si mesmo) - lembrando aqui as assertivas de Pierre Bourdieu (1996) acerca de uma das principais características dos estudos dos bens culturais. Encerra o meio em um "presente perpétuo". Faz tábula rasa das relações sócio-históricas que criaram um campo de possibilidades para que representações e práticas próprias do universo televisivo fossem legitimadas e reconhecidas socialmente. Corrobora com a ideia de que a televisão é tão somente um veículo transmissor da cultura, logo, distante da noção que a define como meio portador de uma cultura própria.

Colada às teorias e análises sobre a TV, e sem sequer trazer uma pontual nota de rodapé com críticas acerca da natureza ahistórica/ trans-histórica dos pressupostos teóricos sobre o meio, a historiografia ocupada com o estudo da contemporaneidade revela, de um lado, sua desconsideração à ideia de que a televisão possa ser um objeto digno dos estudos históricos, e, de outro, reforça indiretamente a noção de que os estudos sobre o meio são próprios somente das áreas de Comunicação e Ciências Sociais. Pode-se questionar se o desligamento da historiografia do contemporâneo com relação à TV não é, em parte, fruto de receios dos historiadores em tratar de um fenômeno multifacetado, logo, um objeto de estudo fugidio a uma chave única de interpretação, posto ser a televisão um fenômeno ao mesmo tempo tecnológico, industrial, social e estético.

Ainda que os estudos ocupados com o cinema e a imprensa tenham sido crescentes na historiografia sobre o contemporâneo, os estudos que se inscrevem nessas chaves não têm servido de estímulo para que a TV cresça e apareça no rol dos "novos objetos da História" e a produção televisiva seja tomada como fonte da pesquisa histórica. Situação paradoxal quando se leva em conta que as pesquisas históricas sobre a imprensa e o cinema ocupam-se de práticas e representações tão próximas às da TV ou que sofreram alterações significativas com o avanço do meio nas últimas seis décadas. E, em 
grande medida, isto ocorre em razão dos estudos históricos sobre o cinema e a imprensa não abrirem espaço ao tratamento das relações desses dois meios com a TV.

No âmbito da história da imprensa, para tratar de seara mais conhecida pelo autor deste texto, os jornais e as revistas de variedades têm servido como fonte para uma ampla série de pesquisas históricas sobre temáticas contemporâneas e, em menor intensidade, como objeto de pesquisa. Mas o telejornalismo não tem constado no rol de fontes dos estudos ocupados com períodos mais recentes da história da imprensa.

Nesses estudos, quando muito, o que se vêé a repetição da prática de citações e menções ancoradas em teorias sociológicas ou da área da Comunicação sobre a televisão, ou mais especificamente dirigidas ao telejornalismo. Assim, a prática reinante é a da desconsideração do telejornalismo como objeto e fonte da pesquisa histórica sobre a imprensa, prática confirmada na ausência de notas ou parágrafos explicativos acerca das razões de o autor/historiador não contemplar em seus estudos históricos sobre a imprensa uma prática jornalística que existe há mais de meio século: o telejornalismo.

Por incrível que possa parecer, o telejornalismo e sua produção sequer são tratados de maneira indireta nos estudos históricos sobre a imprensa, notadamente no caso brasileiro. Historiadores da imprensa não se ocupam em conhecer quanto do material jornalístico publicado é devido à concorrência geral entre jornalismo impresso e telejornalismo, aos intercâmbios de práticas entre as duas formas de fazer jornalismo, às cumplicidades tácitas ou aparentes entre os dois tipos de jornalismo. E tampouco eles buscam mensurar o quanto do material jornalístico selecionado é resultante de fatos como: o periódico consultado ou analisado integra-se a um conglomerado comunicacional que conta com emissora de TV; o proprietário do jornal encontra-se na luta por uma concessão televisiva; ou, ainda, o dono do jornal não dispõe de canal televisivo, quer em função de sua crença na autonomia do jornalismo impresso em relação ao telejornalismo - uma vez que a operação de uma emissora de TV depende de concessão do poder público -, quer simples- 
mente por dificuldades financeiras que o impeçam de ingressar no campo televisivo. Assim, o jornalismo impresso e o telejornalismo são tomados como produtos elaborados em domínios sociais com distância intergaláctica e sob atmosferas radicalmente distintas, como se a história da imprensa não englobasse essas duas formas de jornalismo e a imprensa não estivesse integrada à grande chave história da comunicação social.

E o desligamento da História com relação à TV somente não tem sido absoluto em razão de uns raros historiadores terem se dedicado à realização da história do meio, como são os casos pioneiros e lapidares de Asa Briggs e Jean-Nöel Jeanneney, casos lapidares não apenas pelo pioneirismo de Briggs e Jeanneney como introdutores da TV como objeto de estudo no âmbito historiográfico de seus países, mas, sobretudo, pelo empenho deles na formação de quadros de pesquisadores, de grupos de pesquisa propulsores da história da televisão e da produção televisiva, atividades realizadas acertadamente com base na interdisciplinaridade. Mas o mais importante, Briggs e Jeanneney, em seus estudos sobre a TV, nunca descuidaram do fazer próprio do historiador, e sempre preconizaram que somente há sentido em ser um historiador da televisão - ou de qualquer mídia - caso seja-se também um historiador do social e da cultura. Ademais, os estudos de ambos os historiadores sobre a televisão não perdem de vista a relação deste meio com outras formas de mídia, quer impressa, quer eletrônica. Enfim, inscrevem-se, de maneira fértil, na chave da história da comunicação social.

O que também se deve frisar acerca dos estudos históricos sobre a radiodifusão elaborados por Briggs e Jeanneney é que eles entram na pauta de suas preocupações de pesquisa justamente quando a organização da comunicação social eletrônica em seus países passava por significativas mudanças, as quais eram debatidas por diversas e várias instâncias da vida social, sem, contudo, dispor de contribuições de conhecimento da área de História. Quando cada um deles, em momentos bastante distanciados, lançou-se à pesquisa histórica da radiodifusão, seus países de origem vivenciavam a quebra do monopólio estatal no setor de emissão televisiva. 
Asa Briggs iniciou seus estudos em 1958. Nesse ano, o mundo televisivo britânico contava com pouco mais de dois anos de funcionamento da Independent Television (ITV), primeira emissora europeia comercial e concorrente direta da pública British Broadcasting Corporation (BBC), a qual operava serviço de emissões regulares desde 1936, embora com interrupção entre 1939 a 1945, devido à Segunda Guerra Mundial. Em 1961, Briggs trazia a lume seu primeiro volume de The history of broadcasting in United Kingdon, o qual seria seguido, até 1995, por mais quatro outros volumes. A essa coleção somaria ainda três outros volumes ocupados com a história da radiodifusão britânica, os quais englobavam a televisão.

A leitura de seus volumes não apenas possibilita conhecer a história do objeto explicitado em seus títulos, mas oferece, ademais, um conjunto de informações acerca do desenrolar de seu trabalho de pesquisa em termos de problemáticas, aspectos teórico-metodológicos e de acesso às fontes, constituindo-se, ao mesmo tempo, em um manancial de aprendizagem à pesquisa histórica sobre a radiodifusão/televisão e em um breviário da história da pesquisa histórica britânica voltada ao estudo da comunicação social eletrônica.

Em um artigo publicado originalmente na revista Média, Culture $\mathcal{E}$ Society, e depois reunido em livro de textos de sua autoria, Briggs (1991) historia e analisa grande parte de sua trajetória e de sua pesquisa ocupada com a radiodifusão e a BBC, bem como, na introdução àquela coletânea de textos, apresenta suas considerações sobre o ensino e a comunicação, além de muito brevemente comentar sobre o estranhamento de seus pares com relação à sua dedicação aos estudos históricos sobre a radiodifusão.

Jean-Nöel Jeanneney iniciaria seus estudos sobre a televisão na passagem da década de 1970 para 1980, dado que o governo francês autorizaria, após algumas discussões, o início da concorrência privada às emissões públicas da TV France. Jeanneney organizaria e teria publicado o livro Télévision, novelle mémoire (1982). Escreveria ainda dois longos e férteis capítulos sobre a história da televisão na Europa e nos Estados Unidos, ambos integrados ao seu livro Une histoire des Médias - no mesmo ano de sua publicação, o livro 
contaria com uma versão portuguesa sob o título Uma história da comunicação social (1996).

Para ambos os historiadores, a definição de que a História não se restringe ao passado, posto que se abre ao presente, parece não ser mera retórica, pois não tardaram em aplicar tal orientação a temas candentes da comunicação social em seus países, subsidiando com conhecimento histórico o debate sobre a regulamentação e funcionamento do setor de emissões televisivas. Todavia, eles não se deixaram enredar nas armadilhas do presente vivido, que, no caso da televisão, apresentava-se polarizado entre a defesa saudosista do modelo público e a defesa eufórica do modelo comercial.

Seus estudos históricos sobre a televisão guardam em comum, além da interdisciplinaridade, uma abordagem da TV como instituição, uma indústria e suas organizações, moldadas pela política governamental e pela administração corporativa, embora o foco de análise de Briggs se prendesse, na maioria de seus estudos, a um espaço nacional determinado, o britânico, e o de Jeanneney se abrisse para além do território francês, notadamente aos principais países da Europa ocidental e aos Estados Unidos, apresentando, em alguns pontos, uma espécie de história comparada. Entretanto, nas obras de Briggs e Jeanneney a análise histórica do material televisivo fica em plano inferior, porém, não sem marcarem diferenças significativas em relação ao que se conhecia e como se fazia a história da TV em seus países, uma vez que, sem dúvida, legaram historicidade aos estudos da televisão.

Na década de 1990, alterações fomentadas pelas novas tecnologias e pelo recente ambiente regulador geravam mudanças na estrutura e na dinâmica da produção, da divulgação e do consumo televisivos (como oferta abundante de canais a cabo, desarticulação da TV da ideia de comunidade nacional, uso de controversas estratégias de sedução e fidelização da audiência, fragmentação do público em faixas de mercado calcado no gosto, hegemonia de novos gêneros e formatos, como talk show e reality show), além de prognósticos acerca do fim da televisão, constituíram-se em fatores que conduziriam os estudos da TV na área de Comunicação a abrirem- 
se ao conhecimento histórico sobre o meio, que se via em fase de mutação "genética" ou de "extinção" (Freire Filho, 2007, p.116). Esse quadro de pesquisas sobre a TV pode ser averiguado em vários países europeus, sobremaneira na França e na Grã-Bretanha, e do outro lado do Atlântico, notadamente nos Estados Unidos.

Na França, os estudos históricos sobre a TV ganhavam espessura historiográfica. Seu avanço ocorreu com base na factível e real interdisciplinaridade. Historiadores e pesquisadores da área de Comunicação e das Ciências Sociais passaram a traçar objetivos e estudos conjuntos. Com a abertura, em 1998, do arquivo de audiovisuais da televisão francesa, arquivados na Inatéque de France (Institut National de l'Audiovisuel - INA), instalada na nova Biblioteca Nacional da França, denominada François Mitterrand, a produção televisiva era promovida ao padrão da escrita e reconhecida como um dos modos maiores da expressão contemporânea. Assim, o audiovisual televisivo ia conquistando entre os franceses a posição de objeto de conservação, o que equivale a dizer que passava a ser reconhecido como parte da memória coletiva da França contemporânea. A dimensão do material televisivo arquivado e acessível impunha ao pesquisador da TV certificar-se de métodos e conceitos apropriados e concatenados às perspectivas de abordagem histórica.

Dentro desse quadro, o historiador Jérôme Bourdon e o semiólogo François Jost sugerem, na introdução do livro organizado por ambos, uma fértil e inicial orientação aos pesquisadores do meio: "é necessário não perder de vista que a TV é um fenômeno plural, simultaneamente, nos múltiplos modos em que é abordado e nas diferentes formas de televisão que existem diacrônica e sincronicamente em que possam oferecer-se para a análise" (Bourdon \& Jost,1998, p.6). Orientação bastante fértil, pois coloca em suspeição boa parte das teorias sobre a TV, as quais se apresentam repletas de assertivas unidimensionais e unidirecionais, taxonomias ahistóricas e, por vezes, prejulgamentos sobre quase tudo o que diz respeito ao universo televisivo, além de elas não reconhecerem o meio como portador de uma cultura própria. 
Na direção aberta por Bourdon e Jost começavam a emergir na França os estudos sobre a variedade de programas - gêneros e subgêneros, bem como suas inter-relações. As imagens televisivas passam a ser objeto e fonte de pesquisas. Enfim, o material audiovisual produzido pela televisão é visto e analisado sob a perspectiva histórica e, o mais importante, os estudos sobre a recepção televisiva redimensionam-se com base em abordagens históricas. Entretanto, tal perspectiva não tem sido ainda amplamente aplicada no âmbito dos estudos de comunicação franceses sobre a TV. Mas tem prosperado.

$\mathrm{Na}$ Grã-Bretanha, estudiosos da televisão ligados à área de Comunicação - com destaque para John Corner (1991; 2003) - investem significativamente na perspectiva de abordagem histórica da televisão britânica, ampliando o estudo da produção televisiva. Esses estudos reúnem relatos detalhados de mudanças na técnica e na estética, na linguagem do teledrama e do entretenimento televisivos, com elucidações das estruturas institucionais, dos desenvolvimentos tecnológicos e do quadro histórico sociocultural e artístico. Embora fosse a massa de audiovisuais produzidos e arquivados pela BBC a mais consultada e focalizada de início, rapidamente, e dentro do possível, os pesquisadores da Comunicação passam a tratar também do material televisivo das emissoras privadas britânicas.

Assim, o quadro atual dos estudos históricos sobre a TV parece ter efetivado parte do intuito pioneiro de Briggs e Jeanneney, qual seja: trazer a televisão para a área da História e levar a História para o interior dos estudos da TV desenvolvidos na área de Comunicação. Efetivação parcial em razão de os estudos históricos sobre a televisão e sua programação avançarem mais significativamente na área de Comunicação do que no âmbito historiográfico, e parcial também porque a perspectiva histórica dos estudos da TV na área de Comunicação não tem sido ainda tão amplamente realizada.

No Brasil, a história da história da televisão é outra. Apesar de englobar muito dos expedientes do desligamento da História com relação à TV, a historiografia sobre a contemporaneidade brasileira não conta com nenhum congênere aos moldes de Briggs ou Jean- 
neney. Nem mesmo a centralidade que a televisão tem ocupado na vida nacional e a existência paradoxal da Rede Globo de Televisão caso citado ou mencionado com frequência na literatura estrangeira ocupada com a televisão de maneira geral - foram ainda suficientes para despertar o interesse dos historiadores brasileiros para o estudo do meio.

A história da TV brasileira tem sido tratada, geralmente, por alguns poucos pesquisadores ligados à área de Comunicação, notadamente a partir dos anos 1980. Suas pesquisas, em regra, estão centradas na dimensão institucional e apresentam uma trajetória linear do meio. E são meramente nomeadas como interdisciplinares. Apesar de serem elaborados sob pressupostos teóricos da Sociologia, acabam por privilegiar - a título de perspectiva analítica e periodização - a influência, direta ou indireta, do poder político (na forma democrática, mas sobremaneira no período do regime militar) e do poder do capital (nacional ou estrangeiro, este notadamente norte-americano) na estruturação e no desenvolvimento do serviço de televisão e de suas organizações.

O quadro de referência causal e explanatório da bibliografia ocupada com a história da TV brasileira (Como se formou a televisão brasileira? Quando ela mudou? Em que aspectos a TV foi modificada? Quais os móveis dessa mudança?) e seu quadro analítico (Quais as influências dessas mudanças na vida social e política? Quais os móveis da mudança interessavam ou favoreceram a quais grupos?) têm sido calcados em questões atreladas à teoria da dependência, ao imperialismo e homogeneização cultural, a projetos de governos desenvolvimentistas, nacionalistas ou neoliberais, ao processo de modernização autoritária, à difusão e ao reforço da ideologia dominante, à publicidade de produtos e propagação de estilos de vida (Freire Filho, 2007, p.123-4).

Como expoentes desta vertente de pesquisa, Freire Filho (idem) destaca, de maneira precisa e acertada, os trabalhos de Sergio Caparelli (1982), Sergio Matos (1990; 2002) e Othon Jambeiro (2001). À lista devem ser acrescidos, entretanto, os trabalhos de autoria de Cesar Bolaño (1989; 1999) e mesmo o manual de Inimá Simões (2004). 
Se não é possível afirmar categoricamente que nenhum historiador brasileiro tenha se ocupado da história da TV e que não haja historiadores brasileiros que não utilizaram a produção televisiva como fonte em suas pesquisas, é lícito asseverar que vários fatos e processos do campo televisivo e de suas relações com a sociedade brasileira não encontraram ressonância na pauta da pesquisa histórica ocupada com o Brasil contemporâneo. Dessa maneira, a historiografia brasileira encontra-se alheada das discussões e ações envolvidas com a democratização da TV brasileira, debates e práticas avolumados a partir dos trabalhos da Assembleia Constituinte em 1987/1988, reforçados durante o período de adoção de medidas do governo FHC para o setor e redimensionado com a definição do sistema da TV digital tocado pelo primeiro governo Lula, assim como pela criação de uma rede de televisão pública implantada durante seu segundo mandato presidencial. Fatos e processos que melhor poderiam ser compreendidos, explicados e analisados pela pesquisa histórica sobre a comunicação social eletrônica brasileira e suas relações com os demais domínios sociais da vida nacional, cujas principais propostas e dinâmicas remontam pelo menos aos anos 1930 .

Na mesma situação encontra-se a historiografia brasileira em relação aos processos de alterações na produção, difusão e recepção da programação televisiva decorridas desde a década de 1990 - as quais têm sido, inclusive, tachadas por muitos críticos como aceleradoras da degeneração do senso histórico e da memória individual e coletiva. Assim, parte importante e crucial das práticas e representações socioculturais encetadas no cotidiano da vida nacional contemporânea, em muito fomentadas ou criadas via produtos televisivos, carece da compreensão e da explicação dos pesquisadores brasileiros formados e atuantes na seara de Clio.

\section{Para plugar a TV à História}

O historiador que se lançar ao estudo da televisão se confrontará com um problema enfrentado pelos demais pesquisadores que se 
ocupam com o meio, qual seja: a definição do objeto de pesquisa. A TV tem sido definida como um meio "complexo", "elusivo", "colossal", "caótico", "híbrido" e até mesmo como "desafiante" no âmbito dos analistas da TV. E a natureza ambígua, polimorfa da TV tem refletido, como bem caracterizou John Corner, nas pesquisas ocupadas com a história do meio, quer entre pesquisadores da Comunicação, quer entre os poucos historiadores que se lançaram nessa tarefa. Segundo Corner (2003, p.275-6), é possível identificar pelo menos cinco aspectos diferentes da televisão, cada qual merecedor da atenção dos ocupados com a história do meio:

- a televisão como instituição, como indústria e suas organizações, enquadrada pela política e pela gestão empresarial;

- a televisão como produtora, cujo foco recai sobre a cultura profissional e a prática profissional, constante nos escritos autobiográficos ou de memória de profissionais da TV;

- a televisão como representação e forma, um enquadramento estético retirado do vocabulário da crítica de artes, particularmente a do teatro e a do cinema (crescente linha de trabalho nos estudos históricos da TV, sobremaneira ocupado com a análise do teledrama, porém minado por problemas de acesso ao material audiovisual, como mencionarei mais adiante, sobremodo em relação ao acervo televisivo brasileiro);

- a televisão como fenômeno sociocultural, profundamente interconectado com a alta política, com as inconstantes circunstâncias da esfera pública e a sociedade civil, com a cultura popular e o caráter variável do lar e dos valores domésticos como salienta Corner, este se caracteriza como um dos mais difíceis aspectos a serem seguidos pelo pesquisador, porém, pode-se acrescentar, talvez seja o mais instigante e fértil para o conhecimento e a compreensão da TV no cotidiano social e cultural;

- a televisão como tecnologia, um experimento científico que, ao mesmo tempo, se tornou um item doméstico e um recurso crescentemente poderoso à mudança na estética social, aspecto bastante abandonado pelos estudos históricos sobre a 
$\mathrm{TV}$, sendo mais frequentemente focalizado pela história da Engenharia (no Brasil, as poucas pesquisas dessa natureza são realizadas por historiadores da Ciência e Tecnologia).

Ademais, Corner (2003, p.276) assevera acertadamente que, ainda que o historiador da TV possa apresentar um significativo conteúdo ao se dedicar somente a uma das cinco dimensões acima citadas, a mais fértil pesquisa histórica sobre a TV será aquela que conseguir pautar-se pela interconexão histórica entre vários aspectos do meio. Não se trata, portanto, da demanda por uma história total da televisão.

Em termos da sociologia da prática de Pierre Bourdieu (1996; 1997) e da história cultural de Roger Chartier (1990), pode-se pensar em um estudo histórico da TV envolvendo a compreensão, ao mesmo tempo, de seu aparato de funcionamento (em termos tecnológicos, organizacionais e regulatórios) e das práticas e representações dos agentes integrados ao campo televisivo, tanto em termos de relações internas desse campo quanto nas relações mantidas com outros domínios sociais específicos que compõem a sociedade, uma história da TV calcada na busca por conhecer e entender feixes do conjunto de relações que geraram um campo de possibilidades históricas a processos de manutenção e mudança do meio. Tal alternativa serve para evitar cair na armadilha estéril do pensamento essencialista e buscar entender historicamente a televisão e os seus produtos - assim como os demais espaços, práticas e bens do campo cultural - dentro da perspectiva relacional, a qual somente é possível se o historiador sempre tiver em mente a pluralidade de relações sociais encetadas no interior do mundo televisivo e as do mundo social, político, econômico e cultural que pesam na estrutura e dinâmica do meio, sempre dentro da relação tempo e espaço.

Se no campo teórico, evidentemente, o historiador ocupado com o estudo da televisão encontrará várias alternativas de análise além da que destaquei acima, todos os historiadores terão de enfrentar uma mesma chaga com relação à pesquisa sobre a televisão, a saber: a parcialidade das fontes e o difícil acesso a elas. 
Cabe aqui a observação muito precisa formulada por Corner a respeito da documentação para a pesquisa histórica sobre a TV. Para o historiador da TV, a pergunta inicial e comum a toda pesquisa histórica - o quanto olhar e qual detalhe ater-se? - é geralmente eclipsada pela indagação: o que há para olhar? (Corner,2003, p.277), situação não apenas imposta aos pesquisadores britânicos, com mais facilidade de acesso e com a existência do acervo audiovisual da BBC, mas também aos franceses, apesar da invejável organização do acervo televisivo pelo INA.

Isto se deve ao fato de a "pré-história" da televisão ter se desenvolvido com base em programas emitidos ao vivo, portanto, sem deixar registros audiovisuais. E mesmo quando da inclusão do videotape - a partir da segunda metade da década de 1950 nos EUA e em parte da Europa, e no Brasil a partir dos anos 1960 - era comum, e ainda mais intenso na televisão brasileira, o expediente de reutilizar-se as fitas já gravadas para registros de outros conteúdos, ao qual se somava muitas vezes, dependendo do país, o descuido no arquivamento do material gravado, levando à deterioração de grande parte deste, ou mesmo o descarte puro e simples das fitas gravadas. A televisão brasileira figura com uma das grandes atrizes nesse programa. Assim, a ausência do registro audiovisual é uma limitação para qualquer pesquisa que procure analisar historicamente os estilos e as formas da programação do início da TV, ou mesmo de estágios mais avançados da história do meio.

Com a predominância do modelo privado de televisão no Brasil, grande parte do que se produziu e continua a ser produzido em matéria de audiovisual televisivo deve-se à iniciativa privada. Ademais, o caráter de serviço público das emissoras de televisão não apenas não é central em suas grades de programação como também não é extensivo ao acesso público de seus arquivos audiovisuais, situação que acresce ainda mais problemas ao desempenho da pesquisa histórica sobre a TV, e que, por vezes, somente é facilmente contornada por aqueles que desfrutam de trânsito nas emissoras, quer como profissionais, quer como amigos destes. 
A Rede Globo de Televisão, dispondo do mais significativo e bem organizado arquivo de audiovisual, tem criado uma sorte de empecilhos ao acesso ao seu acervo, depositado no Cedoc, notadamente por conta de seu projeto Memória Globo - materializado em publicações relacionadas com a trajetória da emissora e a formação de seu site memoriaglobo.com - e de sua estratégia de venda de sua produção no modelo DVD, expedientes iniciados em 1999. Outras emissoras particulares - como a Record, o SBT e a Bandeirantes impõem obstáculos ao acesso de seus arquivos audiovisuais que beiram o surreal.

O historiador poderá contar com o acervo audiovisual da TV Cultura de São Paulo, emissora pública cujo arquivo é bem organizado - inclusive com processos avançados de digitalização de seu material - e de acesso relativamente mais fácil quando comparado ao das emissoras privadas. Contudo, a TV Cultura, como já ressaltou Laurindo Lalo Leal (1988), é uma emissora mais lida do que vista, dado que sua programação é muito mais objeto de matérias jornalísticas do que assistida pela população em geral. Assim, se, de um lado, o estudo histórico da emissora é de crucial importância para o entendimento das possibilidades e dos obstáculos à existência e atuação do modelo público de TV no Brasil, de outro, a análise de sua programação atende muito pontualmente às pesquisas envolvidas com questões sobre a relação entre produção televisiva e a sociedade brasileira contemporânea.

O que restou da produção televisiva de emissoras pioneiras e há muito extintas, além do risco eminente de ser perdido definitivamente por questões de conservação, não se encontra disponível à consulta pública:

- por conta da sinistra apropriação do acervo por outra emissora em atividade, como é o caso de material produzido pela TV Excelsior de São Paulo que se encontra nas dependências da TV Gazeta;

- pelo fato de a produção ter sido doada à instituição pública, mas que ainda carece de processos amplos de recuperação, si- 
tuação de parte da produção audiovisual da TV Tupi paulista que se encontra depositado na Cinemateca de São Paulo;

- de casos inusitados, como cerca de cem rolos de videotape da programação da TV Excelsior paulista sob a guarda da TV Cultura de São Paulo em razão do desconhecimento de sua origem e de a quem realmente pertence, ou pertenceria, e necessitando de processo de recuperação adequado;

- e, por fim, um quadro pouco mais auspicioso, pois parte da produção da TV Tupi carioca foi encontrada por coincidência em antigo prédio de propriedade dos Diários Associados e doado ao Arquivo Nacional, o qual firmou contrato com a Rede Globo para recuperação e posterior depósito na instituição pública, porém não antes do direito de a emissora de TV da família Marinho utilizá-lo por um ano.

Mesmo vencidos os obstáculos de acesso, o historiador deverá ter toda a cautela com o material a ser consultado, posto que ele deverá ter sempre em mente que o que foi arquivado não é necessariamente aquilo que foi ao ar, notadamente no caso das edições de telejornais. A existência de uma gravação da emissora, por mais confiável que seja, não é garantia de que aquele documento que se encontra no arquivo da emissora foi transmitido exatamente daquele modo. Diante do material televisivo arquivado nas emissoras, a noção de reprodutibilidade técnica da história fornecida por Walter Benjamin deve ser uma companheira do pesquisador, como bem alertou recentemente Eugênio Bucci (2004).

Assim, torna-se necessário o confronto do material audiovisual com a documentação relacionada à produção e veiculação do audiovisual da emissora, documentos impressos e geralmente acompanhados de anotações manuscritas, como scripts, pautas da edição do telejornal, memorandos internos. De maneira indireta, é apropriado confrontá-lo com o material que a imprensa impressa divulgou ou fez notar sobre o conteúdo levado ao ar, podendo-se encontrar vestígios deste expediente desde os cadernos de política, passando pelo de economia, até o de cultura, o qual tem aberto, ao longo das 
décadas, cada vez mais espaço ao tratamento jornalístico do mundo televisivo. Ademais, pode-se contar com a memória de agentes atuantes na produção televisiva, seja por meio da análise sistemática da literatura de memória, seja por meio de precisas e aprofundadas técnicas da história oral.

As fotografias relativas à programação televisiva também são uma boa fonte para se remontar ou analisar a história do meio e sua programação, sobremaneira em relação às primeiras décadas de operação da TV brasileira. Material que pode ser encontrado tanto em mãos de antigos profissionais do setor quanto em material comemorativo publicado pelas emissoras e por jornais e revistas, ainda que em ambos os casos apresentem-se fragmentadas. São imagens paradas, mas elas têm o potencial de colocar em movimento e, por vezes, até acelerar os estudos históricos da produção televisiva. Basta munir-se de acuradas técnicas de análise da fotografia e ter conhecimento aprofundado da história da televisão brasileira, quer sobre seus agentes e técnicas, quer sobre a estrutura e a dinâmica do universo televisivo nacional.

Portanto, não é apenas o conteúdo audiovisual e a forma do programa que deverão contar para a pesquisa do historiador da televisão, mas todo o entorno da produção e da divulgação dos programas televisivos, sem se esquecer, quando possível, da esfera da recepção.

A história da TV não engloba, todavia, apenas a descoberta de documentos próprios do meio, mas pode cuidar das práticas e representações que criaram as possibilidades sociais, culturais e políticas para o funcionamento da TV - quer de maneira geral, quer no caso de emissora em particular -, remontando e explicando historicamente discursos, imaginários, debates, projetos, ações, representações e consumos encetados com relação ao mundo televisivo, seus produtos, suas formas de divulgação e sua recepção. Nesta direção, o material da imprensa impressa, tanto o da mais geral quanto o da especializada sobre o meio, a literatura, o teatro contemporâneo, filmes, o debate das casas legislativas registrados em atas ou anais de suas sessões, as sondagens da opinião pública, memórias e autobiografias, servem, cada qual segundo a sua lógica de produção e 
mediante questões formuladas pelo historiador, como um fértil manancial de fontes para se conhecer e precisar sócio-historicamente as práticas e representações relacionadas à televisão.

É importante também que o historiador busque conhecer as propagandas que foram veiculadas nos intervalos comerciais do programas que pretende analisar. Além de seu aspecto comercial evidente, a propaganda funciona, muitas vezes, como um contraponto ou uma complementação ao telespectador sobre visões e noções que os programas televisivos possam emitir sobre fatos, temas e ideias. Não por acaso os departamentos de empresas privadas e instituições públicas costumam decidir exatamente em que momento e bloco de publicidade querem suas propagandas veiculadas.

No presente imediato, e diante deste quadro, o historiador que queira "fugir" às dificuldades e aos impedimentos relacionados a arquivos do material televisivo conta com duas alternativas, porém parciais e fragmentadas. São elas: DVDs contendo material televisivo e que são vendidos no mercado; e sites de compartilhamento de vídeos, com destaque para o maior deles, o YouTube.

No caso dos DVDs, o historiador poderá trabalhar com material como: seriados e desenhos animados estrangeiros, tanto os exibidos entre as décadas de 1960 a 1980 quanto os mais recentes; e um conjunto variados de programas veiculados pela Rede Globo de Televisão, tendo como carro-chefe as telesséries (várias de fundo histórico ou baseada em obras da literatura brasileira ou portuguesa). Pode-se contar com DVDs que reproduzem algumas edições de programas humorísticos (TV Pirata, Chico Anísio), jornalísticos (Jornal Nacional, Globo Rural), de revista eletrônica (Fantástico) e programas infantis (Sítio do Pica-Pau Amarelo, agora também com a versão levada ao ar nos anos 1970), embora estes tenham o inconveniente de ser fruto de seleções prévias, expediente que acaba por não contemplar uma seriação completa do programa focalizado, além de, por vezes, servir apenas para ressaltar os supostos qualificativos dele.

Não por acaso já há dissertações e teses da área de Comunicação que têm tomado as minisséries da Rede Globo como objeto de estudo. Contudo, os DVDs, mesmo trazendo extras, não são suficientes 
para uma análise mais aprofundada das práticas e expedientes envolvidos com a produção e a veiculação do material, necessária para uma compreensão histórica do processo de produção dos programas televisivos focalizados. Daí, talvez, as perspectivas de análise do material televisivo na mídia DVD restrinjam-se a leituras ou interpretações dos códigos internos do programa, deixando, portanto, de tomá-lo com base em uma análise histórica e dentro de uma perspectiva relacional, ou seja, focando o campo de possibilidades da realização da minissérie gerados com base em relações sociais internas à emissora e as dela com o universo televisivo como um todo e com os demais domínios sociais que compõem a sociedade.

$\mathrm{O}$ acervo do YouTube não deve ser desprezado pelo historiador da TV. Basta citar que ele é enormemente superior ao que o pesquisador poderá encontrar, por exemplo, no Museu da Imagem e do Som, tanto no do Rio de Janeiro quanto no de São Paulo, instituição renomada que, curiosamente, abriga uma quantidade risível sobre a produção televisiva, quer a dos primórdios do meio no Brasil, quer a da fase em que a televisão já tinha invadido os lares brasileiros, notadamente a partir dos anos 1970.

Claro que o acervo do YouTube em termos de audiovisuais da TV brasileira não é igual ao que se manteve da produção televisiva nacional, bem como se apresenta de forma bastante fragmentada. Não tem a estatura e substância do material produzido pela extinta TV Tupi, mas é no YouTube que o historiador pode encontrar e acessar facilmente muitos fragmentos da programação daquela emissora, dentre os quais poderá garimpar pepitas que podem servir para melhor perceber a história da emissora e da TV brasileira em geral, além de encontrar no material televisivo veiculado no site fontes para a pesquisa sobre outros temas da contemporaneidade. De igual modo, é no YouTube que se podem encontrar fragmentos da extinta TV Excelsior, embora o material disponível desta emissora encontre-se em menor número e ainda mais fragmentado. Não é diferente o caso do material da também extinta TV Manchete.

Cito primeiro a situação do material de emissoras de TV extintas veiculado no YouTube justamente para caracterizar o papel de 
arquivo ou museu que esse site de compartilhamento tem desenvolvido no âmbito da produção televisiva, classificação que não é exagerada frente ao descaso do poder público brasileiro com relação a projetos de formação de arquivos especializados na produção de TV, ou mesmo à falta de empenho dele para definir e estabelecer regras de acesso ao arquivo das emissoras atuantes, esquecendo-se, assim, que elas somente operam em decorrência de concessão pública.

Ao papel de arquivo atribuído ao YouTube soma-se mais um, talvez o mais importante simbolicamente, qual seja: a potencialidade do site como meio para provocar a inflexão no quadro de impossibilidades e dificuldades de acesso aos arquivos televisivos segundo imposições de redes de TV em atuação. Ao disponibilizar o material das emissoras atuantes - tanto o veiculado no passado como o veiculado no presente, e ainda que fragmentados -, o YouTube promove uma tensão no poder - quase inconteste - dos concessionários em dificultar ou mesmo impedir o acesso aos arquivos de audiovisuais produzidos por suas emissoras, ainda que as pressões das emissora e dos autores dos audiovisuais sejam intensas e tenham provocado a retirada de parte do material até há pouco disponibilizado.

Sem se esquecer que a disponibilização do material televisivo no YouTube corrobora para que a memória que as emissoras atuantes procuram firmar sobre sua atuação na vida nacional possam ser confrontadas. Basta pensar no famoso caso da edição do debate final entre os então candidatos Collor e Lula exibida pelo Jornal Nacional, da Rede Globo, às vésperas do dia da votação do segundo turno para presidente da República em 1989. O projeto Memória Globo procura explicar e minimizar o fato, como pode ser visto tanto no livro JN - 35 anos (2004) como no site memoriaglobo.com, recém-lançado. No site está disponibilizada apenas a edição do telejornal Hoje do dia seguinte ao debate, dado que a emissora alega não dispor de registro da edição do Jornal Nacional daquele dia, e que mesmo a do Hoje teria sido obtida de cópia da gravação realizada por um telespectador. Ainda segundo informação do site, as duas versões foram questionadas. A do telejornal Hoje por mostrar um equilíbrio que não houve no debate; a do Jornal Nacional por 
favorecer a participação do candidato Collor, visões que provariam que a Rede Globo teria se mantido neutra e objetiva quando do tratamento jornalístico daquele debate.

Mas é no YouTube que qualquer internauta pode acessar, fácil e livremente, amplos e significativos trechos do debate Collor e Lula - afinal o debate também é um produto televisivo - e confrontar com o que diz e o que é apresentado pelo site memoriaglobo.com. Sem se esquecer que é também no YouTube que se podem acessar outros trechos de como a Rede Globo promoveu em sua programação a figura política de Collor, até mesmo com inusitada participação do outrora "caçador de marajás" no popular programa do Chacrinha, então levado ao ar nas tardes de sábado e assistido por milhões de telespectadores.

Em tempo, a maior parte dos vídeos do YouTube com programas televisivos foram realizados com gravações em televisores domésticos, portanto são vídeos de edições que foram ao ar, e muitas são acompanhadas de intervalos comerciais. Para alterar esse quadro, os historiadores devem, antes, incluir a produção televisiva no rol de seus objetos e fontes de pesquisa e, associados a pesquisadores de outras áreas interessados nos estudos históricos da TV brasileira, empenhar-se para a criação de arquivos públicos dedicados à produção televisiva ou, ao menos e no momento, pelo estabelecimento de regras de acesso aos arquivos das emissoras atuantes, promovendo assim o compartilhamento democrático do controle remoto da história da TV brasileira e da atuação do meio na vida nacional contemporânea - instrumento que continua empunhado, infelizmente, tão somente pelos concessionários das redes de televisão.

\section{Referências bibliográficas}

BOLAÑO, C. R.S. Indústria cultural, televisão e estratégia de programação em três países da América Latina: Brasil, Argentina e Uruguai. In: KUNSCH, M. M. K.; FERNANDES, F. A. M. Comunicação, democracia e cultura. São Paulo: Loyola, 1989. 
A economia política da televisão brasileira. In: Revista Brasileira de Ciências da Comunicação, 22(2), jul./dez. 1999, p.35-52.

BOURDIEU, P. As regras da arte. São Paulo: Companhia das Letras, 1996. Sobre a televisão. Rio de Janeiro: Jorge Zahar Editores, 1997.

BOURDON, J.; JOST, F. (Eds.). Penser la télévison. Paris: INA/Nathan, 1998, p.6-11.

BRIGGS, A. The history of broadcasting in United Kingdon. Birth of broadcasting. Oxford: Oxford University Press, 1961.

The history of broadcasting in United Kingdon. Golden Age of Wireless. Oxford: Oxford University Press, 1965.

The history of broadcasting in United Kingdon. War of words. Oxford: Oxford University Press, 1970.

The history of broadcasting in United Kingdon. Sound and vision. Oxford: Oxford University Press, 1979.

The history of broadcasting in United Kingdon. Competition. Oxford: Oxford University Press, 1995.

Problems and possibilites in the writing of broadcasting history. in: $\quad$ The collected essays of Asa Briggs. Serious pursuits: communications and education. v.3. Illinois: Illinois University Press, 1991, p.114-8.

BUCCI, E. A história na era de sua reprodutibilidade técnica. In:

KEHL, M. R. Videologias. São Paulo: Boitempo, 2004, p.192-219.

CAPARELLI, S. Televisão e capitalismo no Brasil. Porto Alege: L\&PM, 1982.

CHARTIER, R. A história cultural: entre práticas e representações. Rio de Janeiro: Bertrand Brasil, 1990.

CORNER, J. (Ed.). Popular television in Britain: essays in cultural history. Oxford: Clarendon Press, 1999.

Fiding data, reading patterns, telling stories: issues in the historiography of television. In: Média, Culture E Society, 25(2), 2003, p.273-80. ECO, U. TV: la transparencia perdida. In: __ La estratégia de la ilusión. Barcelona: Lumem, 1986, p.200-23.

FREIRE FILHO, J. Escrevendo a história cultural da TV no Brasil: questões teóricas e metodológicas. In: RIBEIRO, A. P. G.; FERNANDES, L. M. A. Mídia e memória: a produção de sentidos nos meios de comunicação. Rio de Janeiro: Mauad X, 2007, p.115-35.

GILDER, G. A vida após a televisão. Rio de Janeiro: Ediouro, 1996.

JAMBEIRO, O. A TV no Brasil do século XX. Salvador: EDUFBA, 2002. JEANNENEY, J.-N. et al. Télévision, novelle mémoire. Paris: Le Seuil/ INA, 1982. 
Uma história da comunicação social. Lisboa: Terramar, 1996, p.221-62.

LEAL FILHO, L. Atrás das câmeras: relações entre cultura, Estado e televisão. São Paulo, Summus, 1998.

MATOS, S. Um perfil da TV brasileira. Salvador: A tarde, 1990.

História da televisão brasileira: uma visão econômica, social e política. Petrópolis; Vozes, 2002.

MISSIKA, J.-L. La fin de la télévision. Paris: Éditions Du Seuil/La répuplique dês Idées, 2006.

SIMÕES, I. A nossa TV brasileira: por um controle social da televisão. São Paulo: Editora Senac, 2004. 



\section{Parte III}

\section{PROCESSO POLÍTICO E RELAÇÕES INTERnACIONAIS NO CONE SUl}





\section{7 \\ Brasil e Argentina: uma anÁlise COMPARATIVA DAS POLÍTICAS ECONÔMICAS No CONTEXTO dA GRANDE Depressão DOS ANOS 1930}

Francisco Luiz Corsi ${ }^{1}$

O período entre 1930 e 1945 foi um divisor de águas para as economias argentina e brasileira, que deram passos importantes para romperem com seu passado agrário-exportador e redirecionarem o desenvolvimento no sentido de economias urbano-industriais. As políticas econômicas adotadas nesse período condicionaram o desenvolvimento de ambas as economias nas décadas seguintes. O objetivo do presente texto é discutir as diferentes estratégias do Brasil e da Argentina para enfrentar a Depressão da década de 1930 e o quadro internacional que emergiu com a Segunda Guerra Mundial.

\section{As diferentes respostas à crise de 1929}

A crise de 1929 abriu uma fase de profunda crise na economia mundial e provocou grandes transformações com múltiplos im-

1 Doutor em economia e professor da Unesp - Marília, é autor de Estado Novo: política externa e projeto nacional. São Paulo: Editora Unesp, 2000 e coeditor de Dimensões da crise do capitalismo global. Brasil e a crise da mundialização do capital. Londrina: Práxis, 2009. 
pactos em sua periferia. Novas possibilidades de desenvolvimento foram abertas para aqueles países que já tinham alcançado certo patamar de desenvolvimento econômico. Essas novas possibilidades decorreram, em grande parte, da relativa desarticulação da economia mundial, fruto da crise estrutural do capitalismo. Nesse contexto, definiram-se projetos nacionais de desenvolvimento, visando à industrialização e à autonomia nacional, como, por exemplo, os projetos de Vargas e Perón.

A depressão que seguiu a debacle da Bolsa de Valores de Nova Iorque atingiu em cheio a Argentina e o Brasil, encerrando uma fase no desenvolvimento desses países. O PIB argentino, entre 1929 e 1932 , caiu $13,8 \%$, sendo de $17,8 \%$ a retração do setor industrial e de $8,5 \%$ a do agrícola. O crescimento foi retomado em 1934. No ano seguinte, o PIB ultrapassaria o de 1929. No Brasil, a crise, embora grave, foi aparentemente menos profunda. O PIB retrocedeu 4,5\% em 1930, e no ano seguinte, 3,3\%. A economia brasileira voltaria a crescer um pouco antes da economia argentina, em 1933, puxada pelo setor industrial. Ambos os países sofreram com a queda dos preços dos produtos primários, com a fuga de capitais e com a quase total interrupção dos fluxos internacionais de capitais, o que acarretou forte desvalorização de suas respectivas moedas, além de crises cambiais (Abreu, 1992; Cano, 2000).

A vida política argentina e brasileira não passaria incólume pela crise, embora não se possa estabelecer uma relação simplista entre tais mudanças e a crise internacional. Hipólito Yrigoyem, eleito pela União Cívica Radical, foi deposto, em setembro de 1930, por um golpe de Estado. A queda de Yrigoyem sugere a enorme força do setor agropecuário voltado para as exportações e aliado ao capital estrangeiro, em particular ao britânico, que formava o bloco hegemônico defensor do Estado Liberal e da inserção da Argentina como produtora de bens primários na economia mundial (Etulain, 1991). ${ }^{2}$

2 Em 1929, as exportações argentinas consistiam, fundamentalmente, de bens agroindustriais, e 70\% da produção agropecuária da região do Pampa destinavam-se às exportações (Cano, 2000, p.93). 
A Revolução de 1930 abriu novas possibilidades de mudanças estruturais e de desenvolvimento para o Brasil ao deslocar a oligarquia cafeeira da posição hegemônica e ao abrir uma crise de hegemonia na qual nenhum setor dominante tinha condições de firmar sua proeminência (Fausto, 1988; Draibe, 1985). Os anos iniciais da década de 1930 foram de grande instabilidade política e econômica, com diferentes projetos em luta. Não estava decidido ainda por quais caminhos seguiria a economia brasileira. A vitória do projeto de Vargas, configurada na instauração do Estado Novo, não estava inscrita na revolução (Pandolfi, 1999). Mesmo esse projeto era algo não muito definido nesse momento (Corsi, 2000). Na Argentina, o controle do poder pelos grandes proprietários fechou o leque de opções de encaminhamento da crise. Os governos de José F. Uriburo e Augustín P. Justo continuaram aplicando, pelo menos inicialmente, políticas mais tímidas no enfretamento da crise; o Brasil, por sua vez, passou paulatinamente a adotar uma política de enfrentamento da crise e depois um nítido programa de desenvolvimento.

Nos primeiros meses de governo, Getúlio Vargas adotou uma política econômica de caráter ortodoxo no enfrentamento da crise. O agravamento da situação econômica do país, entretanto, o obrigaria a mudar de rumo e a implementar medidas voltadas para a sustentação da atividade econômica. De fundamental importância foi, como é amplamente conhecido, a nova política de defesa do café, que passou a basear-se, sobretudo, na ampliação do crédito interno para a compra de parte do excedente de produção. Os recorrentes déficits públicos, em particular o de 1932, a política de expansão do crédito e a larga emissão de moeda também foram decisivos para a relativamente rápida recuperação da economia brasileira, que voltou a crescer com base nas atividades voltadas para o mercado interno, particularmente no setor industrial. Tanto os déficits quanto a expansão na base monetária não estavam nos planos do governo, deveram-se, sobretudo, à revolta de 1932 em São Paulo e à severa seca no Nordeste. A sustentação da atividade econômica associada à desvalorização da moeda e ao controle das operações 
cambiais, introduzido em 1931, contribuiu para a criação de condições favoráveis ao desenvolvimento industrial, que se sustentou na indústria existente, que tinha passado, na década anterior, por um processo de relativa diversificação. No entanto, a política econômica adotada no período, como assevera Furtado (1982), não visava intencionalmente fomentar a indústria, mas sim buscar responder aos graves problemas colocados pela crise internacional (Furtado, 1982; Cano, 2000).

Todavia, algumas medidas aplicadas no período já indicavam uma mudança de postura no encaminhamento das questões econômicas e alterações na estratégia de desenvolvimento. Ao lado da centralização das decisões políticas e econômicas no âmbito do governo federal, cabe destacar, pela sua importância e abrangência, a introdução da legislação trabalhista, a criação dos sindicatos corporativos e a criação do Ministério do Trabalho, Indústria e Comércio a partir de 1930. Cabe também destacar: 1. a criação de órgãos de regulação e fomento de setores específicos, como, por exemplo, o Instituto do Açúcar e do Álcool, o Conselho Federal de Comércio Exterior, o Departamento de Produção Mineral etc; 2. o chamado reajustamento econômico, que perdoou $50 \%$ das dívidas dos proprietários rurais contraídas até 30 de junho de 1933; 3. a reforma tarifária de 1934, de cunho protecionista; 4. a proibição de importação de máquinas e equipamentos para os setores da indústria considerados em "superprodução" e a isenção de tarifas sobre importações de equipamentos para alguns setores industriais considerados importantes; 5. a reforma educacional, em particular o incentivo ao desenvolvimento de cursos técnicos (Corsi, 2000).

A política econômica implementada entre 1930 e 1937 dificilmente pode, contudo, ser considerada uma nítida manifestação de um projeto de desenvolvimento centrado na indústria. Os indícios relativos à busca de novos rumos para a economia brasileira são robustos, mas o projeto industrializante não estava maduro ainda. O projeto industrializante amadureceria ao longo do Estado Novo, 
quando se esboçou um projeto de desenvolvimento nacional (ibidem). ${ }^{3}$

$\mathrm{Na}$ Argentina, o poder continuou nas mãos dos setores conservadores ligados às exportações. Dessa forma, a política de enfretamento da crise parece ter sido fortemente condicionada pela reafirmação do predomínio dos grandes proprietários de terras, expresso no golpe de Estado que colocou Uriburo no poder e depois nas eleições de Justo. O Brasil, ao contrário, vivia uma crise de hegemonia, que abria uma maior possibilidade de adoção de políticas alternativas. No país platino não se observa, pelo menos nos primeiros anos da crise, medidas de caráter industrializante e nem um programa amplo de defesa da renda e do emprego semelhante à política de defesa do café implementada por Vargas. A suspensão da convertibilidade da moeda ainda em 1929, o que no Brasil só viria a ocorrer em dezembro de 1930, quando as nossas reservas tinham se esgotado, não impediu a forte desvalorização do peso. Como no Brasil, foram introduzidos, em 1931, controles de câmbio, que seriam aperfeiçoados em 1933 com a introdução de licenças de importações e taxas múltiplas de câmbio, pois a deterioração das contas externas não deixava alternativa. Essas medidas adotadas a partir de 1933 estimulariam a indústria. Os aumentos das tarifas aduaneiras em 1930 e 1932 não tinham por objetivo estimular a produção industrial interna, mas sim incrementar a arrecadação do Estado. Em 1931, foi introduzido o imposto sobre a renda com o

3 Projeto de desenvolvimento nacional não é entendido aqui como um projeto que integra os interesses coletivos da nação. Entendemos que cada classe e facção de classe podem ter um projeto seu para a nação. Ao falarmos em projeto não queremos dizer que as ações das classes e das facções de classe e de grupos estejam previamente definidas por um projeto dado. Mesmo porque esses projetos nunca aparecem acabados. Eles sofrem inflexões, são abandonados etc., a partir da luta social e das mutantes circunstâncias políticas, sociais e econômicas. Como diz Silva (2000, p.13): "Como a sociedade é feita de conflitos, projeto nacional não é entendido como projeto de toda a nação, mas claramente como projeto para uma nação; e vinculado à ação de determinadas frações das elites políticas dirigentes e à dominação de classe". Ver também Corsi (2000). 
objetivo de ampliar a arrecadação e diminuir a dependência da receita pública em relação ao imposto de importação. Essas medidas, somadas à diminuição de gastos, acarretaram um equilíbrio das finanças públicas por volta de 1933 .

A política monetária também foi ortodoxa. Entre 1929 e 1933, observa-se uma redução de $14 \%$ da oferta monetária. As taxas de juros aumentaram em plena depressão. Os rendimentos das Letras Hipotecárias aumentaram de uma média de 6,1\%, em dezembro de 1928/29, para 7\%, em dezembro de 1932 . Os rendimentos dos títulos do governo subiram de 6,2\% para 7,5\% no mesmo período. As taxas de juros só passaram a declinar a partir dessa data. A elevação das taxas de juros reais foi muito maior que esses números, pois se verificou deflação no período. Ou seja, o governo argentino levou a cabo uma política de equilíbrio orçamentário e monetário justamente no período mais agudo da crise, como recomendava a boa ortodoxia neoclássica. Política bem diversa da aplicada por Vargas, que ampliou consideravelmente o gasto público e expandiu a base monetária nesse período, particularmente na fase mais aguda da crise, em 1931 e 1932 (Alejandro, 1973; Romero, 1994; Cano, 2000; Ferrer, 2006).

A diferença entre a política econômica dos dois países pode também ser observada no tratamento dispensado à dívida externa. A Argentina em nenhum momento suspendeu o pagamento de suas dívidas, caso raro na América Latina no período. Manteve seus compromissos externos, apesar das crescentes dificuldades em pagá-los. O Brasil decretou moratória em 1931 e simultaneamente introduziu o controle do câmbio, embora estipulasse, da mesma forma que os controles na Argentina, como prioridade o pagamento dos compromissos externos na alocação das escassas divisas. Imediatamente, Vargas iniciou negociações com os credores externos, o que resultou no Funding Loan de 1931 e, um pouco mais tarde, na assinatura de um acordo provisório, em 1934, que buscava estabelecer pagamentos de acordo com a real capacidade de o país honrálos, mas que se mostrou também insustentável e desembocou na moratória de 1937. 
O coroamento da política argentina nesse período foi o acordo Roca-Ruciman, assinado entre a Argentina e a Inglaterra em 1933. No contexto de acirramento da concorrência internacional e de fechamento das economias nacionais, a Inglaterra exerceu forte pressão sobre o governo argentino, que acabou assinando um acordo desfavorável, pelo qual concedia "câmbio oficial [mais valorizado] às importações inglesas até o montante equivalente ao que a Inglaterra lhe comprava, com tarifas menores em relação às praticadas para terceiros países" (Cano, 2000, p.96). Em contrapartida, assegurava o acesso das exportações agropecuárias argentinas ao mercado britânico. A capacidade de pressão inglesa adivinha da grande dependência do comércio exterior argentino em relação à Grã-Bretanha, ${ }^{4}$ mais especificamente em troca da manutenção das cotas de exportação de carnes argentinas no mercado inglês, o que favoreceu os produtores e frigoríficos argentinos, muitos dos quais eram controlados por empresas inglesas. As divisas obtidas nesse comércio deveriam ser gastas na própria Inglaterra no pagamento das dívidas e na compra de carvão, produtos têxteis e material ferroviário (Romero, 1994, p.108-14).

O Brasil também assinou, em 1935, com os EUA um tratado de comércio, em virtude das pressões do governo norte-americano, que implicou concessões por parte do Brasil. ${ }^{5}$ Esse acordo, a flexibilização dos controles sobre o câmbio a partir de 1933/34 e o novo acordo sobre o pagamento da dívida externa em 1934 pareciam indicar que o Brasil tendia a enquadrar-se na política multilateral dos EUA. Contudo, nesse mesmo período o Brasil estabeleceu forte comércio, com base em acordos bilaterais por meio de marcos de compensação, com a Alemanha, que chegou a ser, entre 1934 e 1938, a segunda parceira comercial brasileira, superando a Ingla-

4 Em 1929, 32,2\% das exportações argentinas destinavam-se à Inglaterra, 17,1\% à França e à Alemanha e apenas 9,8\% aos EUA (Cano, 2000, p.93).

5 Enquanto os EUA concediam rebaixamento de tarifas para produtos como o mate, a castanha-do-pará, o minério de manganês etc. e a não taxação do café, do cacau, do óleo de babaçu etc., o Brasil reduzia ou mantinha as tarifas de 34 produtos manufaturados e dos cereais (Corsi, 2000, p.46). 
terra e ameaçando a posição norte-americana de maior parceiro comercial do Brasil. Essa aproximação com a Alemanha, que parecia disposta a trocar armas e bens de capital por matérias-primas, foi fundamental para a política externa mais independente de Vargas adotada no período inicial do Estado Novo. Enquanto isso a Argentina reforçava seus laços tradicionais com a Inglaterra.

A continuidade da crise internacional, as dificuldades internas, a carência de divisas e os recorrentes desequilíbrios nas contas externas acabaram levando o Estado argentino, a exemplo do que ocorria no Brasil, a intervir, cada vez mais, na atividade econômica a partir de 1933. O aumento dos impostos alfandegários, a introdução de taxas múltiplas de câmbio e os controles de câmbio e importações, mesmo que de forma não intencional, ao fecharem a economia, estimularam o desenvolvimento da indústria, cuja produção voltava-se para o mercado interno. Muitos capitais até então aplicados na agropecuária passaram a diversificar suas atividades investindo também na indústria. Apesar da crise, que atingiu particularmente os pequenos e médios produtores, a agricultura também passou por um processo de diversificação, ampliando-se a produção para o mercado interno, em especial de algodão, de açúcar, de vinho e de erva-mate. Em 1935, foi criado o Banco Central com o objetivo de controlar a política monetária e creditícia, procurando evitar grandes oscilações na oferta de moeda e controlar a atividade bancária. A partir da criação da Junta Nacional de Grãos e da Junta Nacional de Carnes, também foi adotada uma série de medidas visando regular e estimular o setor agropecuário, como, por exemplo, a introdução de preço mínimo para vários produtos (Romero, 1994). O crescimento industrial observado nesse período deu-se a despeito da inexistência de uma política intencionalmente voltada para a industrialização. ${ }^{6}$ A economia cresceu a partir de 1934 também em virtude do melhor desempenho das exportações.

6 O período que vai de 1934 a 1943 foi uma fase de crescimento econômico moderado. O PIB cresceu em média 2,9\% por ano, sendo que a indústria cresceu $4,6 \%$, e o setor agropecuário, $2 \%$.Observam-se mudanças na estrutura do setor 


\section{O projeto de desenvolvimento de Vargas}

Ao contrário da Argentina, que insistia em perseguir uma estratégia ainda presa de certa forma às concepções liberais, o que sugere que as classes dominantes argentinas ainda sonhavam com a "normalização" da situação internacional, o Brasil avançou na definição de uma política de fomento da industrialização. No Estado Novo o projeto de desenvolvimento ganhou consistência. A partir de 1937, no tocante às relações externas, o governo Vargas aprofundou a política exterior mais independente, que vinha tentando implementar desde meados da década. Nesse ano, o governo brasileiro adotou medidas duras contra o capital estrangeiro. Decretou moratória da dívida externa, coisa que a Argentina não fez ao longo de todo o período em pauta, e instituiu novamente o monopólio do câmbio.

Essas medidas, não obstante decorrerem fundamentalmente da crise cambial do segundo semestre daquele ano, buscavam subordinar os pagamentos externos à manutenção do crescimento da economia brasileira. Também denotam uma alteração da postura do governo brasileiro em relação a momentos anteriores de crise cambial, quando evitou entrar em confronto direto com os credores externos. Indícios de radicalização da postura nacionalista de Vargas ficaram evidentes não só nessas medidas e em seus discursos como também em alguns artigos da Constituição outorgada pela ditadura, que estabelecia, entre outros pontos, a nacionalização de setores considerados estratégicos para a economia e a segurança nacional. Outro indício nessa direção foi a assinatura de um acordo de fornecimento de armas com a empresa alemã Krupp. A intensificação do comércio bilateral com a Alemanha talvez seja o aspecto

industrial. Cresceram de maneira mais acentuada os setores têxtil, cujo valor da produção passou a representar $20 \%$ do total; químico, particularmente o refino de petróleo; os produtos de borracha e farmacêuticos e o setor metalúrgico. O valor da produção desses dois últimos setores perfazia, em 1943, $24 \%$ do valor total. Caiu a participação das indústrias alimentares. Entre 1930 e 1934, a participação do produto industrial no PBI subiu de 18\% para 21\% (Cano, 2000, p.96-7). 
mais forte da política externa independente de Vargas. A aproximação em relação à Alemanha e um relativo afastamento em relação aos EUA levaram o Brasil, nas palavras de Moura (1980), a manter uma "equidistância pragmática" das duas potências.

A política externa relativamente independente foi acompanhada de medidas voltadas ao incremento do desenvolvimento calcado no mercado interno e na indústria. A implantação da grande siderurgia foi colocada como a grande prioridade do governo. Intensificou-se a instituição e a remodelação de organismos de regulação e de fomento de setores da economia. Os impostos interestaduais foram finalmente abolidos com o fito de conferir maior unidade ao mercado interno. A integração do mercado interno era considerada central para o desenvolvimento e a unidade política do país. Institui-se também o Plano de Obras Públicas e Reaparelhamento da Defesa Nacional. Embora deficiente, não passando de um orçamento de investimento com recursos próprios, o referido plano tinha por objetivo o desenvolvimento da infraestrutura e da indústria de base.

Em discursos e entrevistas proferidos em fevereiro de 1938, Vargas traçou as linhas gerais do programa de desenvolvimento de seu governo. A nacionalização de setores estratégicos, a priorização da indústria de base, a unificação do mercado interno, a ampliação dos transportes e a introdução do salário mínimo seriam os pilares do programa econômico do Estado Novo. Esse programa, segundo Vargas, exigiria, para ser levado a cabo, um Estado forte, que tivesse abrangente papel na economia. Nessa época, também começa a aparecer a ideia de transformar o Brasil em potência na América do Sul. Um dos principais formuladores dessa proposição foi Osvaldo Aranha (Corsi, 2000).

A execução desse projeto enfrentava obstáculos consideráveis, em particular destacava-se a questão do financiamento da acumulação de capital. Em virtude do pouco desenvolvimento do setor industrial, seria preciso incrementar as importações de máquinas e equipamentos em um contexto de baixa capacidade para importar. As parcas divisas também deveriam cobrir as necessidades de modernização das forças armadas. O clima de acirramento dos con- 
flitos internacionais e particularmente a disputa com a Argentina, que vinha desenvolvendo um programa de modernização de suas forças militares, colocavam também como prioridade do regime incrementar os gastos com a defesa. Enfrentar o problema do financiamento externo era, portanto, chave.

Também seria preciso encontrar meios para financiar o incremento dos gastos públicos e mecanismos para financiar a expansão dos investimentos privados. Porém, inexistia no país um sistema bancário de abrangência nacional que financiasse investimentos de longo prazo. O único banco de abrangência nacional era o Banco do Brasil, os demais eram regionais. O mercado de capitais era diminuto e as principais empresas do país eram familiares, sendo os lucros acumulados às suas fontes fundamentais de financiamento.

Diante da adversa situação internacional, caracterizada, entre outros aspectos, pelos baixíssimos fluxos de investimentos e de empréstimos externos, Vargas, não tendo alternativa mais consistente, passou, de maneira crescente, a apostar na possibilidade de enfrentar esses obstáculos por meio da mobilização do capital nacional. Em discursos, sinalizava nessa direção. O governo procurou articular um esquema de financiamento interno, cujas linhas mestras eram as seguintes: 1. a criação da Carteira de Crédito Agrícola e Industrial do Banco do Brasil; 2. a flexibilização da legislação referente à aplicação dos recursos dos institutos de aposentadoria, permitindo que fossem empregados no financiamento de investimentos com garantia hipotecária (regulamentação do decreto-lei 1918, de 27.8.1937); 3. a implantação do Plano Especial de Obras Públicas, que contava como fonte principal de financiamento com os recursos advindos da introdução de um imposto sobre as operações cambiais, instituído juntamente com o monopólio do câmbio para formar um fundo de investimentos governamentais.

Esse conjunto de medidas denota que, entre 1937 e 1939, o governo passou a apostar na possibilidade de um desenvolvimento mais autônomo. Na concepção de Vargas, o desenvolvimento centrado no capital nacional não significava de maneira alguma qualquer forma de autarquia ou exclusão do capital estrangeiro. Vargas nunca abandonou a ideia segundo a qual o capital estrangeiro seria 
importante para o desenvolvimento do Brasil e sempre procurou atraí-lo, o que sugere que ele não descartava o desenvolvimento associado ao capital externo. No exato momento em que parecia adotar uma postura claramente nacionalista, buscava empresas estrangeiras para levar a cabo seu mais ambicioso projeto, o da grande siderurgia, considerado central para o avanço da industrialização. Ou seja, desenvolvimento mais autônomo não era concebido como excludente em relação ao capital estrangeiro. À época, Vargas procurava esclarecer sua posição em relação ao capital estrangeiro. Este seria bem-vindo desde que respeitasse as leis brasileiras e contribuísse para o desenvolvimento do país (ibidem).

As dificuldades para articular um esquema interno de financiamento da acumulação de capital não eram poucas, em particular destacava-se a resistência das classes dominantes em aceitar uma maior ação estatal na economia e a majoração de impostos (Fiori, 1995). Não obstante a esse importante problema, a questão do financiamento externo parecia chave naquele momento, dado o acanhado desenvolvimento industrial do país. O encaminhamento dessa questão parecia implicar uma aproximação em relação à Alemanha, pois este país parecia disposto a trocar, por meio de acordos bilaterais de compensação, bens de produção e armas por matériasprimas, em especial algodão (Wirth, 1973).

Em um contexto de relativa desarticulação da economia mundial e acirramento dos conflitos interimperialistas, a articulação de financiamento externo passava por alinhamentos políticos e ideológicos. Mas as classes dominantes e o governo estavam rachados, como assinalou Moura (1980), em relação às alianças externas do Brasil. ${ }^{7}$ Trilhar o caminho de um desenvolvimento mais autônomo, naquele

7 Exportadores de algodão e do sul do país inclinavam-se por uma aliança com a Alemanha. Os industriais e os comerciantes ligados ao comércio de importações estavam divididos entre Alemanha e EUA. Os exportadores de café inclinavam-se para os EUA, assim como o setor financeiro. As forças armadas também estavam divididas entre Alemanha e EUA. No governo, Osvaldo Aranha, ministro das Relações Exteriores, defendia uma aliança com os EUA, enquanto outros ministros preferiam a Alemanha. Essas divergências paralisavam o governo Vargas (Moura, 1980). 
momento, implicaria uma aproximação com a Alemanha. Optar por essa saída, entretanto, significava implodir a base de sustentação política do regime e deixar o país à mercê de prováveis represálias norte-americanas. As divergências no interior do Estado e das classes dominantes parecem ter limitado o campo de ação de Vargas, levando-o a deixar em aberto as opções relativas às vias de desenvolvimento do país. A política de Vargas encontrava-se em um impasse, o que levava o Estado Novo a oscilar entre os EUA e a Alemanha.

A possibilidade de superar esse impasse começou a delinear-se no momento em que os conflitos internacionais caminhavam para a guerra aberta. Como parte de sua estratégia para consolidar sua proeminência na América Latina, os EUA convidaram o governo Vargas, em princípios de 1939, para discutir as formas de cooperação econômica entre os dois países. As negociações ocorridas no início desse ano, levadas a cabo por Osvaldo Aranha, então ministro das Relações Exteriores, abriram caminho para o enquadramento do Brasil na política externa norte-americana. Aranha, não seguindo fielmente as instruções de Vargas, como contrapartida de um empréstimo de cerca de 19 milhões de dólares para saldar atrasados comerciais e vagas promessas de créditos de longo prazo, acordou com os norte-americanos a retomada do pagamento da dívida externa e a liberalização da política cambial.

A repercussão no Brasil dos acordos assinados em Washington foi bastante negativa e as críticas a Aranha foram severas. Vargas, no entanto, manteve o ministro em seu cargo. Mas não implementou à risca o que tinha sido acordado. Fez um pagamento simbólico da dívida externa e abriu negociações sobre o assunto, que só chegariam ao fim em janeiro do ano seguinte. O câmbio foi parcialmente liberalizado em abril de 1939. ${ }^{8}$ Isto sugere que ainda existia, em meados

8 Os exportadores passaram a vender no mercado oficial $30 \%$ das cambiais, destinadas para pagar a dívida externa, os atrasados comerciais e os demais compromissos governamentais. As demais operações processariam-se no mercado livre, com exceção das remessas ao exterior, que deveriam adquirir cambiais no mercado livre-especial à taxa mais desvalorizada, o que dificultava essas operações (Corsi, 2000). 
de 1939, uma margem de manobra para o Estado Novo contrapor-se às pressões norte-americanas. A guerra fragilizou a posição brasileira e reduziu ainda mais a margem de manobra de Vargas, o que o levou a readequar seu projeto de desenvolvimento à nova situação. Por outro lado, Vargas, provavelmente, viu nesses acordos uma possibilidade, mesmo que vaga, de superar o impasse em que se encontrava a questão do financiamento do desenvolvimento.

A guerra levou o governo Vargas a seguir o caminho aberto por Aranha, dando início ao alinhamento do Brasil aos EUA que, de forma não linear, culminaria, em agosto de 1942, com a entrada do Brasil no conflito ao lado dos Aliados. A obtenção de financiamento norte-americano para a instalação da grande siderurgia e o incremento das relações militares marcou os primeiros passos desse processo de alinhamento. A entrada na guerra deveu-se tanto às pressões externas quanto às internas, que ganharam terreno a partir do impacto do afundamento de vários navios brasileiros pelos alemães. (Carone, 1988).

Nesse processo de alinhamento, um dos eixos da política externa foi a obtenção de armamentos, de créditos e de bens de capital. Também tomou corpo a ideia de um desenvolvimento integrado ao capital estrangeiro, mas que não comprometeria a soberania nacional. Vargas esperava que se estabelecesse um considerável fluxo de capitais norte-americanos para o Brasil, capaz de contribuir substancialmente para seu desenvolvimento. Com o referido alinhamento, um projeto de desenvolvimento mais autônomo ficava mais distante. Mas Vargas tinha uma interpretação peculiar da aliança com os EUA.

Vargas procurava colocar-se como "aliado especial dos EUA" (Moura, 1980). Além de contar com créditos norte-americanos, essa postura implicaria no apoio dos EUA à pretensão brasileira de firmar-se como potência regional na América do Sul. Indícios dessa evolução foram a organização de uma força expedicionária para atuar diretamente no conflito mundial e a frustrada tentativa de obter um assento permanente no Conselho de Segurança da ONU, quando de sua criação em 1945. Contudo, a posição do 
governo dos EUA quanto ao papel que o Brasil deveria ocupar no cenário internacional não correspondia às expectativas de Vargas. O governo Roosevelt via o Brasil fundamentalmente como um país subordinado.

Enquanto o Brasil alinhava-se com os EUA e buscava assegurar uma posição de proeminência na América do Sul e financiamento para seu desenvolvimento econômico, a Argentina manteve sua velha aliança com a Inglaterra e sua postura de neutralidade em relação ao conflito mundial. A pouca complementaridade entre as duas economias consistia em outro fator a dificultar a aproximação dos dois países. Essa opção, mais tarde, seria considerada um equívoco por setores das classes dominantes argentinas, que a ela creditariam, em parte, a perda de terreno ante o Brasil. Contudo, as fortes pressões norte-americanas e a própria constatação da inevitável derrota da Alemanha levariam a Argentina a romper com sua política de neutralidade (Fausto \& Devoto, 2004).

A Argentina demoraria a definir uma política industrializante e uma nova estratégia de inserção na economia mundial. Isso só viria a ocorrer com Juan Perón. Embora a economia argentina passasse por um processo de diversificação econômica, destacando-se o avanço do setor industrial, não se observa, nesse período, uma clara política industrializante, apesar das medidas voltadas para o desenvolvimento do setor petrolífero e de infraestrutura. Todavia, discutia-se no parlamento, na imprensa e nas associações de classe os rumos da economia argentina. No início dos anos 1940, os debates centraram-se em torno do Plano de Reativação Econômica, o chamado Plano Pinedo, apresentado em 1940 por Frederico Pinedo, então ministro da Fazenda do governo Ramón S. Castilho.

O Plano Pinedo foi uma tentativa de adequar a economia argentina à nova situação da economia mundial que vinha se delineando desde a Primeira Guerra Mundial e, ao mesmo tempo, responder às mudanças em curso na própria economia argentina. As principais medidas propostas pelo plano eram as seguintes: 1. estimular o setor da construção civil; 2. instituição da compra das colheitas pelo Estado como forma de garantir preço mínimo para os produtos 
agrícolas; 3. estimular o crescimento da indústria (El Plan de Reactivacion económica, 1979, p.403; Llach, 1984).

Embora Pinedo não questionasse o papel central do setor exportador para a Argentina, ele advogava a necessidade do desenvolvimento da indústria, das finanças e dos serviços para o equilíbrio geral da economia. A proposta era desenvolver apenas as indústrias consideradas "naturais", ou seja, aquelas indústrias que elaboravam matérias-primas nacionais (carne, lã, milho, leite, algodão, madeira, zinco, cal, cimento etc.) e que possuíssem eficiência para competir no mercado externo.

Dessa forma, o plano propunha uma industrialização relativamente limitada e voltada para as exportações, particularmente para os EUA e para os países vizinhos. Uma das ideias centrais do plano era redirecionar a economia argentina para os EUA. O plano apontava para a necessidade de diversificar as exportações e incrementar seu valor agregado, só assim seria possível sustentar o desenvolvimento calcado nas exportações. Pinedo tinha clareza das tendências que vinham se delineando na economia mundial e propunha um estreitamento das relações com o novo centro hegemônico e o abandono das estreitas relações com a Inglaterra. A Argentina não poderia mais depender de uma potência decadente como mola propulsora de suas exportações e, por conseguinte, de sua economia. Com o avanço da industrialização, seria necessário incrementar as importações de bens de capital e uma forma de financiá-las seria pela obtenção de superávits no comércio com os norte-americanos. O crescimento das exportações para os EUA também ajudaria a enfrentar o incremento do peso das dívidas em dólares e os déficits comerciais com esse país. Ademais, no contexto da época, apenas os EUA teriam condições de fornecer tais bens. Contudo, os defensores do plano pareciam menosprezar um importante obstáculo, qual seja: a falta de complementaridade com a economia norteamericana, que poderia inviabilizar a estratégia sugerida (Llach, 1984; Etulain, 1991; Romero, 1994; Devoto, 2003).

Pinedo considerava que o mercado interno argentino não era suficientemente amplo para sustentar um abrangente processo de 
industrialização baseado na substituição de importações. Por isso, buscava definir uma estratégia de desenvolvimento baseada nas vantagens comparativas da Argentina e isso implicava não apenas fomentar a agropecuária, mas também certos setores da indústria que tinham condições de competir no mercado mundial. Era uma estratégia de industrialização voltada para as exportações. A Argentina, dotada de vastos recursos naturais, deveria, segundo Pinedo, aproveitar as vantagens comparativas decorrentes desse fato.

O Estado teria uma função-chave no financiamento do desenvolvimento, mobilizando e direcionando o crédito público e privado para os setores considerados prioritários, em especial para a indústria. Mas o plano não contemplava uma ação mais direta do Estado na economia. ${ }^{9}$ A diferença com a política seguida no Brasil nesse período é acentuada, pois aqui se observava a ampliação da ação estatal na economia com a criação de empresas estatais e de inúmeros órgãos de fomento e regulação de setores da economia. ${ }^{10}$

O Plano Pinedo buscava, como assinala Etulain (1991, p.5160 ), estabelecer uma estratégia de desenvolvimento industrializante sem, no entanto, ferir os interesses do setor hegemônico, defensor de políticas econômicas liberais. O plano favorecia, ainda segundo o referido autor, os interesses do que ele chama de setores oligopolizados da burguesia urbana, composto por poucos grandes grupos econômicos que tinham se originado na atividade exportadora, mas que vinham diversificando suas atividades em direção aos setores industriais, sobretudo, vinculados à elaboração de matérias-primas nacionais, grupos como Bunge\&Born, Tornquist, Bemberg e Braun Menéndez. Para esses grupos, uma aproximação

9 "Podrá pensarse que una acción de esta naturaleza presupone la intervención directa del Estado en los negocios. Ni si tiene esse propósito ni se justifica esa intervención”(El Plan de reactivación Económica, 1979, p.404).

10 "Acompana a este mensaje el projecto de ley de financiación, el más importante quizá de elllos [...] Tiene el pais quantiosos recursos monetarios [...] se há preparado un sistema de financiación que se propone movilizar esos recursos disponibles facilitarlos a la actividad priivada" (El Plan de Reactivación Económica, 1979, p.403-405). 
com a economia norte-americana poderia significar uma saída para a crise do modelo agrário-exportador à medida que o mercado dos EUA absorvesse os excedentes exportáveis. O plano também favoreceria empresas estrangeiras que atuavam no país. Esse plano expressaria “uma 'opção' moderna e factível para o liberalismo argentino”. Dessa forma, o plano não poderia ser reduzido a uma proposta de política de emergência, adotada no contexto de guerra e voltada para incrementar o comércio com outros países da região.

No cômpito geral, as resistências ao plano nos setores dominantes eram fortes, indicando a fragilidade do predomínio dos "grandes grupos oligopolizados do setor urbano" (idem). O plano de reativação econômica acabou sendo rejeitado no Congresso, apesar do apoio dos industriais. Assim, morreu uma tentativa que poderia ter sido uma alternativa ao modelo de industrialização via substituição de importações. O Plano Pinedo estava, em certo sentido, deslocado de seu contexto histórico, pois defendia como estratégia de desenvolvimento a expansão de determinados setores da indústria voltados para diversificação e o incremento das exportações em um momento de relativa desarticulação da economia mundial. Mesmo no período que se seguiu ao fim da Segunda Guerra Mundial, o crescimento econômico esteve calcado no mercado interno. Só mais tarde seriam abertas possibilidades para estratégias de desenvolvimento que enfatizavam as exportações.

A questão da industrialização não morreu na Argentina com a não aprovação do Plano Pinedo. Alguns anos depois, no governo de Juan Perón, essa questão ocuparia o centro do debate econômico.

Enquanto isso, no Brasil, a questão de um desenvolvimento mais autônomo parecia retornar ao debate ao final da guerra. A postura nacionalista mais firme ao final do Estado Novo, delineada a partir da introdução de um rígido controle de importações e de uma legislação antitruste, que atingiam os interesses do capital estrangeiro, não significou o abandono da linha política definida com o alinhamento aos EUA. No contexto de crise do Estado Novo, marcado por pressões internas e externas pelo fim da ditadura, essas medidas relacionavam-se muito mais com a tentativa de Vargas 
aproximar-se das classes populares e permanecer no poder do que a ruptura com a estratégia de desenvolvimento calcada em amplo financiamento externo. A erosão de sua base de sustentação política junto aos setores das classes dominantes que o apoiavam levou Vargas, a partir de 1942/1943, a imprimir uma política de mobilização dos trabalhadores com o objetivo de criar uma nova base de sustentação que lhe permitisse controlar a transição do regime e, se possível, permanecer no poder. ${ }^{11}$ Foi a partir desse momento que tomou corpo o projeto trabalhista de Vargas, centrado no mito da doação da legislação social, que era acalentado desde os anos 1930 (Paranhos, 1999).

Vargas achava ser possível industrializar o Brasil, mudar sua inserção na economia mundial, garantir a soberania nacional e conseguir um papel de destaque na América Latina, contando para tanto com o financiamento externo e o forte apoio político norteamericano. Com essas metas, o projeto de Vargas encontrou crescente dificuldade para se concretizar em um contexto em que os EUA firmavam-se como superpotência.

A Argentina, no tocante à definição de uma política industrializante, saiu atrás do Brasil. Esse atraso relativo denota, de um lado, a força dos setores agrário-exportadores na Argentina, defensores ferrenhos de políticas econômicas liberais, e, de outro, a fraqueza do desenvolvimento da indústria argentina.

No período em pauta, não havia espaço para estratégias de desenvolvimento calcadas nas exportações. O bom desempenho econômico de vários países que vinham se desenvolvendo com base no mercado interno e na ampla ação estatal na economia indicava que esta seria a estratégia mais plausível de desenvolvimento.

11 AomesmotempoemqueVargasconclamava os trabalhadores mobilizarem-se, uma série de medidas que respondiam às necessidades e às aspirações dos trabalhadores era adotada, entre elas a promulgação da Consolidação das Leis do Trabalho (CLT), o aumento do salário mínimo e o congelamento de aluguéis e dos preços de produtos de primeira necessidade. 


\section{Referências bibliográficas}

ABREU, M. P. Crise, crescimento e modernização autoritária (1930-1945). In: (Org.). A ordem do progresso: cem anos de política econômica republicana (1889-1989). Rio de Janeiro: Campus, 1992.

O Brasil e a economia mundial (1930-1945). Rio de Janeiro: Civilização Brasileira, 1999.

ALEJANDRO, C. D. Ensaios sobre la historia económica argentina. Buenos Aires: Amorrotou, 1973.

ASHWORT, W. Breve história de la economia internacional: 1850-1950. México: Fondo de Cultura Económica, 1958.

BANDEIRA, M. Estado nacional e política internacional na América Latina: o continente nas relações Argentina-Brasil (1930-1992). São Paulo: Ensaio, 1993.

BASTOS, P. P.Z. Raízes do desenvolvimento associado: comentários sobre sonhos prussianos e cooperação panamericana no Estado Novo (19371945). In: Revista Economia, Brasília, v.5, n.3, dez. 2004.

BEIRED, J. L. B. Breve história da Argentina. São Paulo: Ática, 1996.

BLOCK, F. Las origenes del desorden económico internacional. México, Fondo de Cultura Económico, 1980.

CANO, W. Soberania e política econômica na América Latina. São Paulo: Editora Unesp, 2000.

CORSI, F. L. Projeto nacional de desenvolvimento e globalização. Relatório de pesquisa. Marília: FFC-Unesp, 1997.

. Estado Novo: política externa e projeto nacional. São Paulo: Editora Unesp, 2000.

. Development and State during the brasilian Estado Novo. In: PERISSINOTTO, Renato. M. (Org.). Entrepreners, State and interest representation in Brazil. New York: Nova Science Pusblishers, 2003.

DEVOTO, F. J. Para uma história da Argentina no século XX. In: AGGIO, A.; LAHUERTA, M. (Orgs.). Pensar o século XX: problemas políticos e história nacional na America Latina. São Paulo: Editora Unesp, 2003.

DONGI, H. História contemporânea de América Latina. Madrid: Alianza, 1972.

DRAIBE, S. M. Rumos e metamorfoses: um estudo sobre a constituição do Estado e as alternativas da industrialização no Brasil (1930-1960). Rio de Janeiro: Paz e Terra, 1985.

ETULAIN, C. Intervenção do Estado, economia e petróleo: um estudo sobre liberalismo e nacionalismo na Argentina. Campinas, 1991. Dissertação (mestrado) - IE-Unicamp, 1991. 
Sociologia, peronismo e esquerda na Argentina. In: Estudos de Sociologia, Araraquara, n.13/14, p.49-75, 2002.

FAUSTO, B. Estado, classe trabalhadora e burguesia industrial (19201945). In: Novos Estudos Cebrap, São Paulo, n.20, 1988.

; DEVOTO, F. J. Brasil e Argentina: um ensaio de história comparada (1850-2002). São Paulo: Editora 34, 2004.

FERREIRA, J. L. A democratização de 1945 e o movimento queremista. In: ; DELGADO, L. A. N. (Orgs.). O Brasil republicano: o tempo do nacional estatismo. Rio de Janeiro: Civilização Brasileira, 2003.

FIORI, J. L. Em busca do dissenso perdido: ensaios críticos sobre a festejada crise do Estado. Rio de Janeiro: Insight, 1995.

FODOR, J. G.; O'CONNELL, A. La argentina y la economia atlantica en la primeira mitad del siglo XX. In: Desarollo Económico, Buenos Aires, v.13, n. 49, 1973.

FURTADO, C. Formação econômica do Brasil. 18.ed. São Paulo: Nacional, 1982.

GOMES, Â. C. A invenção do trabalhismo. São Paulo: Vértice, 1988.

HOBSBAWM, E. J. A era dos extremos: o breve século XX: 1914-1991. São Paulo, Companhia das Letras, 1995.

LLACH, J. J. El Plan Pinedo de 1940, su significado histórico y los orígenes de la economia política del peronismo. In: Desarrollo Económico, 23(92), p.515-56, 1984.

MADDISON, A. Dos crisis: América Latina y Asia (1929-1938/19731983). México: Fondo de Cultura, 1986.

MOURA, G. Autonomia na dependência: a política externa brasileira (19351942). Rio de Janeiro: Nova Fronteira, 1980.

PANDOLFI, D. (Org.). Repensando o Estado Novo. Rio de Janeiro: FGV, 1999.

PARANHOS, A. O roubo da fala: origens da ideologia do trabalhismo no Brasil. São Paulo: Boitempo, 1999.

PLAN DE REACTIVACION ECONOMICA In: Desarollo Económico. Buenos Aires, v.19, n.75, 1979.

ROMERO, L. A. Breve história comtemporánea de Argentina. México: Fondo de Cultura Econômica, 1994.

SILVA, S. S. Prefácio. In: CORSI, F. L. Estado Novo: política externa e projeto nacional. São Paulo: Editora Unesp, 2000.

TELLA, T. S. et al. Argentina, socied de masas. Buenos Aires: Eudeba, 1966.

WIRTH, J. A política de desenvolvimento na era Vargas. Rio de Janeiro: FGV, 1973. 



\section{8 \\ A QUESTÃO DO CONSENSO DURANTE \\ A DITADURA MILITAR ARGENTINA: PROBLEMAS METODOLÓGICOS E CONTEXTOS HISTORIOGRÁFICOS (1976-1983)}

Daniel Lvovich ${ }^{1}$

As análises acerca da existência de formas de consenso - ativo ou passivo - nos regimes autoritários e totalitários da Europa e da América Latina cresceram em número e na sofisticação de suas perguntas nas últimas décadas. Desse modo, as investigações sobre esse tipo de fenômeno, sem abandonar a perspectiva que indaga na natureza a estrutura dos regimes, tentam também dar conta das atitudes de diferentes segmentos da sociedade: desde o repúdio e a resistência até o apoio patente e ativo. As atitudes das sociedades são, em geral, consideradas ao mesmo tempo como uma condição de possibilidade para a implantação desses tipos de regimes e como produtoras da ação - quer da coação quer da geração de consenso dos mesmos.

A questão do consenso começou a surgir como objeto de estudo da historiografia sobre as ditaduras europeias a partir da introdução, por Renzo de Felice, em meados da década de 1970, dessa

1 Doutor em História e professor da Universidade Nacional de General Sarmiento, é autor de Nacionalismo y antisemitismo en la Argentina. Buenos Aires: Vergara, 2003 e El nacionalismo de derecha en la Argentina. Buenos Aires: Claves Para Todos, 2006, e coeditor de Las politicas sociales en perspectiva histórica. Argentina. 1870-1950. Buenos Aires: UNGS, 2006. 
categoria interpretativa no debate sobre a natureza do fascismo. ${ }^{2}$ Enquanto esse historiador afirmava que o regime fascista italiano atingiu o momento de máxima solidez e adesão entre 1929 e 1934, outros repudiaram a possibilidade de aplicar o conceito de consenso às ditaduras do século XX, por considerar que este define a relação existente entre governantes e governados em regimes que permitem a livre expressão da vontade individual e social, e não naqueles caracterizados pela preeminência do aparato repressivo, do monopólio político e da censura. ${ }^{3}$ Também se tem debatido a natureza do consenso de que desfrutou o regime fascista. Alguns autores negam que o fascismo tenha desfrutado de um verdadeiro consenso, pois não se pode considerar como tal a aceitação passiva e resignada do regime. Nesse sentido, Nicola Tranfaglia considera que só quando existe um apoio entusiasta e uma participação ativa pode-se afirmar que um sistema político possui o apoio das massas (Vicente, 1995, p.144). A posição contrária - mantida, entre outros, por De Felice e Mosse - afirma que o consenso efetivo conseguido pelo fascismo não equivale à unanimidade dos apoios nem à posse permanente de adesões entusiastas.

Nas últimas décadas, aumentou a convicção de que todas as ditaduras utilizaram políticas específicas para manter seus apoios originais e, inclusive, ampliá-los, mesmo entre os setores que originalmente consideravam hostis. A historiografia sobre as ditaduras da Espanha e da Alemanha demonstra que mesmo os regimes mais fortemente repressivos contaram com uma base de sustentação relativamente ampla e não redutível a uma classe ou segmento de classe social em particular. ${ }^{4}$

2 Ver De Felice (1974), em particular o segundo capítulo, "Gli anni del consenso: Il paese". Sobre o impacto das posturas de De Felice na historiografia do fascismo, ver Gentile (1986).

3 Essa é a postura de Nicola Tranfaglia, Gaetano Arfé e Máximo Salvadori, exposta por Vicente (1995, p.144). A respeito, ver também Painter (1990).

4 Para o caso alemão, entre uma muito extensa bibliografia, podemos citar como exemplo. Um texto que envolve o consenso, mas abarca também a participação dos perpetradores é o de Browning (2002). Pelo impacto que gerou, é quase um lugar-comum citar Goldhagen (1997). Criticado, entre outros fatores, por sua 
Nesse sentido, mostrou-se com acerto que "a formação do consenso efetivo não é um fenômeno espontâneo e tacitamente aceito", mas é induzido a partir do poder, "através de um conjunto de processos, instituições e aparatos que realizam as operações destinadas à organização do consenso, isto é, a produzir e estender comportamentos de adesão na relação com o poder" (Guaitini \& Seppelli, 1978, p.149-50).

Entretanto, e para qualquer tipo de regime político, o sucesso da operação hegemônica dependerá das formas em que tal apelação é processada pela população à qual se dirige. Em algumas análises enfatiza-se o peso do fator ideológico na conformação do consenso, como no livro de Y. Cohen (1989) sobre a classe operária brasileira durante a ditadura militar, significativamente intitulado The manipulation of consent. Em outras, ao contrário, destaca-se o papel ativo dos indivíduos subalternos que, em vez de concordar ideologicamente com seus dominadores, reconhecem seu caráter de dominados como marco a partir do qual definirão suas práticas. ${ }^{5}$

As explicações sobre os fatores determinantes na criação do consenso são múltiplas, dando por certo que se a indicação da existência de setores sociais diretamente beneficiados no plano econômico social pelas políticas das ditaduras esclarece parte do fenômeno, as atitudes políticas em que se fundamentou o consentimento transcendem muito esta causa. ${ }^{6}$

excessiva simplificação e monocausalidade, pode-se ver essas indicações em Finchelstein (1999). Um balanço da historiografia da resistência contra o nazismo em Kershaw (2004). Para a Espanha franquista, ver Luzón (1991); Sánchez et al. (1993).

5 Esta é a perspectiva que inspira os ensaios compilados por Joseph \& Nugent (1994).

6 Em relação às explicações da existência desse consenso, Ian Kershaw e Detlev Peukert sugeriram que a popularidade de Hitler estabeleceu uma das bases sobre as quais se fundou e se construiu o regime. Peukert declara que a aclamação popular do Führer articulou certo consenso básico por parte da maioria da população a favor do sistema, consenso este que não se viu afetado pelas manifestações de desacordo em alguns aspectos concretos (Peukert, 1987, p.67). Kershaw, por sua vez, afirma que a pessoa de Hitler constituiu o ponto focal do consenso básico que criou uma força integrativa crucial no sistema nazista. 
As investigações que se referem ao caso particular da ditadura militar instaurada na Argentina em 1976 coincidem em assinalar que, em um primeiro momento, uma maioria significativa da sociedade apoiou o golpe de Estado, pelo fato de ter sido considerado como uma saída para a crise econômica, o desmoronamento institucional e a violência política que caracterizaram os meses anteriores à intervenção militar. Também é ampla a coincidência em assinalar que a ditadura pode consumar-se por ter-se articulado com uma longa tradição de autoritarismo e de negociação dos direitos do adversário político, cujos elementos reorganizou e levou aos seus extremos. ${ }^{7}$

Entretanto, essa coincidência não se estende a outros aspectos relativos ao problema do consenso. Nesse sentido, enquanto alguns estudos enfatizam a capacidade do terror estatal para eliminar qualquer forma de resistência, oposição ou dissidência (Acuña \& Smulovitz, 1995, p.31-5), outros trabalhos que analisam a lógica do terror não deixam de enfatizar seu caráter produtor de sujeitos políticos que obedecem de maneira absoluta, mas voluntária. Nessa perspectiva inscreve-se um trabalho pioneiro publicado quando a ditadura ainda se encontrava no poder, e cuja influência não foi suficientemente reconhecida, El método de destrucción, de Juan Corradi. Esse autor destacava que, enquanto os grupos dominantes procuraram, em 1976, dar prioridade ao restabelecimento do monopólio da coerção, a extrema fragmentação e anomia geraram nos grupos subordinados, e em particular nos setores médios, "uma demanda primitiva de ordem e uma disposição generalizada para assinar um pacto hobbesiano ou, pelo menos, respaldar a aquisição enérgica de poder soberano por parte dos ditadores" (Corradi, 1996, p.89). Nesse contexto, o objetivo da política do terror não foi apenas

O mito de Hitler foi o fator indispensável em sua função de integração para estabelecer uma base maciça de consenso entre o povo alemão em torno daqueles objetivos e políticas identificados com o Führer (Kershaw, 1987, p.4 e 253). Nos casos da Espanha e de Portugal, por outro lado, destacou-se a função consensual da ideologia nacionalista - católica e de instituições destinadas a propagá-la. Entre outros, ver Botti (1992, p.142), Pablo (1994) e Torgal (1994).

7 Sobre este ponto, ver Romero (2001) e Calveiro (1998). 
controlar, mas também mudar os atores sociais, privando os indivíduos da oportunidade de prever as consequências de suas ações, já que se trata de uma forma de poder na qual a conformidade não garantia a segurança. Corradi comparou o caso argentino ao modelo previsto pelo Behemot de Franz Neumann, ao afirmar que se tratava de um tipo de sociedade na qual "os grupos que governam controlam diretamente o resto da população, sem a mediação desse aparato racional, embora coercitivo, conhecido como Estado" (idem, p.103). Sua conclusão é que as convenções tradicionais, como o companheirismo e a convivência civil, cederam diante de um cinismo penetrante, com o qual a sociedade civil atingiu seu "grau zero".

Uma série de estudos tentou explicar as relações de apoio explícito, consenso passivo ou oposição à ditadura, levando em conta as atitudes desenvolvidas pela grande imprensa e pelas cúpulas dos partidos políticos, das associações empresariais e profissionais, dos sindicatos e da Igreja Católica, entre outros atores.

Em relação ao comportamento dos partidos políticos, Hugo Quiroga (1994, p.492) afirma que a descontinuidade institucional iniciada em 1930 não pode ser considerada como uma ruptura do sistema político. Ao contrário, o sistema político argentino funcionou na realidade histórica por meio de uma articulação que combinou os governos militares com os governos civis. Desse modo, no interior do mesmo sistema coexistiram dois polos antagônicos: o democrático e o autoritário. Nessa estrutura, as Forças Armadas competiram pelo poder frente às outras forças políticas, intervindo como uma força política estatal. O golpe de Estado de 1976 não foi excepcional em relação aos seus precedentes quanto às dificuldades para conseguir construir alguma forma de legitimidade. Quiroga afirma a respeito que a aceitação social manifestada em 24 de março diante da alternativa militar não chegou a transformar o consenso inicial em uma fórmula de legitimação autoritária estável e certa. $\mathrm{O}$ autor afirma que com o golpe de 1976, uma parte relevante da população manifestou, "passiva e silenciosamente, sua crença em que a necessidade de recuperar uma ordem social perversa só poderia ser encontrada durante a dominação militar" (ibidem). Entretanto, 
o regime militar de 1976 não se baseou na conquista de uma nova forma de legitimação, mas na crise de legitimidade do regime civil precedente. A respeito disso, Quiroga (ibidem) declara:

Diante do fracasso civil, a alternativa militar adquire realidade para grande parte da população. Isto não é mais do que a consequência de um sistema político que combina em seu funcionamento os governos civis e os militares. Em consequência disso, o que legitima a dominação militar é o funcionamento de um sistema político particular que incorpora em seu interior as forças armadas como um componente essencial e permanente. Em outras palavras, o sistema político opera como modo de legitimação da dominação militar.

Nesse contexto, a maior parte dos partidos políticos mostrou-se desleal (MID, PSD, Fufepo, PDP etc.) ou semileal (PJ, UCR) ao sistema democrático. Enquanto os primeiros ofereciam seu apoio e as competências individuais de seus membros para se integrarem à condução do governo, os segundos não outorgaram um apoio aberto ao regime militar, mas manifestaram paciência e tolerância diante do estabelecimento da ditadura. Quiroga é categórico quando assinala que a intervenção militar foi legitimada pela totalidade das formações políticas mediante o reconhecimento do papel das Forças Armadas na luta contra a subversão, já que "essa foi a legitimidade de origem permanentemente invocada pela administração de fato" (ibidem). ${ }^{8}$

8 Conclusões similares encontram-se em Yanuzzi (1996) e foram retomadas recentemente por Pucciarelli (2004, p.161). Em um sentido similar, para o caso espanhol Richards (1999, p.9 e 18) declarou que, apesar de o franquismo "ter obtido sua legitimidade em uma guerra contra seu próprio povo", e de "o regime se basear antes de tudo na ameaça constante de coerção e na recordação de suas origens violentas", existiu uma base social relativamente ampla e congruente que apoiou a rebelião e o franquismo. Richards explica o apoio das classes médias e médias baixas espanholas ao franquismo porque "os setores importantes da sociedade eram uma circunstância favorável para uma ideologia que tentava a todo momento criminalizar os conflitos sociais, transformá-los em uma manifestação patológica e aplicar-lhes um tratamento médico". 
Tais atitudes, na ótica de Quiroga, não foram apenas patrimônio dos partidos políticos: "A falta de fidelidade é também imputável à maioria dos cidadãos que buscam, na dominação militar, formas alternativas de legitimidade" (idem).

Entretanto, essas afirmações não desfrutam de um acordo unânime. Enquanto Quiroga destacou a centralidade da "luta antissubversiva" como elemento gerador de consenso, Sidicaro (p.21) e Vezzetti (2002, p.88-9) concordaram ao assinalar que a destruição das organizações guerrilheiras ganhou importância muito tardiamente no discurso legitimador da ditadura, uma vez que o regime militar fracassou em cada uma das metas do seu projeto de refundação. ${ }^{9}$

Outro exemplo no mesmo sentido resulta do contraste entre a afirmação de Quiroga sobre a importância que as Forças Armadas deram desde o início à legitimação de sua intervenção - pretendendo organizar o consenso por meio de um discurso que constatava as crises sucessivas que o país atravessou, a teoria do vazio de poder e a denúncia do perigo da "subversão terrorista" - com a postura com relação a Novaro \& Palermo. Em seu livro recentemente lançado, esses autores declaram que, nos dias de sua ascensão ao poder, os militares encontraram no caráter difuso e reativo do consenso social a confirmação que necessitavam para concluir na "conveniência de estabelecer distâncias claras frente à sociedade, que percebiam como carente de intenções ou aspirações de grande inspiração e globalmente enferma" (Novaro \& Palermo, 2003, p.25). Esse diagnóstico não excetuava sequer os grupos mais entusiastas do golpe, como os grandes empresários e latifundiários. Novaro e Palermo concluem, portanto, que nas etapas iniciais do golpe os militares que estavam no poder não consideravam a necessidade de garantir o acompanhamento civil, "pois estavam imbuídos de uma fé messiânica em seus planos de refundação e regeneração" (ibidem).

9 Uma postura um pouco mais matizada a respeito está presente no recente artigo de Sidicaro, "Coaliciones golpistas y dictaduras militares: el 'proceso' en perspectiva comparada”, incluído em Alfredo Pucciarelli (Comp.), Op. Cit. 
Entretanto, essa perspectiva contrasta com o que se depreende da leitura do Plan de acción psicológica do Exército - publicado pelo jornalista EnriqueVázquez -, em que se estabelece a utilização de diversos instrumentos de propaganda para conseguir a adesão popular à chamada "guerra contra a subversão" (Vázquez, 1984, p.264-9).

Analisando o caso particular da UCR, Tcach (s. d., p.34) realizou uma análise graduada das distintas posições internas em relação ao governo militar. Para analisar as posturas radicais, Tcach distinguiu entre os partidos situados "dentro do regime" e "fora do regime". ${ }^{10}$ A distinção fundamenta-se em dois aspectos: a contribuição para a formação de equipes de governo e a incidência na elaboração e execução das políticas públicas. Tcach afirma que a UCR não cedeu seus quadros nem incidiu sobre as políticas oficiais. Houve intendentes de afiliação radical em diversas localidades, em geral pequenas, que se justificavam pela possibilidade de influir na micropolítica local, mas aos quais o comitê partidário bonaerense, presidido por Juan Carlos Pugliese, solicitou suas renúncias em 1981. Partindo dessa perspectiva, a UCR foi, diferentemente do Fufepo, um partido situado "fora do regime".

Um segundo nível de análise permite distinguir os tipos de oposição em função da natureza do questionamento e da saída política proposta. Uma oposição pouco intensa é aquela que questiona aspectos parciais da política oficial, mas na medida em que não propõe uma saída política imediata, legitima implicitamente a existência do regime. Uma oposição intensa questiona os fundamentos do regime, mas está propensa a aceitar uma saída pactuada. A UCR passou de um tipo de oposição pouco intensa (1976-1977) a uma intensa (1978-1982) e, depois das Malvinas, a uma muito intensa (1982-1983).

Um valioso aporte para considerar de uma perspectiva empiricamente informada o papel de um ator social em relação à ditadura foi a análise sobre a Igreja Católica realizada por Emilio Mignone. Segundo o modelo de análise de Mignone (1986), na cúpula ecle-

10 O critério foi extraído de Biescas \& Manuel (1981). 
siástica confluíram a vontade de eliminar a ameaça política no nível nacional com a de retomar o controle interno da instituição, questionado por múltiplos sinais de dissidência que foram surgindo nos anos anteriores, por meio de uma estratégia repressiva delegativa. Do exposto por Mignone depreende-se que boa parte da cúpula eclesiástica não só aderiu ao golpe de Estado, mas foi co-responsável pelo terrorismo de Estado, já que os principais dignitários eclesiásticos "foram devidamente informados dos planos para derrubar o regime constitucional", e inclusive o método repressivo que seria empregado. Nesta perspectiva, conseguiu-se um acordo segundo o qual "o regime teria caminho livre em sua ação repressiva e contaria com o apoio do Episcopado" (idem, p.47).

Por sua vez, as principais organizações empresariais da Argentina podem ser, sem dúvida, catalogadas como defensoras e, em muitos casos, cúmplices do terrorismo de Estado ditatorial. São conhecidos os casos extremos de empresas - Ford, Mercedes Benzque convocaram as Forças Armadas às suas sedes e entregaram listas dos trabalhadores que seriam sequestrados. Até mesmo nos últimos dias da ditadura as organizações patronais demonstraram sua lealdade aos militares então caídos em desgraça, como manifestaram na solicitação publicada no jornal Convicción em 21 de setembro de 1983 e assinada, entre outros, pela Sociedade Rural Argentina, pela Bolsa de Comércio de Buenos Aires e pelo Conselho Empresarial Argentino, entre muitos outros (Novaro \& Palermo, 2003, p.505-6).

Como assinalaram Molinero \& Ysás (1998) para o caso espanhol, em geral a historiografia prestou mais atenção às atitudes das classes trabalhadoras do que das classes burguesas e das médias, provavelmente porque se dava por certo seu apoio ao regime ditatorial. Entretanto, os estudos de caso demonstram a necessidade de rever essas suposições.

$\mathrm{Na}$ verdade, a historiografia europeia percebeu os esforços dos distintos regimes ditatoriais para obter o apoio das classes trabalhadoras, assim como as diferentes atitudes destas frente àqueles regimes. Além das diferentes interpretações sobre o papel da classe 
operária alemã frente ao nazismo, ${ }^{11}$ fica claro que as políticas sociais do regime de Hitler foram uma tentativa de incorporação desses setores, com sucesso limitado, segundo o principal estudioso dessa estratégia, Mason (1993). ${ }^{12}$

No caso italiano, o estudo já clássico de Passerini (1987) demonstrou os limites da capacidade de penetração ideológica do estado fascista na classe operária e destacou a existência de formas de resistência simbólicas enraizadas nas tradições populares. Em relação à ditadura franquista, foi indicado que, embora a maior parte da classe operária repudiasse a ditadura, os trabalhadores mantiveram-se passivos, tanto devido à política de terror quanto ao fato de que a ausência de expectativas razoáveis de mudança estimulou sua resignação (Molinero \&Ysás, 1998). No mesmo sentido, a luta pela sobrevivência física impediu a organização da resistência, pois os setores populares deviam concentrar todos seus esforços em garantir sua subsistência cotidiana (Richards, 1999, p.195). A hostilidade geral não deve ocultar a existência de guarnições operárias em que a atitude predominante foi a indiferença política, especialmente entre os setores que haviam permanecido à margem da intensa mobilização da década de 1930. Também houve setores operários que apoiaram a ditadura por motivos ideológicos ou devido às oportunidades de trabalho e ascensão social que o Estado franquista ofereceu a seus partidários (Molinero \& Ysás, 1998).

11 Alguns autores enfatizam a resistência operária nos anos da ascensão do nazismo ao poder (Bologna, 1999) e as dificuldades da ditadura alemã para incorporar plenamente os trabalhadores (Mason, 1995). Em sentido contrário, Gellately declara que os trabalhadores não foram imunes à chamada do nazismo, e na verdade aceitaram Hitler de boa vontade e compartilharam em grande medida seus objetivos, enquanto Christopher Browning, (op. cit., p.101) mostrou que uma parte dos membros do batalhão que participou de muitas operações genocidas na União Soviética e na Polônia provinha da classe operária e, inclusive, de militâncias de esquerda antes de 1933.

12 Mason afirma que, diante da impossibilidade de desenvolver outras práticas de resistência, é preciso entender as greves e outras formas de luta dos trabalhadores alemães como dirigidas mais contra o Estado do que contra os empregadores e, portanto, privilegiando sua face política sobre a econômica. 
Voltando ao caso argentino, os trabalhos que se referiram às atitudes do movimento operário oscilaram entre um polo no qual se destacava a imobilidade das organizações sindicais durante a ditadura (Delich, 1983) e outro concentrado nas estratégias de resistência (Falcón, 1988). Entretanto, é necessário distinguir nesse caso entre a ponderação de Falcón, que assinalou a existência de uma resistência pouco articulada, de tipo molecular, nos locais de trabalho e de caráter fundamentalmente defensivo, e o de Pablo Pozzi, mais favorável a considerar as formas de oposição operária à ditadura, que reconstrói minuciosamente, como um fator determinante no fracasso do regime militar. Pozzi afirma que, apesar de todo o encarceramento ou exílio de parte da maioria dos líderes sindicais e da intervenção da CGT e de todas as grandes agremiações, a burocracia sindical entrou em um processo de negociação e colaboracionismo com a Junta Militar. Em uma perspectiva similar à de Mignone para o caso da Igreja, Pozzi assinala que "entre as Forças Armadas e a burocracia sindical havia algo mais em comum: ambas se sentiam profundamente ameaçadas por tendências classistas e combativas que surgiram no sindicalismo durante a década de 1960". Nessa atitude, uma minoria dos dirigentes foi abertamente cúmplice dos crimes das forças repressivas, enquanto a maioria calou-se diante das perseguições sofridas pelos trabalhadores (Delich, 1983, p.114-5).

Esses trabalhos, juntamente com outros que questionam a atitude de diversos atores durante a etapa ditatorial, permitem, em seu conjunto, esclarecer a problemática do consenso. ${ }^{13}$ Entretanto, a limitação dessas perspectivas está no fato de que sua análise só abrange as atitudes, disposições e práticas das cúpulas de cada uma das instituições estudadas, enquanto a conduta das pessoas que não participavam da direção dessas e de outras organizações, as denominadas "pessoas comuns", permanece fora do campo de estudo, fator que desvia o olhar sobre o período e contribui para devolver à maior parte da sociedade uma imagem de tranquilizadora inocência.

13 Nos referimos, entre outros, aos seguintes trabalhos: Groisman (1987), Klich (1989), Bertocchi (1988), Blaustein \& Zuvieta (1998) e Kaufmann (2001). 
Alguns trabalhos acadêmicos aproximaram-se das atitudes de consenso e apoio à ditadura por parte de amplos setores da sociedade. A respeito disso, Vezzetti (2002, p.43) afirmou que "a imagem de uma sociedade majoritária e permanentemente aterrorizada diante de uma violência estendida na vida cotidiana é, basicamente, uma construção retrospectiva" alimentada pela virada "para um ânimo opositor quando a ditadura já estava derrotada". Ao contrário, em sua perspectiva, "uma maioria acompanhou ou levou a sua conformidade às lides da ditadura" (idem, p.42). ${ }^{14}$

Inscrevem-se na mesma linha as reflexões de O'Donnell (1997, p.151), que realizou nos primeiros anos da ditadura uma investigação em que encontrou um alto nível de adesão às mensagens da ditadura entre as pessoas entrevistadas, que, no entanto, negariam ter assumido alguma vez tais posições quando as entrevistas foram reiteradas após a Guerra das Malvinas. ${ }^{15} \mathrm{O}$ 'Donnell afirma que o controle ditatorial sobre as sociedades só pode acontecer devido à existência de "uma sociedade que patrulhou a si mesma", referindo-se a um grupo amplo de pessoas que voluntariamente "se ocuparam ativa e zelosamente de exercer seu próprio pathos autoritário. Foram os kapos que, assumindo os valores de seu (negado) agressor, muitas vezes vemos indo além do que o regime exigia deles" (idem, p.137-8).

Retomando a perspectiva assumida por Vezzetti (2002), fica claro que "o papel e a responsabilidade das "pessoas comuns" não podem ser evitados em um exame das relações entre a ditadura e a sociedade”. O problema

envolve também muitos que tiveram uma participação necessária, mas subordinada, até mesmo subserviente, em funções menores

14 Essa perspectiva coincide com o que foi assinalado pelo jornalista James Neilson (2001, p.15), em maio de 1976, no Buenos Aires Herald: "Muitas pessoas, demasiado respeitáveis, acham que os esquerdistas, sejam eles ativistas que lançam bombas ou idealistas que estão fora do mundo, merecem a pena de morte. Não exigem que isso esteja inscrito no código penal, mas aceitam a morte violenta dos esquerdistas com total equanimidade...".

15 O próprio O’Donnell destacou o caráter informal e pouco sistemático da investigação, determinado pelas condições imperantes naquele momento. 
dentro do aparato estatal, nas Forças Armadas e de segurança e em diversas instituições públicas. Trata-se de considerar e ao mesmo tempo cumprir o papel em muitos casos desempenhado voluntariamente pelos níveis mais baixos de perpetradores e outros colaboradores, alguns obrigados pelo fato de pertencerem às instituições envolvidas na repressão, outros mais livremente dispostos a prestar o seu apoio mediante a delação ou a proclamada adesão e difusão do discurso do regime [...] Provavelmente, nenhum deles poderia ser acusado de condutas criminosas específicas, e no entanto todos eles participaram necessariamente das condições que possibilitaram o desenvolvimento do terrorismo ditatorial. (idem, p.48-9)

Assumir tal perspectiva implica obviamente uma clara distinção entre os níveis de responsabilidade de cada ator, partindo da designação estabelecida pelo próprio autor, no sentido de que falar da responsabilidade das pessoas comuns em situações extremas implica referir-se àqueles que as colocaram nessa situação. Entretanto, tal constatação não implica deixar de formular as perguntas fundamentais acerca das condutas da sociedade:

[...] uma exploração que se pergunte como foi possível o terrorismo de Estado deve ser ampliada para o que aconteceu na sociedade, em suas organizações e em seus dirigentes. Por essa via se chega, necessariamente, aos problemas da responsabilidade coletiva, ou seja, a um plano em que a ação pública da memória excede a denúncia dos crimes, na medida em que a busca da verdade, em relação à sociedade, enfrenta algo distinto da culpabilidade dos criminosos. (idem, p.40)

Vezzetti continua sua exposição distinguindo entre uma culpabilidade criminal, uma culpabilidade política e uma culpabilidade moral, e para isso acompanha a reflexão de Jaspers (1990). Enquanto a primeira não oferece maiores problemas quanto à delimitação das culpas, as restantes implicam a questão da responsabilidade por aquilo que a sociedade promoveu ativamente e até mesmo pelo que foi incapaz de evitar. 
Como é notório, ocultam-se por trás do conjunto dessas posições as dificuldades para sustentar em evidência empírica qualquer dessas afirmações. Os dois olhares abordam aspectos sombrios da vida social, embora o tipo de perspectiva assumida não permita responder algumas perguntas fundamentais: Quem constituía esses grupos? Quais eram suas atribuições de classe, suas identidades políticas, sua distribuição regional? Qual era sua proporção na população?

Investigações recentes tentam responder a essas perguntas a partir de perspectivas microanalíticas ou da história local (Lvovich \& Rodriguez, 2009). ${ }^{16}$ Nelas se conclui que, se às vezes o apoio ou a adesão ao regime surgiu de um entusiasmo militante por suas políticas, postura que foi gerada em redes de sociabilidade política previamente existentes, em outras se deve buscar a explicação em dimensões não expressamente políticas e ideológicas. Assim, no caso das burocracias provinciais e municipais, constatou-se que boa parte dos cargos diretivos foi ocupada por pessoas que, sem pertencer ao regime, encontraram no contexto ditatorial uma oportunidade de ascensão profissional. Nesse sentido, as regularidades da vida burocrática e as pequenas ambições pessoais incidiram sobre a decisão de assumir cargos públicos em um contexto de ditadura, possibilitando assim o funcionamento efetivo das instituições estatais de importância e nível distintos.

Uma dificuldade adicional para a abordagem da problemática do consenso está no fato de as posições dos diferentes atores frente à ditadura terem variado ao longo do tempo em que esta se desenvolveu, ao mesmo tempo em que a avaliação positiva do governo militar não implicou necessariamente a aceitação de cada uma de suas práticas, como demonstra o caso de setores políticos e empresariais que, apesar de apoiarem o regime militar, criticaram duramente suas políticas econômicas. ${ }^{17}$

16 O primeiro estudo regional de envergadura sobre a ditadura e sua implantação social é o de Aguila (2008).

17 Cf. Novaro \& Palermo. op. cit., p.220. 
Outro problema metodológico sério para se enfrentar a problemática do consenso é aquele relativo ao grau de conhecimento social sobre as características e dimensões do terrorismo de Estado, que, sendo maior nas elites políticas, empresariais e eclesiásticas do que no resto da população, aparece como um fator decisivo no momento de aplaudir ou negar apoio ao regime.

Diferentemente de outras ditaduras latino-americanas que submeteram determinadas decisões a plebiscitos - como nos casos do Uruguai e do Chile ${ }^{18}$-, o regime argentino absteve-se de consultar a população por meio de um mecanismo similar. Sendo assim, não contamos com um elemento de julgamento decisivo para a análise dos graus de adesão ou repúdio à ditadura. Isso não impede, no entanto, de considerar - de acordo com o estabelecido por O'Donnell - que da supressão das liberdades e do desenvolvimento da violência estatal podem ter resultado fatores capazes de motivar a adesão de uma parte importante da população.

Esta não resultaria em uma peculiaridade argentina, pois em relação ao nazismo, Kershaw (2000, p.460) chegou à conclusão de que a violência aplicada pelo regime nazista em 1933, longe de prejudicar a reputação de Hitler, favoreceu sua popularidade. $\mathrm{Na}$ mesma direção, Gellatelly (s. d., p.344) defende que a maior parte da população alemã parecia disposta a aceitar a ideia de viver em uma sociedade vigiada e a prescindir do exercício das liberdades em troca de algumas ruas sem delinquência, um retorno à prosperidade e o que considerava como sendo um bom governo.

Esse tipo de interpretação coincide também com a posição de Pilar Calveiro, que indicou que uma das precondições para o estabelecimento da ditadura seria a existência de uma sociedade que houvesse legitimado a tortura. Calveiro (s. d., p.158) nos recorda a simples evidência de que só podem existir campos de concentração em sociedades que "optam por não ver", afirmando que na Argentina a admissão da tortura contra os presos comuns e políticos e da necessidade de exterminar a subversão era amplamente difundida.

18 Cf. Ansaldi (2004, p.43-4). 
Entretanto, Calveiro pinta um quadro matizado, em que o temor ou a cumplicidade social não aparecem como atitudes unívocas, preferindo a autora explicar as condutas como "estranhas combinações de formas de obediência e formas de rebelião" (idem).

Embora a historiografia da ditadura militar ainda esteja em um estado muito inicial de desenvolvimento, e só muito recentemente tenha alcançado plena legitimidade acadêmica na Argentina, as evidências acumuladas permitem afirmar que a ditadura militar instaurada em 1976 está tão distante de resultar em um parêntese inexplicável que não se articula com o desenvolvimento histórico, como de ser um regime totalmente carente de apoios sociais e políticos. Ao contrário, o regime militar começa a ser concebido pelo mainstream historiográfico como um fenômeno articulado com uma longa tradição de autoritarismo e negação dos direitos do adversário, e como a culminação do fenômeno de naturalização da violência e da repressão.

Uma naturalização similar das intervenções militares outorgou legitimidade à ditadura de 1976 perante os olhos de boa parte dos dirigentes políticos, que até muito avançado o Proceso manifestou sua concordância com os fundamentos do regime, apesar de manifestar sua oposição a algumas de suas políticas específicas. Entre o terror e o consentimento, boa parte da sociedade argentina exibiu atitudes sociais que não se diferenciavam daquelas de seus dirigentes políticos, sociais e religiosos, gerando assim condições para que a ditadura se desenvolvesse. Embora a memória predominante em nossos dias não consiga recordá-lo, o regime instaurado em 1976 não estava de modo algum sempre isolado e carente de bases de sustentação sociais e políticas.

\section{Referências bibliográficas}

ACUÑA, C. H.; SMULOVITZ, C. S. Militares en la transición argentina: del gobierno a la subordinación constitucional. In: et al. Juicio, castigos y memórias: Derechos Humanos y justicia en la política argentina. Buenos Aires: Nueva Visión, 1995, p.31-5. 
AGUILA, G. Dictadura, represión y sociedad en Rosário (1976/1983): un estudio sobre la represión y los comportamientos y actitudes sociales en dictadura. Buenos Aires: Prometeo, 2008.

ANSALDI, W. Matriuskas de terror. Algunos elementos para analizar la dictadura argentina dentro de las dictaduras del Cono Sur. In: PUCCIARELLI, A. (Comp.). Empresarios, tecnócratas y militares: la trama corporativa de la última dictadura. Buenos Aires: Siglo XXI, 2004, p.161, p.43-4.

BERTOCCHI, N. B. La cara civil de los golpes de Estado. Buenos Aires: Galerna, 1988.

BIESCAS, J. A.; LARA, M. T. España bajo la dictadura franquista (19391975), Madrid: Labor, 1981.

BLAUSTEIN, E.; ZUVIETA, M. Decíamos ayer: la prensa argentina bajo el Proceso. Buenos Aires: Colihue, 1998.

BOLOGNA, S. Nazismo y clase obrera. Madrid: Akal, 1999.

BOTTI, A. Cielo y dinero: el nacionalcatolicismo en España (1881-1975). Madrid: Alianza, 1992, p.142.

BROWNING, C. Aquellos hombres grises: el batallón 101 y la Solución Final en Polônia. Barcelona: Edhasa, 2002.

CALVEIRO, P. Poder y desaparición: los campos de concentración en la Argentina. Buenos Aires: Colihue, 1998.

COHEN, Y. The manipulation of consent: the State and working - class consciousness in Brazil. s. 1.: University of Pittsburg Press, 1989.

CORRADI, J. El método de destrucción. El terror en la Argentina. In: QUIROGA, H.; TCACH, C. (Comps.). A veinte años del golpe: con memoria democrática. Rosário: Homo Sapiens, 1996, p.89. Publicado originalmente como "The mode of destruction: Terror in Argentina". In: Telos, n. 54, 1982-1983.

DE FELICE, R. Mussolinni Il Duce.I: gli anni del consenso, 1929-1936. Torino: Einaudi, 1974.

DELICH, F. Desmovilización social, reestructuración obrera y cambio sindical. In: WALDMAN, P.; VALDÉS, E. G. El poder militar en la Argentina, 1976-1981. Buenos Aires, Galerna, 1983.

Después del diluvio, la clase obrera. In: ROUQUIÉ, A. (comp.). Argentina hoy. México: Siglo XXI, 1982.

FALCÓN, R. La resistencia obrera a la dictadura militar. In: QUIROGA, H.; TCACH, C. (Comps.), op. cit.; POZZI, P. Oposición obrera a la dictadura (1976-1982). Buenos Aires: Contrapunto, 1988.

FINCHELSTEIN, F. (Ed.). Los alemanes, el holocausto y la culpa colectiva: el Debate Goldhagen. Buenos Aires: Eudeba, 1999. 
GELLATELY, R. No sólo Hitler: la Alemania nazi entre la coacción y el consenso. Barcelona: Crítica, 2002.

GOLDHAGEN, D. J. Los verdugos voluntarios de Hitler: los alemanes corrientes y el holocausto. Madrid: Taurus, 1997.

GENTILE, E. Fascism in italian historiography. In: "Search of an individual historical identity". Journal of Contemporary History, v.21, n.2, abr. 1986.

GROISMAN, E. G. La Corte Suprema durante la dictadura. Buenos Aires: Cisea, 1987.

GUAITINI, G.; SEPPELLI, T. L'organizzazione del consenso del regime fascista: quadro generale. In: NEGRI, G. (Ed.). Política e societá in Italia dal fascismo alla resistenza: problema di storia nazionale e storia umbra. Bologna: Il Mulino, 1978, p.149-50.

JASPERS, K. La culpabilité allemande. Paris: Minuit, 1990.

JOSEPH, G.; NUGENT, D. Everyday forms of state formation: revolution and the negotiation of rule in modern Mexico. Durham; London: Duke University Press, 1994.

KAUfMANN, C. (comp.). Dictadura y Educación. Buenos Aires: Miño \& Dávila, 2001.

KERSHAW, I. 'The Hitler Mith': image and reality in the Third Reich. Oxford: Oxford University Press, 1987, p.4 e 253. . Hitler, 1889-1936. Barcelona: Peninsula, 2000, p.460. La dictadura nazi: problemas y perspectivas de investigación, Buenos Aires: Siglo XXI, 2004, cap.8: “¿Resistencia sin el pueblo?”.

KLICH, I. Políticas comunitarias durante las Juntas Militares argentina : la DAIA durante el Proceso de Reorganización Nacional. In: SENKMAN, L. El antisemitismo en la Argentina. Buenos Aires: Ceal, 1989.

LUZÓN, J. M. L. El estudio de los apoyos sociales del franquismo. Una propuesta metodológica. In: CASTILLO, S. (Coord.). La Historia Social en Espana: actitudes y perspectivas. Madrid: Siglo XXI, 1991.

LVOVICH, D. L. Micropolítica de la dictadura: poder municipal y asociacionismo local, entre la aceptación y el distanciamiento. In: SOPRANO, G.; BOHOSLAVSKY, E. (Eds.). Un Estado con rostro humano: funcionarios e instituciones estatales en Argentina (de 1880 a la actualidad). Buenos Aires: UNGS, 2009

MASON, T. Social Policy in the Third Reich: the working class and the national comunity. Oxford: Berg, 1993.

. Containment of the working class. In: Nazism, fascism and the working class. Cambridge: Cambridge University Press, 1995. 
MIGNONE, E. Iglesia y dictadura: el papel de la iglesia a la luz de sus relaciones con el régimen militar. Buenos Aires: Ediciones del Pensamiento Nacional, 1986.

MOLINERO, C.; YSÁS, P. La historia social de la época franquista. Una aproximación. In: Historia Social, Valencia, n.30, 1998.

NEILSON, J. En tiempos de oscuridad, 1976/1983. Buenos Aires: Emecé, 2001, p.15.

NOVARO, M.; PALERMO, V. La dictadura militar (1976-1983): del golpe de Estado a la restauración democrática. Buenos Aires: Paidós, 2003, p.25.

O’DONNELL, G. Sobre las fructíferas convergencias de las obras de Hirschman, Salida, voz y lealtad y Compromisos cambiantes: reflexiones a partir de la experiencia argentina reciente. In: Contrapuntos: ensayos escogidos sobre autoritarismo y democratización. Buenos Aires: Paidós, 1997, p.151.

. Democracia en la Argentina. Micro y macro. In: Contrapuntos: ensayos escogidos sobre autoritarismo y democratización. Buenos Aires: Paidós, 1997, p.137-8.

PABLO, H. Estado Novo e propaganda em Portugal e no Brasil: o SPN/ SIN e o DIP. Coimbra: Minerva, 1994.

PAINTER, B. W. Renzo De Felice and the historiography of italian fascist. In: The American Historicak Review, v.95, n.2, abr. 1990.

PASSERINI, L. Fascism in popular memory: the cultural experience of the Turin working class. Londres; Paris: Cambridge University Press; Editions de la Maison des Sciences del'Homme, 1987.

PEUKERT, D. Inside nazi Germany: conformity, oposition and racism in everiday life. New Haven: Yale University Press, 1987, p.67.

PUCCIARELLI, A. La patria contratista. El nuevo discurso liberal de la dictadura militar encubre una vieja práctica corporativa. In: (Comp.). Empresarios, tecnócratas y militares: la trama corporativa de la última dictadura. Buenos Aires: Siglo XXI, 2004, p.161.

QUIROGA, H. El tiempo del proceso: conflictos y coincidencias entre políticos y militares, 1976-1983. Rosário: Ross, 1994, p.492.

RICHARDS, M. Un tiempo de silencio: la guerra civil y la cultura de la represión en la España de Franco, 1936-1945. Barcelona: Crítica, 1999, p. 9 e 18.

RODRIGUEZ, L. R. Gobierno municipal, descentralización educativa y funcionarios en la provincia de Buenos Aires durante la dictadura militar. In: SOPRANO, G.; BOHOSLAVSKY, E. (Eds.). Un Estado 
con rostro humano: funcionarios e instituciones estatales en Argentina (de 1880 a la actualidad). Buenos Aires: UNGS, 2009.

ROMERO, L. A. Las raíces de la dictadura. La sociedad como cómplice, partícipe o responsable. In: Puentes, Año I, n.3, mar. 2001.

SÁNCHEZ, I.; ORTIZ, M.; RUIZ, D. (Coords.). España franquista: causa general y actitudes sociales ante la dictadura. s. 1.,Ediciones de la Universidad de Castilla la Mancha, 1993.

SIDICARO, R. El régimen autoritario de 1976: refundación frustrada y contrarrevolución exitosa. In: QUIROGA, H.; TCACH, C. (Comps.). A veinte años del golpe: con memoria democrática. Rosário: Homo Sapiens, 1996, p.21.

TCACH, C. Radicalismo y dictadura (1976-1983). In: QUIROGA, H.; (Comps.), s. d., p.34.

TORGAL, L. Historia e ideología. Coimbra: Minerva, 1994.

VÁZQUEZ, E. PRN. La última: origen, apogeo y caída de la dictadura militar. Buenos Aires: Eudeba, 1984, p.264-69.

VEZZETTI, H. Pasado y presente: guerra, dictadura y sociedad en la Argentina, Buenos Aires: Siglo XXI, 2002, p.88-9.

VICENTE, C. C. El concepto de consenso y su aplicación al estudio del régimen franquista. In: Spagna Contemporánea, n.7, p, 144, 1995.

YANUZZI, M. de los Á. Política y dictadura. Rosário: Fundación Ross, 1996. 


\section{9 \\ A OPOSIÇÃO DE DIREITA AO POPULISMO NO CONE SUL: PROPOSTA PARA UMA HISTÓRIA LATINO-AMERICANA E COMPARATIVA ${ }^{1}$}

Ernesto Bohoslavsky ${ }^{2}$

Estas linhas pretendem criar um instrumental teórico e metodológico com o qual se possa percorrer de maneira comparativa certas experiências e crenças políticas na Argentina, no Brasil e no Chile de meados do século XX. O que aqui se apresentará tem mais a forma de uma declaração de intenções do que de uma exposição de resultados de pesquisa e acredito que possa ser lido como um convite para pensar comparativa e coletivamente sobre como enfrentar o estudo de alguns problemas historiográficos comuns.

As experiências populistas receberam uma grande atenção historiográfica na América Latina. Os governos de Perón, na Argentina, de Ibáñez, no Chile, e de Vargas, assim como os discursos de figuras populistas como Jorge Eliécer Gaitán, Victor Raúl Haya de la Torre e Paz Estenssoro, foram estudados em suas diversas dimensões: sua política social, seu vínculo político com as maiorias

1 Tradução de André Lopes Ferreira.

2 Doutor em História e professor da Universidade Nacional de General Sarmiento, é autor de El compot patagónico. Nación, conspiracionismo y violencia en el sur de Argentina y Chile (siglos XIX y XX). Buenos Aires: Prometeo, 2009, e coeditor de El hilo rojo. Buenos Aires: Paidós, 2008 e Instituciones y formas de control social en América Latina, 1840-1940. Uma revisión. Neuquén: Universidad Nacional de la Pampa, 2006. 
populares, suas estratégias econômicas e seu impacto em termos de institucionalidade democrática e das identidades políticas. Sobre todas essas pesquisas, surgidas quase contemporaneamente aos processos de ascensão ao poder dos populismos em meados do século XX, pode-se assinalar que não conseguiram - e seria difícil supor que conseguissem - chegar a acordos significativos e duradouros sobre o significado do termo populismo, inclusive sobre a pertinência ou utilidade de continuar utilizando-se dele.

Outro dos traços da preocupação continental com essas experiências é o desinteresse pela natureza das oposições político-partidárias ao populismo, cujas causas parecem ser várias. Entre elas poderia-se mencionar certa naturalização da oposição ao populismo, entendida quase como uma obrigação, um imperativo ético, que não exigiria, em consequência, muita explicação ou revisão historiográfica. Sendo conhecida a pronunciada antipatia dos intelectuais pelo populismo na década de 1950, de alguma maneira suas posições fizeram eco e foram validadas posteriormente pelas Ciências Sociais. Outra causa é a força histórica da agenda reformista do populismo e de seu discurso, que, vistos em perspectiva, pareciam ofuscar as ideias e as práticas políticas dos grupos opositores, as quais eram vistas principalmente como reações frente ao único sujeito histórico relevante. Daí que ainda falte uma historiográfica sistemática sobre as oposições de esquerda e de direita aos governos populistas que permita conhecer mais de perto as reações e os diagnósticos apresentados por esses grupos.

A minha proposta consiste justamente em abordar a história das oposições de direita aos regimes populistas da Argentina, do Brasil e do Chile $e^{3}$ nas décadas de 1940 e 1950. Contudo pretende-se realizar essa incursão a partir de uma perspectiva que não é a da história nacional, mas a da historiografia latino-americana, isto é, por meio da estratégia comparativa e não da metodologia tradicional de análise da história política. Por que latino-americana e por que comparativa? O que pode ser visto? Quais podem ser as variáveis relevantes para esta pesquisa?

3 Doravante denominados como ABC (N. do T.). 


\section{Uma historiografia latino-americana}

Tanto os populistas quanto seus inimigos tinham um horizonte político e simbólico que ultrapassava as referências nacionais. Está claro que esse horizonte achava-se repleto de tradições, leituras e simbologia de origem europeia, dentre as quais as provenientes da disputa entre fascismo e democracia ocupavam um lugar preponderante e quase exclusivo. No entanto, os atores também recorriam a um horizonte latino-americano do qual lançavam mão tanto para compreender o andamento dos seus países como para legitimar suas posições e criticar as de seus adversários políticos. Assim, os argentinos puderam perceber em Perón o Vargas argentino, e os chilenos não deixaram de apontar as semelhanças entre os estilos do "Primeiro trabalhador" argentino e o do general Carlos Ibáñez del Campo. Os líderes populistas vinculavam-se entre si por meio de acordos comerciais ou políticos, imitavam-se e desconfiavam uns dos outros de acordo com o poder relativo de cada um e de suas relações com as potências centrais. Porém entendo que para muitos opositores, esse horizonte de referências latino-americanas também atuava como um marco a partir do qual se podia interpretar o que acontecia nos espaços nacionais e no continente, quais estratégias de desgaste haviam sido úteis e quais haviam se tornado inviáveis.

Por outro lado, as políticas econômicas levadas adiante pelos governos populistas atestam a contemporaneidade de certos problemas e restrições no crescimento dos países do Cone Sul. Entre eles, ocupava um lugar destacado a promoção estatal de manufaturas e a indústria pesada, a incorporação dos trabalhadores e suas famílias ao mercado interno, a tensão quanto aos investimentos estrangeiros e quanto aos grupos de pressão, e os interesses de industriais, latifundiários e sindicatos. Quer dizer, trata-se de um conjunto de problemas que, sem ser exclusivos da América Latina no segundo pós-guerra, cobria boa parte das preocupações e projetos dos partidos políticos deste continente após a ruptura definitiva da ordem econômica e política agroexportadora. 
Uma abordagem latino-americana de diferentes casos nacionais oferece a vantagem adicional de permitir uma nova discussão a respeito do fenômeno da circulação, transformação e apropriação de ideias no século XX. Dado que os países do Cone Sul foram vigorosos consumidores de ideologias produzidas fora de seu entorno geográfico, é possível perceber processos de importação de correntes de ideias. Atualmente já se sabe que importação não equivale a adoção pura e simples, mas sim a adaptação e uso seletivo. Daí que nos perguntemos sobre os mecanismos e atores envolvidos na aceitação, na modificação e no recorte de ideias de alcance ocidental no ABC. Por exemplo, qual foi o impacto em âmbito nacional das decisões do Vaticano no início da década de 1950 de orientar os paroquianos a uma maior participação política, inclusive com um partido democrata cristão? E a aceitação, tardia, por certo, da democracia como regime por Pio XII, em detrimento de outras formas de organização da vida política? O que aconteceu com as direitas do ABC e a convocatória de Washington para uma cruzada continental anticomunista?

De alguma maneira evidente, mas difícil de estudar e calcular, a recepção das ideias provenientes da Europa Ocidental e dos Estados Unidos obedecia a distintas razões, entre as quais há que se apontar, em primeiro lugar, a utilidade que essas ideias concediam a quem as introduzia no país. Alinhar as ideias e os partidos políticos da América Latina a estruturas e correntes ideológicas inovadoras ou com certo prestígio oferecia chances de legitimar essas posturas na confrontação com os regimes populistas. Mas além dessas razões utilitárias, entendo que existem outras, menos racionais do ponto de vista dos atores da época. Refiro-me, por exemplo, ao peso identitário que pode ter a vinculação com ideias provenientes de âmbitos extranacionais, levando a preferir certas correntes em detrimento de outras aparentemente mais coerentes com as sustentadas localmente. Isso relembra que é inevitável levar em conta o caráter histórico da construção dos grupos políticos, de seus militantes e de seus líderes: as tradições às vezes facilitam a entrada e adoção de ideias, símbolos, publicações, intelectuais e inclu- 
sive de pessoas exiladas. Todavia, simultaneamente, essas tradições e configurações identitárias inibiam ou dificultavam a chegada e a apropriação das ideologias que vinham do norte.

\section{Uma historiografia comparativa}

A necessidade dos trabalhos comparativos tem sido muito mais assinalada do que praticada ao longo do tempo. Paradoxalmente, foi antes um traço dos Latin American Studies, e não dos historiadores latinoamericanos. Os intelectuais situados nas instituições europeias e norte-americanas recorrem com muita assiduidade e eficácia ao registro comparativo, o qual lhes permite oferecer um olhar de conjunto sobre a história do continente. Esse enfoque, em boa medida, sustenta-se na convicção de que todos os países que compõem a América Latina têm algo em comum que permite ensaiar explicações gerais e de validade quase universal. Em contrapartida, nós, historiadores latino-americanos, tendemos a nos concentrar na história nacional e a descobrir e exaltar sua particularidade. Realizamos muito poucas incursões em terras vizinhas, em geral com o estreito propósito de estender a outros territórios e tempos, de maneira imperialista, a periodização que é útil para nosso país de origem.

Por que postulamos a necessidade de uma proposta comparativa? O que queremos dizer com uma proposta comparativa? Talvez fosse mais simples dizer o que não queremos fazer. Não se trata de acumular histórias nacionais e de colocá-las umas junto às outras, Ou seja, não é uma questão de somar distintos estudos de caso ou de tipos de um fenômeno abrangente, para que apareça uma verdade "geral" e abstrata comum a todas as situações, de modo que não sejam tidas como anormais. Considero a estratégia comparativa como aquela que permite observar um ou vários casos, à luz de um terceiro. Isto é, não vejo a estratégia da história comparativa como algo destinado a contar o que aconteceu, quem atuou ou o que disse, e sim como uma possibilidade que permite compreender por que 
tal experiência foi diferente de outra, por que não houve isso ou aquilo. Essa estratégia traz implícita uma natureza desconstrutiva, dado que desnaturaliza aquilo que um sistema educacional e uma historiografia centrada no espaço nacional naturalizaram. A comparação introduz de maneira irreversível a indagação sobre por que tal coisa ocorreu aqui e não ali; por que o catolicismo apareceu como um ponto de união da oposição ao peronismo em 1955 e o mesmo não aconteceu no Chile; por que a fratura territorial foi relevante no momento de articular a oposição a Vargas nas décadas de 1930 e 1950, mas não foi assim na Argentina e nem no Chile.

Retomemos esse ponto para recordar a utilidade do método comparativo. A oposição ao peronismo, entre 1943 e 1955, ou ao governo de Ibáñez, entre 1952 e 1958, foi protagonizada por partidos políticos, corporações empresariais e meios de imprensa. O que se pode ver ali é, por um lado, uma disputa entre os partidos que ficaram fora do Poder Executivo e um regime político que se impôs no país, e, por outro lado, tensas lutas entre classes e frações de classe. Agora, se olharmos o caso do Brasil, salta à vista a profundidade da fratura territorial que gerou o processo político entre 1930 e 1964. De fato, o golpe de 1930 pode ser lido como a violenta imposição de um novo acordo político territorial, que vinha a substituir a política do café com leite. Diante da nova configuração territorial, o governo federal passou a ocupar um lugar preponderante frente aos Estados, que se enfraqueceram em sua capacidade institucional e seus níveis de autonomia. Entre as unidades da federação, o estado de São Paulo - até então dominante - foi o mais prejudicado, dado que perdeu o controle de um poder executivo nacional que lhe tinha sido muito próximo e dócil. Outros Estados, como Minas Gerais e Rio Grande do Sul, conseguiram reposicionar-se de maneira mais exitosa no âmbito federal. Isso significa que a oposição aos governos de Getúlio Vargas - tanto o que resultou do golpe de 1930 como o do mandato constitucional de 1934 ou durante o Estado Novo teve um conteúdo não apenas político, mas também territorial.

Em 1932, a elite paulista encabeçou a Revolução Constitucionalista com o objetivo de derrotar Vargas e, na medida do possível, 
restaurar a ordem da Republica Velha. Nos anos seguintes, a emergência do Estado Novo foi vista por muitos membros das antigas elites como uma versão tropical do fascismo, diagnóstico que se viu reforçado em vista dos fluidos contatos do Brasil com as potências do Eixo. Nesse contexto, algumas elites não só se tornaram aliadófilas durante a Segunda Guerra, mas também a favor da democracia. A democracia liberal tradicional, encarnada na constituição abolida em 1934, afigurou-se como um valor positivo a ser defendido em contraste com o varguismo e depois em relação ao comunismo. Esta perspectiva, que se manteve vigente inclusive na década de 1950, quando a democracia estava em funcionamento (Donato, 2002), teve um significado fundamental para compreender como a UDN articulou-se ao sistema político durante os vinte anos posteriores à queda do Estado Novo (Bohoslavsky \& Morresi, 2008).

$\mathrm{Na}$ Argentina e no Chile, ao contrário, a dimensão territorial da política não teve maiores desdobramentos no interior da díade populismo/antipopulismo, embora em algumas regiões fosse possível detectar uma oposição mais forte, como no caso da cidade de Buenos Aires ou da província de Córdoba. Durante a década de 1950 não havia nos dois países nenhuma disputa entre as elites em matéria de distribuição territorial do poder: não passava pela cabeça de qualquer agrupação política relevante a criação de uma ordem territorial que, de fato, pudesse repousar em algo que não fosse a primazia absoluta das áreas metropolitanas de ambos os países. Dessa maneira, uma abordagem comparativa estabelece um conjunto de perguntas acerca das diferenças: a ausência e a profundidade das fraturas territoriais não podem passar despercebidas, exigindo uma maior preocupação analítica.

\section{Construção, co-construção e espelhos}

Gostaria de frisar, também, a necessidade de prestar atenção nas disputas, divisões e tensões existentes entre os grupos antipopulistas. A dimensão negativa de sua identidade, quer dizer, sua 
oposição ao regime populista, não deve levar a que se apaguem as diferenças e receios que existiam entre esses grupos. Fazer isso implicaria em assumir como válido o argumento populista que tende a dividir o espectro ideológico entre os guardiões dos interesses nacionais e populares (ou seja, eles próprios) e os que por motivos inconfessáveis se opõem a isso (o mesmo ocorre se são comunistas ou liberais). Liberais e conservadores chilenos eram opositores ao governo de Ibáñez e o criticavam duramente, mas nem por isso unificaram suas candidaturas ao legislativo ou estavam de acordo quanto ao tipo de regime que deveria suplantar o orientado pelo velho general. Não é suficiente dizer que certo partido ou corrente de ideias é antiperonista ou antigetulista, há que se saber de qual antiperonismo ou antigetulismo estamos falando. Isso significa assumir o caráter não essencialista das identidades políticas e destacar, pelo contrário, o peso das contingências, dos interesses concretos e das oportunidades políticas.

Talvez seja mais simples compreender a diversidade do campo antipopulista se atentarmos para o fato de que as identidades políticas não são produzidas de uma vez para sempre, mas estão submetidas a um processo permanente de transformação e confirmação. Nesse processo intervêm vários fatores, entre os quais não se pode esquecer a força que tem a própria identidade populista, seu estilo de mobilização política, sua retórica e sua agenda. Assim como os opositores do populismo definiram sua agenda e autoimagem em função do regime dominante, eles também moldaram suas posturas ideológicas e seus estilos de comunicação e mobilização tendo como referência os outros partidos e organizações de oposição com os quais competiam. Com efeito, a deserção ou o desaparecimento de um partido político opositor ao populismo poderiam ser vistos como uma vitória desse regime, mas também como uma vitória de outros grupos opositores, convencidos a beneficiar-se com esse caudal de votos, que ficava, por assim dizer, disponível. Contudo, deve-se lembrar também que o populismo moldou determinada parte de seu discurso em função das atitudes e estratégias definidas por seus opositores. As iniciativas parlamentares da oposição, sua 
capacidade de mobilização popular, suas denúncias, foram também fonte de alimentação para o imaginário populista e suas práticas políticas (García Sebastiani, 2005).

\section{O que observar?}

A hipótese que defendemos recentemente (Bohoslavsky \& Morresi, 2008) postula que, para analisar a relação entre os partidos de direita e o jogo democrático é necessário observar, pelo menos, duas variáveis: a forma de imaginar-se e imaginar os outros, e a relação com as forças armadas. No momento de se autorrepresentar, os grupos políticos excluem de seu vocabulário político as ideias ou conceitos que não podem assimilar, que são difíceis de manusear ou que estão inevitavelmente identificados com seus adversários (Campbell, 2001; Lakoff \& Johnson, 2003). O que fica de fora varia de país a país: na Argentina era o "populismo" (vagamente definido, mas que se referia à demagogia, ao gasto público excessivo, ao desprezo à ordem institucional e à sensibilidade excessiva diante das pressões sociais e corporativas), no Brasil era o varguismo (entendido como uma via totalitária que sufocava as forças dinâmicas do capitalismo local). No Chile, o conceito excluído era o autoritarismo. O país foi um dos poucos nos quais as reformas sociais de certa envergadura puderam desenvolver-se dentro de instituições democráticas (Buchrucker, 2003). A debilidade dos discursos e agrupações nacionalistas e antiliberais é uma das razões para que se constituísse um regime político ao mesmo tempo democrático, competitivo e com a capacidade de incidir na sociedade.

Em relação aos valores assumidos como próprios, a direita liberal argentina promovia a república, e não a democracia (Morresi, 2007; 2008). A direita chilena, ao contrário, tinha na democracia um de seus conceitos mais caros, posto que isso lhe permitia diferenciar-se da via socialista ao "totalitarismo soviético". Por sua parte, os brasileiros valorizavam a modernização, o que coincide com a hipótese desenvolvida por José Luis Beired a respeito dos 
grupos de direita na década de 1940: os argentinos consideravam que sua nação fora consolidada no passado, mas seu destino havia sido desviado e degenerado devido à ação de conspirações. Seus pares brasileiros, em contrapartida, insistiam que a nação ainda deveria ser formada, o que seria o resultado lógico e contínuo de sua evolução histórica (Beired, 1999). Argentinos e chilenos olhavam para trás em busca de restauração, ao passo que os brasileiros acreditavam encontrar o melhor no futuro.

A segunda variável relevante a se considerar é a percepção que a direita antipopulista tinha o respeito das forças armadas. Mesmo que essa caracterização sobre o papel do Exército tenha se produzido nas décadas de 1920 e 1930, essa forma de imaginá-lo tornou-se uma guia constante que não se modificou muito até a última restauração democrática na qual estamos vivendo. Assim, os temores ante a presença de uma tendência reformista nos meios militares (no caso do Chile e do Brasil) ou a convicção de sua completa ausência ou impotência política (no caso argentino) apresentaram-se como elementos da percepção dos grupos direitistas, que foram levados em consideração no momento de ponderar sobre a legitimidade e a viabilidade do jogo democrático-eleitoral.

As elites de São Paulo e do Rio de Janeiro advertiam, já na década de 1920, que o reformismo social tinha forte presença entre a oficialidade militar: de fato, o movimento tenentista parecia dialogar melhor com algumas propostas do Partido Comunista do que com o Partido Republicano Paulista. No Chile, nesses mesmos anos a elite convenceu-se de que não podia contar com o respaldo automático das forças armadas para assegurar suas posições. Em 1924, um levante militar exigiu do Parlamento a aprovação da legislação trabalhista. Em 1932, alguns membros da corporação armada participaram do golpe de Estado que instituiu uma "República socialista" que durou poucos dias, e um dos chefes da Aeronáutica converteu-se, nesse ano, no fundador do Partido Socialista (Correa Sutil, 1989). Por isso boa parte da identidade da direita era civilista, enquanto o Exército baseou-se no princípio do afastamento da vida política e na fidelidade ao presidente da República. Apenas assim 
pode-se compreender que o Chile tenha sido o único caso na América Latina de vitória pacífica de um presidente com um programa de esquerda radical em 1970 (idem, 2005).

Em relação ao Exército argentino, tomado comparativamente a partir dos exemplos brasileiro e chileno, evidencia-se a debilidade de uma corrente de reforma social, ou, em todo caso, sua escassa vinculação com o pensamento democrático. Erigido mais como protetor da restauração do que modernizador, para ele se dirige a atenção daqueles que buscam encontrar as causas das enormes diferenças entre a ditadura argentina e a brasileira.

\section{Referências bibliográficas}

BEIRED, J. L. B. Sob o signo da nova ordem: intelectuais autoritários no Brasil e na Argentina, 1914-1945. São Paulo: Edições Loyola, 1999.

BOHOSLAVSKY, E.; MORRESI, S. D. Tradiciones derechistas y democracia en Argentina, Brasil y Chile en la segunda mitad del siglo XX. In: II Jornadas de Estudios Políticos "La política en la Argentina actual: nuevas formas de pensar viejos problemas". Universidad Nacional de General Sarmiento, 12 y 13 nov. 2008.

BUCHRUCKER, C. Identidades nacionales y cultura política antidemocrática. Trayectorias históricas del Cono Sur en el siglo XX. In: Congreso "La construcción de las identidades nacionales en el mundo hispánico". Universidad de Valencia, 2003.

CAMPBELL, J. L. Institutional analysis and the role of ideas in political economy. In:___ PEDERSEN, O. K. (eds.). The rise of neoliberalism and institutional analysis. Princeton: Princeton University Press, 2001, p.159-89.

CORREA SUTIL, S. La derecha en Chile contemporáneo: la pérdida del control estatal. Revista de Ciencia Política, Santiago, 11(1), 1989.

. Con las riendas del poder: la derecha chilena en el siglo XX. Santiago: Editorial Sudamericana, 2005.

DONATO, H. História da Revolucão Constitucionalista de 1932: comemorando os 70 anos do evento. São Paulo: Ibrasa, 2002.

GARCÍA SEBASTIANI, M. Los antiperonistas en la Argentina peronista: radicales y socialistas en la política argentina entre 1943 y 1951. Buenos Aires: Prometeo Libros, 2005. 
LAKOFF, G.; JOHNSON, M. Metaphors we live by. Chicago: University of Chicago Press, 2003.

MORRESI, S. D. La democracia de los muertos. Algunos apuntes sobre el liberalismo-conservador, el neoliberalismo y la ideología del Proceso de Reorganización Nacional. In: XI Jornadas Interescuelas de Historia, Tucumán, 19-21 sept. 2007.

Neoliberales antes del Neoliberalismo. In: SOPRANO, G.; FREDERIC, S. (eds.). Política y variaciones de escala en el analisis de la Argentina. Buenos Aires: Prometeo, 2009. 


\section{0 \\ Argentina e Brasil \\ EM MARCHA PARA A INTEGRAÇÃO \\ (1950-1962)}

Iuri Cavlak ${ }^{1}$

Na história da política externa brasileira, alguns períodos podem ser caracterizados como ortodoxos. Por exemplo, a diplomacia praticada após a independência política de 1822, quando a classe dirigente utilizou-se do Estado para comprometer o país no pagamento das dívidas junto à Inglaterra, oriundas da época colonial e que foram assumidas por D. Pedro II visando a proteção britânica para que o país não voltasse ao domínio português e não fosse molestado por outras nações europeias (Cervo et al., 2002, p.17-40), além da diplomacia da "agroexportação" efetivada na primeira década do século XX, em que o Estado respondeu às demandas diretas da classe dominante de então, os grandes plantadores de café (Bueno, 2003, p.91-110).

Neste artigo, analisamos um período em que a política externa brasileira não esteve diretamente vinculada à política agrário-exportadora, senão às novas necessidades criadas no bojo do processo de industrialização. Após o crash de 1929, o período da Grande Depressão e a Segunda Guerra Mundial, as relações internacionais na América do Sul foram redefinidas por seus dois maiores países, Argentina e Brasil, que desenvolveram uma fase de aproximação

1 Doutor em História e autor de A política externa brasileira e a Argentina peronista. São Paulo: Annablume, 2008. 
diplomática com o intuito de barganhar melhores condições de investimentos com os Estados Unidos e maiores preços para suas exportações. Conforme o projeto industrializante concebido por ambos, a massa de recursos só poderia vir do estrangeiro, daí a implementação de uma política externa heterodoxa, que questionou em parte a lógica das trocas internacionais e discutiu nos fóruns das Nações Unidas uma nova configuração política, no intuito de viabilizar um maciço aporte de capitais norte-americanos para a formação de um sólido parque industrial no subcontinente.

Além disso, no pós-guerra, alguns setores sociais, tanto na esfera interna quanto na esfera externa, passaram a reivindicar algum tipo de união política entre Argentina e Brasil: no primeiro lustro dos anos 1950, o movimento peronista e os diplomatas e políticos mais próximos a Getúlio Vargas; posteriormente, a União Cívica Radical Intransigente e o presidente argentino Arturo Frondizi, bem como a classe dirigente brasileira e Juscelino Kubitschek, na estratégia de implementação da Operação Pan-Americana (OPA). Exteriormente, a Comissão Econômica para a América Latina (Cepal), órgão das Nações Unidas, diagnosticou a falta de uma integração econômica dos países da região como um dos entraves ao desenvolvimento, em contraste com o processo que já vinha se desenhando na Europa. Em função disso, a Cepal produziu diversos textos e relatórios vaticinando pela criação de uma zona de livre comércio sul-americana, munindo ideologicamente os setores sociais argentinos e brasileiros que apostavam na barganha com Washington para que seus países se desenvolvessem.

A formação da Associação Latino Americana de Livre Comércio (Alalc), em 1960, foi diretamente devedora da aproximação dessas duas nações, que tentaram a formação de uma hegemonia dual no subcontinente, construída ao longo da década e desarticulada politicamente pelos golpes militares na Argentina, em 1962, e no Brasil, em 1964.

Isso tudo ocorreu em um momento em que se viram ofuscadas as assimetrias de poder que sempre envolveram a diplomacia entre Buenos Aires e Rio de Janeiro. No período de 1880 até 1930, o 
desenvolvimento econômico e o poder militar da Argentina foram superiores aos brasileiros. Após a segunda metade dos anos 1960 e a década de 1990, o Brasil abriu grande vantagem. Entre 1950 e 1962, a capacidade econômica e a força bélica de ambos mantiveram-se em um patamar semelhante, contribuindo para o afrouxamento das desconfianças e o lançamento das iniciativas de integração.

Assim, analisaremos as principais conjunturas em que Argentina e Brasil voltaram-se para a aproximação econômica e política, mediante o exame de documentos gerados nos dois países pelos seus órgãos diplomáticos. No caso da Argentina, pesquisamos as fontes do Arquivo do Ministério das Relações Exteriores, Comércio Internacional e Culto da Argentina, além do arquivo de Arturo Frondizi, localizado na Biblioteca Nacional, em Buenos Aires. As fontes brasileiras foram levantadas no Arquivo Histórico do Itamaraty, no Rio de Janeiro, e no Arquivo do Ministério de Relações Exteriores, em Brasília.

\section{A primeira metade dos anos 1950}

Era essencial para o projeto de inserção internacional da Argentina peronista a vitória de Getúlio Vargas nas eleições presidenciais brasileiras de 1950. Por conta disso, Perón ajudou financeiramente a campanha de Vargas, oferecendo inclusive auxílio militar caso as forças armadas não aceitassem sua consagração nas urnas (Almeida, 2005, p.23-45). Uma vez eleito, várias listas comerciais foram estabelecidas com a Argentina, potencializando a troca de mercadorias e, com efeito, articulando novos compromissos na esfera econômica. Em parceria com o Chile, onde o aliado de Perón, general Carlos Ibañez del Campo, vencera as eleições presidenciais de 1952, buscou-se a formulação do Pacto ABC, das iniciais dos três países, para o planejamento das respectivas economias e o fortalecimento da aliança política em oposição aos Estados Unidos.

Durante esse mesmo ano, bateu recorde o número de viagens de turistas culturais brasileiros a Buenos Aires com todas as despesas 
pagas pelo governo argentino. Sindicalistas, estudantes do Ensino Secundário e Superior e grupos de teatro a todo momento desfrutaram dessa prática. No sistema de ensino argentino, foi criado o "Prêmio Brasil", contemplando mensalmente com uma viajem a São Paulo os alunos que realizassem a melhor dissertação sobre um tema da história do Brasil. ${ }^{2}$ Ainda em dezembro de 1952, ambos assinaram um acordo comercial de grande porte, para entrar em vigor em janeiro de 1953, com validade prevista até 31 de dezembro de 1956, em caráter provisório, até obter aprovação dos respectivos parlamentos. Os principais produtos negociados foram:

Productos Argentinos: valor Cr $\$ 1.000$. Trigo (700 mil toneladas, 1.500.000), avena para consumo y forrajera (8.3000), alpiste e otros cereales para alimentación de pájaros (2.4000), carne vacuna congelada (agosto a diciembre de 1953, 10.000), harina de carne, tripas, lenguas, embutidos, etc (15.000), animales para reproducción (43.000), aves para consumo (5.000), harina y guao de pescado (10.000), forrajes em general (5.000), lanas en bruto (8.000), manteca (septiembre a diciembre de 1953, 12.800), medicamentos (2.500), ácido tartárico (10.000), libros, revistas y música impresa (6.000), aceite de oliva (11.000), leche en polvo (3.000), quesos (1.000), vinos (7.000), lámparas fluorescentes y bobinas para radio frecuencia (30.000), varios (cueros curtidos y sus manufacturas, derivados del maiz, otros subproductos ganaderos, legumbres y hortalizas (15.000). Total: 1.818.750.

Productos brasileños: cacao (125.000), café (555.000), lingotes para fundición (63.000), aleaciones para fundición (8.100), maderas (632.000), maderas de cedro (37.000), casdos o toneles de madera (27.000), duelas para cascos (6.500), palos para escobas (2.500), pita en rama (33.000), bloks (3.500), ladrillos (5.500), materiales sintéti$\cos$ (15.000), bauxita (2.200). Total : $1.727 .000 .^{3}$

2 Ofício "mês político e cultural" de dezembro de 1952. "Balanço dos acontecimentos do ano".

3 Nota reversal, dezembro de 1952. 
Em troca de mais carne bovina congelada, destinada ao consumo interno brasileiro, os argentinos gostariam de importar "hilo de algodón para bordar, hilo de algodón para el telar, té, tejidos de algodón y artículos de cauchos." (idem) Estabeleceu-se uma contaconvênio, com o compromisso entre ambas as partes de ajustarem déficits e superávits todo final de semestre, de modo a alcançar o menor desequilíbrio possível. Em outro documento, a missão econômica brasileira, que se encontrava em Buenos Aires para fechar esse acordo, realizou várias ponderações visando a aumentar as vantagens econômicas brasileiras, dentro do que se imaginava aceitável para os argentinos. ${ }^{4}$

Do ponto de vista estritamente político, o governo argentino acreditava no desempenho de João Goulart para a concretização política do ABC, uma vez tratar-se do quadro mais próximo de Vargas, que fora incumbido de ser o mediador brasileiro desse pacto. De acordo com a Embaixada Argentina no Rio de Janeiro:

Desde el primer momento, João Goulart trató de organizar sindicalmente a los trabajadores agrupándoles en gremios, bajo el control y dirección de una organización superior, similar a la CGT argentina, a la que pudo conocer y verificar sus resultados personalmente en los viajes que realizó a nuestro país antes de su designación como ministro. Estas reformas que Goulart trató de llevar a la práctica, hace que la prensa brasileña desatara en su contra una furibunda campaña, tildándolo de peronista. [...] En varias oportunidades, Goulart se expresó como entusiasta admirador de la personalidad del General Perón y su doctrina justicialista. ${ }^{5}$

A confiança era tanta que vaticinou o serviço diplomático argentino:

4 Missão Econômica Brasileira na Argentina, ofício de 6 de dezembro de 1952.

5 Caja Brasil: Informe Particular Sobre Ministro del Trabajo del Brasil, Señor Joao Goulart. Síntesis de Sus Antecedentes y Actividades Actuales (dezembro de 1953). 
Tanto las criticas como las expresiones favorables han hecho que el ministro del trabajo, que hasta el año de 45 era prácticamente desconocido como figura política, se tornara en una figura de preponderancia en la vida política-económica del Brasil, mencionando-se su nombre cada día con mayor apoyo del proletariado brasileño como futuro candidato a la presidencia de la nacion en las elecciones a realizarse en el año de 1954 [um erro de grafia talvez, pois as eleições presidenciais no Brasil estavam marcadas para 1955. (ibidem)

O que fazia de Goulart figura importante desse ponto de vista era a estrutura socioeconômica brasileira.

La existencia en Brasil de una clase "alta y privilegiada" y de otra "paria" y con standard de vida miserable, ha hecho posible el surgimiento de un hombre como Joao Goulart, que trata de establecer el equilibrio social para que la nación pueda ventilar sus problemas internos y externos en la seguridad de que el pueblo feliz sabrá mantener sus posiciones con dignidad, no permitiendo jamás la intromisión de intereses foráneos que perturben su felicidad [...] El mejoramiento evidente de las relaciones Argentino-Norteamericanas y el ejemplo dado por nuestro país manteniendo incólume su soberanía política y social, hacen que el pueblo brasileño vea en la persona de su actual ministro del Trabajo un émulo del General Perón, y el hombre en el cual pueden cifrar sus reivindicaciones sociales y por lo tanto hacer que el señor Goulart, sin el apoyo de ningún partido político se encuentra en la actualidad en óptimas condiciones para ser candidato a la presidencia de la nación. (ibidem)

Posteriormente, comentou-se que Vargas havia sido pressionado pelas "forças econômicas" a barrar a política trabalhista de Goulart e afastá-lo temporariamente do Ministério do Trabalho. $\mathrm{Na}$ visão da diplomacia argentina, o presidente brasileiro aceitou o pedido de demissão de Goulart esperando que uma "reação popular" reconduzisse o ex-ministro de volta ao cargo. O fato de isso não 
ter ocorrido dever-se-ia à "apatia do povo brasileiro", que ainda "não era dono de seu destino". ${ }^{6}$

Junto a isso, a Embaixada Argentina entendia que cada vez mais as concepções peronistas estavam sendo colocadas em prática na sociedade brasileira.

La otra influencia importante en el Brasil es la procedente de la Republica Argentina. Ella comienza, en el campo económico, por el abundante intercambio de cereales nuestros y de café, maderas, etcétera por parte del Brasil. Pero el orden fundamental es el político. La rápida y acertada evolución argentina en materia social, a causa de la labor de Gobierno del Excmo. Señor Presidente Juan Perón ha tenido aquí, a pesar de la ignorancia generalizada y del analfabetismo que impiden los adecuados conocimientos de los ideales de justicia social un rápido desenvolvimiento. (ibidem)

Ainda durante o ano de 1953, fora combinada a visita de Perón ao Brasil para o dia 7 de setembro, data em que se faria pública a união política. ${ }^{7}$ Por meio de gestões de Goulart e do embaixador brasileiro em Buenos Aires, João Batista Lusardo, fora acertado que Argentina e Brasil votariam em conformidade nos pleitos da Organização dos Estados Americanos (OEA), aumentariam progressivamente o comércio mútuo de produtos manufaturados e assumiriam um projeto de defesa do Atlântico Sul (Santos, 191, p.62-3). No Chile, publicamente Perón confirmou esses acordos, dizendo que Vargas só esperava melhorar sua sustentação política interna para fazer valer essa política diplomática. ${ }^{8}$

Em junho de 1954, a Comissão Mista de Comércio de Brasil e Argentina assinou novos acordos, em regime especial de preços,

6 Notas de la Embajada Argentina no Brasil. Mayo-Junio de 1954.

7 Essa e mais três visitas acertadas de Perón ao Brasil ao longo do período não se concretizaram. Vargas e Perón jamais se encontrariam pessoalmente.

8 América del Sur (1950-1980). Embajada de la República Argentina en Brasil. Nota de 23 de março de 1953. 
que envolviam a compra de 700 mil toneladas de trigo, 25 mil toneladas de farinha de trigo e uma quantidade não divulgada de carne argentina por parte do Brasil, e a venda de 300 mil toneladas de café, 8 mil toneladas de cacau, 12 mil toneladas de erva-mate e 250 milhões de metros quadrados (sic) de madeira brasileira. A balança comercial em 1955 fecharia com os seguintes valores: produtos brasileiros importados pela Argentina, US\$100 milhões; produtos argentinos importados pelo Brasil, US\$ 152 milhões, a maior magnitude atingida até então (Cisneros \& Escude, 1999, p.111).

Não obstante, a crise interna pela qual passou o governo de Vargas foi determinante para o malogro da aproximação. Com seu suicídio em agosto de 1954, o Brasil abandonou essa diplomacia, apegando-se novamente aos Estados Unidos. Sem a parceria brasileira, o projeto de inserção internacional do peronismo retrocedeu, com o país aceitando cada vez mais as imposições de Washington, finalmente implementadas com a derrubada de Perón em setembro de 1955.

Assim, encerrava-se a primeira conjuntura de heterodoxia no campo internacional e de aproximação entre a Argentina e o Brasil.

\section{A segunda metade dos anos 1950}

Entre 1955 e 1958, a Argentina vivenciou um período ditatorial, com sua política externa valorizando a inserção do país nas instituições internacionais, como o Banco Mundial (BID) e o Fundo Monetário Internacional (FMI), e um relacionamento amistoso com os Estados Unidos. Porém, em maio de 1958, assumiu a presidência argentina Arturo Frondizi, político da União Cívica Radical Intransigente (UCRI), que apostava na união econômica com o Brasil para a retomada do crescimento de seu país. No Brasil, entrementes, Juscelino Kubitschek redirecionava sua diplomacia lançando a Operação Pan-Americana (OPA), afinando-se progressivamente com Buenos Aires. 
De início, o que era apenas uma estratégia de barganha com os Estados Unidos acabou tornando-se uma política estruturada para a aproximação efetiva das economias argentina e brasileira. As chancelarias foram se aproximando a tal ponto que, quando Jânio Quadros chegou à presidência, em 1961, essa política foi ainda mais aprofundada, permitindo o histórico Encontro de Uruguaiana. Mesmo com a renúncia de Quadros, a união desenvolveu-se no governo de João Goulart.

O Encontro de Uruguaiana ocorreu nessa cidade fronteiriça entre o Rio Grande do Sul e a província argentina de Corrientes, entre os dias 20 e 23 de abril de 1961, com a participação dos presidentes e dos respectivos chanceleres. Antes do conclave, a chancelaria argentina sugeriu ao Itamaraty o teor das discussões que seriam realizadas.

Deberá sostenerse, con toda franqueza, la necesidad de plantear sobre nuevas bases el Comercio Argentino-Brasileño. [...] El acrecentamiento de los volúmenes actuales de exportaciones y importaciones recíprocas, solo podrá ser considerado sobre la base de la apertura de ambos mercados a las producciones que signifiquen contribución a los procesos de desarrollo económico nacional en los que están empeñados los dos países. En consecuencia, deberá manifestarse con toda claridad al mandatario brasileño que el parque manufacturero paulista podrá contar con la apertura del mercado argentino, en tanto el mercado brasileño se abra para los rubros nuevos de la producción nacional de nuestro país que registren saldos exportables. Es decir: la Argentina será el mercado eventual, por ejemplo, para el material ferroviario brasileño si el Brasil orienta hacia nuestro país su política de compras en materia de petróleo y derivados, tractores o productos de la metalurgia liviana. Una vez puestas las bases de la estructura futura del intercambio podrá encarase la solución del problema del saldo que a favor de nuestro país registra la cuenta convenio. ${ }^{9}$

9 Arquivo de Frondizi. Caja 624: "Uruguaiana". Nota diplomática de 5 de abril de 1961. 
Apesar de sua pujança econômica, o Brasil apresentava déficit nessa relação comercial, o qual desejava-se ajustar por meio da multiplicação das trocas. Os argentinos sabiam que o ritmo desse comércio só poderia ser dinamizado na medida em que o planejamento bilateral predominasse, aumentando as trocas de manufaturados. A respeito dos "problemas hemisféricos", os argentinos consideravam que:

Por tratarse de problemas que afectan de manera directa a todos los países latinoamericanos y que repercuten inmediatamente en su estructura política y social, resulta inexcusable la necesidad frente a los mismos una posición que preserve de manera cuidadosa la capacidad de autodeterminación de cada país en función del interés nacional. Si Brasil y Argentina unifican criterios con relación a cada problema que se presente dentro del sistema y ofrecen, en consecuencia un frente unido, las posibilidades de solución de los mismos aumentarán correlativamente. [...] Se considera que la significación adquirida por la Argentina y el Brasil impone a ambos países la necesidad de aumentar su influencia en los grandes problemas de política internacional. (ibidem)

Se por um lado a "autodeterminação" de ambos e das demais nações vizinhas estaria fortalecida com o aprofundamento das relações, por outro os argentinos demonstravam o que eles realmente entendiam por solidariedade em relação ao entorno geográfico. A ideia de captar dinheiro público norte-americano para o subcontinente baseava-se na teoria de fazer crescer o bolo para depois dividi-lo. Isto é:

Un programa en gran escala de empréstitos públicos deberá encontrarse con prioridad en las regiones donde opere un rápido efecto promocional. En tal sentido, se considera que acelerar el desarrollo del Brasil y de la Argentina, producirá efectos muchos más rápidos en el continente que una distribución igualitaria de la ayuda norteamericana a todos los países. (ibidem) 
Também daí surgiu a assertiva de que o eixo da integração só poderia ser formado pela duas grandes nações. A explicação para essa discriminação e o respectivo privilégio para ambas era a seguinte:

El desenvolvimiento acelerado de las economías brasileña y argentina producirá efectos autónomos, que se reflejarán de manera inmediata en Uruguay, Bolivia, Paraguay, Perú, Chile, Ecuador la responsabilidad de cuyo desarrollo podrá ser parcialmente confiada entonces a los dos países más significativos de la región [...] Además la influencia de Brasil y Argentina dentro de la región podrá proyectarse sobre las naciones menores, contribuyéndose a crear una fuerte instancia sudamericana que asuma responsabilidades en la orientación de los proyectos nacionales de cada uno de esos países y en el alivio de las tensiones ocasionales que puedan producirse. (ibidem, grifo do original)

Os elogios à política de desenvolvimento do Brasil buscavam prestigiar o governo brasileiro e atraí-lo para uma aliança, ao mesmo tempo em que tomavam como exemplo para a América Latina o modelo de investimentos internos de um país muito desigual. $\mathrm{Ou}$ seja, como se pode apreciar no excerto abaixo, as regiões mais atrasadas deveriam ser estimuladas pelas mais desenvolvidas.

El esquema para América Latina puede repetir, en líneas generales, el adoptado por el gobierno de Brasil en los últimos años: concentrar la inversión nacional, publica y privada en la región capaz de alcanzar tasas de desarrollo más aceleradas (el centrosud) para posteriormente emprender los programas complementarios en el resto del país, utilizando recursos generados en el desenvolvimiento de la región a la que se acordó prioridad. (ibidem)

De alguma maneira, não obstante, foram consideradas as necessidades imediatas de certos países da região, até para evitar o descontentamento social e manter o status quo político. 
En Bolivia y en Paraguay las condiciones particularmente graves que presenta su desarrollo económico, hacen posibles tensiones sociales que repercutirán de manera negativa en la estabilidad de Argentina y Brasil. Se considera, en consecuencia, la posibilidad de estudiar una coordinación de esfuerzos, a emprender de manera urgente, tendentes a encontrar puntos de coincidencia del interés brasileño y argentino en la ejecución del programa del desarrollo de las economías paraguaya y boliviana, en aquellos sectores en que, desde ahora, Brasil y Argentina puedan colaborar de manera eficiente. Desde el punto de vista argentino la razón de urgencia actual que exigen atender las condiciones que presentan Bolivia y Paraguay es la de evitar el peligro de revoluciones sociales y de penetración comunista en el corazón del continente. (ibidem, grifo do original)

No que tange ao Tratado de Amizade e Consulta, havia muitas expectativas. Assegurou-se que ele:

a) contribuirá a la disipación definitiva resquemores y rivalidades tradicionales, hoy anacrónicos, ya que, sin perjuicio de que existan todavía intereses encontrados en determinadas regiones, los puntos de coincidencia del Brasil y de la Argentina son hoy muchos más vastos e importantes; b) instrumentará un medio ágil y positivo tendiente a aumentar la capacidad de negociación de los países. El gobierno argentino considera que esta política, rigurosamente nueva, multiplicaría la influencia de los países e indirectamente, de América Latina. (ibidem)

Para os problemas mais gerais, prometia-se:

Las bases del Tratado supondrían asimismo información y/o consulta previa sobre: a) cualquier modificación de importancia en la política exterior de Brasil o de la Argentina con referencia a problemas continentales o extracontinentales; b) gestiones comerciales de importancia ante los principales países individualmente considerados (en especial Estados Unidos de América, Unión Soviética, Japón, Gran Bretaña, Francia, Alemania). El acuerdo prevería un régimen de consulta estable y periódico en el nivel presidencial. (ibidem) 
Essas orientações políticas realmente foram cumpridas imediatamente após o encontro. A consulta mútua nas questões hemisféricas e a consideração de que os grandes problemas diplomáticos demandavam a atuação conjunta foram marcas até o golpe militar na Argentina, em 1962. No entanto, a parceria nas negociações comerciais com os países industrializados não chegou a se concretizar em nível significativo, tampouco a efetiva participação de outras nações sul-americanas nesse contexto.

Como uma espécie de pano de fundo, Frondizi, Quadros e seus respectivos chanceleres, Diógenes Taboada e Afonso Arinos de Mello e Franco, chegaram ao encontro com o intuito de também discutirem formas mais aceitáveis para os demais países do continente, sobretudo os Estados Unidos, que pudessem evitar a expulsão de Cuba da OEA. Sofrendo pressões internas dos militares, Frondizi resistia nesse assunto, naquele momento uma espécie de point d'honneur do pensamento diplomático brasileiro: a defesa da autodeterminação e da não intervenção (Bandeira, 2003, p.306).

Durante os dias de reuniões, foram progressivamente divulgadas as resoluções, sendo a primeira de caráter militar: Brasil e Argentina comprometeram-se a retirar a maioria das tropas estacionadas em suas fronteiras, decidindo criar um sistema permanente de consulta, a exemplo da esfera política. Uma autoridade do Exército brasileiro deveria ser designada para permanecer em Buenos Aires, com a missão de manter contato semanal diretamente com o gabinete presidencial e vice-versa (idem, p.308-9). Resolvido o problema militar, encaminharam-se os demais assuntos. Em 22 de abril, os dois presidentes assinaram o que se conhece como Declaração de Uruguaiana. Na íntegra, o texto contém os seguintes parágrafos:

1 - Que los Estados Unidos del Brasil y la Republica Argentina orientan y orientarán su política internacional en función de la condición sudamericana que les es común, conforme a la esencia occidental y cristiana de sus nacionalidades y de acuerdo con las responsabilidades continentales asumidas.

2 - Que ambos países están decididos a impulsar de manera activa y según los criterios determinados por su interés nacional, su partici- 
pación en la solución de los problemas internacionales que los afectan, con el propósito de contribuir a perfeccionar las buenas relaciones y el entendimiento pacífico de los pueblos.

3 - Que la preservación de las instituciones de la democracia representativa ya la consolidación de los principios de la libertad y de la dignidad de la persona humana, inherentes al origen histórico de nuestras nacionalidades, exigen con la mayor urgencia un esfuerzo de amplia envergadura para acelerar los programas de desarrollo en los países de América Latina y extirpar definitivamente los males provocados por las condiciones que afligen a la mayoría de los pueblos del continente.

4 - Que el progresivo empeoramiento de esas condiciones determina el planteo de graves problemas políticos y sociales que deben resolverse con la participación activa de los países del continente, rechazando la interferencia directa o indirecta de factores extracontinentales, respetando el principio americano de la autodeterminación de los pueblos de manera de asegurar la efectiva soberanía de las naciones y conforme a las resoluciones pertinentes adoptadas en las reuniones interamericanas.

5 - Que la defensa de la estabilidad política y social del sistema interamericano exige la concertación de una acción coordinada y conjunta que lleve a rápida ejecución los postulados de la operación panamericana, según el espíritu del Acta de Bogotá, cuyas perspectivas de realización acaban de recibir el más vigoroso apoyo en el programa "Alianza para el Progreso", propuesto por el Presidente de los Estados Unidos de América.

6- Que comparten el criterio de la colaboración económica externa sólo puede rendir frutos mediante un vigoroso esfuerzo nacional.

7 - Que, en consecuencia, debe haber todo lo necesario para aumentar los recursos nacionales, defendiendo el valor internacional de los productos básicos, luchando por la eliminación de las restricciones que cercenan las exportaciones latinoamericanas y promoviendo $e$ intensificando el comercio con todas las naciones.

8-Que los gobiernos de la Argentina y del Brasil están decididos a colaborar de manera firme y permanente en la consecución de aquellos 
objetivos que consideraban también comunes a todos los países de América Latina, para hacer de la amistad entre sus pueblos una realidad efectiva y para consolidar la paz y la democracia en todo el continente.

O documento oficial não continha assertivas revolucionárias ou concepções inovadoras para a política externa, no mais tratando de fixar os acordos e as aspirações que já estavam no horizonte diplomático das duas nações. Devido a seu caráter, a declaração não podia exacerbar o sentido reivindicativo de ambas as diplomacias, muito menos a agressividade contra os Estados Unidos. A reunião, por si só, era um gesto de insatisfação quanto à configuração das relações internacionais da região. Admitia-se pertencer ao "ocidente cristão" e comunicava-se que a diplomacia do presente e do futuro seria pautada pelo combate ao atraso industrial e à miséria correlata, objetivo de uma missão a ser desenvolvida por Brasil e Argentina, unidos e na espera da adesão dos demais países pobres do subcontinente. Evitando ao máximo o descontentamento internacional ou das classes dominantes domésticas, declaram apoiar tanto a Aliança para o Progresso quanto a Operação Pan-Americana.

A importância de tais afirmações residia no compromisso de aumentar suas trocas comerciais e coordenar decisões macroeconômicas. Na medida em que nem Frondizi e nem Quadros possuíam um quantun de poder doméstico que permitisse maior heterodoxia no campo internacional, esperava-se que a declaração, antes de iniciar uma nova realidade, fosse o reforço efetivo de um processo para potencializar os países dentro da economia e da geopolítica da época. Os vários rascunhos por nós compulsados no Arquivo Frondizi demonstram que os presidentes recuaram em muitos aspectos até chegarem à versão final a ser divulgada, ficando de fora as críticas incisivas contra os organismos financeiros internacionais, as políticas de austeridade recomendadas pelo FMI e a política de segurança anticomunista de Washington. ${ }^{10}$ Esse prudente comportamento não serviu para a aprovação do documento pelos respectivos

10 Arquivo de Frondizi. Caja 624: "Uruguaiana". Pasta "Esbozos y Minutas". 
parlamentos, dado que, com a renúncia de Quadros, o golpe militar contra Frondizi e, finalmente, com a ascensão ao poder das ditaduras, os preceitos de Uruguaiana perderam razão de ser.

Junto à declaração, conhecida como Convenção de Amizade e Consulta, veio a público o conteúdo do compromisso da aliança política, cujos parágrafos comprometiam as diplomacias de Brasil e Argentina a atuarem juntas no cenário internacional. O que os argentinos haviam proposto previamente fora aceito pelos brasileiros, embora apenas um ligeiro resumo houvesse ganhado publicidade naquele momento. Criou-se um grupo de trabalho, oficializado no início de junho, para coordenar a construção de uma hidrelétrica binacional em Sete Quedas, na região de Foz do Iguaçu, desfeita após 1964 (Lanús, 1984, p.296). A convenção fora assinada pelos chanceleres Afonso Arinos e Diógenes Taboada, prometendo ainda uma legislação para a livre circulação dos cidadãos dos dois países, a adesão de outras nações sul-americanas ao tratado, a elaboração de leis que aproximassem os poderes judiciários e o aumento do intercâmbio cultural. De forma tácita, postulava-se que, a partir de então, o processo de desenvolvimento econômico e político do subcontinente seria negociado, articulado e comandado por Brasil e Argentina (idem, p.309-10).

O presidente brasileiro propôs a formação imediata de um movimento neutralista, não só para defender Cuba, senão articular a região em moldes reivindicativos, baseados nos países africanos e asiáticos recém-independentes. Frondizi, acossado pelos militares de seu país, evitou comprometer-se nessa questão, apenas prometendo apoio ao Brasil em um futuro próximo.

Ao contrário do contexto Vargas-Perón, a união era assumida publicamente, com destaque e elogios de ambas as partes. A integração, de promessa transformava-se em compromisso, dentro de uma concepção segundo a qual, se na América do Norte quase nada se fazia sem a anuência norte-americana, na América do Sul esse papel seria assumido por uma hegemonia dual. A afirmação pela busca do neutralismo, espécie de movimento dos não alinhados comandados por brasileiros e argentinos, espelhava a confiança no 
desenrolar do processo e a força em potencial contida nessa aliança. $\mathrm{Na}$ visão dos atores envolvidos, essa parceria estava fadada a conquistar o subcontinente de modo a estabelecer uma interação de "igual para igual" com o primeiro mundo e com o bloco soviético.

Para Scenna (1975, p.357), o que ocorreu em Uruguaiana foi "[...] uno de los acuerdos más importantes suscriptos por nuestro país en su historia diplomática y aun en la esfera latinoamericana". Opinião semelhante é a de Lanús (1984, p.290): “[... se logró establecer entre ambos países un tipo de diálogo excepcional para la historia de las relaciones bilaterales". Na visão de Luna (1974, p.127), tratou-se do momento mais audacioso de toda a política externa frondizista. Para o estudioso brasileiro Bandeira (2003, p.342-3),

[...] esse processo de aproximação e coincidência, iniciado com a OPA, culminaria com os Acordos de Uruguaiana, que não só possibilitavam a formação de uma comunidade de interesses no Cone Sul, a partir de sólidas e crescentes relações bilaterais [...] contrapondo-se ao tradicional esforço dos EUA no sentido de manter a balcanização da América Latina.

Na imprensa, a repercussão foi notável. No arquivo de Arturo Frondizi encontram-se centenas de reportagens da época (chegamos a contar cerca de quatrocentas publicadas em diferentes jornais argentinos e brasileiros). Os articulistas previam um arco de possibilidades para o futuro, chegando a especular a união total, com a desaparição das fronteiras, a eleição de um governo e moeda e capital comuns. ${ }^{11}$ Como acrescenta Lanús (1984, p.292), os presidentes "[...] tenían conciencia de que estaban protagonizando un episodio excepcional en la historia de las relaciones bilaterales entre ambos Estados".

A percepção de que algo de importante e sem precedentes estava sendo realizado não foi apenas dos analistas ulteriores, senão, igualmente, de grande parte dos contemporâneos. A mídia e o público

11 Arquivo de Frondizi. Cajas 624, 629, 636 e 670. "Uruguaiana”. 
leitor tomaram conhecimento dos acordos, apoiando-os com admiração. Segundo a missão diplomática brasileira em Buenos Aires,

durante dois dias da reunião de Uruguaiana o país esteve com suas atenções voltadas para aquela cidade brasileira, esperava-se com justificada ansiedade o desfecho das conversações mantidas entre os dois Presidentes [...] Todos os jornais divulgavam com o maior destaque os textos dos documentos firmados pelos dois Chefes de Estado naquela cidade gaúcha: Declaração Conjunta, a Declaração Econômica e o Convênio Cultural. A imprensa em geral (a única exceção foi um editorial aparecido em "La Prensa" contrário a certos termos da Declaração Conjunta) recebeu favoravelmente os acordos assinados em Uruguaiana. (ibidem)

As dificuldades da economia e da política argentinas, mais graves que as brasileiras, determinaram o apego mais pronunciado desse país em relação ao que se passou no encontro. Comparando a documentação da Embaixada Brasileira em Buenos Aires e da Embaixada Argentina no Rio de Janeiro, claramente se percebe que o impacto dos acordos foi maior por lá. Aventamos a hipótese de que, para a opinião pública argentina, os tratados estavam significando o fim do sentimento incômodo e contraditório que, desde o final da Segunda Guerra Mundial, grande parte dessa sociedade cultivara em relação ao Brasil, de admiração pela pujança industrial e temor pelas alianças dos governantes brasileiros com Washington. A ameaça estava transformando-se em amizade e parceria. No entendimento de Beired (1999, p.293),

as relações de cooperação entre Brasil e Argentina assumiam, em Uruguaiana, a feição de alternativa tanto à solução revolucionária cubana para a vida política e o desenvolvimento da América Latina, quanto à solução de dominação econômica e ideológica norteamericana, no contexto da guerra fria.

No limite, delineou-se uma nova via diplomática continental, junção de aspirações nacionalistas e desenvolvimentistas, até pelo 
fato de a reunião ocorrer quatro dias após a frustrada tentativa de invasão de mercenários cubanos patrocinados pelos Estados Unidos na "Baía dos Porcos", em Cuba. A deletéria imagem que esse episódio causou aos norte-americanos alimentou a ideia de que a solução estava do lado de argentinos e brasileiros, que não faziam revoluções e pacificamente tentavam vencer o subdesenvolvimento. Ambos os presidentes também selaram um acordo para agendarem um encontro com Kennedy, em uma significativa conferência que reuniria os três líderes governamentais.

Entretanto, fatores importantes foram pesando contra a concretização dessas aspirações. O clima da guerra fria cada vez mais foi tolhendo a liberdade dos governos nos ajustes bilaterais, dado que as classes dominantes entendiam que a aproximação diplomática na região e o afastamento dos Estados Unidos denunciavam a infiltração comunista na diplomacia. Em janeiro de 1962, na VIII Conferência de Consulta dos Chanceleres Americanos, ocorrida em Punta Del Leste, no Uruguai, Argentina e Brasil opuseram-se à expulsão de Cuba da OEA, abstendo-se de votar essa resolução. Em Buenos Aires, os militares não aceitaram essa posição de Frondizi, fustigando-o até a derradeira ofensiva castrense, ocorrida em março do mesmo ano, que finalmente pôs fim ao governo radical intransigente. A vitória dos peronistas nas eleições provinciais selou a sorte dessa administração, já então periclitante.

Com a volta dos militares ao poder, a Argentina enveredou para uma política externa pró-Estados Unidos e Europa e antibrasileira, desfazendo rapidamente o que fora construído no chamado "espírito de Uruguaiana”, expressão cunhada na época e bastante utilizada na documentação diplomática para caracterizar as diretrizes unionistas. No Brasil, Goulart teve fôlego para levar a cabo a Política Externa Independente (PEI), não obstante, sem a parceria argentina, incapaz de conquistar o entorno geográfico. Com a crise de 1964 e o golpe civil-militar de março, a diplomacia brasileira afastou-se do ideário de integração, ao qual só retornou efetivamente nos anos 1980 . 


\section{Considerações finais}

As malogradas tentativas de integração nos governos de Perón e Vargas e ulteriormente de Frondizi-JK, Quadros e Goulart padeceram de impedimentos conjunturais e estruturais.

Na primeira tentativa, o subcontinente sofria uma enorme dependência dos Estados Unidos, permitindo pouca liberdade para a montagem de blocos econômicos ou políticos que contrariavam a diplomacia liberalizante de Washington. Além disso, Perón não soube trabalhar com o ritmo próprio da nova tentativa de instauração do Pacto ABC, bem como Vargas, envolto em graves contradições internas, não pode sustentar uma diplomacia brasileira de novo tipo.

No segundo lustro do decênio, Argentina e Brasil lograram a captação de capitais europeus, na medida em que esse continente completara sua reconstrução no pós-guerra. A possibilidade de barganha com os Estados Unidos aumentou, até porque os pactos de união entre os países do Velho Mundo fortaleceram ainda mais a Cepal e as diretrizes desse escopo na América do Sul. Por outro lado, a dependência de aporte de capitais externos e a presença cada vez maior das empresas multinacionais legaram aos governos a necessidade de lidar com novos fatores de poder, sobrecarregando as responsabilidades de uma política externa heterodoxa. Em outras palavras, esta se apoiava nas possibilidades de aproximação com o Leste Europeu e com os países africanos e asiáticos recémdescolonizados e em uma política econômica protecionista, voltada ao fortalecimento da indústria nacional, descontentando assim de todo o establishment internacional e os setores internos ligados à internacionalização da economia. A integração acabou dando lugar à disputa individual de cada nação pelos investimentos e pelo crescimento econômico.

Desse modo, o período aberto com as possibilidades de uma nova posição para a diplomacia do subcontinente, com a união entre suas principais nações e a elevação do protagonismo da região nas relações internacionais, acabou frustrado no início dos anos 1960. 


\section{Referências bibliográficas}

ALMEIDA, H. Sob os olhos de Perón: o Brasil de Vargas e as relações com a Argentina. Rio de Janeiro: Record, 2005.

BANDEIRA, M. Brasil, Argentina e Estados Unidos: da Tríplice Aliança ao Mercosul. Rio de Janeiro: Revan, 2003.

BEIRED, J. L. La experiencia histórica del Brasil y de la Argentina (19551964). In: LLADÓS, A. F.; TREVERTON, G. F. (Orgs.). Perspectivas: Brasil y Argentina. Buenos Aires: Cari, 1999.

BUENO, C. Política externa da Primeira República: os anos de apogeu (de 1902 a 1918). São Paulo: Paz e Terra, 2003, p.91-110.

CERVO, A.; AMADO, L.; BUENO, C. História da política exterior do Brasil. Brasília: Editora da UNB, 2002.

Política externa da Primeira República: os anos de apogeu (de 1902 a 1918). São Paulo: Paz e Terra, 2003.

CISNEROS, A.; ESCUDÉ, C. (Org.). Historia general de las relaciones exteriores de la Republica Argentina: las relaciones exteriores de la Argentina subordinada. Parte III, Tomo XI. Las Relaciones Económicas Externas (1943-1989). Buenos Aires: Grupo Editor Latinoamericano, 1999.

LANÚS, J. A. De Chapultepec al Beagle: politica exterior argentina (19451980). Buenos Aires: Emecé, 1984.

LUNA, F. Argentina: de Perón a Lanusse (1943-1973). Rio de Janeiro: Civilização Brasileira, 1974, p.127.

SANTOS, D. X. Vargas e Perón: a política externa do Brasil para a Argentina na primeira metade da década de 1950. Brasília, 1991. Dissertação (mestrado) - Unb.

SCENNA, M. Á. Argentina - Brasil: cuatro siglos de rivalidad. Buenos Aires: Ediciones La Bastilha, 1975, p.357.

\section{Fontes}

MINISTÉRIO DAS RELAÇÕES EXTERIORES, COMÉRCIO INTERNACIONAL E CULTO: Missões Diplomáticas na América do Sul, Embaixada Argentina no Brasil e "Papéis da América do Sul". ARQUIVO HISTÓRICO DO ITAMARATY: Missões Diplomáticas no Estrangeiro. Buenos Aires. Pasta de Ofícios: 1955-1960.

ARQUIVO DO MINISTÉRIO DAS RELAÇÕES EXTERIORES.

Embaixada do Brasil em Buenos Aires. Pasta de Ofícios: 1961-1964. BIBLIOTECA NACIONAL DA REPÚBLICA ARGENTINA. Arquivo Arturo Frondizi. 



\section{DADOS DOS AUTORES}

Álvaro Vázquez Mantecón. Doutor em História da Arte e professor da Universidade Autônoma Metropolitana em Azcapotzalco (México). É curador do Memorial de 1968, situado no Centro Cultural Tlatelolco da Unam. É autor de Emilio "Índio" Fernandez: mexicano mítico. México: Clío, 2000 e Dolores Del Rio. Princesa de México. México: Clío, 1999.

Áureo Busetto. Doutor em História e professor da Unesp - Assis, é autor de A democracia cristã no Brasil: princípios e práticas. São Paulo: Editora Unesp, 2002.

Carlos Alberto Sampaio Barbosa. Doutor em História e professor da Unesp - Assis é autor de A fotografia a serviço de Clio. Uma interpretação da história visual da Revolução Mexicana (1900-1940). São Paulo: Editora Unesp, 2006.

Daniel Lvovich. Doutor em História e professor da Universidade Nacional de General Sarmiento, é autor de Nacionalismo y antisemitismo en la Argentina. Buenos Aires: Vergara, 2003 e El nacionalismo de derecha en la Argentina. Buenos Aires: Claves Para Todos, 2006, e coeditor de Las políticas sociales en perspectiva histórica. Argentina. 1870-1950. Buenos Aires: UNGS, 2006.

Ernesto Bohoslavsky. Doutor em História e professor da Universidade Nacional de General Sarmiento, é autor de El compot patagónico. Nación, conspiracionismo y violencia en el sur de Argentina y Chile (siglos XIX y XX). Buenos Aires: Prometeo, 2009, e coeditor de El hilo rojo. Buenos 
Aires: Paidós, 2008 e Instituciones y formas de control social en América Latina, 1840-1940. Uma revisión. Neuquén: Universidad Nacional de la Pampa, 2006.

Francisco Luiz Corsi. Doutor em economia e professor da Unesp-Marília, é autor de Estado Novo: política externa e projeto nacional. São Paulo: Editora Unesp, 2000 e coeditor de Dimensões da crise do capitalismo global. Brasil e a crise da mundialização do capital. Londrina: Práxis, 2009.

Iuri Cavlak. Doutor em História e autor de A política externa brasileira e a Argentina peronista. São Paulo: Annablume, 2008.

José Luis Bendicho Beired. Doutor em História e professor da UNESP - Assis, é autor de Sob o signo da nova ordem. Intelectuais autoritários no Brasil e na Argentina (1914-1945). São Paulo: Loyola, 1999, Breve história da Argentina. São Paulo: Ática, 1996; e Movimento operário argentino. Das origens ao peronismo (1890-1946). São Paulo: Brasiliense, 1984.

Kátia Gerab Baggio. Doutora e docente da UFMG, é autora de A questão nacional em Porto Rico - O Partido Nacionalista (1922-1954), São Paulo: Annablume, 1998 e coautora de A rebelião de Tupac Amaru. São Paulo: Brasiliense, 1987.

Maria Valéria Galván. Mestre em Sociologia da Cultura e em História pela Universidade Nacional de La Plata. 


\author{
SOBRE O LIVRO \\ Formato: $14 \times 21 \mathrm{~cm}$ \\ Mancha: 23,7 x 42,5 paicas \\ Tipologia: Horley Old Style 10,5/14 \\ 1a edição: 2010 \\ EQUIPE DE REALIZAÇÃO \\ Coordenação Geral \\ Marcos Keith Takahashi
}




